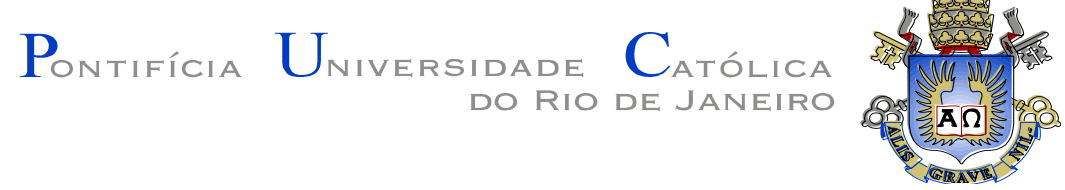

Adriana Pereira da Silva Fontes

Carmela Gross em seus territórios poéticos

Dissertação de Mestrado

Dissertação apresentada como requisito parcial para obtenção do grau de Mestre pelo Programa de Pós-Graduação em História Social da Cultura do Departamento de História do Centro de Ciências Sociais da PUC-Rio.

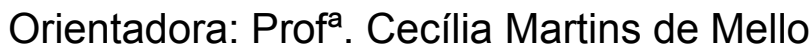

Rio de Janeiro Setembro de 2012 


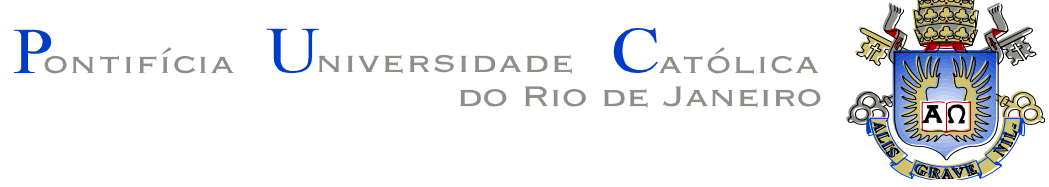

Adriana Pereira da Silva Fontes

\title{
Carmela Gross em seus territórios poéticos
}

Dissertação apresentada como requisito parcial para obtenção do grau de Mestre pelo Programa de Pós-Graduação em História Social da Cultura do Departamento de História do Centro de Ciências Sociais da PUC-Rio. Aprovada pela Comissão Examinadora abaixo assinada.

\author{
Prof ${ }^{a}$. Cecília Martins de Mello \\ Orientadora \\ Departamento de História - PUC-Rio
}

Prof. João Masao Kamita

Departamento de História - PUC-Rio

Prof ${ }^{a}$. Fabíola do Valle Zonno

Departamento de História e Teoria - FAU-UFRJ

Profa. Mônica Herz

Vice-Decana de Pós-Graduação

do Centro de Ciências Sociais - PUC-Rio

Rio de Janeiro, 12 de setembro de 2012 
Rio de Janeiro, 12 de setembro de 2012

Todos os direitos reservados. É proibida a reprodução total ou parcial do trabalho sem autorização da universidade, da autora e da orientadora.

\section{Adriana Pereira da Silva Fontes}

Graduada em Psicologia pela PUCRio em 1988, Licenciatura em Artes pelas Faculdades Integradas Bennett em 2002. Especializou-se em História da Arte e Arquitetura no Brasil pela PUC--Rio em 2006. Arte Educadora que trabalhou em diversos museus, centros culturais, escolas, projetos sociais e culturais.

Ficha Catalográfica

Fontes, Adriana Pereira da Silva

Carmela Gross em seus territórios poéticos / Adriana Pereira da Silva ; orientadora: Cecília Martins de Mello. -2012.

183 f. : il. (color.) ; $30 \mathrm{~cm}$

Dissertação (mestrado)-Pontifícia Universidade Católica do Rio de Janeiro, Departamento de História, 2012.

Inclui bibliografia

1. História - Teses. 2. História social da cultura. 3. Carmela Gross. 4. Arte e poéticas contemporâneas. 5. Centros urbanos. 6. História da arte brasileira. I. Mello, Cecília Martins de. II. Pontifícia Universidade Católica do Rio de Janeiro. Departamento de História. III. Título.

CDD: 900 
Para Daniel e Thiago 


\section{Agradecimentos}

A Cecília Martins de Mello, pela orientação precisa nos direcionamentos deste trabalho.

A Carmela Gross, pela generosidade em me fornecer imagens e catálogos e em me conceder a entrevista que foi fundamental para melhor entendimento de sua poética durante o processo de pesquisa.

A Capes e à PUC-Rio pelos auxílios concedidos a realização deste trabalho.

A Edna e a todos do Departamento de História, que me ajudaram na interlocução com a universidade durante todo o curso do mestrado. 


\section{Resumo}

Fontes, Adriana Pereira da Silva; Mello, Cecília Martins de (orientadora). Carmela Gross em seus territórios poéticos. Rio de Janeiro, 2012. 183p. Dissertação de Mestrado - Departamento de História, Pontifícia Universidade Católica do Rio de Janeiro.

Esta dissertação pretende contribuir para uma maior compreensão da poética da artista CARMELA GROSS através de uma abordagem que identifica relações plásticas, históricas e conceituais em seus territórios poéticos. Na diversidade das suas obras, a artista ativa territórios móveis, em constante definição subjetiva de um lugar poético, onde a multiplicidade simbólica desses territórios atua no espaço urbano e nos museus como jogos estéticos a serem experimentados. A artista constrói por meio de um conjunto de experiências e ações poéticas um vocabulário plástico próprio, em uma trajetória artística que revela a pesquisa constante em busca de novas descobertas no universo plástico. Do ambiente artístico da formação de Gross, em meados dos anos 1960, em São Paulo, surgiram questões que permearam suas pesquisas ao longo de seu percurso, trazendo problemáticas estéticas que instigam o experimentar e o vivenciar de um território artístico singular. Gross articula discursos [potentes e singelos] sobre a arte e a sociedade contemporânea, expandindo e contaminando tanto os ambientes dos museus [e galerias de arte] como os espaços das cidades. Portanto, a presente pesquisa teve como finalidade construir uma cartografia que contribuísse para expor a multiplicidade de olhares e reflexões, como entendimentos [provisórios], das forças que atuam na poética de Gross.

\section{Palavras-chave}

Carmela Gross; arte e poéticas contemporâneas; centros urbanos; História da Arte Brasileira. 


\section{Abstract}

Fontes, Adriana Pereira da Silva; Mello, Cecília Martins de (Advisor). Carmela Gross in her poetics territories. Rio de Janeiro, 2012. 183p. Msc. Dissertacion - Departamento de História, Pontifícia Universidade Católica do Rio de Janeiro.

This Dissertation wants to contribute to a greater understanding of the artist CARMELA GROSS poetics through an approach that identifies plastic, historical and conceptual relations in her poetics territories. On the diversity of her works, Gross active mobile territories, in constant subjective definition of a poetic place, where the multiplicity symbolic of these territories operate in urban areas and museums as aesthetic games to be experienced. The artist builds through a set of experiences and poetics actions an own plastic vocabulary, in an artistic trajectory that reveals the constant search for new discoveries in plastic universe. By the artistic environment of the Gross' formation, in the middle of 1960, in São Paulo, questions emerged and permeated her research throughout her journey, bringing aesthetic problems that instigate the undergoing and the experience of a singular artistic territory. Gross articulates discourses [potent and simple discourses] on contemporary art and society, expanding and contaminating both the environments of the museums [and art galleries] and the spaces of the cities. Therefore, the present research had as intent build a mapping which would contribute to expose the multiplicity of views and reflections as [provisional] understanding of the forces which acting in the poetics of Gross.

\section{Keywords}

Carmela Gross; art and poetics contemporary; urban areas; History of Brazilian Art. 


\section{Sumário}

1. Introdução 12

2. Capítulo I. O percurso plástico [poético] de Gross 17

2.1. O desenho 17

2.2. O pictórico poético 47

2.3. Os ambientes $\quad 55$

3. Capítulo II. Carmela Gross e o diálogo com a cidade 63

4. Capítulo III. As Escadas de Gross 108

5. Considerações finais 116

6. Referências bibliográficas 118

7. Anexo - Obras de Carmela Gross 128 


\section{Lista de figuras - Obras de Carmela Gross}

FIGURA 1 - Projeto para a construção de um céu, 1980-1981 129

FIGURA 2 - Projeto para a construção de um céu, 1980-1981 129

FIGURA 3 - Projeto para a construção de um céu, 1980-1981 130

FIGURA 4 - Nuvens, $1967 \quad 130$

FIGURA 5 - Nuvens, $1967 \quad 131$

FIGURA 6 - Us Cara Fugiu Correndo, 2000-2001 131

FIGURA 7 - Se Vende, feira de arte ARCO, Madrid, 2008

FIGURA 8 - Hotel, 2002

FIGURA 9 - Eu Sou Dolores, 2002

FIGURA 10 - Aurora, 2003

FIGURA 11 - Corpo de ideias, 1981

FIGURA 12 - Corpo de ideias, 1981

FIGURA 13 - Série Carimbos, 1977-1978 135

FIGURA 14 - Série Carimbos, 1977-1978 136

FIGURA 15 - Carimbos-linhas, 1977-1978 137

FIGURA 16 - Carimbos-pinceladas, 1977-1978 137

FIGURA 17 - Carimbos-rabiscos, 1977-1978 138

FIGURA 18 - Carimbos-manchas, 1977-1978 138

FIGURA 19 - Cartões familiares, 1975-1976 139

FIGURA 20 - Quasares, 1983

FIGURA 21 - Corpo de ideias, 1981

FIGURA 22 - Série Pintura-Desenho, 1985-1987 142

FIGURA 23 - Série Pintura-Desenho, 1985-1987 142

FIGURA 24 - Exposição Pintura-Objeto;

obra Linha-objeto, 1988

FIGURA 25 - Exposição Pintura-Objeto; obra Expansivo, 1988

FIGURA 26 - Série Pintura-Objeto; Praia, 1990 
FIGURA 27 - Série Pintura-Objeto; Trem, 1990

FIGURA 28 - Série Pintura-Objeto; Peixes, 1990

FIGURA 29 - Série Pintura-Objeto; Parte vermelha, 1990146

FIGURA 30 - Série Pintura-Objeto; Parte amarela, $1990 \quad 146$

FIGURA 31 - Série Pintura-Objeto; Parte prata, 1990

FIGURA 32 - Facas, $1994 \quad 147$

FIGURA 33 - Carne, $2006 \quad 148$

FIGURA 34 - bleu, jaune, rouge, rouge, 2004

FIGURA 35 - 28 Operações, 1999

FIGURA 36 - Feche a porta, $1997 \quad 151$

FIGURA 37 - Instalação na $20^{\text {a }}$ Bienal Internacional

de São Paulo [sem título], 1989

FIGURA 38 - Facas, 1994

FIGURA 39 - Hotel Balsa, 2003

FIGURA 40 - Hotel Balsa, 2003

FIGURA 41 - Comedor de Luz, 1999-2000 155

FIGURA 42 - Projeto Fronteiras; obra Fonte/Foz, 2001

FIGURA 43 - Cascata, 2005

FIGURA 44 - Us Cara Fugiu Correndo, 2000-2001 157

FIGURA 45 - Aurora, 2003

FIGURA 46 - Aurora, 2003 [vista do largo do Paissandu] 158

FIGURA 47 - Aurora, Bienal de Moscou, 2007

FIGURA 48 - A Negra, $1997 \quad 159$

FIGURA 49 - A Negra, $1997 \quad 160$

FIGURA 50 - Projeto Fronteiras; obra Fonte/Foz, 2001

FIGURA 51 - Cascata, 2005

FIGURA 52 - Buracos, $1994 \quad 162$

FIGURA 53 - Aurora, 2003

FIGURA 54 - Eu Sou Dolores, 2002 [vista de dentro] 163

FIGURA 55 - Carne, $2006 \quad 164$

FIGURA 56 - bleu, jaune, rouge, rouge, 2004 
FIGURA 57 - bleu, jaune, rouge, rouge, 2004

FIGURA 58 - bleu, jaune, rouge, rouge, 2004

FIGURA 59 - lluminuras, $2010 \quad 166$

FIGURA 60 - lluminuras, $2010 \quad 166$

FIGURA 61 - Hotel, 2002 [vista da cidade de São Paulo] 167

FIGURA 62 - Se Vende, feira de arte ARCO, Madrid, 2008

FIGURA 63 - Se Vende, estacionamento da

Estação Pinacoteca, São Paulo, $2010 \quad 168$

FIGURA 64 - Escada de entrada do SESC Belenzinho,

São Paulo, junho de 2012

169

FIGURA 65 em diante - Imagens fotográficas

da instalação Escadas, de Carmela Gross,

no projeto Vão do SESC Belenzinho, São Paulo,

realizadas pela autora em junho de 2012 


\section{1 Introdução}

Pretendeu-se com este estudo acompanhar o percurso artístico de Carmela Gross através de um mapeamento do seu território poético. Diante das problemáticas que surgem no contato com a obra, corre-se o risco de aprisionar sua poética submetendo-a a uma análise interpretativa, vertical, de uma perspectiva a priori. A intenção de mapear o território poético da artista busca captar, entrar em contato com a obra da artista em sua exterioridade e extensão, constituídas de fluxos e bloqueios, em uma dimensão horizontal. $\mathrm{O}$ desenho do mapa pode ser entendido como experimentação que revela as problemáticas em desenvolvimento, sem o esgotamento das questões. Nesse sentido, a tarefa deste estudo é contribuir para o entendimento de que as problemáticas apresentadas durante o percurso artístico de Carmela não buscam capturar sentidos por meio de uma interpretação, mas destacar pontos importantes dessa cartografia, no intuito de explorar a Obra de Carmela Gross em seus deslocamentos poéticos.

Os caminhos de leitura da poética de Gross traçam linhas que não nascem de um mesmo ponto, são caminhos plásticos que se deslocam em variadas direções, se afastam, se cruzam, se desdobram e se fecham em uma cartografia sem hierarquia cronológica, plástica ou conceitual, que deflagra percursos rizomáticos na geografia de seu universo estético. O mapeamento das linhas plásticas, conceituais, do território poético de Carmela Gross é determinado a partir de diálogos com algumas de suas obras. Deleuze e Guattari vão buscar na botânica o termo rizoma para traduzir o conceito de multiplicidade, muito mais próximo da nossa forma de pensar e adquirir conhecimento, visto que o fundamento do rizoma é a própria multiplicidade. Portanto, na presente pesquisa pretendeu-se abordar a obra de Carmela Gross segundo o princípio da cartografia de Deleuze e Guattari, na qual um rizoma, por não 
responder a nenhum modelo estrutural ${ }^{1}$, age em oposição aos sistemas em árvore que funcionam por decalque da realidade. O rizoma funciona como um mapa. Se o mapa se opõe ao decalque, é precisamente porque está totalmente orientado para uma experimentação que atua sobre o real. O mapa não reproduz um inconsciente fechado sobre si mesmo, ele o constrói. E nesse sentido a pesquisa teve como intenção tratar da obra da artista a partir dessa noção de mapa que é aberto, conectável em todas as suas dimensões, desmontável, alterável, suscetível de receber, constantemente, modificações. Um mapa que, segundo os autores, pode ser rompido, alterado, adaptar-se a montagens distintas, iniciado por um indivíduo, um grupo, ou ainda uma formação social. Uma das características mais importantes do rizoma talvez seja a de ter sempre múltiplas entradas. Nas palavras dos autores:

O mapa é aberto, é conectável em todas as suas dimensões, desmontável, reversível, suscetível de receber modificações constantemente. Ele pode ser rasgado, revertido, adaptar-se a montagens de qualquer natureza, ser preparado por um indivíduo, um grupo, uma formação social. Pode-se desenhá-lo numa parede, concebê-lo como obra de arte, construí-lo como uma ação política ou como uma meditação. ${ }^{2}$

Sendo assim, os traçados do mapa poético de Carmela Gross apresentam alguns eixos temáticos que são analisados em capítulos distintos, criando linhas cartográficas, com conexões entre si, como redes de comunicações rizomáticas, sem limites de extensão, relações de hierarquia, de sentido, decalque, síntese ou cronologia entre seus pontos de conexão, dispostos horizontalmente no mapa de seu território artístico. O objetivo desta proposta de pesquisa é explorar um pensar sistêmico, um pensar que cria e costura relações, gerando um conhecimento que explora a multiplicidade, a complexidade de uma poética contemporânea que se expande para além da informação ou análise.

\footnotetext{
${ }^{1}$ Um rizoma está alheio a toda ideia de eixo genético, como também de estrutura profunda em oposição aos sistemas em árvore, que funcionam por decalque da realidade, e limitam-se a descrever algo que se dá por feito. De forma distinta, o rizoma funciona como um mapa. Um rizoma pode ser rompido, interrompido em qualquer parte, mas sempre recomeça segundo esta ou aquela das suas linhas, e ainda segundo outras. Nas palavras dos autores: "Qualquer ponto do rizoma pode ser conectado com qualquer outro e deve sê-lo. Isso não sucede com a árvore nem com a raiz, que sempre se fixam a um ponto, uma ordem". DELEUZE, Gilles; GUATTARI, Félix. Mil platôs. São Paulo: Editora 34, 2007, vol. 1, pág. 15.

${ }^{2}$ DELEUZE, Gilles; GUATTARI, Félix. Mil platôs. São Paulo: Editora 34, 2007, vol. 1, pág. 22.
} 
Para a realização dessa proposta de pesquisa, a presente dissertação foi dividida em três capítulos. Em um primeiro momento, foi acompanhado o percurso plástico poético de Carmela Gross não a partir de uma leitura cronológica, mas através de eixos conceituais que surgiram a partir das obras da artista: o desenho, as questões pictóricas e os ambientes. Com esses eixos, foram traçadas linhas de pesquisa que relacionaram algumas de suas obras às problemáticas da arte contemporânea e ao ambiente artístico da formação da artista, em São Paulo, em meados dos anos 1960. A poética de Gross em seus desenhos, pinturas e ambientes estabelece diferentes diálogos com o espectador, com a arquitetura, com o sistema da arte e com as cidades, ampliando os sentidos perceptivos, simbólicos, ativando uma experiência estética singular a cada trabalho. Assim, a artista constrói por meio de um conjunto de experiências e ações poéticas um vocabulário plástico próprio, em uma trajetória artística que gera múltiplos agenciamentos estéticos e políticos. A maestria com que Carmela Gross ativa sua poesia no espaço é elaborada através de uma linguagem plástica que se inicia em experimentações com o desenho e com a escultura, em meados dos anos 1960 e na década de 1970, e segue em um percurso singular de pesquisa plástica com o desenho, no qual incorpora questões da pintura em suas pinturas-objetos, depois explora instalações em ambientes e intervenções nas cidades. A partir dos anos 2000 inicia sua pesquisa plástica com lâmpadas e letras luminosas, com a qual atinge uma síntese poética que revela toda a amplitude dessa pesquisa.

$\mathrm{Na}$ formação de um artista sempre há um ambiente que promove variadas instâncias de um saber artístico, que é incorporado à poética de cada artista. $\mathrm{O}$ presente estudo não pretendeu estabelecer uma relação direta de influências e referências artísticas que tenham formado a poética de Carmela Gross. Entretanto, houve o desejo de mapear experiências de artistas que dialogaram com as mesmas problemáticas estéticas e conceituais no período em que se dá a formação da artista. Gross, na segunda metade dos anos 1960 [em São Paulo], estudava na FAAP, onde havia um ambiente de inquietações e experimentações entre professores, artistas e alunos de arte, que viviam uma época de coletividade. E, ao compartilhar esse ambiente artístico, seus ideais comuns se uniam em busca da liberdade de explorar e experimentar linguagens, materiais, conceitos, incentivando novas práticas artísticas, 
novos modos de pensar o sistema da arte e o mundo. Todo esse ambiente de que a artista participou em sua formação [nos anos 1960-1970 em São Paulo] estimulou questões e conceitos que foram sendo explorados em muitas de suas obras posteriores. Apesar dessas experiências iniciais de Gross terem sido fundamentais para o que se desdobrou como um modo particular de experimentar, e criar, em sua poética, o percurso artístico de Gross não deve ser limitado por uma análise linear, cronológica. As contaminações poéticas desse ambiente, como as problemáticas de outros artistas, são referências que moldaram sua obra em um fluxo de absorção e pesquisa, no qual questões plástico-poéticas latentes surgem e desaparecem por todo o seu percurso. Portanto, a presente pesquisa destacou importantes diálogos que atravessam seu caminho, e que sugerem uma contaminação poética no desenvolvimento de sua pesquisa, estabelecendo relações com algumas de suas obras, desde o início como estudante da FAAP até hoje em dia.

No momento seguinte, no capítulo II, buscou-se analisar os diálogos de Gross com as cidades contemporâneas onde realizou obras site specific provisórias e permanentes. Na metrópole contemporânea, onde cada vez mais somos bombardeados por imagens e palavras sobrepostas ininterruptamente, em uma sequência sem fim e sem sentido, intermediadas por telões e luzes, Gross traz, em suas obras, uma dimensão poética crítica, utilizando o mesmo aparato tecnológico. Desse modo, a artista problematiza a vivência urbana através de jogos poéticos, sensoriais, que aproximam o sentir e o praticar simbólico da linguagem das cidades contemporâneas, ampliando seus sentidos críticos, perceptivos e metafóricos. A poética de Gross na cidade propõe uma interação perceptiva, muitas vezes crítica, não somente através de palavras ou luzes de neon, mas a partir de imagens, signos poéticos ou representações da cidade como fluxos móveis, que estabelecem novas relações de sentido, ampliando percepções e/ou reflexões, dependendo do contexto em que é instalada. Na amplitude de sua poética, as obras de Gross promovem diferentes experiências nas cidades, ora geram instâncias de reflexão, em outras, uma intensa experiência sensorial, fenomenológica, ou mesmo uma silenciosa integração da obra na vivência do espectador/passante com a cidade. Entretanto, todas estabelecem relações plásticas com o ambiente, integrando sua poética em uma 
territorialidade móvel, que instigam agenciamentos de sentidos e representações simbólicas. Ou seja, a partir de suas obras nas cidades podem surgir ressignificações tanto no campo artístico, estético, como no espaço urbano de convivência. Gross propõe no espaço-tempo [fugaz] das metrópoles um jogo poético como uma nova experiência de cidade. Seja essa experiência ativada, ou não, pelo diálogo estético, sempre haverá uma provocação que propõe um novo olhar, um novo vivenciar da cidade, em fluxos poéticos, a cada obra.

Em seguida, no capítulo III, no sentido de promover uma investigação sobre questões pertinentes à poética da artista, escolheu-se, a partir de uma obra atual, Escadas, trazer diversas problemáticas exploradas no mapa poético da artista através de texto e imagens. Assim, a partir dessa obra, em uma relação rizomática com a cartografia poética da artista, foi possível estabelecer conexões sem limites de extensão e relações de hierarquia, para ser analisada em seus contextos espaciais, conceituais e ideológicos.

Em um último momento optou-se por uma breve consideração final da dissertação, na qual se destacou a costura de relações de sentido feita a cada obra, cada território poético, como entendimentos provisórios de relações poéticas [plásticas e conceituais] das forças que atuam entre situações, contextos históricos e elementos aparentemente isolados. Entretanto, na pluralidade de sua poética é visível um sistema interligado, uma cartografia poética, em que o elo é a Obra de Carmela Gross. 


\section{2}

\section{Capítulo I. O percurso plástico [poético] de Gross}

Em suas esculturas, pinturas, desenhos, impressões, instalações e intervenções urbanas, Carmela Gross experimenta e explora questões que se voltam para a imagem, o ambiente, o espaço urbano e o próprio sistema da arte. Embora exista uma multiplicidade de meios e materiais na poética de Gross, permanece um vocabulário artístico singular através de uma pesquisa constante. Na sua trajetória artística há momentos em que Gross problematiza questões formais do desenho, em outros, da pintura, do ambiente, sempre propondo uma nova experiência, um novo modo de olhar, pensar, sentir. A artista constrói sua poética por meio de uma intensa pesquisa plástica, que dialoga com o contexto histórico das vanguardas dos anos 1960, em seus objetos, materiais, dimensões, ambientes e intervenções, que envolvem o espectador em uma experiência estética diferente a cada nova ideia, nova obra, ao longo de seu percurso artístico.

\section{1}

\section{0 desenho}

A poética ativada pelos desenhos de Gross convida o espectador a experimentar, a ampliar seus sentidos, e investigar o trabalho a partir de múltiplas relações que se moldam no espaço. Essas relações se estabelecem devido à força de uma [materialidade] poética que explora todo um universo sensorial, fenomenológico, plástico, formal e conceitual. Essas múltiplas relações podem ser percebidas na obra de Gross Projeto para a construção de um céu [Figuras 1, 2 e 3], que se constitui em 33 imagens de céus, coloridos a lápis sobre papel, em pranchas diagramadas com os códigos visuais da construção arquitetônica. A artista, com a 
técnica do lápis de cor, constrói volumes, cores e formas, em sua interpretação de um céu real-imaginário, provocando no espectador a vivência de inúmeros estados do fenômeno celeste. Carmela Gross, nesse trabalho, parece buscar a dimensão fenomenal do mundo sensível, e da mancha pictórica, em uma reverberação luminosa de luz colorida, e sombra, sem limites definidos, envolvendo na totalidade de suas imagens toda a extensão da parede do espaço expositivo, do quase chão ao quase teto. As imagens expostas lado a lado na parede da sala expositiva instigam no espectador a experiência de que sua visão pode quase tocar o céu. E, nesse caminhar poético, a visão quase toca a fantasia, materializando o desenho na imaginação, que, ativado pela profundidade perspectivada, conduz o espectador a um mergulho imaginário no céu e nas construções celestes de Gross.

Entretanto, apesar de sensorialmente o espectador ser invadido por imagens oníricas de um céu poético, a artista também inclui a linguagem de uma convenção gráfica utilizada no desenho da arquitetura. Desse modo, ao mesmo tempo em que participa de uma experiência gerada e vivida no sentir poético-visual, a artista propõe ao espectador, em uma mesma operação, investigar diferentes modos de representação do desenho. Nessa obra a artista explora, em suas 33 diferentes visões de céus, diversas questões do desenho; desde o desenho de observação e seus diferentes modos de representação, como a representação de um céu através de convenções visuais como o desenho de uma carta celeste, ou de um processo de construção arquitetônico. Assim, a obra lança, a partir do desenhar, perguntas sobre o medium do desenho, ou seja, a partir do mesmo meio [do desenho] Gross convida o espectador a participar de uma experiência estética que envolve problemáticas do desenho.

Ivo Mesquita comenta que, para ele, o Projeto para a construção de um céu aborda no mesmo trabalho a questão da representação e a questão pictórica [as nuvens e o céu na paisagem], narrando seu movimento como transitório, efêmero. Desse modo, alude a questões e a temas da história da arte, como a representação, a pintura, a natureza e o tempo. O Projeto para a construção de um céu, para Ivo 
Mesquita, é uma "passagem do plano da representação para a materialização de uma presença real do espaço, transformadora da percepção"3.

E é nesse sentido que a força poética do desenho se materializa ativando uma corporeidade, que também pode ser percebida em outras experiências que a artista propõe. Mesquita comenta a questão do desenho na obra de Gross:

É com "Projeto para a construção de um céu" que a artista afirma a questão do desenho como fio condutor de seu trabalho, como base conceitual para qualquer projeto e como referência primeira para o pensamento sobre a arte e a prática artística. Trata-se de um trabalho afirmativo, extenso, consistente, uma dissertação - papel que ele realmente teve na vida acadêmica da artista. ${ }^{4}$

Essa série de desenhos do Projeto para a construção de um céu foi realizada em uma pesquisa teórico-prática para a Escola de Comunicações e Artes da Universidade de São Paulo (ECA-USP) em 1980-1981, para obtenção do grau de mestre. Gross comenta que tinha os princípios norteadores do projeto, e, aos poucos, foi desenvolvendo a questão central da dissertação, que era sobre o desenho e seus vários modos de representação. Como não havia uma teoria que direcionasse a pesquisa, o projeto foi nascendo ao longo do processo experimental do desenhar, do pensar, e do escrever. Desse modo, a teoria para sua dissertação de mestrado foi sendo gerada a partir de uma pesquisa experimental com as variadas maneiras de "anotações" do desenho. As questões que surgiam das experiências com o desenho foram levando a artista a elaborar conceitos, teorias, para abordar as particulares "anotações" que ela fazia ao longo do processo de trabalho. A artista, no Projeto para a construção de um céu, elabora em cada prancha, ao mesmo tempo, as diferentes anotações do desenho; o de observação de nuvens, o desenho da projeção ortogonal da arquitetura, o da malha ortogonal [embaixo do desenho] de um desenho topográfico, e o desenho da "carta celeste". Gross comenta essa obra: "Então, tem o

\footnotetext{
${ }^{3}$ Entrevista com Ivo Mesquita. Catálogo da exposição Carmela Gross, um corpo de ideias. Curadoria e texto de Ivo Mesquita. São Paulo: Pinacoteca do Estado, 2010, pág. 23.

${ }^{4}$ Entrevista com Ivo Mesquita. Catálogo da exposição Carmela Gross, um corpo de ideias. Curadoria e texto de Ivo Mesquita. São Paulo: Pinacoteca do Estado, 2010, pág. 23.
} 
céu das estrelas, o céu topográfico, o céu de observação e o céu de arquitetura, porque aquilo se configura como um projeto arquitetônico",5.

$\mathrm{Na}$ experiência com as cartas celestes, a artista fragmenta o desenho da carta celeste do hemisfério sul, dividindo-o em 33 pedaços, nos quais em cada desenho de seu Projeto para a construção de um céu há um fragmento do hemisfério sul. Portanto, na união de todos aqueles desenhos é possível reconstituir a carta celeste, de uma visibilidade do céu e das estrelas nebulosas do hemisfério sul, como um outro olhar, e, consequentemente, um outro desenho do céu. Um desenho investigativo que, ao navegar pelas brumas da fantasia através de uma carta celeste, indica as diversas formas possíveis de navegação em um real imaginado, que o desenho de observação pode proporcionar. Carla Zaccagnini ressalta que, tanto o título como os meios de representação do Projeto para a construção de um céu fazem parte do repertório do desenho técnico, arquitetônico:

[...] linhas verticais e horizontais em intervalos regulares e notações em nanquim no pé da página remetem a esses desenhos cuja função é garantir uma leitura inequívoca, com instruções mais que as palavras, de forma a dirigir a construção ou a montagem de uma estrutura assegurando o resultado previsto. ${ }^{6}$

Entretanto, Zaccagnini comenta que ao mesmo tempo que existe o desenho de projeto dentro desse modelo de construção, nas áreas preenchidas com lápis de cor surge um outro tipo de desenho, que remete aos das crianças. Sendo assim, haveria no Projeto para a construção de um céu uma relação antagônica entre essas duas linguagens de desenho, pela qual o técnico é icônico e o infantil, metonímico. Para a autora, na linguagem da criança há a busca do reconhecer e representar no desenho a experiência, o algo já visto, enquanto no projeto de desenho técnico o intuito é representar o que será inventado, construído a partir de uma ideia, em que o desenho é a ferramenta inaugural. Com suas palavras:

\footnotetext{
${ }^{5}$ Entrevista com Carmela Gross concedida à autora. São Paulo, 13 de outubro de 2011, no ateliê da autora.

${ }^{6}$ ZACCAGNINI, Carla. Desenhos, desenhos: a título de prólogo. Catálogo da exposição Carmela Gross, um corpo de ideias. Curadoria e texto de Ivo Mesquita. São Paulo: Pinacoteca do Estado, 2010, pág. 97.
} 
O desenho técnico se aproxima daquilo que quer retratar mediante abreviações e sínteses inconfundíveis, que derivarão necessariamente numa consequência dada, ou melhor, preconcebida. O desenho infantil generaliza, não retrata este ou aquele indivíduo específico e sim um grupo, uma espécie, um conjunto de indivíduos sob o mesmo nome, pondo foco em um detalhe que o caracteriza como símbolo: a boca enorme e cheia de dentes do jacaré, a casa espiralada às costas do caracol, o cocar na cabeça do índio. ${ }^{7}$

O desenho infantil que generaliza ou recorta a forma que simbolicamente leva à compreensão rápida é explorado por Gross em Nuvens [Figuras 4 e 5], uma obra de 1967, que é constituída por seis peças de madeira recortada como um desenhoescultura de nuvem, em escala ambiental. Nessa obra, a matéria poética se corporifica em uma construção projetada, em módulos de peças recortados artesanalmente em madeira, que, apesar de serem de tamanhos diferentes, mantêm um padrão formal ondular na parte de cima e se mantêm em pé por uma base ortogonal ao chão. Cada peça parece ser recortada como um desenho em papel, mas de um material rígido, em que as partes, ao serem destacadas e coladas lado a lado, se unem criando um aspecto sólido. As peças formam um conjunto de nuvens azuis que parecem se materializar como parte de uma fábula, uma história em quadrinhos, mesmo um objeto cenográfico para um espetáculo infantil. Gross parece utilizar em Nuvens estratégias de construção para moldar o impalpável. Desse modo, seu desenho, que corporifica o universo infantil e dos quadrinhos, se "torna" objeto que, ao se relacionar entre os vários módulos de nuvens no espaço expositivo, evoca elementos cenográficos de uma peça de teatro infantil. Segundo Ivo Mesquita, o desenho das nuvens se apresenta como um projeto; "a representação como uma construção, uma narrativa, portanto uma forma de ficção"

A relação que as Nuvens de Gross estabelecem no ambiente sem dúvida remete a diversas narrativas e possibilidades de conexões poéticas. E dentre essa e outras conexões é notória a presença dos dispositivos estéticos da cultura industrializada na pintura de esmalte sintético, das peças de módulos do mesmo formato [com tamanhos

\footnotetext{
${ }^{7}$ ZACCAGNINI, Carla. Desenhos, desenhos: a título de prólogo. Catálogo da exposição Carmela Gross, um corpo de ideias. Curadoria e texto de Ivo Mesquita. São Paulo: Pinacoteca do Estado, 2010, pág. 97.

${ }^{8}$ Entrevista com Ivo Mesquita. Catálogo da exposição Carmela Gross, um corpo de ideias. Curadoria e texto de Ivo Mesquita. São Paulo: Pinacoteca do Estado, 2010, pág. 23.
} 
diferentes] que revelam o desenho de fácil execução e comunicação. Esses aspectos que se destacam nas Nuvens de Gross estão presentes na discussão do universo artístico que surgia naquele momento histórico com as problemáticas tratadas na Arte Pop. As Nuvens de Gross fazem parte de uma construção projetada como se fossem diversos módulos industrializados, de diferentes tamanhos e formas. Contudo, mesmo remetendo a um cenário construído industrialmente, como objetos produzidos em massa, estes são módulos de peças recortados artesanalmente em madeira [eucatex] e serem pintados com tinta esmalte [a qual produzia um aspecto industrializado]. E apesar de serem dispositivos poéticos que tratam da questão da industrialização e sua produção indiferenciada, padronizada, direcionada a um consumo massificado, banal, ao ser construída artesanalmente propõe uma ambiguidade. Através de recortes de madeira colados lado a lado, como a montagem de um jogo infantil, a artista cria um elo poético entre o fazer artesanal e o industrial. Em Nuvens surge a possibilidade de uma nuvem fabricada, que encosta no chão, trazendo o padrão banal, repetitivo dos módulos pré-fabricados, feitos para serem repetidos sem alterações, na cor esmaltada, resgatar o artesanal escondido na matéria das peças feitas em madeira, que encontra na poesia da diferença dos diferentes formatos e tamanhos dos módulos e no traçado do desenho de quadrinhos o toque individual, personificado de uma ideia. Assim, Gross constrói sua narrativa plástica deslocando o signo visual dos quadrinhos, para serem corporificados em escala ambiental, como objetos que ativam a imaginação, os sonhos e a criação da obra por parte de um espectador envolvido.

A poética plástica de Gross, nessa obra, com seus recortes de nuvens cobertas por um material industrial na cor azul de esmaltes sintéticos, remete a um azul da linguagem do desenho infantil e a um traçado dos balloons, do universo dos quadrinhos, materializado em forma de escultura de nuvens. Nesse sentido, as Nuvens de Gross estabelecem um diálogo com as vanguardas dos anos 1960, e com o debate da "Nova Figuração", que se dá no Brasil em final dos anos 1960. Na passagem dos anos 1950 para a década de 1960 essa problemática da pintura, que se volta para a questão da figuração, fica evidente no panorama mundial das artes plásticas. Desse modo se desloca o eixo da arte, de uma experiência construtiva, que até então era dominante no circuito artístico da contemporaneidade brasileira, para uma pesquisa 
da representação da imagem. Assim, nessa pesquisa, a imagem é explorada através de um vocabulário de linguagem [pop] de fácil e rápido acesso. E ao utilizar recursos da comunicação de massa, atuam como potência crítica [e política]. Em 1967, ano em que foram realizadas as Nuvens, a Arte Pop no Brasil estava em destaque entre os jovens artistas devido à recente apresentação de obras dos artistas norte-americanos na IX Bienal de São Paulo. Ali estavam presentes as obras Três bandeiras, de Jaspers Johns, o Quarto de Dormir, de Claes Oldenburg, o Posto de Gasolina, de George Segal, e a grafia de Roy Lichtenstein.

Ronaldo Brito comenta ${ }^{9}$ que a existência de uma Arte Pop brasileira era questionável, devido ao fato de que a nossa pop não tinha o mesmo conteúdo cético da norte-americana. Diz Brito:

O nosso "momento" pop não trazia o conteúdo cético, não exibia a cicatriz aberta do eu-lírico moderno, um estágio inédito de indiferença, o típico desencanto pop. Não exibia enfim um sorriso ambíguo, sábio e hipócrita, diante daquilo em que se transformara um século de heroica arte moderna - mercadorias e mais mercadorias. ${ }^{10}$

O autor acredita que a Arte Pop no Brasil surgiu como um ponto de ruptura das ideologias construtivas, trazendo uma euforia crítica na arte que finalmente iria dialogar com o mundo, onde o comum e o cotidiano seriam seu vocabulário. Em outras manifestações artísticas, Brito destaca uma euforia ingênua dos artistas ao encontrar o Belo nos outdoors e nos quadrinhos, explorando um lirismo possível na linguagem da mercadoria, como um "otimismo crítico"11. E acrescenta: "Simplificando um pouco, poderíamos dizer que nossa pop, herdeira em muitos sentidos dos construtivismos, carregava ainda uma positividade, uma inabalável boa vontade moderna"12. Antônio Dias, segundo o autor, apesar de trabalhar com as narrativas que nos remetem ao universo dos quadrinhos, revela com sua

\footnotetext{
${ }^{9}$ BRITO, Ronaldo. Brasil: boa-fé moderna. In: LIMA, Sueli de (Org.), Experiência crítica - textos selecionados: Ronaldo Brito. São Paulo: Cosac Naify, 2005, págs. 131-134.

${ }^{10}$ BRITO, Ronaldo. Brasil: boa-fé moderna. In: LIMA, Sueli de (Org.), Experiência crítica - textos selecionados: Ronaldo Brito. São Paulo: Cosac Naify, 2005, pág. 131.

${ }^{11}$ BRITO, Ronaldo. Brasil: boa-fé moderna. In: LIMA, Sueli de (Org.), Experiência crítica - textos selecionados: Ronaldo Brito. São Paulo: Cosac Naify, 2005, pág. 132.

${ }^{12}$ BRITO, Ronaldo. Brasil: boa-fé moderna. In: LIMA, Sueli de (Org.), Experiência crítica - textos selecionados: Ronaldo Brito. São Paulo: Cosac Naify, 2005, pág. 134.
} 
expressividade visceral uma negação à $P o p$, e se afasta ainda mais com sua diagramação neoconcreta do espaço. Sendo assim, nesse momento os artistas brasileiros, ao explorarem e pesquisarem em seus trabalhos essas potências plásticas, mesclam essas estéticas na singularidade de suas poéticas. Paulo Reis complementa com sua análise da época:

Não havia apenas uma discussão única de figuração, mas várias linguagens figurativas, e a abstração geométrica já havia sofrido uma série de transformações desde os primeiros trabalhos mostrados pelos grupo Frente e Ruptura no início dos anos $1950 .{ }^{13}$

Nesse contexto, ao se referir aos movimentos que a partir de 1960 reintroduziram no campo artístico brasileiro a representação icônica, Daisy Peccinini considera que, o que na época foi chamado de "Nova Figuração", foi um "leque muito amplo de propostas e ações" ${ }^{14}$ e que não se limitou a uma única tendência. A autora acredita que a tendência mais decisiva foi a Arte Pop, porém, como não foi a única manifestação vinculada à imagem nesse período, destaca que havia "duas polaridades significativas". A primeira seriam as diferentes tendências que dialogam com matrizes surrealistas e dadaístas como o "Realismo Mágico" e a "Figuração Fantástica", e a segunda seriam os "movimentos autônomos neofigurativos"15 como a Arte Pop norte-americana, o Nouveau Réalisme, a Nouvelle Figuration na França e a Nuova Figurazione na Itália ${ }^{16}$.

Paulo Sérgio Duarte comenta que, em uma leitura desse período da arte brasileira, poderiam ser percebidas semelhanças com a produção estrangeira por "olhares leigos e embrutecidos pelo cotidiano agitado da vida urbana"17. O autor

\footnotetext{
${ }^{13}$ REIS, Paulo Roberto de Oliveira. Exposições de arte - Vanguarda e política entre os anos 1965 e 1970. Curitiba: Editora UFPR, 2005, pág. 75.

${ }^{14}$ ALVARADO, Daisy Valle Machado Peccinini de. Figurações Brasil anos 1960: neofigurações fantásticas e neossurrealismo, novo realismo e nova objetividade. São Paulo: Itaú Cultural; Edusp, 1999.

15 ALVARADO, Daisy Valle Machado Peccinini de. Figurações Brasil anos 1960: neofigurações fantásticas e neossurrealismo, novo realismo e nova objetividade. São Paulo: Itaú Cultural; Edusp, 1999, pág. 14.

${ }^{16}$ Daisy Valle Machado Peccinini de Alvarado considera que esse diálogo dos artistas brasileiros, com os movimentos neofigurativos internacionais, deu-se em um momento de intensa movimentação político-social na ditadura militar, que se instala no país em 1964.

${ }^{17}$ DUARTE, Paulo Sérgio. Anos 1960: Transformações da arte no Brasil. Rio de Janeiro: Campos Gerais, 1998, pág. 14.
} 
esclarece que, mesmo que possam passar despercebidas, existiriam diferenças na arte brasileira dessa época "que lhe dão um caráter próprio":

De um lado, estaria o retorno à figuração habitada por ícones da sociedade industrial, sejam tipos humanos, cenas, ou mercadorias. De outro estariam trabalhos que desdobrariam as experiências construtivas dos anos 50 - particularmente o concretismo e o neoconcretismo junto a outras que rompem e inauguram novos campos com intervenções mais radicais sobre o ambiente e com o engajamento do corpo. ${ }^{18}$

Havia, de fato, esses dois grupos diferentes: o retorno à figuração e os desdobramentos das experiências construtivas. Contudo, mesmo sendo configurados dois grupos, esses tinham suas complexidades, de modo que não poderiam ser classificados apenas por duas correntes separadas, distintas e fechadas conceitualmente, havia diferenças importantes a serem destacadas. Essas diferenças, segundo Paulo Sérgio Duarte, teriam sido estimuladas por antecedentes históricos que criaram características próprias, as quais se desdobraram em diversas propostas e experimentações desse período. Para o autor as ideias básicas que geraram essas transformações na arte brasileira eram comuns aos dois grupos. Ou seja, a influência das ideias de Oswald de Andrade [e seu manifesto antropofágico] teria estimulado os dois grupos em seus diferentes contextos estéticos. Essas ideias seriam originárias do movimento modernista, porém essa influência teria se dado mais no sentido da contaminação das ideias de Oswald de Andrade no movimento do que sua expressão plástica, que, segundo Duarte, era tímida e envergonhada "como quem sai da casa-grande para a cidade e não quer mostrar - aliás, com justa razão - seu passado recente escravocrata e ignorante" ${ }^{\prime 19}$. Duarte acredita que essas ideias de Oswald, na época de Semana de 1922, não encontraram um correspondente na produção plástica, que ainda estava em um lento trabalho de assimilação da forma moderna. Em contraponto, o ambiente inquieto e insatisfeito com o sistema e a prática da arte brasileira nos anos 1960 era receptivo a essas ideias de Oswald, e portanto teria reativado e se apropriado desse pensamento antropofágico.

\footnotetext{
18 DUARTE, Paulo Sérgio. Anos 1960: Transformações da arte no Brasil. Rio de Janeiro: Campos Gerais, 1998, pág. 14.

${ }^{19}$ DUARTE, Paulo Sérgio. Anos 1960: Transformações da arte no Brasil. Rio de Janeiro: Campos Gerais, 1998, pág. 14.
} 
Esse ambiente inquieto dos anos 1960 se deixa contaminar pelas ideias antropofágicas, que fomentavam a não passividade diante das referências externas [artistas ou não], incentivando e legitimando uma pesquisa autoral, experimental, indo ao encontro das aspirações, inquietações e manifestações da vanguarda brasileira a partir da década de 1960. Para Duarte, o outro momento histórico que teria influenciado esse período experimental foi a produção nos anos 1950, iniciada no campo arquitetônico, depois na música e nas artes plásticas, com o manifesto Neoconcreto em 1959. O manifesto e o neoconcretismo não poderiam ser considerados, para o autor, apenas como uma ruptura com a produção concreta de São Paulo, mas como uma mudança de tom. Nas palavras de Duarte:

[...] uma mudança de tom que confronta e corrige conceitualmente as visões importadas. [...] é sobre esse terreno, no final dos anos 1950 e início dos anos 1960, que irão germinar as transformações da arte brasileira que se desdobravam tanto na nova figuração, quanto em experiências pós-construtivas diretamente tributárias desse passado recente. ${ }^{20}$

Duarte adverte que é preciso compreender as fortes diferenças entre a Arte Pop e a Nova Figuração brasileira. Citando suas palavras:

[...] o território simbólico explorado pelos artistas no Brasil tem fronteiras próprias. Este continente e seu relevo sugerem uma nova configuração da obra de arte, diferente daquela importada dos grandes centros do hemisfério norte. Durante muito tempo assisti a certos raciocínios fáceis como a aproximação entre a Nova Figuração no Brasil e a Pop Art norte-americana. Por isso me preocupei em diversas passagens em estabelecer as diferenças e demonstrar a autonomia da produção dos artistas brasileiros em relação a seus vizinhos do norte. ${ }^{21}$

Essas diferenças e autonomia, diante das relações com as referências artísticas internacionais, são distintas e variam de acordo com a pesquisa de cada artista brasileiro; como no caso de Wesley Duke Lee, que se relaciona com o surrealismo, Nelson Leirner, com o dadaísmo, e Antonio Dias e Rubens Gerchman, com o Nouveau Réalisme. Porém, ambos compartilham questões da Arte Pop no diálogo

\footnotetext{
${ }^{20}$ DUARTE, Paulo Sérgio. Anos 1960: Transformações da arte no Brasil. Rio de Janeiro: Campos Gerais, 1998, pág. 27.
} 
com as vanguardas internacionais, ora usando procedimentos e materiais industriais, ou explorando a linguagem dos meios de comunicação de massa [jornais, revistas em quadrinhos, embalagens ou imagens e anúncios de mercadorias, entre outros]. E Gross, com suas Nuvens, também compartilha esse diálogo com a Arte Pop em suas esculturas de "eucatex" pintadas com uma tinta de esmalte sintético, industrial. A artista explora em sua pesquisa plástico-poética os procedimentos industriais tanto no material do eucatex [um tipo de cópia de madeira feita industrialmente] na tinta esmalte como no recorte dos quadrinhos no desenho das nuvens. Esses desenhos-esculturas de Gross remetem ao processo de diagramação de desenhos de execução, e de leitura fácil, para produção e consumo de uma sociedade que visa à produção em série, e ao consumo imediato, de produtos e imagens. Contudo, em todo esse diálogo, que se estabelece a partir desses procedimentos e dispositivos poéticos da linguagem Pop, Gross experimenta plasticamente esse universo da arte pop através de uma singularidade poética, que absorve também as referências artísticas de uma arte paulista, da década de 1960.

A mudança política que se instala no país em 1964, com o golpe militar, e o Ato Institucional n. 5, em 1968, exigem novas posturas diante de uma sociedade atônita e oprimida pela súbita suspensão das liberdades democráticas. A ditadura militar no Brasil no final dos anos 1960 e na década de 1970 se transforma em um regime autoritário que viola os direitos humanos com prisões arbitrárias, torturas, mortes. Surge a censura aos meios de comunicação demarcando o impedimento da livre expressão de ideias. Paulo Sérgio Duarte comenta a censura nesse momento do país:

[...] nas artes plásticas, podia ir do fechamento de exposições ao amedrontamento dos artistas, à prisão, ao confinamento e internamento em hospitais psiquiátricos como ocorreu com dissidentes na União Soviética, e até ao assassinato. No Brasil, por exemplo, em 1968, foi fechada, pela polícia política, a II Bienal Nacional de Artes Plásticas, em Salvador, e as obras apreendidas nunca foram devolvidas aos artistas. O mesmo episódio se repetiu em outras ocasiões. Artistas foram submetidos a prisões e

\footnotetext{
${ }^{21}$ DUARTE, Paulo Sérgio. Anos 1960: Transformações da arte no Brasil. Rio de Janeiro: Campos
} Gerais, 1998, pág. 27. 
interrogatórios. Isso para não falarmos da censura à imprensa, ao teatro, à música; nas prisões, tortura e assassinatos de pessoas associadas à resistência à ditadura. ${ }^{22}$

Essas mudanças de contexto político na arte e na sociedade brasileira fomentam um repensar o Brasil com um novo olhar, uma urgência questionadora que contamina várias instâncias da sociedade. Em um momento de intensa movimentação político-social, é visível nas artes plásticas [e a partir dela] o surgimento de pesquisas, expressões, experimentações poéticas e propostas estéticas críticas, revelando uma vontade de renovação que gerou esse intenso experimentalismo, característico do ambiente artístico dessa época ${ }^{23}$. Paulo Reis contribui com sua análise sobre o projeto da vanguarda nacional no contexto dos anos 1960:

As experimentações da vanguarda nas artes plásticas brasileiras estavam inseridas também no diálogo com as movimentações artísticas internacionais e num quadro de resistência ao regime militar. O debate cultural da época construiu-se no trânsito entre a ação artística e a ação política. No encontro desses dois territórios, seja pela diferença de seus projetos, por aproximações dialéticas ou através de um programa unificador da vanguarda nacional, fundou-se uma das discussões de base daquela década.

[...] Nas discussões de artistas plásticos e crítica da época, foi pensado um projeto de vanguarda nacional que justapunha as artes visuais experimentais ao comprometimento político e social no contexto dos anos $60 .^{24}$

A vanguarda brasileira e seus embates artísticos e conceituais "formalizaram a possibilidade de uma arte experimental através do debate, com obras e textos, de um projeto de arte comprometida" ${ }^{25}$ com a política. Essa arte comprometida fica evidente em diversas exposições do período como Opinião 65, Propostas 66, Nova objetividade brasileira e Do corpo à terra. Entretanto, tanto no ambiente das artes plásticas no Rio de Janeiro como em São Paulo havia características próprias. De modo que a vanguarda paulista, desse período, tem suas especificidades poéticas representadas por artistas como Waldemar Cordeiro, Nelson Leirner, Wesley Duke

\footnotetext{
22 DUARTE, Paulo Sérgio. Anos 1960: Transformações da arte no Brasil. Rio de Janeiro: Campos Gerais, 1998, pág. 15.

${ }^{23}$ Daisy Peccinini e Paulo Sérgio Duarte compartilham a relevância do momento político opressivo da ditadura militar para o surgimento desse ambiente artístico brasileiro [tão variado].

${ }^{24}$ REIS, Paulo R. O. Arte de vanguarda no Brasil: os anos 60. Rio de Janeiro: Jorge Zahar Editor, 2006 , pág. 8.

${ }^{25}$ REIS, Paulo R. O. Arte de vanguarda no Brasil: os anos 60. Rio de Janeiro: Jorge Zahar Editor, 2006, pág. 29.
} 
Lee, Geraldo de Barros, entre outros. Sob essa perspectiva, poderíamos dizer que o diálogo com a Arte Pop na obra de Gross vem de um contexto brasileiro, especificamente paulista, que a artista vivenciava ainda como estudante, e que sem dúvida contribuiu para a particularidade do desenvolvimento de sua pesquisa e expressão individual, tanto naquele momento específico como para a construção de uma linguagem, uma poética própria.

Nuvens explora o vocabulário artístico da Arte Pop, porém é importante destacar a especificidade de sua experiência com esse vocabulário, ou seja, nesse período, a segunda metade dos anos 1960 [em São Paulo]: a FAAP [onde a artista fazia o curso de formação para professores de desenho] e seus professores, artistas e alunos de arte viviam uma época de coletividade, e, ao compartilhar esse ambiente artístico, seus ideais comuns se uniam em busca da liberdade de explorar e experimentar linguagens, materiais, conceitos e incentivar novas práticas artísticas, novos modos de pensar o sistema da arte e o mundo. Entretanto, a cidade de São Paulo [apesar de todo o seu progresso industrial] não oferecia uma prática artística profissional e a repressão da ditadura militar chegava às exposições de arte, "censuradas por obras consideradas ofensivas ao regime e aos bons costumes" 26 . E diante desse contexto de cidade um grupo de artistas se reúne em São Paulo com espírito de contestação, no intuito de provocar, romper com o provincianismo e estabelecer novas relações entre a sociedade, a prática e o sistema artístico. Eles pretendiam criar novas possibilidades de produção artística que movimentasse o diálogo. A formação do grupo que se autodenominou "Grupo Rex" se deu após a exposição Propostas 66, na FAAP, em São Paulo, organizada por Waldemar Cordeiro e o escritório de arquitetura dos artistas Sérgio Ferro e Flávio Império.

Nessa exposição havia artistas ligados ao concretismo paulista, à Nova Figuração e artistas que tinham participado da exposição Opinião 65, porém, devido à censura de algumas obras consideradas "subversivas", Nelson Leirner, Wesley Duke Lee e Geraldo de Barros retiraram suas obras como protesto à "infração ética" da censura. Então, a partir desse episódio, os três se juntam na defesa de objetivos

\footnotetext{
${ }^{26}$ DUARTE, Paulo Sérgio. Anos 1960: Transformações da arte no Brasil. Rio de Janeiro: Campos Gerais, 1998, pág. 37.
} 
comuns, de modo que em 1966 o Grupo Rex [com estes e outros três artistas jovens: Carlos Fajardo, Frederico Nasser e José Resende, ex-alunos de Wesley] inaugura seu espaço de exposições, a "Rex Gallery \& Sons", lançando nesse mesmo dia seu jornal, o Rex Time. Paulo Sérgio Duarte analisa esse momento da arte no Rio de Janeiro e em São Paulo e destaca como exemplo das transformações que estão ocorrendo a exposição no Rio de Janeiro, Opinião 65, e o Grupo Rex, em São Paulo. Em suas palavras:

Uma organização de artistas em São Paulo, de duração efêmera, mas cujos participantes marcaram e marcam até hoje, a produção de arte no Brasil: o Grupo Rex. $^{27}$

Os Rex, como se autointitulavam, demonstravam claramente sua insatisfação contra o estado das coisas no meio de arte. Uma série de "considerandos" explica os motivos do surgimento do grupo e de sua "declaração de guerra". A primeira crítica se dirige à falta de linha de conduta e de objetivos definidos das galerias que obriga os artistas a "se virarem por conta própria". O alvo seguinte é a carência de informação, de políticas editoriais e, em particular, da própria crítica de arte. ${ }^{28}$

As obras dos artistas do Grupo Rex, apesar das diferenças de cada integrante do grupo e da sua diversidade de propostas, discutem problemáticas do sistema da arte e da sociedade da época, compartilhando muitas insatisfações e inquietações, em experimentações e ações questionadoras, e até mesmo provocadoras. Na produção de Wesley Duke Lee é possível identificar duas principais vias, o desenho e a criação de ambientes. No desenho o artista escreve, no momento em que desenha, um texto como grafismo, deixando escapar o sentido literal das palavras. E, na realização de ambientes, junta meios e materiais novos [como acrílico, alumínio, sistemas eletrônicos], com meios tradicionais do desenho e pintura.

A ambientação experimental de Wesley e sua pesquisa se aproximam da poética de Gross, no sentido de uma proximidade estética e ideológica acerca dos caminhos e ações de um sistema e prática de arte, que parecem ter contaminado o percurso da artista em sua pesquisa plástico-poética. De fato é interessante destacar o diálogo estético entre os dois artistas, pois Gross, ao longo de seu percurso [como

\footnotetext{
${ }^{27}$ DUARTE, Paulo Sérgio. Anos 1960: Transformações da arte no Brasil. Rio de Janeiro: Campos Gerais, 1998, pág. 32.
} 
Lee], experimenta a linguagem da pintura e do desenho, que em sua pesquisa sai do papel e da moldura, e em seguida os transporta para ambientações. E nesse percurso experimental do desenho e da pintura que se expande a artista, anos mais tarde, introduz materiais, elementos eletrônicos em propostas de ambientes [instalações e/ou intervenções urbanas] coloridos por luzes de neon [como, em suas palavras, "pintadas com luz"].

Outro integrante do Grupo Rex interessante para destaque, como referência artística do ambiente paulista que Gross absorveu, é Geraldo de Barros. O artista, nesse período, trabalhava sobre imagens de outdoors, em uma pesquisa que misturava pintura e colagem. Desse modo, dialoga com a Arte Pop [ao se apropriar dessas imagens dos meios de comunicação] ao mesmo tempo em que explora, através das composições, uma linguagem que remete ao pensamento construtivo. Barros utiliza os mesmos procedimentos que os pintores paulistas naquele momento, que era a pintura sobre eucatex com esmalte para pintar as superfícies. Esse procedimento, aos poucos, fez com que muitos artistas abandonassem o pincel da pistola e se afastassem de um recurso artesanal, tanto no material como no instrumento. Isso se deve ao fato de que, nesse período, a maior parte das pesquisas artísticas buscava explorar os processos e procedimentos industriais. E, nesse sentido, tanto Gross como Barros [entre outros] compartilham nesse momento da mesma pesquisa, pois foi exatamente esse o procedimento utilizado pela artista na construção da sua obra Nuvens.

Gross, como aluna da FAAP, ao experimentar o compartilhar de ideias, as inquietações e experimentações inicia sua formação artística em meados dos anos 1960, em São Paulo. Essas questões estéticas, e outras, presentes nas pesquisas plásticas desses artistas paulistas, trazem problemáticas que surgem como referências que aparecem em sua pesquisa, sua poética. Na formação de um artista sempre há um ambiente que promove variadas experiências e instâncias de um saber artístico, que é vivenciado e incorporado por ele, contaminando sua poética. Contudo, o presente estudo não pretende estabelecer uma relação direta de influências e referências artísticas que tenham "formado" a poética de Carmela Gross. Pretendemos mapear

\footnotetext{
${ }^{28}$ DUARTE, Paulo Sérgio. Anos 1960: Transformações da arte no Brasil. Rio de Janeiro: Campos Gerais, 1998, pág. 37.
} 
diálogos que surgem com as experiências de artistas, e as problemáticas estéticas exploradas por alguns deles no período em que se dá a formação da artista, e que se desdobram em sua obra em um modo particular de experimentar, e criar, em sua poética.

Nesse período, no final dos anos 1960, o diálogo que havia das obras de Gross com as experiências de Hélio Oiticica revela que a artista fazia parte desse ambiente experimental artístico brasileiro, porém, Ana Maria Belluzzo ${ }^{29}$ comenta que Gross não conhecia os trabalhos de Hélio Oiticica, e que suas experiências eram estimulados por Flávio Motta. A palavra “desenho”, nesse momento, é lida por esses artistas e arquitetos em seu sentido mais amplo, uma nova percepção que inclui o desenho da cidade, o desenho arquitetônico, o desenho do objeto, o desenho gráfico, na utopia de um novo desenho de país, influenciada por um novo projeto, tanto de emancipação política como de autonomia artística. Para Belluzzo:

Confluíam para o novo entendimento político do desenho o pensamento do arquiteto Vilanova Artigas, que o considerava a linguagem da arte e da técnica, e as especulações do professor Flávio Motta, apreendendo-o em diversos momentos da vida urbana e rural, da vida cotidiana e artística. ${ }^{30}$

Havia um debate crítico brasileiro nessa época ${ }^{31}$, que para Ferreira Gullar problematizava conceitos de arte e política, no sentido de fundamentar-se como cultura nacional, que se expressava em diferentes concepções de vanguarda. Os modelos não funcionavam como uma cópia a ser reproduzida, pois a audácia criativa dos artistas brasileiros buscava uma visão crítica, e desejava se apropriar dos modelos internacionais, ressignificando-os, sempre em um contexto brasileiro. Alguns autores da época tentaram reduzir o debate sobre a pintura do final dos anos 1960, propondo uma separação entre a figuração, e sua leitura crítica de mundo engajada politicamente, e a abstração, associando-a somente a uma experimentação formal,

\footnotetext{
${ }^{29}$ BELluZZO, Ana Maria de Moraes. Carmela Gross. São Paulo: Cosac Naify, 2000.

${ }^{30}$ BELluZZO, Ana Maria de Moraes. Carmela Gross. São Paulo: Cosac Naify, 2000, pág. 22.

31 GULLAR, Ferreira. Experiência neoconcreta: momento-limite da arte. São Paulo: Cosac Naify, 2007.
} 
racional. Contudo, segundo Paulo Reis ${ }^{32}$, as pesquisas formais não estavam separadas das transformações sociais, eram experimentações de linguagens artísticas diferenciadas, mas que estabeleciam discursos poéticos de potencial transgressor, que ao ampliar sentidos, provocar reflexões, possibilitavam novas visões de mundo. As palavras de Paulo Reis sobre a vanguarda artística brasileira a partir da exposição Propostas 65:

"Propostas 65" colocou de lado a questão da figuração e da abstração em função de um conceito mais abrangente. O realismo propunha uma "forma de arte participante [...] [com] ponto de vista brasileiro dentro de um "novo humanismo"" (Mario Schenberg), "a pintura como fator de consciência social" (Sérgio Ferro) e a "realidade da cultura de massa como contraponto da arte" (Waldemar Cordeiro). A exposição se construiu sobre as discussões que já haviam sido abertas por "Opinião 65 " e formulou uma nova forma de olhar as manifestações artísticas nos anos 60, mais consistente que a propalada "volta à figuração". Tal forma de olhar agrupava trajetórias distintas e, ao não as opor, fornecia um conceito mais operacional de vanguarda aos artistas. Dois anos depois de "Opinião 65" e "Propostas 65", a exposição "Nova Objetividade brasileira" realizou uma súmula mais intricada das artes plásticas, ao construir e definir conceitualmente seu programa. ${ }^{33}$

Nessas exposições, artistas que desejavam criar novas possibilidades para repensar e vivenciar o sistema artístico, político e social, se juntam para promover ações experimentais, que questionam e provocam reflexões, sobre o sistema da arte e o mundo contemporâneo. Essas experiências demonstravam uma inquietação estética, social e política, criando um ambiente artístico que foi capaz de gerar uma multiplicidade de poéticas, como as propostas ambientais de Hélio Oiticica, os objetos interativos de Lygia Clark e o Grupo Rex, o qual, com suas ações artísticas, por meio de seu jornal e da galeria de arte, provocavam a ordem vigente do sistema de arte e da sociedade paulistana da época. As ações do Grupo Rex, através de suas propostas e textos no jornal, além dessas influências brasileiras, remetem à linguagem crítica da Arte Pop e das propostas de Marcel Duchamp e o dadaísmo. Sem dúvida, Marcel Duchamp é uma referência não só para o Grupo Rex, mas para toda uma produção que surge a partir dessas ideias, naquele momento. E isso se deu, nos anos

\footnotetext{
${ }^{32}$ REIS, Paulo R. O. Arte de vanguarda no Brasil: os anos 60. Rio de Janeiro: Jorge Zahar Editor, 2006.

${ }^{33}$ REIS, Paulo R. O. Arte de vanguarda no Brasil: os anos 60. Rio de Janeiro: Jorge Zahar Editor, 2006, pág. 44.
} 
1960, através de um processo de releitura da arte moderna, seus movimentos e artistas, no qual Duchamp e seus readymades têm um papel determinante. A influência de Duchamp e do dadaísmo se desdobra nesse período, como um ressurgimento da antiarte. Hélio Oiticica esclarece essa questão no sexto item de seu "Esquema Geral da Nova Objetividade" $" 34$ :

Por fim devemos abordar e delinear a razão do ressurgimento do problema da antiarte, que ao nosso ver assume hoje papel mais importante e sobretudo novo. ${ }^{35}$

[...] É essa a tecla fundamental do novo conceito de antiarte: não apenas martelar contra a arte do passado ou contra os conceitos antigos (como antes, ainda uma atitude baseada na transcendentalidade), mas criar novas condições experimentais, em que o artista assume o papel de "proposicionista", ou "empresário", ou mesmo "educador". O problema antigo de se "fazer uma nova arte" ou derrubar culturas já não se formula assim - a formulação certa seria a de se perguntar: quais as proposições, promoções e medidas a que se devem recorrer para criar uma condição ampla de participação popular nessas proposições abertas, no âmbito criador a que se elegeram esses artistas. [...] No Brasil (nisto também se assemelharia ao dadá), hoje, para se ter uma posição cultural atuante, que conte, tem-se que ser contra, visceralmente contra tudo, que seria, em suma, o conformismo cultural, político, ético, social. ${ }^{36}$

Variadas manifestações artísticas como a antiarte, a arte ambiental, a figuração, a abstração e ações artísticas experimentais formam parte de uma atitude, e de um discurso, em que todos estão igualmente comprometidos com os projetos culturais e políticos do país. Através dessas atitudes artísticas, e suas problemáticas plásticas, sociopolíticas e filosóficas, esses artistas exploram e determinam o pensamento dessa época como um todo. Paulo Reis comenta que "a trajetória de discussões e pesquisa de mais de dez anos na história da arte juntava-se à necessidade de 'opinião' sobre os fatos recentes [...] um rico episódio de embates com a realidade imediata através da tradição construtiva, da Arte Pop e do novo realismo"37. Nesse sentido é interessante apresentar a análise do crítico de arte Mario Schenberg sobre a amplitude de transformação na vanguarda brasileira dos anos 1960-1970:

\footnotetext{
${ }^{34}$ Hélio Oiticica escreve para o catálogo da mostra Nova Objetividade no MAM-RJ, em 1967, o texto "Esquema Geral da Nova Objetividade", em que analisa em seis itens, discriminando temas, as principais características da vanguarda brasileira desse período.

35 OITICICA, Hélio. Esquema Geral da Nova Objetividade. In: COHN, Sergio (Org.), Ensaios Fundamentais: Artes Plásticas. Rio de Janeiro: Beco do Azougue, 2010, pág. 121.

${ }^{36}$ OITICICA, Hélio. Esquema Geral da Nova Objetividade. In: COHN, Sergio (Org.), Ensaios Fundamentais: Artes Plásticas. Rio de Janeiro: Beco do Azougue, 2010, pág. 122.
} 
Cada transformação profunda na vida humana e social implica mudanças do sentimento espacial e das ideias filosóficas, matemáticas e artísticas sobre o espaço. Surgem assim novas concepções geométricas, novas relações entre o espaço e o seu conteúdo material e energético na física, novas formas de expressão na arte. ${ }^{38}$

A marca dessa amplitude de pensamento que surgiu nas vanguardas brasileiras pode ser percebida na atitude de Carmela Gross, quando cria novas possibilidades para repensar e vivenciar o sistema artístico, político e social, através de ações experimentais que questionam [e provocam reflexões] sobre o sistema da arte e o mundo contemporâneo. Essas experiências demonstram uma inquietação estética que aparece no início de seu percurso plástico, e que se mantém através de novas formas de expressão, novas relações com o espaço [do papel, das salas de exposições, das praças, prédios, e nos espaços da cidade], como motor poético até os dias de hoje. É notório perceber que o ambiente artístico experimental vivenciado nos anos 1960-1970, quando a artista ainda estudava na FAAP, direcionou uma liberdade, uma curiosidade de explorar novas formas, técnicas, materiais, que marcou seu modo de pesquisar e trabalhar o desenho, a pintura, os ambientes e suas inúmeras experiências estéticas ao longo de sua produção artística.

Outra referência para Gross a destacar, nesse ambiente artístico das vanguardas paulistas, foi Waldemar Cordeiro, que apresentou na exposição Opinião 65 dois Popcretos $^{39}$, nos quais utiliza relevos de madeira pintada, com espelhos e objetos do cotidiano. Nessas primeiras obras [seus Popcretos], Cordeiro expõe o conceito de uma arte concreta semântica como uma proposta alternativa à arte concreta, que para ele se tornara obsoleta. Segundo Paulo Reis, essas obras de Cordeiro representam uma transição entre os anos 1950 e 1960 em sua poética:

[...] Da mesma forma como ocorreu na trajetória de Oiticica, a poética de Cordeiro, informada pelo abstracionismo geométrico, foi se transformando no seio de sua própria

${ }^{37}$ REIS, Paulo R. O. Arte de vanguarda no Brasil: os anos 60. Rio de Janeiro: Jorge Zahar Editor, 2006, pág. 43.

${ }^{38}$ SCHENBERG, Mario. Arte e Tecnologia. In: COHN, Sergio (Org.), Ensaios Fundamentais: Artes Plásticas. Rio de Janeiro: Beco do Azougue, 2010, pág. 142.

39 Augusto de Campos, ao ver as obras de Waldemar Cordeiro na exposição Opinião 65, utilizou a palavra "popcretos" para designar esses trabalhos, devido à união das duas palavras, "pop" e "concreto". 
pesquisa. O contexto político e social anterior e posterior a 1964 e o diálogo com a Nova Figuração, em especial com o novo realismo e a Arte Pop, formaram alguns dos eixos que perpassaram a série de obras denominada Popcretos. Os Popcretos, ou arte semântica, como designava o próprio artista, afirmavam a urgência da reorientação do concretismo em direção ao contexto social daquele momento e à vontade de inserir-se numa ordem do tempo mais próxima da história. ${ }^{40}$

O diálogo de Cordeiro com a Nova Figuração em seus Popcretos aponta para um novo realismo que busca uma nova formulação da linguagem visual, de modo que se afasta da "nova figuração" no sentido de que pretende expandir os limites da representação direta dos objetos de produção industrial, através de outros recursos poéticos ao deslocar objetos do espaço físico para o espaço cultural, gerando assim signos expressivos. Cordeiro fala dessas obras:

Um novo realismo pressupõe uma nova formulação, que somente é possível dentro de uma nova linguagem visual. Coerentemente, o novo realismo - que nada tem a ver com a "nova figuração" - tanto nas manifestações norte-americanas - mais empíricas e diretas - assim como nas europeias - mais ideológicas -, supera os limites da representação direta das coisas da produção industrial em série. Retirar as coisas do espaço físico e colocá-las num espaço cultural criado é transformá-las em signos expressivos. Surge então uma nova ideia de coisicidade, que coincide com a semiótica. $^{41}$

Esses "signos expressivos" de um "novo realismo" que Cordeiro comenta explora uma linguagem visual que Gross experimenta em algumas de suas obras posteriores, através de instalações com letras luminosas. Nessas obras, como Us Cara Fugiu Correndo [Figura 6], Se Vende [Figura 7], Hotel [Figura 8], Eu Sou Dolores [Figura 9] e Aurora [Figura 10], a artista utiliza, em vez de objetos, palavras, frases deslocadas de seu contexto, como "signos expressivos", que constroem diálogos críticos, plástico-poéticos, com a cidade [e o sistema da arte]. De modo que essa experiência dos Popcretos de Waldemar Cordeiro, apesar de todo o distanciamento estético e conceitual entre suas propostas, indica um caminho plástico [semântico] que Gross, em sua singularidade poética, explora a partir dos anos 2000.

\footnotetext{
${ }^{40}$ REIS, Paulo R. O. Arte de Vanguarda no Brasil: os anos 60. Rio de Janeiro: Jorge Zahar Editor, 2006, pág. 36.

${ }^{41}$ Citações de Waldemar Cordeiro: LOPES, Fernanda. A experiência Rex: "Éramos o time do Rei". São Paulo: Alameda, 2009, pág. 76; Realismo - A musa da vingança e da tristeza, Revista Habitat, São Paulo, n. 83, 1965.
} 
Hélio Oiticica comenta a proposta de Cordeiro, com seu Popcreto, no "Esquema Geral da Nova Objetividade":

Em São Paulo, em outros termos nessa mesma época (1964-1965), surge Waldemar Cordeiro com o Popcreto, proposição na qual o lado estrutural (o objeto) funda-se ao semântico. Para ele, a desintegração do objeto físico é também a desintegração semântica, para a construção de um novo significado. Sua experiência não é a fusão de Pop com concretismo, como querem muitos, mas uma transformação decisiva das proposições puramente estruturais para outras de ordem semântico-estrutural, de certo modo também participantes. A forma que se dá essa transformação é também específica dele, Cordeiro, bem diferente do grupo carioca, com caráter universalista, qual seja, a da tomada de consciência de uma civilização industrial etc. Segundo ele, aspira à objetividade para manter-se longe de elucubrações intimistas e naturalismos inconsequentes. Cordeiro, com o Popcreto, prevê de certo modo o aparecimento do conceito de "apropriação" que formularia eu dois anos depois (1966), ao me propor a uma volta à "coisa", ao objeto diário apropriado como obra. ${ }^{42}$

Segundo Paulo Reis, "Na poética de Cordeiro não interessava, contrariamente a Hélio Oiticica, uma participação corporal e vivencial do espectador. O acionamento de significados da obra era dado nas malhas de significação (intelectivas) do trabalho"43. Os Popcretos de Cordeiro são colagens que, ao combinar imagens, ícones e palavras em uma escolha aleatória [em jornais e revistas], alude a experiências verbais e pictóricas do dadaísmo, porém com uma experimentação da forma. Quando Cordeiro utiliza as novas técnicas de gravura e reprodução, trabalha a intensa sobreposição e aglomeração em sua organização poético-espacial, uma pesquisa de sobreposição e aglomeração que dialogam com as pesquisas de Gross com as técnicas da gravura. Isso ocorre quando a artista utiliza, na obra Corpo de ideias [Figuras $11 \mathrm{e}$ 12], também a sobreposição [de figuras de uma enciclopédia visual] de xerox, em papel vegetal, construindo uma aglomeração de imagens reproduzidas em cópia heliográfica.

Nesse ambiente experimental Gross explora diversos meios, questões e operações plásticas pesquisando na gravura as técnicas de reprodução serigráfica, heliográfica, a cópia xerográfica, os processos fotográficos, projeções, entre outros.

\footnotetext{
${ }^{42}$ OITICICA, Hélio. Esquema Geral da Nova Objetividade. In: COHN, Sergio (Org.), Ensaios Fundamentais: Artes Plásticas. Rio de Janeiro: Beco do Azougue, 2010, pág. 115.

${ }^{43}$ REIS, Paulo R. O. Arte de vanguarda no Brasil: os anos 60. Rio de Janeiro: Jorge Zahar Editor, 2006, pág. 37.
} 
As técnicas tradicionais da gravura nos anos 1960-1970, ao ampliar suas técnicas por meio desses novos processos de reprodução, disponibilizam novos instrumentos de criação para os artistas, de modo que artistas como Gross e Waldemar Cordeiro [entre outros] incorporam e pesquisam em seus trabalhos a amplitude plástico-poética dessas novas técnicas. Ivo Mesquita ${ }^{44}$ considera que este período na obra de Gross se caracteriza como experimental, devido ao fato de que a artista realiza trabalhos sobre a construção da imagem, da representação, explorando meios como por exemplo a borracha, para criar diferentes carimbos com rápidos traços de desenhos na série Carimbos [Figuras 13 e 14]. Entretanto, é importante destacar que a pesquisa de Gross na série Carimbos se distancia das propostas de Waldemar Cordeiro quando trabalha com esses instrumentos [as novas técnicas de gravura e reprodução], um desenho totalmente desprendido de figuração. A artista aprofunda suas questões estéticas através de um diálogo do desenho tradicional [do lápis e tinta no papel] com essas novas técnicas de impressão. "Carimbos", que é uma série de desenhos realizada entre 1977 e 1978, composta das séries Carimbos-linhas [Figura 15], Carimbos-pinceladas [Figura 16], Carimbos-rabiscos [Figura 17] e Carimbos-manchas [Figura 18], foi apresentada no Gabinete de Artes Gráficas de São Paulo. As manchas, linhas e pinceladas livres sobre o papel, pela repetição mecânica dos "carimbos", se tornam uma metáfora do mundo contemporâneo e seu universo burocrático, onde o que é espontâneo, único, é transformado, formatado em um padrão a ser reproduzido no igual. Desse modo, o objeto-carimbo em madeira e borracha aprisiona o gesto espontâneo em seu carimbar automático no papel. E, assim, esse dispositivo plástico usado por Gross denuncia uma massificação que transmuta e aprisiona a liberdade do traço espontâneo, fluxo individual, em imagem civilizada, fixa, reproduzível e padronizada em série, como em um signo gráfico, de leitura fácil, para consumo imediato.

O desenho dos carimbos de Gross parece materializar o imaginário infantil que se expressa em traços, linhas curtas, riscos, rabiscos, grafismos, garatujas, garranchos, manchas, borrões, pinceladas de gestões efêmeros capturados por uma

\footnotetext{
${ }^{44}$ Entrevista com Ivo Mesquita. Catálogo da exposição Carmela Gross, um corpo de ideias. Curadoria e texto de Ivo Mesquita. São Paulo: Pinacoteca do Estado, 2010, pág. 25.
} 
matriz de borracha. A artista, ao elaborar esse ato do carimbar com a borracha no papel-cartão encadernado em espiral [que remete aos materiais escolares], propõe um jogo poético que se aproxima do ambiente escolar, dos carimbos de borracha, as brincadeiras e suas marcas no caderno, e no cotidiano escolar. Desse modo, ao mesmo tempo em que alude a esse ambiente, e ao imaginário infantil, a obra também propõe um questionamento conceitual, ao confundir o ato de carimbar com o ato de imprimir. Ou seja, em Carimbos Gross explora, também, o próprio limite do conceito de impressão da gravura, como categoria artística, ampliando seus materiais e suportes. Assim, problematiza a categoria artística que pode ser expandida a partir de novas experiências da impressão.

Carimbos, para Mesquita, trata da pintura, ao decodificar os elementos e procedimentos do desenho, tipos de linhas, pinceladas, que criam formas repetitivas com carimbos de borracha, em uma singular repetição que se apresenta em cada quadrado de papel A3, como fragmentos que se unem na totalidade do espaço da obra emoldurada. O autor destaca que Gross, em Carimbos, constrói uma pintura fria, mecânica, mas ainda manual, pois é uma pintura que, apesar da repetição e da disposição fria e dura dos elementos das linhas no papel, é uma pintura que tem gesto, ainda tem o movimento de uma mão no desenho, tornando-se então um gesto repetitivo e mecânico. Ivo Mesquita ressalta que essa repetição, essa multiplicação, que muito se revela nesse período experimental, acompanha todo o percurso plástico-poético de Gross.

Outra obra importante a destacar no percurso de Gross, que também explora a técnica da gravura, é Cartões familiares [Figura 19], uma série gráfica composta de 21 cartões realizada entre 1975 e 1977, anterior a Carimbos. Nessa obra, a artista experimenta no papel, com lápis preto e lápis de cor, variadas percepções simultâneas do cheio/vazio, construindo inversões de sentido do que é figura e do que é fundo, positivo/negativo, como croquis e exercícios de desenhos. Gross preenche o espaço com o grafite, tratando de questões próprias do desenho, utilizando uma máscara que possibilita a repetição-reprodução em série do motivo sobre o papel, como se fosse um diálogo poético com a técnica da serigrafia e do estêncil. São jogos no espaço do papel, no qual linhas retas formam cadeiras e camas repetidas. Entretanto, devido ao 
ritmo repetitivo da composição espacial, as formas distribuídas linearmente criam uma totalidade abstrata como um jogo espacial de imagens que amplia a visão das linhas, gerando outras interpretações, outras percepções. Sendo assim, ao desdobrar as linhas como fios, abstratos, anula-se o signo visual da cadeira, gravado no papel.

Esses jogos poéticos [da gravura], no espaço do papel, aproximam Gross da pesquisa plástica de artistas paulistas que estão atuando nesse ambiente inquieto da arte brasileira daquele momento. As experiências poéticas desse ambiente, como as problemáticas de outros artistas, são referências que parecem ter contaminado sua obra em um fluxo de absorção e pesquisa, em que questões plástico-poéticas latentes surgem e desaparecem por todo o seu percurso. Portanto, é importante destacar diálogos poéticos que atravessam seu caminho, como a obra de Wesley Duke Lee e seu Realismo Mágico, o qual estabelece relações com algumas de suas obras, desde o início como estudante da FAAP até hoje em dia. Hélio Oiticica comenta a importância da obra de Wesley Duke Lee [e do Grupo Rex] para a formulação da Nova Objetividade ${ }^{45}$ :

Um desenvolvimento independente, mas fundamental, é o do grupo do realismo mágico de Wesley Duke Lee, centrado na galeria Rex. Por incrível que pareça, apesar de sabermos da sua importância (que nesse processo descrito teria papel semelhante ao do grupo realista do Rio), pouco dele conhecemos. É um grupo fechado, extremamente sólido, mas do qual não podemos avaliar todas as consequências por desconhecermos a sua totalidade. Apenas vamos anotar aqui, além do Wesley Duke Lee (nome já conhecido fora do Brasil plenamente, e cuja experiência abarca várias ordens estruturais, desde as pictóricas às ambientais), os nomes de Nelson Leirner, Rezende, Fajardo e Geraldo de Barros, cujo desenvolvimento infelizmente desconhecemos, mas que sabemos interessantíssimo. Esta mostra servirá também para nos confirmar o que prevíamos: as premissas teóricas do realismo mágico como uma das constituintes nesse processo que me levou à formulação da Nova Objetividade, das principais correntes, grupos ou individualidades que colaboraram no seu processo constitutivo, aqui descrito neste item fundamental, ou seja, o da "passagem" e "chegada" às estruturas objetivas, considerando periféricas as mais gerais de ordem cultural, que interessam aqui como

\footnotetext{
45 A ideia de uma "Nova Objetividade" surge na exposição Propostas 66 na FAAP, em 1966, quando Hélio Oiticica começa a definir essa noção de uma "nova objetividade" no intuito de formular "um estado típico da arte brasileira" daquele momento. Comenta Oiticica: "Toda a minha evolução de 1959 para cá tem sido na busca do que vim a chamar recentemente de uma nova objetividade e creio ser esta a tendência específica da vanguarda brasileira atual [...]”. E em 1967 uma mostra foi realizada no MAM-RJ, organizada por um grupo de artistas e críticos de arte, como Mario Pedrosa, Mario Barata, Aracy Amaral, Mario Schenberg, Otavio Ianni, Villanova Artigas, Flávio Império, reunindo a diversidade das vanguardas nacionais. Hélio Oiticica escreve para o catálogo da mostra um texto, "Esquema Geral da Nova Objetividade", em que analisa em seis itens, discriminando temas, as principais características da vanguarda brasileira desse período.
} 
processo desta ordem e que, de um modo e de outro, influenciaram a eclosão do processo. Periféricas: Grupo Neoconcreto - Poesia Participante (Gullar), Grupo Opinião (teatro), Cinema Novo: Nova Objetividade - Lygia Clark, Realismo Carioca, Popcreto, Realismo Mágico, Parangolé. ${ }^{46}$

E é nesse ambiente artístico brasileiro que Carmela Gross, ainda como estudante da FAAP, é convidada por Wesley Duke Lee a participar de uma exposição na Rex Gallery \& Sons, em 1967, que se chamou Sex-Artistas, reunindo, como disseram na época, "os artistas de amanhã ${ }^{47}$ : Maria Diva Tadel, Iza Christina Ribeiro, Carmela Gross, Mario N. Ishikawa, Marcello Nitsche e Yoshiro Hashimoto. Todos esses seis jovens artistas estudavam no curso de formação para professores de desenho da Escola de Arte da FAAP, com a orientação de professores como Flávio Império, Flávio Motta e Sérgio Ferro.

O Grupo Rex, que questionava o tratamento dado ao ensino de arte no Brasil, considerava esse curso um dos poucos locais em que havia uma formação de orientação atualizada. Acreditavam que as propostas educativas da Escola de Arte da FAAP, influenciadas pelas inovações de artistas convidados como Wesley Duke Lee e de professores como Flávio Império, Flávio Motta e Sérgio Ferro ${ }^{48}$, criavam um ambiente criativo e irreverente de pesquisa experimental. Esses professores, que participaram da exposição Propostas 65 poucos anos antes, fomentavam um ambiente de vanguarda na universidade organizando seminários, debates, exposições, ações performáticas e eventos artísticos, que estimulavam a criatividade e a experimentação desses jovens. A ideia de Wesley Duke Lee para a exposição com esses jovens artistas da FAAP surge quando ele participa de um seminário na escola e conhece os trabalhos expostos de alunos. Lee se entusiasma com os trabalhos e

${ }^{46}$ OITICICA, Hélio. Esquema Geral da Nova Objetividade. In: COHN, Sergio (Org.), Ensaios Fundamentais: Artes Plásticas. Rio de Janeiro: Beco do Azougue, 2010, pág. 117.

${ }^{47}$ Fernanda Lopes comenta que Nelson Leirner considerava que os seis alunos da FAAP convidados a participar da exposição na galeria Rex Sex-Artistas eram a "verdadeira vanguarda brasileira, que é a vanguarda de jovens. São eles que têm a coragem da pesquisa". Cf. LOPES, Fernanda. A experiência Rex: "Éramos o time do Rei". São Paulo: Alameda, 2009, pág. 89.

${ }^{48}$ Sérgio Ferro, segundo Paulo Reis, fez algumas reflexões sobre o realismo e sua função crítica, nas quais afirma que a linguagem da pintura seria um meio para a conscientização social contra uma ideologia autoritária. Com suas palavras: "ao chamar de 'pintura nova' à pintura com responsabilidade de uma posição e fundada nos parâmetros da realidade, Ferro salientava seu posicionamento frente à realidade". Cf. REIS, Paulo R. O. Arte de vanguarda no Brasil: os anos 60. Rio de Janeiro: Jorge Zahar Editor, 2006, pág. 40. 
escolhe obras de cada um para montar a exposição. Marcello Nitsche, em entrevista a Fernanda Lopes, explica que o que havia de comum entre os artistas era a pesquisa de uma nova linguagem que dialogasse com o momento em que viviam. São estas as palavras do artista ao jornal O Estado de São Paulo antes da exposição:

Os cinco artistas afirmam outras identidades. A primeira é o processo de elaboração, vindo a idealização da obra antes da escolha do material. A outra identidade é o sentido crítico das obras, sendo algumas irônicas e outras francamente agressivas. Esse caráter denota, segundo os artistas, um reconhecimento do legado do dadaísmo. ${ }^{49}$

Apesar das semelhanças, há importantes diferenças entre eles. Nitsche, que se interessa por publicidade e os signos urbanos das placas de trânsito e cartazes, elabora um trabalho com essa linguagem do design gráfico. Carmela Gross, por sua vez, apresenta três esculturas, as quais descreve com suas palavras em entrevista concedida a Lopes:

\begin{abstract}
$\mathrm{Na}$ verdade eram moldes de escultura. Eu desenvolvi na aula de escultura da FAAP toda a modelagem de barro com estrutura de metal, e depois você fazia o molde de gesso para tirar uma cópia, o positivo, ou um gesso, ou outra coisa. Em vez de eu usar para eu fazer o positivo novamente, eu pintei esse molde e apresentei esse molde. [...] quando eu fiz o molde eu tava pensando nas relações espaciais e nunca no objeto em si, nunca no objeto em si, e isso permanece no meu trabalho até hoje. Meu componente mais forte é sempre uma questão espacial. ${ }^{50}$
\end{abstract}

Carmela Gross comenta a matéria de apresentação da exposição no jornal Rex Time, no qual havia fotografias dos seis artistas e desenhos feitos depois de um encontro com Carlos Fajardo [que escreveu a matéria]: "Fizemos os desenhos depois da conversa, no sentido de questionar mais ainda qual seria o papel dessa exposição" "51. E na mesma edição do jornal Rex Time os integrantes do Grupo Rex publicam a seguinte nota da redação: “[...] esperamos que essas respostas dos artistas,

\footnotetext{
${ }^{49}$ LOPES, Fernanda. A experiência Rex: “Éramos o time do Rei”. São Paulo: Alameda, 2009, págs. 93 e 92; Jovens farão primeira exposição. O Estado de São Paulo, 9 de março de 1967.

${ }^{50}$ LOPES, Fernanda. A experiência Rex: "Éramos o time do Rei”. São Paulo: Alameda, 2009, pág. 93. Entrevista com Carmela Gross concedida a Fernanda Lopes. São Paulo, 13 de dezembro de 2003.

${ }^{51}$ LOPES, Fernanda. A experiência Rex: "Éramos o time do Rei". São Paulo: Alameda, 2009, págs. 93-94. Entrevista com Carmela Gross concedida a Fernanda Lopes. São Paulo, 13 de dezembro de 2003.
} 
aparentemente paradoxais, mas no fundo coerentes com seus meios de comunicação, abram caminho poético entre público e artista" ${ }^{, 52}$.

A efervescência criativa, crítica, artística e cultural da FAAP, nesse momento, se deve à presença de certos professores que, ativos intelectuais de uma nova vanguarda experimental, buscavam novos caminhos, novos mundos para a arte [o ensino e o sistema], a arquitetura, a cultura, a política e a sociedade brasileira. $\mathrm{O}$ corpo docente daquele momento tinha como professores Sérgio Ferro e Flávio Império, que, além de darem aula no curso de formação de professores de desenho, integravam o Grupo Arquitetura Nova, junto com Rodrigo Lefrèvre, e que se configurava como um movimento de vanguarda na arquitetura e no urbanismo paulista dos anos 1960-1970. Esse grupo de professores trabalhou junto no Concurso Internacional de Escolas de Arquitetura da VI Bienal de São Paulo, representando a FAU da USP. Sérgio Ferro, nessa instituição, era assistente de Flávio Motta, um arquiteto e professor que tinha uma nova compreensão do desenho arquitetônico e urbano. No início de seu percurso plástico-poético Gross, ainda como aluna da FAAP, absorve esse ambiente de renovação das referências artísticas que, na década de 1960, na cidade de São Paulo, teve uma importante influência na construção de utopias, inovações e atitudes que tratavam de problemáticas artísticas e arquitetônicas.

As ações e provocações questionadoras da irreverência do Grupo Rex e as novas experiências e propostas na arquitetura do Grupo Arquitetura Nova inauguram um novo espaço de discussão através de inúmeros questionamentos críticos em relação ao estabelecido e ao convencional. Assim, surge uma produção experimental que sem dúvida contamina a formação de Carmela Gross. Essa herança experimental coletiva dos anos 1960 é ressignificada pela artista, trazendo para sua criação individual uma nova compreensão do desenho. Essa moderna compreensão, segundo Ana Maria Belluzzo, teria uma sólida tradição reflexiva, a qual se faz presente desde os escritos de Mário de Andrade até seus desdobramentos nas discussões das novas abordagens de Flávio Motta e do arquiteto Vilanova Artigas, em 1967.

\footnotetext{
${ }^{52}$ LOPES, Fernanda. A experiência Rex: “Éramos o time do Rei”. São Paulo: Alameda, 2009, pág. 94. Citação do Rex Time, São Paulo, n. 4, 10 de março de 1967.
} 
O desenho na obra de Gross pode ser percebido como um pensamento linear do espaço, ou seja, em suas obras parece haver linhas que atuam como contornos latentes se desdobrando em uma síntese que estrutura a obra, ativando [no espaço] um equilíbrio e uma harmonia do pensamento espacial do desenho. E essa linearidade se apresenta ao longo de toda a sua trajetória artística como uma estrutura de pensamento plástico que surge nas obras pictóricas, nos ambientes e nas cidades. $\mathrm{Ou}$ seja, sua poética explora tanto no papel como nos ambientes e intervenções nas cidades esse olhar, que às vezes cria volumes, em outras, desenhos de letras, ou apenas movimentos, direções, propondo ritmos, contornos, em sínteses de elementos plásticos que ativam múltiplas experiências. Sendo assim, em contínua pesquisa estética desde seus primeiros anos de trabalho, Gross experimenta diversas possibilidades da escultura e do desenho. E no seu percurso singular de pesquisa com o desenho produz interessantes trabalhos com a técnica da gravura, atingindo, nos anos 1980, uma maturidade com essa técnica visível em suas obras que evocam corpos celestes, e corpos de ideias [sutis e potentes] como Quasares [Figura 20], e Corpo de ideias. São obras de uma riqueza poética em que a técnica, devido a essa maturidade plástica, é incorporada à intensão poética da artista.

Corpo de ideias [Figura 21], que foi apresentada no Museu de Arte Moderna do Rio de Janeiro, é uma série de 11 gravuras em offset sobre papel, dispostas horizontalmente em uma grande extensão no chão, cobertas por um vidro que une e aprisiona as manchas abstratas em uma totalidade. O vivenciar da obra, através de um movimento do olhar, que busca capturar um signo em um reconhecimento representacional, logo é desviado, e absorvido, pela obra esparramada no chão. Em Corpo de ideias as imagens, que a artista reproduz milhares de vezes, criam um grande monocroma heliográfico. Nessa obra, Gross explora o processo da ampliação de cópias heliográficas sobrepostas, repetidamente, com imagens de ilustrações enciclopédicas, nas quais há figuras inventariadas de plantas, animais, objetos e instrumentos. A artista, nesse processo de manipular a imagem através da cópia heliográfica, escolhe uma figura simples no intuito de transformá-la. Ao escolher por exemplo uma imagem de planta, Gross elimina o volume e certos detalhes da figura, criando assim outra configuração. O resultado desse processo são figuras que 
fomentam, ainda, algo reconhecível, porém, agora, distantes de ser identificados como signos de leitura rápida e objetiva. No ato de ampliar, recortar, embaralhar e desfocar as configurações das quais partiu, a artista propõe, impossibilitando o reconhecimento do signo, um jogo formal com as estruturas das ilustrações escolhidas. Desconstrói assim a leitura de códigos gráficos da linguagem visual para possibilitar a experiência de uma apreensão abstrata, plástica, da totalidade do conjunto. Em Corpo de ideias ocorre uma apropriação poética de imagens esquecidas em uma enciclopédia, que são ressignificadas por outra narrativa, em outro território de signos. Essas imagens, agora fragmentadas, fora de seu contexto, reagrupadas, se sobrepondo, criam outros [múltiplos] "significados" visuais, ou seja, após uma série de transposições e acúmulo de imagens sobrepostas os registros gráficos [enciclopédicos], se transmutam em registros plásticos. Assim, Gross oferece ao espectador um "corpo" de ideias a serem ressignificadas, ampliadas, transmutadas e expandidas no espaço [da galeria], e na experiência de cada um.

Ainda nos anos 1980 Carmela Gross, mais uma vez, se apropria de imagens, sendo que aqui, na coleção Quasares de 1983, a artista desloca imagens do imaginário científico para materializar seus "quasares". Ou seja, a artista pesquisa as imagens de corpos celestes [recém-descobertos nessa época], classificados como "Quasares", e descritos como irreconhecíveis, quase estelares. Dizia-se que eram parecidos com a imagem de uma galáxia, mas que, por estarem muito distantes da Terra, não era possível medi-los. Desse modo, somente sua intensa energia [enviadas por ondas radioelétricas diferentes das estrelas] era captada. Gross, então, parece incluir em sua pesquisa plástica essas descobertas astronômicas, criando suas imagens [formas plásticas abstratas] a partir do que conhece dessas descobertas. Ana Maria Belluzzo acredita que foram as formas misteriosas e enigmáticas, criadas inicialmente pela artista, que a teriam inspirado na escolha do título Quasares [misteriosos corpos celestes] para a coleção. Nas palavras de Belluzzo: "Sucintas descrições, encontradas por Carmela em um guia de astronomia, fornecem nome para as experiências plásticas já concluídas. E as imagens recém-criadas passam a contar com a ressonância dos misteriosos corpos estelares" ${ }^{\text {53 }}$. Em Quasares, Gross desenha

\footnotetext{
${ }^{53}$ BELLUZZO, Ana Maria de Moraes. Carmela Gross. São Paulo: Cosac Naify, 2000, pág. 32.
} 
no papel manchas e sombreados pretos, ou cinza, criando um universo de formas que instigam uma investigação perceptiva, provocando indagações visuais diante de um rico vocabulário de elementos, quase homogêneos, que se destacam no centro de cada peça do conjunto de imagens. As sombras, em preto sobre o branco do papel, escapam a uma leitura de signos figurativos, ou jogos formais. Desse modo, aludem a um universo próprio, desfocado do real, do qual emergem formas ainda imperceptíveis, traduzidas por forças e intensidades de deslocamento, que se apresentam tanto individualmente, em cada peça, como se relacionam com o totalidade do conjunto.

A crítica de arte Aracy Amaral acredita que, apesar das pinturas e dos relevos pintados que se seguem a essas obras sobre o papel, no percurso de Gross o desenho enfatiza o caráter conceitual de sua produção, e continua a "desempenhar uma função de exercício, disciplina para a criação, ora operando junto, ora paralelamente a uma obra "maior"" 54 . A autora também analisa e ressalta a importância do papel diante das escolhas da artista:

[...] o carimbo assume vida sobre o papel, as imagens superpostas exploram as possibilidades do papel heliográfico, o desenho para a construção do céu ocupa vastos espaços sobre o papel, e as impressões "Quasares" eram igualmente sobre o mesmo suporte. $^{55}$

O desenho como linguagem surge na poética de Gross tanto em obras no papel como em suas experiências pictóricas e nos ambientes. Isto é, a poética de Carmela Gross, que se inicia em experimentações com o desenho e com a escultura, segue um percurso singular de pesquisa plástica com a linguagem do desenho, no qual constrói um vocabulário plástico próprio incorporando também questões da pintura. Ao longo do percurso artístico de Gross transparece todo um ambiente da arte brasileira nos anos 1960-1970, que a contaminaram e a estimularam a explorar questões e conceitos, que surgem em muitas de suas obras. E esse processo investigativo gera

\footnotetext{
${ }^{54}$ AMARAL, Aracy A. Textos do Trópico de Capricórnio: artigos e ensaios (1980-2005) - Vol. 3: Bienais e artistas contemporâneos no Brasil. São Paulo: Editora 34, 2006, pág. 237.

${ }_{55}$ AMARAL, Aracy A. Textos do Trópico de Capricórnio: artigos e ensaios (1980-2005) - Vol. 3 : Bienais e artistas contemporâneos no Brasil. São Paulo: Editora 34, 2006, pág. 236.
} 
fluxos poéticos, que se desdobram em suas pinturas-objetos nos anos 1980, período em que a artista dialoga com o contexto artístico do momento.

\section{2}

\section{O pictórico poético}

Na trajetória artística de Gross, a pintura é explorada através de novos formatos e materiais. Sua herança experimental gera uma inquietude que se abre a novas perspectivas de criação e na conquista da liberdade, do confrontar-se com o estabelecido. A artista apresenta uma riqueza de novas propostas pictóricas. Gross inicia seu percurso artístico no Brasil em um momento em que técnicas tradicionais como pintura, desenho, gravura e escultura davam lugar a experiências artísticas inovadoras. A artista, nesse contexto, é contagiada por novas relações de sentido [plástico-poético], que são experimentadas através de diversas manifestações artísticas, como a arte ambiental, conceitual, mesclando meios, materiais e discursos plástico-poéticos. Hélio Oiticica, em seu "Esquema Geral da Nova Objetividade", descreve o momento histórico brasileiro [no final da década de 1960, início dos anos 1970], no qual Gross também absorve as mesmas problemáticas plásticas. Nas palavras de Oiticica:

O fenômeno da demolição do quadro, ou da simples negação do quadro de cavalete, e o consequente processo, qual seja, o da criação sucessiva de relevos, antiquadros, até estruturas espaciais ou ambientais, e a formulação de objetos, ou melhor, a chegada ao objeto de 1954 em diante, se verifica de várias maneiras, numa linha contínua, até a eclosão atual. ${ }^{56}$

[...] Há então, cronologicamente, uma sucessiva e variada formulação do problema, que nasce como uma necessidade fundamental desses artistas, obedecendo ao seguinte processo: da démarche de Lygia Clark em diante, há como que o estabelecimento de handicaps sucessivos, e o processo que em Clark se deu de modo lento, abordando as estruturas primárias da "obra" (como espaço, tempo etc.) para a sua resolução, aparece na obra de outros artistas cada vez mais rápido e eclosivo. ${ }^{57}$

\footnotetext{
${ }^{56}$ OITICICA, Hélio. Esquema Geral da Nova Objetividade. In: COHN, Sergio (Org.), Ensaios Fundamentais: Artes Plásticas. Rio de Janeiro: Beco do Azougue, 2010, pág. 112.

${ }^{57}$ OITICICA, Hélio. Esquema Geral da Nova Objetividade. In: COHN, Sergio (Org.), Ensaios Fundamentais: Artes Plásticas. Rio de Janeiro: Beco do Azougue, 2010, pág. 113.
} 
[...] Daí em diante surge, no Brasil, um verdadeiro processo de "passagens" para o objeto e para proposições dialético-pictóricas, processo este que notamos e delineamos vagamente, pois que não cabe, aqui, uma análise mais profunda. ${ }^{58}$

A exposição "Nova Objetividade", realizada no MAM-RJ em 1967, revela a partir dos trabalhos expostos desde a afirmação de posições políticas, como a superação do quadro de cavalete, à participação corporal, tátil e visual do espectador. Carmela Gross encontra nesse ambiente de liberdade e ousadia criativa novas relações de sentido, que a impulsionam a explorar problemáticas do desenho e da pintura ampliando experiências e conceitos. Assim, o pictórico poético em Gross nasce de um contexto artístico da arte brasileira que nos anos 1960, segundo Oiticica, buscava a superação dos suportes tradicionais, em proveito de estruturas ambientais e objetos. Gross, ao trabalhar técnicas e procedimentos [herdeiros] dessa linguagem experimental, realiza nos anos 1980 obras pictóricas que exploram problemáticas da pintura que surgiram nas vanguardas dos anos 1960. Nessas pinturas realizadas pela artista, transparece uma liberdade [poética], adquirida na possibilidade do experimentar a forma no suporte da tela, ou da parede, ou mesmo do chão. E desse modo voltar a problematizar questões da pintura, como a superação do quadro do cavalete, em seu envolvimento com as questões da matéria [e da cor monocromática], no diálogo com o espaço expositivo.

Entre 1985 e 1987 Gross desenvolve Pintura-Desenho [Figura 22], que é o nome dado a uma série na qual a artista fabrica diferentes tamanhos e formatos de chassis, criando superfícies com formas únicas e expressivas em materialidade e espessura. Nos anos 1980 houve um retorno à pintura, tanto no Brasil como no exterior, em que prevalecia um pintar no deleite da expressão pictórica, e a maioria dos trabalhos explorava o prazer dos gestos pictóricos e das cores. Gross em suas pinturas explorou essas novas atitudes plásticas pesquisando, experimentando, uma poética pictórica através de gestos largos, trabalhados em chassis com formatos inusitados, em uma redução cromática. Embora se perceba nas pinceladas gestuais de Gross os "estilos" de pintar dos anos 1980, a artista se mantém em sua pesquisa plástica. A poética pictórica de Gross explora, a partir dos atributos cromáticos dos

${ }^{58}$ OITICICA, Hélio. Esquema Geral da Nova Objetividade. In: COHN, Sergio (Org.), Ensaios 
materiais, um vocabulário de formas, gestos e ritmos, como uma gramática plástica própria. Suas diversas formas e materiais ativam questões pictóricas em um discurso plástico que pode ser percebido ao longo de uma série de trabalhos. Aracy Amaral comenta que a artista fala desse período como uma transição ["possível encontro"] entre a pintura e o desenho: "Um desenho que delimita, projeta, arma e se enrijece na geometria rigorosa de encaixes, e uma pintura que busca o expressivo e a fluidez da matéria cromática, em descrições do símbolo e do clichê" ${ }^{\text {59 }}$.

Cada tela da série Pintura-Desenho [Figura 23] se estende, de sua operação formal [em cores e manchas], aos diferentes formatos dos suportes, em uma dinâmica relacional entre as diversas telas na parede. Assim, cada tela se relaciona entre si e com o espaço expositivo, criando um diálogo plástico-poético entre o pictórico e o espaço, como um conjunto unificado e integrado, em uma totalidade que envolve toda a sala. Assim, sua dimensão física no espaço real da parede expande os limites entre as telas e instaura um diálogo com o espaço expositivo. Essas relações que se estabelecem com o espaço nas pinturas de Gross remetem às experiências neoconcretas inauguradas por Lygia Clark ${ }^{60}$. Ferreira Gullar [outro integrante do grupo neoconcreto] escreve sobre a obra de Lygia nesse momento: "Os quadros de Lygia não têm moldura de qualquer espécie, não estão separados do espaço; estão abertos para o espaço que neles penetra e neles se dá incessante e recente: tempo"61.

Essa abertura para o espaço também é percebida em outra obra de Gross, a Linha-objeto [Figura 24], de 1988, que faz parte da série Pintura-Objeto, na qual amplia a experiência plástica da pintura expandindo a relação suporte-parede para se corporificar diretamente no espaço. Em Linha-objeto o movimento do olhar é envolvido em um desenho dinâmico, circular, composto de pequenos traços, como

Fundamentais: Artes Plásticas. Rio de Janeiro: Beco do Azougue, 2010, pág. 113.

59 Citação de Carmela Gross no ensaio de Aracy Amaral "Carmela Gross: um olhar em perspectiva", de 1993, extraída do catálogo Pintura/Desenho, São Paulo, MAC-USP, 1987. In: AMARAL, Aracy A., Textos do Trópico de Capricórnio: artigos e ensaios (1980-2005) - Vol. 3: Bienais e artistas contemporâneos no Brasil. São Paulo: Editora 34, 2006, pág. 237.

${ }^{60} \mathrm{O}$ processo experimental de Clark mostra inicialmente molduras largas no mesmo nível da tela, sendo que em algumas delas a composição plástica sai da tela para a moldura, incluindo-a desse modo ao espaço virtual da obra. Depois, em sua pesquisa a artista suprime definitivamente a moldura, que ao ser incorporada faz com que o espaço virtual da tela se expanda até o limite do espaço real.

${ }^{61}$ GULLAR, Ferreira. Experiência neoconcreta: momento-limite da arte. São Paulo: Cosac Naify, 2007, pág. 80 . 
formações constelares, unificados no espaço da parede. Esse desenho interior da Linha-objeto se apresenta também em outra obra dessa série, Expansivo [Figura 25], do mesmo ano. Nesse trabalho, que ocupa uma grande extensão da parede, o desenho interior surge como uma estratégia de ocupação do espaço, que acolhe o movimento do expandir de um ponto a outro da parede. Os fragmentos do corpo da obra criam um traçado de formas que se espelham e se equilibram, em um ritmo veloz, direcionado por uma força interna, de um fluir expandido na parede. "Estou chamando essa última fase de meu trabalho de 'pintura-objeto' para poder manter as duas definições. É o tempo inteiro um jogo entre os limites [...] Estou mais interessada na virtualidade da pintura que na concretude do objeto", diz Gross ${ }^{62}$.

$\mathrm{Na}$ obra Expansivo, Gross, ao fragmentar o corpo da obra na parede, deixa o espectador criar sua Gestalt, sua obra. Nessas operações poéticas a artista cria uma linha invisível, que induz o olhar a um contorno formal da obra no espaço da parede. Esse dispositivo plástico de uma linha, que delimita o espaço formal da obra, já havia sido explorado por Lygia Clark. Clark percebe a existência de uma "linha" nos limites que organizam o espaço entre as portas, o chão e a parede, e leva essa percepção para sua pintura. Ricardo Basbaum ${ }^{63}$ descreve esse conceito da linha orgânica de Clark como uma linha que não é escavada, nem marcada, por ninguém, mas surge do contato entre duas superfícies como planos, coisas, objetos, corpos, e até mesmo conceitos. Ferreira Gullar, em sua "teoria do não objeto" [elaborada nesse período], comenta essa pesquisa de Clark:

Foi da tela em branco que Lygia Clark partiu para criar sua "Superfície modulada" placa de madeira cortada em duas por uma fissura (que ela chamava de "Linha orgânica") início de um desmembramento do quadro de que surgiriam os "Casulos" e depois os "Bichos". O não objeto nasce, portanto, do abandono do espaço virtual (ou fictício) e da ação pictórica (metafórica) para o artista agir diretamente sobre a tela (o quadro) como objeto material, como coisa. Esta ação do artista se transfere ao espectador que passa a manipular a nova obra - o não objeto - em lugar de apenas contemplá-lo. ${ }^{64}$

\footnotetext{
${ }^{62}$ LAGNADO, Lisette. Carmela Gross pesquisa os limites da pintura. Folha de São Paulo, São Paulo, pág. E4, 14 de agosto de 1990.

${ }^{63}$ BASBAUM, Ricardo. Within the Organic Line and After. [s.n.t.]

${ }^{64}$ GULLAR, Ferreira. Experiência neoconcreta: momento-limite da arte. São Paulo: Cosac Naify, 2007, pág. 46.
} 
Apesar de nesse sentido a pintura de Gross se aproximar das experiências de Clark, sua pesquisa experimental segue por outras intenções conceituais, diferentes propostas, e experiências perceptivas que exploram outros caminhos. Entretanto, nesses caminhos de Gross permanece a herança experimental que problematiza e explora a participação do espectador. Todo esse ambiente, de que a artista participou em sua formação [nos anos 1960-1970 em São Paulo], estimulou questões e conceitos que foram sendo explorados em muitas de suas obras posteriores. Sendo assim, para analisarmos os trabalhos de Gross dos anos 1990, como as obras Praia [Figura 26], Trem [Figura 27] ou Peixes [Figura 28], é importante retomar essa questão da participação do espectador, conceito que Oiticica enfatiza, e expõe, em seu "Esquema Geral da Nova Objetividade":

O problema da participação do espectador é mais complexo, já que essa participação, que de início se opõe à pura contemplação transcendental, se manifesta de várias maneiras. Há, porém, duas maneiras bem definidas de participação: uma é a que envolve "manipulação" ou participação "sensório-corporal", a outra, que envolve uma participação "semântica". Esses dois modos de participação buscam como que uma participação fundamental, total, não fracionada, envolvendo os dois processos, significativa. Isto é, não se reduzem ao puro mecanismo de participar, mas concentram-se em significados novos, diferenciando-se da pura contemplação transcendental.

[...] o que se procura é um modo objetivo de participação ativa do espectador nesse processo: o indivíduo a quem chega a obra é solicitado à contemplação dos significados propostos na mesma - esta é, pois, uma obra aberta. Este processo ${ }^{65}$ como se surgiu no Brasil, está intimamente ligado ao da quebra do quadro e à chegada ao objeto ou ao relevo e antiquadro (quadro narrativo). Manifesta-se de 1001 modos desde o seu aparecimento no movimento neoconcreto através de Lygia Clark e tornou-se como que a diretriz principal do mesmo, principalmente no campo da poesia, palavra e palavra-objeto.

[...] verifica-se em todas as novas manifestações de nossa vanguarda desde as obras individuais até as coletivas (happenings, por exemplo). Tanto as experiências individualizadas como as de caráter coletivo tendem a proposições cada vez mais abertas no sentido dessa participação, inclusive as que tendem a dar ao indivíduo a oportunidade de "criar" a sua obra ${ }^{66}$.

\footnotetext{
${ }^{65}$ Segundo Oiticica, esse processo que procura de modo objetivo a participação do observador está presente "Desde as proposições 'lúdicas' às do 'ato', desde as proposições semânticas da 'palavra pura' às da 'palavra-objeto', ou às de obras 'narrativas' e as de protesto político ou social [...]". Cf. OITICICA, Hélio. Esquema Geral da Nova Objetividade. In: COHN, Sergio (Org.), Ensaios Fundamentais: Artes Plásticas. Rio de Janeiro: Beco do Azougue, 2010, pág. 118.

${ }^{66}$ OITICICA, Hélio. Esquema Geral da Nova Objetividade. In: COHN, Sergio (Org.), Ensaios Fundamentais: Artes Plásticas. Rio de Janeiro: Beco do Azougue, 2010, pág. 118.
} 
Essa oportunidade do espectador "criar" a sua obra aparece em trabalhos nos quais Gross explora a linguagem e a matéria pictórica nos anos 1990, como Praia, em que pedaços dispostos no chão se assemelham a uma pedra que foi partida em quatro, em Trem, que são 21 partes de alumínio fundido alocadas lado a lado na parede da sala expositiva, e Peixes, em que várias unidades irregulares e pontiagudas, de tamanhos semelhantes, criam elementos quase escultóricos, diferentes, que saem da parede em direção ao espectador. Gross com essas obras instiga o espectador a vivenciar uma experiência perceptiva a partir de fragmentos que ativam todo o espaço. E no expandir da exterioridade das tensões plásticas que se organizam e agenciam as forças do olhar que compõem a figura totalizada. Desse modo, a artista problematiza a fisicalidade do espaço, e a presença do espectador no processo de construção da obra. Essas e outras obras que exploram a participação do espectador com o espaço expositivo propõem ao espectador criar relações de significados novos e individuais, diante das experiências com suas obras. Esses diálogos com questões da percepção do espaço e da interatividade das obras não só faz parte de uma herança artística de Gross em sua formação nos tempos da "Nova Objetividade", mas se apresenta como uma constante de sua poética em todo o seu percurso plástico poético até os dias de hoje.

As ideias da fenomenologia de Maurice Merleau-Ponty eram muito discutidas e exploradas plasticamente, tanto nas pesquisas das vanguardas internacionais como no Brasil dos anos 1960. A abordagem fenomenológica de Merleau-Ponty, que explora as questões do espaço-tempo da experiência estética, e a participação do observador na construção da obra, foi a base de todo o pensamento neoconcreto [e o que se desdobrou dele]. Entretanto, essa problemática apresentada pelo filósofo é absorvida por Gross a partir de uma leitura própria, que remete aos artistas do Grupo Rex, entre outros, que tratam das mesmas questões dos cariocas, porém com outro vocabulário estético, próximo ao contexto do ambiente artístico da cidade de São Paulo. Ronaldo Brito comenta:

[...] a ideia de participação, com o sentido de romper o predomínio do puramente óptico na fruição do trabalho de arte, teve uma importância básica no neoconcretismo. Sua origem teórica eram os escritos fenomenológicos de Merleau-Ponty, que serviram 
de apoio ao grupo neoconcreto do Rio de Janeiro em sua ruptura com o grupo concreto de São Paulo. ${ }^{67}$

Lorenzo Mammi ${ }^{68}$ contribui com sua análise da arte brasileira desse período, e as relações estéticas e socioculturais entre as cidades de São Paulo e Rio de Janeiro.

Nas suas palavras:

Por ocasião da polêmica de 1957, Cordeiro defendeu, como vimos, uma objetividade absoluta da forma, que vedava qualquer carga simbólica. Uma linha era uma linha: não podia significar outra coisa além de si mesma. Mas naquele momento a produção industrial deixava de ser essencialmente produção de objetos para se tornar, sobretudo, produção das imagens dos objetos, a serem transmitidas pelos meios de comunicação de massa. Se o artista concreto quisesse manter sua capacidade de intervenção sobre os mecanismos sociais de produção, a arte concreta deveria se tornar, de crítica da forma, crítica das imagens e dos signos. Em outras palavras, a teoria da forma concreta deveria necessariamente desembocar, como de fato aconteceu em São Paulo, numa semiótica.

No Rio, a relação com a indústria não foi tão determinante. Ferreira Gullar afirmava que uma linha, antes de ser uma linha, é uma experiência do sujeito que a traça ou que a vê, e que essa experiência originária (espaço, corpo, matéria, ausência e presença, vazio e cheio) é o verdadeiro objeto da arte. É uma posição que resvala naturalmente não numa semiótica, mas numa fenomenologia, numa crítica dos signos, e sim numa crítica da experiência. Mas numa sociedade coberta de signos, a crítica da experiência só pode acontecer como marginalidade, alternativa à experiência existente: e por aí se encaminhou o neoconcretismo. Por outro lado, a crítica dos signos, como começou a se delinear em São Paulo, só era possível pela ironia, que extrai as imagens do fluxo cotidiano e as manipula invertendo ou abolindo seu sentido. A transição para a Pop Art de algumas personalidades de ponta do grupo (Geraldo de Barros, Nogueira Lima, Fiaminghi e, de um jeito peculiar, Waldemar Cordeiro) é, nesse sentido, coerente. Nos dois casos, porém, o projeto coletivo da arte concreta, como relação orgânica entre produção artística e processo de modernização, já acabara. ${ }^{69}$

Sendo assim, o diálogo que se estabelece entre a obra de Gross e as problemáticas comuns ao neoconcretismo remete à sua relação com a vanguarda paulista, a qual ressignifica sua herança concreta em uma releitura das ideias de Oswald de Andrade, Flávio de Carvalho, as questões duchampianas, entre outras experimentações estéticas das vanguardas internacionais. Embora haja uma

\footnotetext{
${ }^{67}$ BRITO, Ronaldo. Com o espaço construído. In: LIMA, Sueli de (Org.), Experiência crítica - textos selecionados: Ronaldo Brito. São Paulo: Cosac Naify, 2005, pág. 45.

68 MAMMİ, Lorenzo. Concreta '56: A Raiz da Forma. In: COHN, Sergio (Org.), Ensaios Fundamentais: Artes Plásticas. Rio de Janeiro: Beco do Azougue, 2010, págs. 85-97.

69 MAMMİ, Lorenzo. Concreta '56: A Raiz da Forma. In: COHN, Sergio (Org.), Ensaios Fundamentais: Artes Plásticas. Rio de Janeiro: Beco do Azougue, 2010, págs. 95-96.
} 
proximidade de Gross com a estética e com as questões do neoconcretismo, na singularidade de sua pesquisa plástica é visível que a artista não pretende introduzir o espectador no centro de sua obra, mas ativar jogos poéticos que instiguem no espectador tanto o penetrar no interior da obra como o se distanciar dela. Isto é, seus jogos poéticos, ao alternar posições e relações perceptivas, se desdobram em múltiplas possibilidades de obras que, dependendo do ponto de vista e/ou do envolvimento do espectador com o espaço expositivo, ativam no ambiente uma variedade de experiências plásticas.

Na série Pintura-Objeto a artista explora dispositivos pictóricos que se lançam diretamente na parede [ou no chão], ativando no espaço expositivo um campo de possibilidades expressivas. Nos trabalhos de 1990, Gross experimenta com a madeira descascada e pintada a óleo construir corpos escultóricos, monocromáticos, com volume e espessura irregulares. Essas obras da série, nomeadas de Parte vermelha [Figura 29], Parte amarela [Figura 30] e Parte prata [Figura 31], se constituem de corpos dispostos verticalmente, presos à parede, que ativam uma relação sensorial do universo da cor, da matéria e da forma abstrata com o espaço expositivo. Gross explora nessas obras uma relação perceptiva dos elementos plásticos, ao mesmo tempo em que é ativado no espectador um penetrar na extensão ambiental e arquitetônica do espaço expositivo. A artista, nessa obra, propõe a partir de um objeto [a "pintura-objeto"] que não termina em si mesmo, mas se inicia nele, tratar de uma operação de entendimento formal, que ativa no espaço a experiência estética.

Ao longo de seu percurso artístico, a artista absorve e dialoga com um ambiente experimental, que pesquisa as possibilidades expressivas da pintura, de modo que sua poética pictórica atua em uma pluralidade de meios e suportes em ambientes nos museus, galerias, em prédios abandonados, arquitetura de escola, ônibus e cidades. Há momentos em que se dedica a desenvolvimentos formais da cor e forma, em outros amplia percepções [e conceitos] ao explorar o suporte do chão, e da parede, em obras como Expansivo ou Facas [Figura 32]. E nos diálogos site specific com o ambiente e com a cidade a artista demarca uma poética em que o pictórico se anuncia através de diferentes materiais, meios e procedimentos utilizados. A questão da "cor" na multiplicidade de suas estratégias plástico-poéticas surge quase como uma 
constante, nas quais cria ambientes banhados de cor no deslocamento cotidiano de um ônibus escolar, em uma experiência de explorar a teoria da cor em CARNE [Figura 33]; ou também no dialogar das questões formais da cor e espaço, na intervenção do prédio da escola na França [Figura 34]; ou ainda em suas instalações dos anos 2000 que "pintam" os espaços com a força poética das luzes coloridas de neon. Assim, questões formais, espaciais e conceituais da pintura em Gross engendram uma Obra singular que, ao ativar espaços em um deslumbramento plástico [pictórico], gera conjuntos, séries, coleções, instalações e intervenções urbanas. E, na força de sua poética visual, amplia conceitos, provoca reflexões e novas percepções.

\section{3 \\ Os ambientes}

A singularidade do tratamento do espaço na poética de Gross gera, também, experiências estéticas em ambientes, em obras como As 28 Operações [Figura 35], de 1999. Nessa instalação a artista propõe uma experiência sensorial a partir de 28 painéis de tecido [pendurados em hastes de ferro], presos perpendicularmente às paredes, na qual, ao tocar cada painel, percebe-se a possibilidade de movimento que cada um deles tem de girar 180 graus. Desse modo Gross instiga o espectador a experimentar a obra, a criar seu ambiente, suas sensações, sentimentos, estabelecendo novas relações de sentidos entre as cores, as transparências dos tecidos, que ao se misturarem revelam sombras, criam novas formas. O movimento ao caminhar pela obra, e a liberdade de deslocamento que ela promove, convida o espectador a desvendar e experimentar sua poética. São sete estandartes de tamanhos diferentes e distribuídos em grupos de sete, alocados nas laterais da sala retangular, possibilitando muitas combinações dependendo do posicionamento dos elementos diante do conjunto. Devido à sua mobilidade, as hastes de ferro de onde pendem os tecidos permitem ao espectador entrar em contato com uma diversidade de texturas, cores e formas, misturando e superpondo os tecidos durante os movimentos, ativando no 
ambiente uma atmosfera de mistério, de descobertas a cada novo passo. Ao provocar uma movimentação nos painéis de tecidos, no dialogar do corpo de quem passa pela sala, seduz tátil e visualmente o espectador, promovendo uma experiência que instiga a imaginação, a memória, a fantasia.

Ao caminhar [experimentar] com/na obra, em sua variedade de combinações possíveis, dentro da brancura extremada do ambiente, Gross propõe a materialização de um mundo imaginário que se revela no fruir com a obra. E essa poética do espaço está presente tanto em 28 Operações como em Feche a porta [Figura 36], uma instalação de 1997 que é composta de barras de ferro sustentadas pela parede e levemente elevadas do chão. Nessa obra, Gross recorta o espaço expositivo com várias barras de ferro encostadas à parede, propondo relações espaciais definidas. A artista traça linhas no espaço arquitetônico [expositivo] como se esses ambientes tivessem sido desenhados no papel e saíssem do chão em estruturas de ferro articuláveis. São estruturas que, ao serem manipuladas, aludem a paredes, porteiras, portas se abrindo e fechando. Contudo, a partir de outros pontos de vista, podem remeter a grandes cadeiras presas na parede. Portanto, sua matéria, forma e movimento articular das estruturas são como dispositivos plásticos, poéticos, que geram inúmeras possibilidades de criar, desenhar novos espaços, imaginar novos mundos através do corpo/pensamento. Ana Maria Belluzzo analisa essa obra de Carmela Gross, apresentada no Centro Cultural São Paulo, em 1997:

O projeto possui um princípio de base, um axioma que dá conta de possíveis variáveis de todo sistema de relações. Trinta e seis módulos quase iguais são derivados de estrutura cúbica, aberta e incompleta. Através desses artefatos mecânicos repetidos, a artista procede operações mentais precisas, gerando relações espaciais definidas. Joga portanto com a profundidade do pensamento matemático e a exterioridade da experiência, que ocorre no espaço ocupado pelo corpo. Provoca desconcerto. ${ }^{70}$

Assim, Feche a porta pode gerar algum estranhamento devido ao seu indagar poético, que instiga diferentes experiências espaciais em cada espectador aberto ao fruir com a obra. Entretanto, o interessante de se destacar nesse ambiente de Gross é o devir poético no espaço ativado pelas linhas das peças de ferro [revestidas de pó

\footnotetext{
${ }^{70}$ BELLUZZO, Ana Maria de Moraes. Especulações. Catálogo da exposição (folder) Carmela Gross. São Paulo: Centro Cultural São Paulo, 1997.
} 
grafite] e suas estruturas vazadas, possibilitando múltiplas percepções e situações poéticas, que flutuam como ideias em suspensão. Os ambientes de Carmela Gross ativam esse devir poético através de diferentes propostas e experiências como em 28 Operações, em que a artista explora questões pictóricas com os panos colorindo o espaço expositivo, e em Feche a porta, em que cria e estrutura situações no espaço.

Nesse contexto ambiental a artista cria uma obra para a $20^{\text {a }}$ Bienal Internacional de São Paulo [Sem título] [Figura 37]. Gross, nessa Bienal, constrói uma instalação que ocupa as quatro paredes do espaço expositivo com dois painéis murais [em uma escala quase monumental] e duas paredes com intervenções de materiais diferentes a cada lado. Na primeira parede, manchas, sombras, projetam sobre a sala gestos curvos e amplos no espaço de um enorme painel pintado com cores suaves, que variam do rosa ao marrom, cinza e branco, em formas de movimentos amplos, simples e livres de significado. Compõe um espelhamento difuso com o segundo painel [na parede em frente], feito de uma suave superfície de papel de fibra artesanal, com suas formas pintadas de tinta prateada. Os dois painéis dialogam, espelhando-se tanto na forma similar como na diferença da cor/não cor entre si. Esses dois enormes painéis provocam no ambiente um acolhimento que pode conduzir o espectador a uma leitura da obra a partir de fragmentos de memória ancestral, remetendo à imaginação os desenhos das cavernas, ou mesmo ao mito de Platão e sua caverna dominada pela ilusão. Contudo, na caverna de Gross os reflexos, sombras do real, são mitos inventados a cada experiência estética, pela liberdade do espectador em construir suas relações de sentido entre as partes, de conceber seu mito, que ativa a experiência do espaço, que contamina e amplia reflexões, sentidos e sentimentos.

$\mathrm{Na}$ terceira parede, outra escala é explorada por desenhos com traços finos e suaves, riscos que se projetam a diferentes caminhos. Construída com hastes de metal pintado de preto, denuncia tensões da ambiguidade existente entre o traçado da mão e o material fundido. Ao sugerir livremente a forma de um X [de grandes dimensões], essa parede instiga o espectador a construir relações com o objeto da parede à frente. É um aglomerado de sucessivas folhas de mica rasgadas, com aspecto de lança, preso à parede por um eixo de ferro, que indaga ao ponto central do suposto $\mathrm{X}$ um sentido. Esse ponto, ao espelhar essa comunicação entre as paredes, promove inúmeras 
possibilidades de diálogos; seria uma direção, uma referência espacial exata para esse um único ponto na parede à frente? Ou essa referência apenas alerta caminhos [linhas] desconexos, em direções próprias, opostas? $\mathrm{Na}$ experiência estética da caverna de Gross surge um X que marca ou anula alguma certeza? Seria um ponto central a ser atingido? Mas, como no pensamento do arqueiro Zen do budismo, o que menos importa é a resposta, ou a flecha no alvo. A artista convida o espectador ao estranhamento, ao mistério da caverna e suas sombras. E ali continua seu jogo de indagar, refletir, provocar e ativar, através da experiência estética, o universo da liberdade poética, individual, do imaginar, criar, expandir percepções, conceitos e novas visões de mundo.

Esses ambientes de Gross evocam jogos sutis de percepção e de sentido, instigando o olhar do espectador segundo um nexo próprio, ativado a partir do fruir com a obra. Nesse sentido, um espectador nesse ambiente que gera um estranhamento, um indagar poético, pode reviver, através de novas percepções, certas relações do cotidiano ressignificadas a partir de novas relações de sentido poético. Desse modo, nessas propostas ambientais, Gross estaria indagando e provocando uma experiência do espaço que convidaria a imaginação do espectador a visitar universos complexos. Isto é, através de jogos sutis de percepção e de sentido, a artista estaria propondo uma multiplicidade de ambientes, territórios a serem explorados, ressignificados no deslocar poético de signos e contextos culturais, como na obra Facas $^{71}$. Facas [Figura 38] é um conjunto de 1.300 peças em cerâmica, composto de cores, formatos e tamanhos variados, dispostos no chão, ocupando uma larga extensão de espaço expositivo da galeria. Carmela Gross, mesmo diante da repetição das linhas na composição do desenho espacial, constrói no espaço expositivo um universo serial, que do uno ao múltiplo prevalece a identidade singular do conjunto. Em um jogo sutil que remete ao cotidiano, desloca contextos e percepções em novas relações de sentido. Desse modo, surgem aproximações entre as lascas, os cilindros e as formas pontiagudas das peças de cerâmica de Gross com os artefatos de cerâmica

\footnotetext{
${ }^{71}$ Facas foi um trabalho que resultou do convite de uma bolsa de pesquisa, realizada no European Ceramics Work Centre, na Holanda, onde Carmela Gross trabalhou de fevereiro a maio de 1994. A obra apresentada pela primeira vez na Holanda, nessa instituição, foi exposta no CCBB do Rio de Janeiro nesse mesmo ano, e no MAM de São Paulo no ano seguinte.
} 
de achados arqueológicos. Ou seja, as lascas e formas pontiagudas aludem a algum tipo de instrumento, ou utensílio cotidiano, só que de outro tempo, outra cultura. Assim, configuram-se plasticamente como deslocamentos simbólicos, que agenciam novas relações de sentido, ativando no espaço da sala um universo poético próprio, construído pelo vocabulário [plástico] da artista. Gross, em Facas, instiga no espectador mais uma experiência estética que gera reflexões e novas construções de sentido [plástico e poético] diante de suas formas individualizadas, metafóricas, múltiplas, na estrutura serial e equilibrada do espaço. A artista nessa obra se apropria de elementos estéticos que geram conexões entre signos na presença da singularidade, do toque individual, que registra uma identidade a cada peça, no corpo coletivo. Ao formar o conjunto da obra, a imagem do coletivo, carregado de força individual, surge contaminando todo o ambiente da sala, demarcando um território simbólico próprio a partir de suas interações poéticas.

Os ambientes de Gross promovem a vivência de diferentes universos plásticos e simbólicos através de experiências com o espaço, que geram novas percepções, sensações, reflexões, criando novas relações de sentido poético a cada proposta. $\mathrm{Na}$ instalação Hotel Balsa [Figuras 39 e 40] a artista propõe uma experiência no espaço que convida o espectador ao centro da obra, ou seja, através de estratégias poéticas de um processo de deslocamento explora a questão do observador na construção da obra. O convite surge a partir de uma engenhoca de trilhos e madeira, que transita pelo espaço como uma balsa a ser habitada, ou hospedada, por um breve período de deslocamento "dentro" da obra. Ao longo de uma das paredes estão distribuídos, irregularmente, fragmentos geométricos com iluminação interna, que se apresentam como variados pedaços de luz branca, que têm volume e se materializam em tamanhos e formatos diferentes, cobrindo toda a extensão da parede da sala. Na outra parede há pedaços de espelhos que têm exatamente o mesmo formato dos pedaços de luz à sua frente. Esses espelhos atuam no espaço como brechas, fendas de possibilidades diversas, por onde pode se mirar [espiar] os fragmentos de luz do outro lado. E através de uma mecânica de deslocamento lento [da engenhoca na forma de balsa, percorrendo todo o espaço da sala], as duas paredes e seus dispositivos luz-espelho se relacionam. De modo que, nesse hotel-balsa, o observador possa, em um 
movimento contínuo, criar a sua obra. Ou seja, integrar poeticamente o espaço da obra como um todo, diante do processo de fragmentação que a obra explora, no qual Gross não só escreve as palavras em pedaços, mas constrói com elas duas esculturas que se inscrevem despedaçadas na totalidade do espaço expositivo. A obra, como um todo, abriga um navegar no espaço da galeria que propõe esse integrar de "fragmentos" em um vagar que alude a outro tempo, um tempo da narrativa individual construída no deslocamento poético de cada um, e que ativa a experiência estética no percurso de um lado a outro da sala. Desse modo o espectador, durante o lento deslocamento que a balsa promove, pode explorar várias possibilidades de leituras, perceber novos ângulos de visão, múltiplas combinações sensoriais e metafóricas.

Hotel Balsa, segundo o crítico de arte Paulo Sérgio Duarte, estabelece dois polos em que a palavra "hotel" é corpo e imagem. A primeira parede, que ele chama de Hotel-Luz, seria a mestra, enquanto a outra, Hotel-Espelho, a escrava, que passivamente apenas parecia refletir a cena. Uma atuaria luminosa, e se exibiria, e a outra seria sua testemunha. Nas palavras de Duarte:

Seremos sombra e reflexo na rápida hospedagem no H O T E L-L U Z e no H O T E L-E S P E L H O. Atuaremos inteiros como personagens da rigorosa e simples geometria, construída, também, para termos certeza de que o mundo ou as palavras feitos em pedaços está assim para que possamos reconquistá-lo na sua integridade durante a percepção em movimento e, recuperando e resolvendo as partes no todo, de novo as palavras e o mundo voltem a fazer sentido. ${ }^{72}$

No final dos anos 1990, Gross começa a explorar um material que será experimentado de diversas maneiras pela artista nos anos 2000. São as luzes de neon que passam a ser usadas em muitos de seus ambientes e em obras posteriores, diálogos poéticos com o sistema da arte e as cidades. Essas luzes de neon são utilizadas pela primeira vez na obra o Comedor de Luz [Figura 41], de 1999-2000, na qual a artista instiga o espectador a uma experiência pictórica poética do espaço expositivo. A instalação é composta de barras de ferro, luz fluorescente e fios, com diferentes partes articuladas entre si. São luzes fluorescentes em estruturas metálicas,

\footnotetext{
72 DUARTE, Paulo Sérgio. Três passagens em torno de uma instalação. Texto para a exposição individual Hotel. São Paulo: Gabinete de Arte Raquel Arnaud, 2003.
} 
que lhes dão articulação possível sobre o chão, ou lhes servem de apoio para elevar-se acima do piso. O dobrar e desdobrar dessas partes desenha no chão diferentes formatos ao serem encostados em um canto, ou apoiados na parede. A luz difusa, ao ser instalada em um ambiente escuro, envolve todo o espaço, impregnando-o de cor amarela, em que a textura e a cor convidam a um deleite quase tátil dos sentidos. Assim, o ambiente tomado por essa intensa luz amarelada funciona como se fosse um fundo para um desenho que a forma das lâmpadas e das fiações compõe em primeiro plano. Desse modo, um conteúdo gráfico, em contornos de linhas que encerram e separam o traçado de luz e máquina, surge como uma garatuja. A obra, gerada na experiência da cor e de sentidos ampliados, estabelece uma atmosfera que revela aos poucos um esboço de formas, ou objetos, ambíguos, em uma potência de associação, significação, que nunca se realiza completamente.

Moacir dos Anjos, em um artigo sobre essa obra, fala do desejo utópico da artista de reconstruir, idealmente, o mundo exterior da perspectiva de quem mora aquém da paisagem. Acredita que esse desejo está presente tanto em suas nuvens de madeira pintada [Nuvens, de 1967] como quando a artista desenha com lápis de cor no papel seu Projeto para a construção de um céu [1980-1981]. Para ele, na poética de Gross, “a cidade não fica 'lá fora', mas dentro de cada um que se deixa impregnar por (ou que 'come') tudo aquilo que dá substância e feitio a ela"73.

A artista constrói um singular vocabulário plástico ao longo de seu percurso, que sugere um pensamento do desenho na força poética da composição de suas formas, cores e materiais. Ao acompanhar o percurso plástico poético de Gross, o presente estudo destacou algumas passagens desse percurso no intuito de contribuir para a compreensão de um vocabulário próprio que surge de uma trajetória artística marcada pela curiosidade de ações poéticas em busca de novas experiências no universo plástico. A inquietação artística de Gross se revela através de processos experimentais, nos quais sua pesquisa de formas, cores e materiais é uma constante. Sendo assim, em seus múltiplos caminhos artísticos com o desenho e a pintura, a artista envolve problemáticas estéticas, urbanas e sociais que se desdobram em obras

\footnotetext{
73 ANJOS, Moacir dos. Projeto sem fim. Catálogo da exposição Carmela Gross. Recife: Museu de Arte Moderna Aloísio Magalhães, 2003.
} 
críticas [conceituais] nos ambientes e nas cidades. Gross, com seu olhar inquieto e investigativo, ao estabelecer diálogos com o espaço do papel, da arquitetura, com o sistema artístico e com as cidades, gera uma poética que expande percepções, conceitos, limites subjetivos, propondo uma interlocução com a arte, o homem e o mundo. 


\section{Capítulo II. Carmela Gross e o diálogo com a cidade}

As obras de Carmela Gross se desnudam através de uma poesia plástica que instiga um experimentar e o vivenciar de um território artístico singular. Suas imagens são capazes de articular discursos [potentes e singelos] sobre a arte e a sociedade contemporânea, que se abrem para o outro e para o mundo, expandindo e contaminando tanto os ambientes dos museus [e galerias de arte] como os espaços das cidades. O diálogo que se estabelece entre as obras de Gross e as cidades convida os passantes a uma experiência dos sentidos que explora uma poética particular a cada contexto de cidade. Em São Paulo, a individuação dos sentidos pode ser uma tarefa árdua no cotidiano desordenado, barulhento e conturbado, de uma megaescala de cidade que extrapola os limites de convivência entre os habitantes. A artista, entretanto, promove uma relação com esse universo contextual e escolhe se expressar plasticamente [a partir dos anos 2000] de acordo com o instrumental [tecnológico] da cidade contemporânea, e assim provoca desdobramentos conceituais, poéticos, também a partir dos materiais escolhidos. Gross, em seu diálogo com a cidade, elabora projetos para locais específicos [site specific] através de um trabalho rigoroso com materiais industrializados, que geram uma multiplicidade de narrativas diante da especificidade que cada local promove. Assim, a cada obra instalada, tanto nos espaços urbanos como em espaços internos, institucionais, prevalece sua singular poética, que gera uma sutil e potente imagem artística. Nas palavras de Moacir dos Anjos:

Carmela Gross traz, para o espaço institucional e supostamente asséptico da arte, ecos da transversalidade e do sincretismo definidores do espaço da cidade. Faz repousar, na calma regular de salas de exposição, objetos que, usualmente, acentuam e afirmam o tempo corrido e variado do campo urbano. Em vez do pulso comunicativo e 
massificado que exibem em inúmeros cartazes e placas, as lâmpadas assim deitadas carregam, em seu descanso forçado, a promessa da individuação de seus sentidos. ${ }^{74}$

Esses ecos da transversalidade e do sincretismo dos elementos que evocam a cidade de que Moacir dos Anjos nos fala surgem na poética de Carmela Gross. Suas obras provocam, desestabilizam, interrompem o fluxo normativo que, muitas vezes, ativa nos ambientes uma experiência estética que expande limites conceituais. Nesse sentido, a artista ativa novos territórios poéticos que atuam como territórios móveis, em constante definição de um lugar poético, proporcionando trocas de subjetividades entre obra e espectador. Nessa multiplicidade simbólica Gross demarca ambientes de mistérios poéticos a serem desvendados, como jogos a serem experimentados.

Ao propor esses jogos, a artista cria a possibilidade de ativar por uma manifestação artística novos territórios subjetivos, móveis, que se aproximam da noção de território migrada da filosofia de Deleuze e Guattari ${ }^{75}$, a qual amplia o conceito de territorialização da etologia ${ }^{76}$. Dependendo do contexto e dos diálogos estabelecidos a partir da obra, são engendrados provisoriamente novos lugares de existência, nos quais a experiência estética ativa percepções, reflexões e a criação de novas relações de sentidos, novos territórios subjetivos, ou seja, novos territórios poéticos. O conceito de território é uma boa opção para se definir a noção de "lugar" no contexto de uma cultura contemporânea marcada por transitoriedade, deslocamento, fluxo e aceleração. Nesse contexto as obras de Gross, muitas vezes, propõem ao indivíduo passante das cidades [que se deixam contaminar por sua poética] experimentar provisoriamente novos lugares de existência como territórios móveis, em constante transformação. Sua poética instiga diálogos com a percepção, com o corpo, convidando o espectador/passante a novas conexões sensoriais, político-filosóficas, e reflexivas. Desse modo, Carmela Gross abre seu trabalho ao mundo,

\footnotetext{
${ }^{74}$ ANJOS, Moacir dos. Projeto sem fim. Catálogo da exposição Carmela Gross. Recife: Museu de Arte Moderna Aloísio Magalhães, 2003.

${ }^{75}$ DELEUZE, Gilles; GUATTARI, Félix. Mil platôs. Capitalismo e esquizofrenia. São Paulo: Editora 34, 2008 (4. reimpr.). 1. ed. bras., 1997. $4 \mathrm{v}$.

${ }^{76}$ Para Deleuze e Guattari, território é um conceito fundamental de sua filosofia, que trata de diferentes noções do termo sem uma visão hierarquizada, pois para eles é apenas uma mudança de natureza. $\mathrm{Na}$ filosofia deles, o conceito filosófico de território traz de certa forma tanto uma visão da psicologia, da sociologia, como da geografia. Desse modo, engloba todas essas noções, ao mesmo tempo que amplia o conceito para além delas. Portanto, o termo "território" pode ser interpretado como espaços físicos estético-culturais e simbólicos.
} 
através de uma potente poesia plástica, que dialoga com a cartografia urbana das metrópoles contemporâneas, propondo uma nova geografia de afetos.

Em suas interferências urbanas a artista "escreve" nas cidades suas metáforas ${ }^{77}$, onde muitas vezes suas obras surgem como motivadoras de uma experiência estética no universo urbano. Na relação entre obra e cidade, a poética de Gross convida o espectador/passante a perceber as relações plásticas e conceituais com o local específico. E desse modo, ao vivenciar a obra na cidade, o espectador pode construir todo um outro sentido nas relações obra e cidade cotidiana, em seu fluxo e fluidez, que passa a ter outras possibilidades de leituras. Nesse sentido, as obras de Gross nas cidades podem dialogar com a noção de site oriented, analisada por Mywon $\mathrm{Kwon}^{78}$, que tem sua origem nos trabalhos crítico-institucionais que surgiram nos anos 1970.

Ao analisar as transformações, ao longo de trinta anos, do conceito de site-specificity e sua adequação dos trabalhos aos espaços físicos, Mywon Kwon considera que o trabalho feito sempre se constrói a partir de uma dimensão discursiva específica. Isto é, trata-se de uma abordagem de site-specificity, entretanto, o ser "específico" em relação ao local a ser realizada a obra difere do primeiro momento de site specific do minimalismo ${ }^{79}$. A diferença estaria no decodificar das convenções institucionais, pois site-specificity busca explorar as operações ocultas de significados que moldam o significado da arte, diante de seu valor econômico e cultural ${ }^{80}$. Nas primeiras formas de abordagem crítico-institucional, eram exploradas as condições físicas do espaço de exposição como ponto de partida para expor as operações ocultas

\footnotetext{
${ }_{77}^{7}$ Seus signos, símbolos plásticos e linguísticos.

${ }^{78}$ KWON, Mywon. Um lugar após o outro: anotações sobre site-specificity. Arte \& Ensaios, Rio de Janeiro (EBA-UFRJ), n. 17, págs. 167-188, 2008.

${ }_{79}$ Segundo Mywon Kwon, o trabalho site-specific, em sua primeira formação, focava no estabelecimento de uma relação indivisível entre o trabalho e sua localização, e demandava a presença física do espectador para contemplar o trabalho. Se no minimalismo o espectador recuperou um corpo físico, as práticas de teor crítico institucional insistiram no padrão social de classe, raça, gênero do espectador. E enquanto o minimalismo desafiava o hermetismo idealista do objeto de arte autônomo, ao atribuir seu significado ao espaço de sua apresentação, a posterior abordagem crítico-institucional complicou ainda mais esse deslocamento ao enfatizar o hermetismo idealista do espaço de apresentação em si. Os espaços das galerias/museus (institucionais) não eram mais considerados por sua arquitetura, nem eram percebidos em termos de dimensões básicas e proporções, mas como uma convenção normativa de exposição a serviço de uma função ideológica. O site inclui uma gama de vários espaços e economias diferentes que se inter-relacionam, entre eles o ateliê, a galeria, o museu, a crítica de arte. A história da arte, o mercado da arte, que juntos constituem um sistema de práticas que não está separado, mas aberto às pressões sociais, econômicas e políticas.
} 
das convenções institucionais. Atualmente as manifestações de site-specificity tenderiam a tratar as preocupações estéticas [e históricas da arte] como questões secundárias, em que a busca é de um maior engajamento com o mundo externo e a vida cotidiana ${ }^{81}$. Mywon Kwon afirma que nos últimos trinta anos a definição operante de site foi transformada de localidade física - enraizada, fixa, real - em vetor discursivo - desenraizado, fluido, virtual. E conclui apontando os três paradigmas de site-specificity: o fenomenológico, o social/institucional e $\mathrm{o}$ discursivo. E que, apesar de apresentados de maneira cronológica, não são estágios em uma trajetória linear de desenvolvimento histórico. Para a autora, são definições que competem entre si, sobrepondo-se uma à outra e operando simultaneamente em várias práticas culturais, ou mesmo em um projeto específico de um artista. E, nesse sentido, é o que encontramos no diálogo da obra de Gross com a cidade e com as instituições de arte, ou seja, no qual essas definições fenomenológicas, social/institucional e discursiva, atuam como forças poéticas simultâneas na relação da obra com o lugar [específico].

No universo contemporâneo da arte, a diversidade está presente tanto nos conceitos como nos materiais, na sua expressão, e nos múltiplos pontos de vista, conexões e entendimentos por parte do espectador. A poética contemporânea revela toda uma extensa variedade de territórios subjetivos ativados por obras que evocam questões conceituais artísticas, políticas, sociais, culturais, entre outras. Desse modo, o campo da arte surge como recurso para se repensar conceitos, e descobrir novos procedimentos para se problematizar e interpretar a sociedade. Assim, através de outros modos de pensar, agir, se ativam outros diálogos e discursos construídos na diversidade da reflexão coletiva, e na subjetividade de cada indivíduo. Nesse sentido, as propostas artísticas contemporâneas dialogam com o cotidiano, com as questões socioeconômicas, políticas e culturais, e, mudando os parâmetros, os paradigmas, transforma também a própria noção de arte.

\footnotetext{
${ }^{80} \mathrm{O}$ objetivo atualmente, segundo Kwon, é tornar aparente sua imbricada relação com processos socioeconômicos e políticos mais amplos da atualidade.

${ }^{81}$ Essa crítica da cultura, para Mywon Know, busca incluir espaços não especializados, instituições não especializadas em arte - borrando a divisão entre arte e não arte. De modo que, hoje, esse engajamento expandido com a cultura favoreceria locais "públicos", fora dos confins tradicionais da arte em termos físicos e intelectuais.
} 
Existem atualmente trabalhos que são orientados para o site, os quais ocupam hotéis, ruas, projetos de moradia, prisões, escolas, hospitais, igrejas, zoológicos, supermercados, e também se infiltram nos espaços da mídia como o rádio, o jornal, a TV e a internet. Esses trabalhados site specific de hoje [denominados como site oriented por Mywon Kwon] procuram integrar a arte mais diretamente no âmbito do social, seja para reendereçar problemas sociais urgentes (crise ecológica, de moradia, racismo, exclusão) ou relativizar a arte como apenas uma das muitas formas de trabalho cultural. Essa expansão ${ }^{82}$ da arte na cultura, que obviamente diversifica o site, tem como característica principal um site determinado discursivamente, e através do qual é delineado como um campo de conhecimento, fomentando um debate cultural.

As obras de Gross se deixam ler como ligadas a um horizonte de problemas que, em última instância, pode se aproximar do site oriented que Kwon descreve. Ao instigar novos agenciamentos éticos e estéticos, ativam nas cidades um discurso plástico poético que integra a arte ao âmbito social. Entretanto, é importante destacar a singularidade e a complexidade de sua poética, na qual esse desdobramento no site não é determinante como campo de conhecimento, somente aberto a discussões e reflexões. Há obras de Gross nas cidades como Fonte/Foz [Figura 42] e Cascata [Figura 43], em que a artista estabelece uma relação fenomenológica com o desenho geográfico das cidades de Laguna e Porto Alegre, respectivamente. São intervenções plásticas que, ao serem elaboradas e instaladas para promover espaços de convivência, expandem seus limites conceituais como obra de arte, que se converte pelo uso urbano, cotidiano, em praça e escada. Isto é, obras de arte que, no uso cotidiano de suas funções urbanas, silenciosamente se tornam parte da cidade.

$\mathrm{Na}$ amplitude de sua poética, as obras de Gross ora promovem experiências nas cidades, ora "territórios urbanos" da experiência da cidade são ativados no interior de espaços institucionais como museus e galerias de arte. E, através de metáforas

\footnotetext{
${ }^{82}$ Além dessa expansão espacial, segundo Mywon Kown, a arte site oriented também é informada por uma gama ampla de disciplinas [antropologia, sociologia, crítica literária, história cultural e natural, arquitetura e urbanismo, informática, teoria política] e dialogam em sintonia com discursos populares como moda, música propaganda, cinema e TV. O site agora é estruturado (inter)textualmente mais do que espacialmente, e seu modelo não é mais um mapa, mas um itinerário, uma sequência fragmentária de eventos e ações ao longo de espaços.
} 
plásticas, repletas de signos do espaço urbano, engendram territórios poéticos da cidade, como nas instalações Us Cara Fugiu Correndo, Eu Sou Dolores e Aurora. Esses discursos plásticos do campo da cidade trazem ao espectador a possibilidade de interpretá-la, praticá-la dentro do museu/galeria de arte. As reflexões, questionamentos, e sentidos ampliados da experiência da cidade, ativam no espectador todo um novo sistema de encontros e agenciamentos do experimentar a cidade. Possibilitam, assim, a partir da vivência dessa escrita dentro dos espaços institucionais da arte, a criação de uma nova cartografia poética que flui da relação arte e cidade.

Em obras como Us Cara Fugiu Correndo [Figura 44], signos deslocados da cidade invadem sensorialmente o Museu de Arte Moderna de São Paulo. A criação dessas novas relações, ativadas na experiência estética, cria um novo conjunto de ações, representações, e apropriações subjetivas móveis. Nessa obra, uma intervenção no espaço da parede de entrada no museu, Gross inscreve plasticamente [como um grafite escrito em luzes de neon], o gesto e o pulsar da vida das ruas. Através do material frio da luz de neon vermelha, a frase "Us Cara Fugiu Correndo" é escrita em letras finas e ligeiramente entortadas, como se escritas à mão. E ao cortar as letras pela metade, na parte de baixo, parecendo não ter tido o tempo de completá-las, a artista evoca a poética de uma ação urbana, fugaz. Uma ação que remete à dos grafiteiros, "os caras" que saem correndo, mas que desafiam a ordem estabelecida, o valor patrimonial. E nas alturas, onde deixam pelas cidades suas marcas individuais, em caligrafias e lugares inusitados, afirmam desse modo sua rebeldia contra o sistema, em sua expressão [anárquico-] artística.

Gross expõe na parede do MAM-SP essa ação poética urbana escrita em luz, instalando no corredor do museu a "caligrafia urbana" das ruas de São Paulo. Assim, com toda a sua força poética, instaura no museu um território simbólico da cidade que pulsa através do vermelho das luzes de neon, fazendo com que transborde um ambiente de calor, na luz artificial de metrópole contemporânea, embriagando os sentidos dos signos deslocados, com a cidade que adentra o museu sem pedir licença. Us Cara Fugiu Correndo é uma obra de Gross que funciona como rede de fluxos, criando novos agenciamentos de múltiplas identidades e significados deslocados de 
seu contexto, os quais geram sentido através de convergências [não racionais] desdobradas pelos encontros e circunstâncias imprevistas. Nesse processo que evoca uma operação do universo contemporâneo, em que cada contexto diferente coexiste ao mesmo tempo, podem surgir múltiplos territórios simultâneos que remetem à noção de fluidez da subjetividade, da identidade e da espacialidade descrita por Deleuze e Guattari em seu nomadismo rizomático ${ }^{83}$. E desse modo, em Us Cara Fugiu Correndo, os signos deslocados de seu contexto, nesse nomadismo rizomático, atuam como deslocamentos plástico-simbólicos criando territórios móveis que surgem da relação obra/cidade.

Us Cara Fugiu Correndo é a primeira obra em que Gross utiliza palavras escritas com luzes de neon. A escolha, o desenho e a realização das luzes surge na pesquisa para o Projeto Parede, do Museu de Arte Moderna de São Paulo, em 2000. Esse projeto, durante dez anos convidou artistas para intervir em determinada parede, que se estendia como um longo corredor na entrada do museu. $\mathrm{O}$ curador Tadeu Chiarelli comenta que o caráter temporário das intervenções "dinamizava aquele espaço 'neutro' do MAM, problematizando suas singularidades arquitetônicas e ideológicas" ${ }^{\prime 4}$. A ideia do projeto de Gross para esse espaço da parede veio de uma frase que a artista viu em uma pichação de rua. Desta frase, a partir das letras encontradas na rua, a artista iniciou uma pesquisa tipográfica do gesto e da luz

\footnotetext{
${ }^{83}$ A obra de Deleuze e Guattari é marcada por movimentos de relações múltiplas, coexistentes e complementares, como a metrópole e a comunicação em redes da sociedade e cultura contemporânea. Pensam e criam por rizomas, ou seja, constroem seu pensamento a partir do modelo do rizoma, em que os conceitos não estão hierarquizados, nem fazem parte de um ponto central, de poder ou referência, aos quais se deveria remeter. O rizoma, para eles, funciona em um sistema de encontros e agenciamentos, em uma cartografia de multiplicidades. Enquanto o rizoma é a cartografia, o mapa das multiplicidades, aberto, desmontável, reversível, sujeito a modificações permanentes, com múltiplas entradas, seu contrário que volta sempre ao mesmo é o modelo da árvore-raiz, que é o "decalque". Uma reprodução do mesmo ao infinito, que fala de uma estrutura linear, a qual estaria operando por hierarquia e pela centralidade. Contudo, apesar dessa aparente dualidade, esta proposta rizomática do pensamento de Deleuze busca contrapor, mas sem negar, o pensamento arborescente, ou seja, mesmo no rizoma podem existir segmentos que vão endurecer e se tornar árvore, ao mesmo tempo em que na árvore pode-se dar a constituição de um rizoma. Os autores utilizam o exemplo de sociedades primitivas que se remetem ao rizoma, ao nomadismo rizomático como estrutura social. No entanto têm arborescências dentro de si, e também, como nas sociedades capitalistas, que, apesar de identificadas com o modelo de arborificação, necessitam do rizoma e sua flexibilidade para existirem. Nas palavras de Deleuze: "Os processos são os devires, e estes não se julgam pelo resultado que os findaria, mas pela qualidade de seus cursos e pela potência de sua continuação [...]”. DELEUZE, Gilles. Conversações: 1972-1990. 2. ed. São Paulo: Editora 34, 2010.

${ }^{84}$ CHIARELLI, Tadeu. Catálogo da exposição Projeto Parede 10 anos - Museu de Arte Moderna de São Paulo. São Paulo: MAM, 2007.
} 
urbana, que culminou na escolha das lâmpadas de neon, no traçado do desenho fino e curvo das letras escritas à mão, escorrendo em um extenso corredor, seguindo uma linha horizontal. E para que isso fosse realizado, no processo de construção de $U s$ Cara Fugiu Correndo, a artista foi pesquisando o caminho técnico adequado a essa ideia de escrita/ação pictórica de uma luz urbana. No computador a artista elaborou todo o projeto, com o qual cortou as letras pela metade, aplicando outras letras embaixo, como se estivessem escorrendo. Assim, palavra e imagem, ao se estenderem por todo o corredor, deixam a marca [fugaz] da cidade na parede, deslocando o código visual, encontrado nas pichações urbanas de São Paulo, para dentro do museu. A linguagem da rua toma forma em uma caligrafia de neon, contaminando sensorialmente o ambiente com a força de um vermelho que remete à luminosidade das cidades, em seu discurso de rápido acesso. Gross comenta essa obra em uma entrevista ${ }^{85}$ :

[...] eu queria transformar isso numa coisa muito forte. Isso é uma frase de rua, tirada de uma pichação de rua. Eu não usei a própria imagem da pichação, que estava escrita com uma letra normal. Eu fiz o meu projeto e recortei as letras. De modo que o final das letras, embaixo, é cortada. Você nunca consegue completar, fica muito difícil de ler. A parte final foi retirada. Eu queria essa língua da rua dentro do museu, como na frase "Us cara fugiu correndo", e seus erros de português; Us, cara sem S, depois fugiu que também não está no plural, e correndo com esse gerúndio aí. Tudo errado.

Carmela Gross com essa obra inicia seus trabalhos de escrita luminosa, conjugando forma e conceito através de uma operação poética, em uma linguagem que se constrói na fala e no uso cotidiano. Na metrópole contemporânea, onde cada vez mais somos bombardeados por imagens e palavras sobrepostas ininterruptamente, em uma sequência sem fim e sem sentido, intermediadas por telões e luzes, Gross traz, em suas obras, uma dimensão poética crítica, utilizando o mesmo aparato tecnológico. Desse modo, a artista problematiza a vivência urbana através de jogos poéticos, sensoriais, que aproximam o sentir e o praticar simbólico da linguagem das cidades contemporâneas, ampliando seus sentidos críticos, perceptivos e metafóricos. Assim, através desse aparato usado pela artista, surge uma escrita plástico-poética.

\footnotetext{
${ }^{85}$ Entrevista com Carmela Gross concedida à autora. São Paulo, 13 de outubro de 2011, no ateliê da artista.
} 
Uma escrita plástica que, ao criar um dimensionar das representações da cidade [fixas ou fluidas], demarca e informa plasticamente, através dos mesmos processos eletrônicos de comunicação, características tanto sociais e políticas como estéticas e semióticas na leitura da cidade.

Nos diálogos com a cidade, Gross utiliza elementos dessa visualidade para construir jogos poéticos que, através da experiência [estética], direcionam o olhar do espectador para essa relação obra/cidade. Us Cara Fugiu Correndo, que inaugura essa nova linguagem plástica de Gross com as luzes de neon, faz surgir também uma nova relação poética da artista com a cidade. E, desse jogo poético que explora a relação de uma ação urbana poética, fugaz, através da luz vermelha fluorescente [com uma caligrafia de escrita à mão], em que não se lê a frase com clareza, nascem os diálogos poéticos de Gross com as cidades. E, a partir de então, esses diálogos seguem construindo novas obras, novos significados, novos mundos [novas relações entre arte e cidade]. São diálogos construídos a partir de imagens, elementos plásticos e signos da cidade [e do universo contemporâneo], ao longo dos anos 2000, subvertendo funções simbólicas, deslocando sentidos e criando novas relações poéticas através de obras instaladas nas cidades, em museus, e galerias de arte.

Esses jogos poéticos das palavras escritas com neon dão continuidade às esculturas feitas com luz, iniciadas por Gross em 1995. Contudo, essas obras luminosas, agora na linguagem como corpo luminoso atuando na externalidade do espaço, remetem a inúmeras reflexões na experiência do corpo/mente no espaço. Desse modo, diante da experiência fenomenológica que as cores ativam no ambiente, cada palavra instalada no espaço amplia seu sentido metafórico. Assim, através de uma palavra, ou frase, em forma de luz fluorescente, a artista instala uma experiência no espaço quase pictórica, rica em instigar ao mesmo tempo os sentidos plásticos e linguísticos. A provocação poética que embala o espectador com a força de uma única palavra, ou mais de uma, gera novos agenciamentos simbólicos e estéticos que falam, emocionam, criticam, revolucionam e transmutam o sentido poético de cada palavra instalada em seu contexto específico, gerando uma experiência singular do espectador com a obra e seu local específico [site specific]. Em Aurora, Gross propõe um diálogo de forte impacto poético onde é instalada. A obra ocupa o terceiro andar 
da Galeria Olido com a enorme palavra "Aurora" atravessando diagonalmente o espaço expositivo, escrita em uma caligrafia tortuosa de lâmpadas fluorescentes em tons rosados que envolve todo o ambiente. Aurora [Figura 45], que é uma instalação de grande impacto sensorial em São Paulo, dialoga ao mesmo tempo com a memória da cidade e com o espaço interno/externo de uma galeria de arte no centro de São Paulo. A relação da obra com o passado da cidade remete à memória da cidade onde, nas décadas de 1940 e 1950, havia o Cine Olido, reconhecidamente um dos pontos mais ilustres e concorridos dos grandes cinemas do centro de São Paulo. A escrita plástica de Aurora, que se apresenta na caligrafia, e na luz, de um singelo nome de moças [também de uma outra época], desloca sensório e conceitualmente os diversos significados da palavra "Aurora". Assim, cria um jogo poético com o tempo-espaço da memória de um lugar, contaminando-o de tons mágicos de pureza e esplendor, como se remetesse o espectador a um lugar do passado que contava [visualmente, sensorialmente] as histórias antigas da cidade. E, no mesmo sentido poético, a experiência continua do lado de fora do prédio da galeria. Pois, na fachada do prédio da galeria, através de uma grande janela, a obra se relaciona com a cidade, em um diálogo direto de palavra/luz rosa, fluorescente, tomando todo o espaço recortado da janela, regando-a de lirismo e pureza, como a Aurora, imortalizada pela marchinha de Carnaval de Mario Lago, em 1941.

Gross e sua instalação Aurora, em São Paulo, cria uma poética que pode ser experimentada através de múltiplas leituras, como a aurora de um lindo dia que nasce, e morre, na linguagem. E que, escrita como garatujas infantis, remete a experiências e descobertas impregnadas pelo sentimento de liberdade do universo das crianças. A artista escreve, inscreve, no espaço expositivo o nome próprio, o substantivo e a memória afetiva detonadora de processos significativos, individuais, na relação obra/espaço. Em uma vivência do espaço, que poderia despertar no espectador a poesia imbricada nos significados possíveis da palavra, e em sua luminosidade, que toca, fala e arrebata os sentidos, ativando no espectador uma gama [poética] infinita de experiências. Agnaldo Farias ${ }^{86}$ acrescenta:

\footnotetext{
${ }^{86}$ FARIAS, Agnaldo. AURORA. In: São Paulo das Mil e Uma Faces. São Paulo: Galeria Olido, 2004.
} 
Aurora é um exercício radical de poesia, uma demonstração do que pode um poeta, como Carmela Gross, que, ao invés do espaço bidimensional do papel, toma para si a volumetria do espaço ambiente. Se a palavra poética é aquela dotada de espessura, a palavra que não se curva às demandas da comunicação imediata, oferecendo, em lugar disso, por força de sua carne ampliada, como neste caso, outros sentidos, o que dizer de uma palavra que assume a nossa dimensão física, para atravessar uma sala como essa da Galeria Olido, interditando-a quase por completo? ${ }^{87}$

O material das letras da instalação Aurora também traz uma qualidade simbólica para sua escrita, pois é construída com a luz "grow lux", uma luz rosa que se coloca em estufas de plantas para que estas cresçam rapidamente. Ela não reproduz a luz solar, mas tem um componente de comprimento de ondas que é lido como se fosse o sol, ou seja, pode fazer fotossíntese de plantas e que também os peixes percebem como se fosse a luz solar. Nesse sentido solar, essa luz foi escolhida por Gross para escrever a palavra “Aurora”, pela primeira vez, no Rio de Janeiro, em uma sala do Paço Imperial. A artista comenta que o nome Aurora surgiu para aquele espaço, na cidade do Rio de Janeiro: “[...] vou desenhar aqui uma aurora, vou trazer a paisagem de fora para dentro. O Rio de Janeiro é a paisagem. E aí, no Rio de Janeiro, ela se referia à paisagem" ${ }^{\prime \prime 8}$.

Nesse diálogo com a cidade, a palavra "aurora", mais uma vez, desloca seu significado, para aludir metaforicamente à paisagem. Sua plasticidade evoca o sentido conceitual e sensorial da luz, cor, calor, de um nascer [crescer] do sol na cidade. Aurora que, através de uma luz artificial [grow lux] rosa, envolve todo o espaço e remete sensorialmente aos signos poéticos da experiência de uma cidade como o Rio de Janeiro. Gross apresenta assim, dentro do museu, a beleza natural [e artificial] da cidade em sua aurora, em seu despertar de luz, poesia cor-de-rosa, amorosa. Entretanto, apesar de todo o lirismo que o nome pode transmitir, para a artista, quando obra é instalada na Galeria Olido, em São Paulo, o contexto traz elementos socioculturais completamente diferentes. Gross comenta que a criação de Aurora, apesar de ter sido feita para o Rio de Janeiro [site specific], ao ser deslocada para São Paulo traz outros contextos e criam-se outros desdobramentos poéticos. Com suas

\footnotetext{
${ }^{87}$ FARIAS, Agnaldo. AURORA. In: São Paulo das Mil e Uma Faces. São Paulo: Galeria Olido, 2004.

${ }^{88}$ Entrevista com Carmela Gross concedida à autora. São Paulo, 13 de outubro de 2011, no ateliê da artista.
} 
palavras: “[...] Quando eu fiz aqui em São Paulo, ela na verdade é o nome das prostitutas do centro da cidade. Essa Galeria Olido que está no Largo do Paissandu é limite com a Rua Aurora, que é uma rua de prostituição" 89 .

Sendo assim, outra Aurora se relaciona com outro território, o centro da cidade de São Paulo. Uma relação sensorial se estabelece a partir da imensa janela no prédio da galeria [que fica aberta para a rua em frente ao Largo do Paissandu] envolvendo o entorno, ao gerar uma potente mistura da luz rosa das letras com as luzes do Largo e da Rua Aurora. Assim, aqui, Aurora [Figura 46] se relaciona e se contamina sensorialmente com esse espaço da cidade, onde sua luz rosa que se expande na rua, acolhendo o amarelo das luzes do seu entorno, se transmuta em roxo nessa mistura da obra com a cidade. Portanto, uma mesma palavra, escrita com a mesma luz, dependendo do local específico [site specific] passa a ativar outras forças e significados. Ou seja, diante da complexidade de cada um dos sites, diferentes dispositivos poéticos são ativados pela obra, os quais remetem aos múltiplos significados [possíveis] de uma palavra. Em São Paulo o nome Aurora, na complexidade do território urbano onde a obra é instalada, evocaria também a atividade de prostituição do centro da cidade. Nessa obra é interessante destacar as múltiplas possibilidades de deslocamentos simbólicos que atuam a cada montagem, em que uma palavra, um simples nome próprio, pode desencadear diferentes diálogos poéticos [estéticos e críticos], envolvendo o espectador/passante em um ambiente singular, dependendo do contexto de onde a obra está instalada.

E nesse desdobrar poético que se transmuta a cada novo contexto de seu local específico, Aurora, além dessas duas instalações no Rio de Janeiro e em São Paulo, teve outra montagem na Bienal de Moscou. Nessa Bienal, Gross instala a palavra "aurora" no vigésimo primeiro andar de um prédio da cidade, onde é possível vê-la a partir de fora, em uma grande extensão de visão na malha urbana. A artista comenta em uma entrevista ${ }^{90}$ que um fato inusitado ocorreu na experiência dessa montagem. Os operários, durante todo o processo da instalação da obra, apenas faziam o que a

\footnotetext{
${ }^{89}$ Entrevista com Carmela Gross concedida à autora. São Paulo, 13 de outubro de 2011, no ateliê da artista.

${ }^{90}$ Entrevista com Carmela Gross concedida à autora. São Paulo, 13 de outubro de 2011, no ateliê da artista.
} 
artista pedia, executando os desenhos sem ter noção do que estava sendo escrito. Porém, ao finalizar a obra, foram surpreendidos com o que visualizaram. Gross relata esse momento $^{91}$ :

[...] quando acendeu eles ficaram fascinados, porque daí eles conseguiram ler, e leram Aurora... porque é o nome do barco do Lenin, que era o barco de onde saíram os primeiros tiros da revolução de outubro. E aqueles operários que não falavam língua nenhuma, a não ser russo, conseguiram se comunicar por causa do nome...

A instalação de Aurora, aqui [Figura 47], outra vez, se comunica com o espectador ativando, em cada um, um território simbólico próprio, a partir de um nome, que não é só completamente familiar a eles, mas que também agencia todo um campo de representação simbólica de identidade com sua cultura, sua história. $\mathrm{O}$ desdobramento poético do nome Aurora que, ao conseguir se comunicar diretamente com eles [e seu contexto histórico], possibilita àqueles operários [e também o povo da Rússia] dialogar com sua história, sua memória. Assim, a partir de um significado que se constitui em um contexto coletivo surge a possibilidade de que, tanto os operários como outros cidadãos russos, ao se relacionar com o nome podem construir um sentido individual. Desse modo, ao gerar trocas de subjetividades entre a obra e o espectador, esse trabalho de Gross pôde estabelecer jogos estéticos e conceituais no dialogar com a cidade. A artista acrescenta que a obra parecia uma experiência bastante impactante para o público de lá. Com suas palavras: "Eles gostavam muito, passavam o dia tirando fotografias. O público só ia para tirar fotografias na frente do Aurora. De noite era muito lindo",92.

Nessa multiplicidade simbólica de Aurora, o trabalho oferece uma experiência estética que pode atuar em constante mutação de forças e fluxos poéticos, gerando novos territórios poéticos. No fluxo da multiplicidade desse devir artístico que a obra propõe, territórios históricos e subjetivos agem como dispositivos poéticos que, ativados pela memória desses códigos, criam novos movimentos relacionais entre os signos, e sentidos. E, desse modo, a obra ativa fluxos poéticos móveis dependendo do

\footnotetext{
${ }^{91}$ Entrevista com Carmela Gross concedida à autora. São Paulo, 13 de outubro de 2011, no ateliê da artista.

${ }_{92}$ Entrevista com Carmela Gross concedida à autora. São Paulo, 13 de outubro de 2011, no ateliê da artista.
} 
contexto onde é instalada. E, nesse contexto, o conceito de territorialização de Deleuze e Guattari pode ser ampliado para a leitura dessas novas relações simbólicas que se estabelecem no fruir com a obra. Em Aurora e outras obras de Gross esses agenciamentos poéticos que se transmutam a cada novo contexto, nova percepção, ampliam e ressignificam essa noção de território ${ }^{93}$, que é citado a seguir por Guattari:

[...] O território pode ser tanto relativo a um espaço vivido quanto a um sistema percebido no seio do qual um sujeito se sente "em casa". O território é sinônimo de apropriação, de subjetivação fechada sobre si mesma. Ele é o conjunto de projetos e representações aos quais vai desembocar, pragmaticamente, toda uma série de comportamentos, de investimentos, nos tempos e nos espaços sociais, culturais, estéticos, cognitivos. ${ }^{94}$

Esses novos agenciamentos entre signos e sentidos, que são ativados pela poética de Gross, geram também deslocamentos simbólicos de apropriação e subjetivação de territórios entre a cidade e o museu. A artista escreve, desenha, inscreve, pinta e dialoga com suas palavras, alocadas em espaços de museus, galerias, e em intervenções nos espaços urbanos e arquitetônicos das cidades. Agnaldo Farias contribui com sua reflexão sobre as "palavras" de Gross:

Como nos demonstra a artista, basta uma única palavra, desde que revisitada sob um ângulo original, reescrita em relação à arquitetura ou ao próprio espaço da cidade, para que ela se renove por completo, para que passe a verter por novos significados, inaugurando mundos e dias novos. ${ }^{95}$

A poética de Gross na cidade propõe uma interação perceptiva, muitas vezes crítica, não somente através de palavras ou luzes de neon, mas a partir de imagens, signos poéticos ou representações da cidade como fluxos móveis, que estabelecem novas relações de sentido, ampliando percepções e/ou reflexões, dependendo do contexto onde é instalada. Na amplitude de sua poética, as obras de Gross promovem diferentes experiências nas cidades, ora geram instâncias de reflexão, em outras uma

\footnotetext{
${ }^{93}$ Deleuze e Guattari, em sua filosofia, incluem mudanças entre as diferentes naturezas desse conceito, as quais tratam de diferentes e sobrepostas interpretações, em que uma se coloca por sobre a outra e para além de todas estas, já que a noção de território para eles tem outro conteúdo.

${ }^{94}$ GUATTARI, Félix; ROLNIK, Suely. Micropolítica: cartografias do desejo. Petrópolis, RJ: Vozes, 1996.

${ }^{95}$ FARIAS, Agnaldo. AURORA. In: São Paulo das Mil e Uma Faces. São Paulo: Galeria Olido, 2004.
} 
intensa experiência sensorial, fenomenológica, ou mesmo a silenciosa integração da obra, na vivência do espectador/passante com a cidade. Entretanto, todas estabelecem relações plásticas com o ambiente, integrando sua poética em uma territorialidade móvel, que possibilita constantes agenciamentos de sentidos e representações simbólicas. Ou seja, a partir de suas obras nas cidades surgem ressignificações tanto no campo artístico, estético, como no espaço urbano de convivência. Gross propõe no espaço-tempo [fugaz] das metrópoles um jogo poético como uma nova experiência de cidade. Seja esta experiência ativada, ou não, pelo diálogo estético, sempre haverá uma provocação que instiga a um novo olhar, um novo vivenciar da cidade.

A primeira intervenção urbana de Gross foi uma escultura, A Negra [Figuras 48 e 49], instalada por dois meses, em 1997, na Avenida Paulista, em São Paulo. A obra fez parte de um projeto $^{96}$ chamado Diversidade da Escultura Brasileira Contemporânea, em que vinte intervenções de artistas, ao longo da Avenida Paulista, estabelecem um diálogo com a cidade de São Paulo. A Negra é uma escultura de um enorme vulto ereto de tule preto, que alude a uma figura fantasmagórica, uma coisa transparente e indevassável, em um vestir sem corpo, expondo toda uma potência de aparição. A escultura, ao ser construída em uma escala de dimensão urbana, sem uma forma reconhecível, e sobre rodas, sem indicação de movimento ou itinerário, provoca estranhamento ao transgredir o território urbano.

De fato Gross, através de uma arte efêmera que quer dialogar com a vida cotidiana nas ruas das cidades, propõe um questionamento sobre essa possibilidade de se experimentar poeticamente a cidade, em uma atitude que evoca a intenção conceitual experimental do final dos anos 1960. Os artistas, no Brasil daquele período [de uma ditadura militar], embrenhados no imaginário urbano, abriam caminho para propostas artísticas cada vez mais radicais, tanto estética como politicamente. Carmela Gross é uma artista que se formou nessa geração experimental, que nos anos 1960 e 1970 buscou criar novas ações e procedimentos para discutir questões políticas e ampliar conceitos estéticos, comportamentais e ambientais. A interferência

\footnotetext{
${ }^{96} \mathrm{O}$ vivenciar a cidade através da arte faz parte do conceito de um projeto que o Itaú Cultural realiza em 1997, chamado Diversidade da Escultura Brasileira Contemporânea, em que procura estabelecer um diálogo com a cidade de São Paulo a partir de vinte intervenções de artistas ao longo da Avenida Paulista, com obras que ficaram na avenida por dois meses.
} 
dos artistas nas ruas das cidades, naquele momento, ressalta o cotidiano, o banal, o consumo, a hipocrisia e o silêncio opressor, ampliando o campo artístico até o limite entre arte e vida, construindo uma nova visão de arte e política nos espaços urbanos.

Entretanto Gross, apesar de dialogar com essas ações, tem seu modo particular de dialogar com a cidade. E, em outro contexto histórico [e cidade], cria sua intervenção a partir de um objeto escultórico. Assim, um lugar de passagem e de troca com o ambiente possibilita o ativar de uma multiplicidade de territórios poéticos a quem se relacionar com a obra na cidade, no cotidiano apressado, de quem passa por essa avenida conturbada de São Paulo. O caos urbano, segundo Rem Koolhaas ${ }^{97}$, não é uma antevisão do futuro, pelo contrário, é o presente progressivo da cidade desorganizada. $\mathrm{O}$ futuro da cidade já é a própria cidade contemporânea que se torna difícil de compreender, pela sua particularidade, complexidade e escala adotada. Uma megaescala que ultrapassa os limites da legibilidade humana é o que Koolhaas define como conceito de Bigness. E é nessa megaescala de metrópole que o autor [e arquiteto] define o fenômeno contemporâneo. Nesse sentido, a intervenção das obras ao longo da Avenida Paulista explora a particularidade desse fenômeno contemporâneo conceituado por Koolhaas, ou seja, propõe um diálogo estético ao se relacionar com a problemática das metrópoles contemporâneas [como São Paulo], que ultrapassa os limites humanos de convivência, em suas escalas verticais na arquitetura e no caos instalado pela escala humana.

No fluxo dessa complexidade de cidade, A Negra surge como ação poética que promove um diálogo de formas plásticas a partir de um objeto escultórico que, ao envolver o espectador/passante na possibilidade da surpresa de um novo olhar, pode gerar estranhamentos no cotidiano que amplia visões de mundos, do imaginário urbano e da própria cidade. Desse modo, no devir da metrópole contemporânea, a obra amplia o campo da arte, dialogando com o experimentar, o vivenciar da cidade, a partir de outros encontros e agenciamentos simbólicos. E ativa assim, nesse percurso com as diversas obras ao longo da avenida, uma multiplicidade de visões, reflexões e relações poéticas. Gross cria com sua obra A Negra uma arte de caráter volátil, espontânea, improvisada, na qual o que importa é a experiência e a

\footnotetext{
${ }^{97}$ KOOLHAAS, Rem; MAU, Bruce. $S, M, L, X L-$ O.M.A. New York: The Monacelli Press, 1995.
} 
possibilidade de interferir no espaço urbano das metrópoles contemporâneas como um meio de se comunicar com o transeunte, extrapolando os limites da permanência diante dos deslocamentos físicos e poéticos.

Lilian Amaral ${ }^{98}$, em seus estudos sobre as trocas que existiriam nas cidades contemporâneas, fala de "situações de pracialidade" em diferentes locais diferentes dos largos e das praças, os quais estariam simbolicamente se apropriando da noção de praça ao deslocar sua funcionalidade de convivência coletiva para as grandes avenidas, como é o caso da Avenida Paulista de São Paulo. Portanto, a noção de praça em uma cidade como São Paulo, deslocada para uma avenida, cumpre a mesma função simbólica, revelando os deslocamentos das metrópoles contemporâneas. Esses deslocamentos falam do fluxo migratório de signos de convivências, das antigas praças e seus coretos [ainda presentes nas pequenas cidades] para as grandes avenidas, evocando nestas o lugar simbólico do encontro e o lugar para se praticar a experiência da cidade. Lilian Amaral acredita que a praça, como espaço, não é somente forma ou paisagem, nem cenário ou palco para as ações humanas, mas um conjunto de sistema relacional de existências que se situam no tempo-espaço, atuando na construção da esfera pública da vida na cidade.

Nesse contexto simbólico de praça, Gross cria em Laguna uma intervenção permanente que é a obra Fonte/Foz [Figura 50]. Essa obra faz parte de um projeto de intervenções urbanas feitas em locais de fronteira do Brasil com países do Mercosul (Argentina, Paraguai e Uruguai). O projeto, que é chamado de Fronteiras $^{99}$, foi um convite para que Gross e outros artistas explorassem a noção de fronteira em locais específicos $^{100}$. A implantação dos trabalhos foi desdobrada em etapas entre 1999 e 2001, e hoje eles se estendem ao longo dos limites extremos dos estados de Mato

\footnotetext{
98 BARBOSA, Ana Mae; AMARAL, Lilian (Org.). Interterritorialidade: mídias, contextos e educação. São Paulo: Editora Senac São Paulo; Edições SESC SP, 2008.

${ }^{99}$ O projeto, que é chamado Fronteiras, surgiu com um convite feito pelo Itaú Cultural, em 1998, para que um grupo de artistas desenvolvesse obras permanentes em escala ambiental. A proposta foi explorar nelas livremente a noção de fronteira, para que essas obras constituíssem um acervo permanente de obras públicas, na extensão territorial que abrange toda a linha de fronteira com o Mercosul.

${ }^{100} \mathrm{O}$ início do projeto foi o momento de definição das regiões de preferência dos artistas. Quando foram construindo, pesquisando e finalizando suas propostas, tanto do ponto de vista formal, conceitual e técnico, como em relação aos trâmites administrativos e jurídicos necessários à implementação das obras nas regiões escolhidas.
} 
Grosso do Sul, Santa Catarina e Rio Grande do Sul, em uma rede de pequenos municípios e cidades de porte médio no interior do país. Entretanto, a obra de Gross foi instalada em uma exceção a essa regra, feita à cidade de Laguna, situada no litoral de Santa Catarina. Essa localidade era significativa para o projeto Fronteiras por sua importância histórica ${ }^{101}$. De acordo com as possibilidades do projeto, Gross escolheu uma cidade onde poderia realizar uma obra que tivesse uma função urbana de "praça". A artista, ao comentar esse projeto, enfatiza que não faria um trabalho no campo, longe da cidade e de um contexto urbano. Portanto, ao realizar uma obra permanente que iria intervir na cidade, a artista tinha como intenção criar um espaço de uso coletivo para a cidade, em que o trabalho entrasse na escala da cidade, sem a determinação de ser cultuada, identificada como a obra de um artista, mas com a possibilidade de múltiplos usos cotidianos no contexto urbano.

E essa mesma intenção norteou seu projeto para a V Bienal do Mercosul, para a qual projetou e realizou uma obra site specific, Cascata [Figura 51], em 2001. A obra é uma intervenção permanente na cidade de Porto Alegre. O espaço da cidade em que foi instalada a obra tem dois níveis, onde há uma separação entre o nível do rio e o da estrada, que chamam de perimetral. Assim, Cascata, uma estrutura metálica preenchida de concreto, une esses dois níveis através de degraus irregulares que se dispõem no chão como se fossem cartas de baralho, espalhadas. Entretanto, para a artista, Cascata é simplesmente uma escada, no sentido de que, como na praça de Fonte/Foz, possa proporcionar um lugar de encontro na cidade, como uma delicadeza urbana que promova o reunir coletivo na experiência de cidade. Nas palavras da artista:

Praça também como a ideia de fronteira, mas queria o sentido social de encontro que tem a praça. Tenho muito claro que não quero fazer uma escultura que seja monumento de si mesma. Então, queria que houvesse essa mistura entre o uso, a não identidade do artista, a não determinação de uma obra para ser cultuada. Isso aqui pode se encher de barraquinha e virar uma festa, pode virar um labirinto para criança brincar, pode ter múltiplos usos. E que se as pessoas não saibam que foi um artista que

\footnotetext{
${ }^{101}$ Essa localidade era significativa para o projeto Fronteiras por sua importância histórica, como centro de muitos acontecimentos envolvendo a nação, e os limites fronteiriços do Brasil, desde sua fundação em 1627. E também por ser um marco histórico do Tratado de Tordesilhas, firmado em 1494 entre Espanha e Portugal, para delimitar a posse das terras americanas entre estas, depois da primeira viagem de Colombo.
} 
fez, e qualquer coisa desse tipo, tudo bem. Eu acho que esse silenciar, na escala da cidade, é muito bonito. Foi o que eu fiz ali [em Laguna] e na "Cascata" da Bienal do Mercosul. $^{102}$

Essa "apropriação", integração de sua obra nas cidades como fluxos de ocupação espontânea, fomenta a criação de espaços [provisórios] de convivência da população urbana problematizando questões do urbanismo, as quais remetem a discussões sobre a categoria de espaço público utilizada pelas políticas urbanas, analisadas por Adrián Gorelik ${ }^{103}$. Nas palavras do autor:

Finalmente, se poderia dizer que as políticas urbanas utilizaram a categoria espaço público em duplo sentido: por uma parte, em sentido muito tradicional e operativo, como o espaço aberto da cidade (as ruas e as praças), sem mais conteúdo teórico do que o suposto de que é no espaço aberto que a sociedade se reúne e reconhece; por outra parte, agregando automaticamente nesse espaço aberto todas as qualidades sociais e políticas que as teorias do espaço público colocam em circulação. Nesse sentido, por obra e graça do "romance do espaço público", desenhar uma pracinha já não era desenhar uma pracinha, mas estar construindo os pilares da sociabilidade democrática. Assim se justificaram como progressistas ideias urbanísticas que simplesmente retomaram com bastante pobreza de meios os modelos urbanos do século 19, retomando também o princípio do funcionamento de mercado da cidade, como se a constatação teórica de que para existir espaço público tem que haver mercado, garantisse a constatação prática inversa, de que onde a cidade funcionar como mercado haverá espaço público. ${ }^{104}$

Portanto, nesse contexto ideológico, a inserção dessas obras de Gross nos espaços urbanos das cidades joga com elementos estéticos, sociais e políticos, que se tencionam mutuamente, e que se destacam, a partir da obra, como a possibilidade de um espaço público que pode ser vivenciado provisoriamente como território poético ocupado, compartilhado. E nesse sentido a artista na cidade de Laguna propõe sua "praça", à beira-mar, com Fonte/Foz. A obra é uma espécie de desenho em escala gigantesca, que se expande no chão da cidade, tomando a forma insular de uma praça no meio do asfalto, à beira-mar. A artista preenche uma área de aproximadamente 1.600 metros, usando a técnica do mosaico com pedras portuguesas, muito utilizado

\footnotetext{
${ }^{102}$ Entrevista com Carmela Gross concedida à autora. São Paulo, 13 de outubro de 2011, no ateliê da artista.

${ }^{103}$ GORELIK, Adrián. O romance do espaço público. Arte \& Ensaios, Rio de Janeiro, (EBA-UFRJ), n. 17, págs. 189-205, 2008.

${ }^{104}$ GORELIK, Adrián. O romance do espaço público. Arte \& Ensaios, Rio de Janeiro (EBA-UFRJ), n. 17, págs. 204-205, 2008.
} 
no Brasil [e em Portugal]. E com esse material constrói um desenho com linhas concêntricas, que se sucedem em ritmos que se expandem continuamente, como irradiações ondulares em toda a superfície. A visão da obra convida a uma apropriação do plano horizontal da cidade de Laguna, que se relaciona poética e plasticamente com os elementos da natureza ali presentes, ecoando sua serialidade em ritmos orgânicos, presentes nas marcas que o vento deixa nas águas, nas dunas. A partir de um ponto elevado, a poucos metros da obra, é possível perceber a obra como um desenho bidimensional. Isto é, visto de cima, ao se eliminar a verticalidade da arquitetura da cidade, surge o desenho da obra com seus movimentos em ondas no chão, que funcionam visualmente como efeito cinético. Contudo, ao se caminhar dentro da obra, outra percepção diferente é ativada. Pois o chão, mesmo sendo absolutamente plano, quando o espectador/passante se desloca pela obra pode perceber outras imagens e sensações no chão, que parece ondular em desníveis sob seus passos. Desse modo, a obra explora uma experiência fenomenológica no espaço funcional da cidade, que instiga novos sentidos perceptivos do espaço.

A poética de Gross, para Sônia Salzstein ${ }^{105}$, busca intervir na dimensão linguística dos trabalhos, como é o caso da obra em questão, que revela seu vocabulário conceitual na literalidade dos materiais e na representação plástica [metafórica] presente nos diálogos, entre a operação formal dos trabalhos e sua carga simbólica. De fato, o desenho que se forma no chão como ondas, ou dunas de areia, dialoga com os arredores da "praça". Contudo, o passado da cidade e sua importância como marco histórico da colônia portuguesa também pode ser percebido em outro diálogo com o material das pedras portuguesas, em que revela a relação entre essa operação formal e a carga simbólica que a autora comenta. Assim, na experiência da "praça" de Gross se relaciona todo um contexto de singularidade daquele lugar, no qual coabitam, em um mesmo lugar, múltiplas dimensões [simbólica e plástica] de ação e agenciamento poético [histórico], possibilitando a criação de múltiplos territórios poéticos. Fonte/Foz, ao delimitar um território físico no espaço urbano da cidade de Laguna, propõe jogos poéticos como elementos fenomenológicos que, ao

\footnotetext{
${ }^{105}$ SALZSTEIN, Sônia (Org.). Fronteiras. São Paulo: Itaú Cultural; Rio de Janeiro: Contra Capa, 2005. Nesse livro, Sônia Salzstein entrevista os artistas e escreve vários ensaios sobre o projeto Fronteiras.
} 
ativar uma experiência estética, possibilitam novos agenciamentos de percepções, reflexões e ações, em um novo lugar do reunir coletivo. E, nesse deslocamento de sentido, a obra em sua "intenção de praça" atuaria como um recorte simbólico na cartografia da cidade de Laguna. E, segundo Salzstein, esse recorte criaria uma espécie de recesso no espaço temporal [físico e sociocultural] do lugar. Nas palavras de Salzstein:

É um lugar de inconstância, que relativiza incessantemente a posição do observador perante o espaço da cidade, que o insta a um cíclico ir e vir e que o remete alternadamente ao campo mental do "desenho" e à percepção da fenomenologia da paisagem. É como se o trabalho, enfim, usasse uma forma cara à tradição clássica da cidade para propriamente neutralizá-la. ${ }^{106}$

Carmela Gross, ao introduzir obras como Fonte/Foz e Cascata no espaço urbano das cidades envolvidas, promove uma interação cotidiana, espontânea, do circular e do absorver a obra no dia a dia dos passantes, de modo que, nessa interação cotidiana, a dimensão artística da obra pode até passar despercebida. Isto é, essas obras de Gross ativam no cotidiano da cidade uma experiência com a obra que envolve mais um reunir e um vivenciar a cidade do que apenas um contemplar estético, passivo. Assim, Gross estabelece seu diálogo poético no experienciar a cidade integrada no seu contexto, localização e arquitetura do lugar, e no contato mútuo entre pessoas. Diante das problemáticas de cada site specific, a escrita plástica de Gross estabelece uma multiplicidade de diálogos estéticos e conceituais. Sua poética trata de uma dimensão discursiva específica do lugar onde a obra é instalada, revelando uma linearidade que remete ao desenho. Cada trabalho revela sua singular potência, como uma territorialidade poética que possibilita a experiência de novos encontros entre significações, percepções, sentimentos e sentidos. Através desses novos agenciamentos perceptivos e simbólicos, novas redes de relações são estabelecidas entre diferentes instâncias urbanas [arquitetura, memória, política e suas questões espaciais, socioculturais].

\footnotetext{
${ }^{106}$ SALZSTEIN, Sônia (Org.). Fronteiras. São Paulo: Itaú Cultural; Rio de Janeiro: Contra Capa, 2005.
} 
Uma obra interessante de analisar nesse contexto de site specific é a intervenção Buracos [Figura 52], que a artista realiza na primeira fase do projeto de intervenções urbanas na cidade de São Paulo, Arte/Cidade 1: Cidade sem Janelas, em 1994. A primeira fase do projeto ocorreu em um espaço fechado de 1887 , no prédio vazio e deteriorado de um antigo matadouro da Vila Mariana, Zona Sul da cidade, que há muito tempo deixava de fazer parte da cidade ${ }^{107}$. O projeto e suas três fases distintas de intervenções, até 1997, buscaram levar em consideração o local, a inserção arquitetônica, a escala urbana, a complexidade das situações e os componentes sociais e políticos das regiões onde seriam instaladas as obras. Segundo seu organizador e curador, Nelson Brissac, o Arte/Cidade se caracterizou por ocupar edificações em momentos de transição, ou seja, quando seus usos tradicionais estavam sendo redefinidos para futuras utilizações. O prédio do antigo matadouro era uma dependência pública já destinada a um posterior uso cultural, e as outras edificações também já tinham seus destinos definidos: um seria transformado em um centro de cultura, em outro haveria a construção de um conjunto de apartamentos, remodelando a edificação de uma antiga fábrica Matarazzo. E o prédio da Eletropaulo, um importante marco do patrimônio histórico, já estava vendido para a construção de um shopping center. Cada projeto de intervenção aconteceu em um momento importante, e apropriado, à discussão sobre esses processos de conversão desses espaços urbanos ${ }^{108}$.

${ }^{107}$ Citando Brissac: "O espaço estava vazio, deteriorado, era sombrio e altamente sugestivo. Quinze artistas participaram, empregando meios diferentes - vídeo, escultura, performance, instalações. De acordo com Agnaldo Farias, cocurador da mostra, a cidade não devia ser o tema do evento, mas, antes, o seu suporte. Como explica Farias, os artistas não tratariam da cidade como algo externo ao seu trabalho, mas incorporariam elementos da cidade à sua própria linguagem artística". BRISSAC PEIXOTO, Nelson (Org.). Intervenções urbanas: Arte/Cidade. São Paulo: Editora Senac São Paulo, 2002, pág. 286.

${ }^{108}$ Entretanto, Brissac ${ }^{108}$ comenta que o projeto não se imbricou efetivamente nos processos de produção e administração das cidades, e por isso não foi possível explorar devidamente todas as relações com a dinâmica da cidade e conquistar ganhos permanentes para essas áreas abandonadas da cidade de São Paulo. Com suas palavras: "No geral, as intervenções tenderam a levar mais em consideração o sítio, a inserção arquitetônica, a escala urbana, a complexidade das situações e os componentes sociais e políticos - embora o projeto, dadas as inevitáveis limitações de uma proposta sem precedentes, não consolidada perante a opinião pública, não tenha podido explorar devidamente todas as possíveis relações com a dinâmica da cidade e as operações (revitalização, implantação de novos sistemas de transportes e comunicação, reconstrução e reordenamento em escala urbana) previstas ou em andamento para as diversas áreas em que ocorreu". BRISSAC PEIXOTO, Nelson (Org.). Intervenções urbanas: Arte/Cidade. São Paulo: Editora Senac São Paulo, 2002, pág. 14. 
Brissac afirma que estamos entrando em uma era pós-arquitetônica, em que a capacidade tradicional de organizar o espaço e o tempo entra em conflito com o poder dos meios de comunicação, ou seja, o contato virtual torna-se a nova referência do tempo-espaço das trocas humanas, anulando noções como o próximo e o distante. Assim, o próprio espaço urbano estaria perdendo sua realidade topogeográfica em uma cidade sem urbanismo, onde o cinematismo da metrópole que, desprovida de localização, se constitui em diversas vias de transportes de alta velocidade, pontes e viadutos circulando em um eixo desordenado e fragmentado dos vazios da urbe contemporânea, onde o tecido urbano se esgarça em fraturas que rasgam a cidade, criando um estilhaçamento. Estariam surgindo várias áreas desconectadas, nas quais uma série de vazios constitui uma cidade que se expande em intervalos e desmaterialização. Uma “desurbanização" da cidade que estaria avançando, deixando um vácuo atrás de si, em que o desenho tradicional é subvertido e o que estaria à margem se torna central. E toda essa "desurbanização", segundo Brissac, seria o resultado da aceleração dos deslocamentos, pelos quais enormes zonas abandonadas convivem com áreas de ocupação intensa e desordenada. E, sendo assim, estaria havendo nas cidades uma aceleração também na imagem arquitetônica, que reflete nela as sucessivas mudanças de estilos, revelando uma arquitetura em movimento.

Nesse contexto de cidade, Gross, com sua intervenção Buracos, traz simbolicamente a cidade de São Paulo, seu presente/passado, para dentro do prédio do antigo matadouro, no qual explora plasticamente um movimento de demarcação pesada na arquitetura do espaço destinado a ela. A artista recorta e mapeia todo o chão com vários buracos, de formatos irregulares, que formam uma precisa trama de linhas em todo o espaço do chão, no qual cada escavação é desenhada com proporções rigorosamente determinadas. E nas paredes da sala a artista cobre com painéis de tecido imagens que reproduzem as perfurações. Surge então uma cartografia dos vazios que, organizados meticulosamente como os sistemas de medida existentes nos matadouros, remetem a questões do tecido urbano das cidades contemporâneas e suas áreas fragmentadas, abandonadas como ilhas de vazio, espalhadas pelas tramas urbanas da metrópole de São Paulo. Essa obra de Gross explora a linearidade do pensamento do desenho que recorta o ambiente em linhas de 
buracos no chão e manchas na paredes através de ritmos equilibrados, harmonizando, dando um contorno que totaliza e integra a obra no espaço arquitetônico do prédio do matadouro, ativando sua função simbólica, que remete a um ambiente de desolação, destruição, morte. Sua escavação deixa à mostra toda a brutalidade de materiais, como resíduos de concreto, cimento, pedras e pó, evocando resíduos de um passado contido em cada grau de pedra e areia escavada. E que, através dos quais, retira um sentido, uma reflexão, que se corporifica no vazio cheio da memória do local e da cidade. Brissac comenta essa obra de Gross:

Enquanto os buracos no chão atuam como janelas negativas que se abrem para dentro, engolindo o espaço, suas reproduções nos painéis agora surgem como janelas metafísicas, desenhando-se e despregando-se das paredes, invadindo a sala, assombrando o lugar. Paradoxalmente, graças a esses buracos inquietantes o site se contrai e se recupera, adquirindo unidade e identidade novas. O espectador descobre então que o espaço do matadouro, à primeira vista considerado abandonado e morto, agora parece vivo, pulsando e respirando, esvaziando-se e enchendo-se. ${ }^{109}$

A proposta de Nelson Brissac no Arte/Cidade era explorar a cidade de São Paulo como um campo em que se poderia tratar de diversas questões sobre a cidade e a arte. $\mathrm{O}$ autor esclarece:

As intervenções promovidas por Arte/Cidade são, porém, investigativas e críticas, especulações essencialmente artísticas sobre a natureza e o destino daquelas áreas da cidade. Não visavam determinar o perfil definitivo dos lugares. Nem efetivar reformas estruturais na trama urbana, tarefa que cabe aos órgãos administrativos da cidade. Aqui se tratava de intensificar a percepção desses espaços, trazer à tona significados ocultos ou esquecidos, apontar para novas possibilidades e usos, redimensionar sua organização estrutural, sugerir novas e inusitadas configurações.

[...] As megacidades são o horizonte da contemporaneidade. Não se pode compreender a criação artística e arquitetônica atual independentemente das grandes escalas da metrópole, aliadas à perda das referências históricas e locais que provocam. ${ }^{110}$

Portanto, Brissac acredita que por conta desse horizonte de contemporaneidade, existente nessas megacidades, muitos projetos artísticos foram desenvolvidos nos últimos anos nas grandes cidades contemporâneas. Projetos estes que questionam

\footnotetext{
${ }^{109}$ BRISSAC PEIXOTO, Nelson (Org.). Intervenções urbanas: Arte/Cidade. São Paulo: Editora Senac São Paulo, 2002, pág. 287.

${ }^{110}$ BRISSAC PEIXOTO, Nelson (Org.). Intervenções urbanas: Arte/Cidade. São Paulo: Editora Senac São Paulo, 2002, pág. 13.
} 
processos decorrentes da reconfiguração global do poder econômico, em operações de revitalização e desenvolvimento urbano que se tornam cada vez mais complexas. Problematizam, assim, através de um deslocamento das linguagens e procedimentos existentes, o estatuto e os procedimentos convencionais tanto da arquitetura e do urbanismo como da arte. A metrópole contemporânea, segundo Nelson Brissac, se constitui por meio de fragmentos cujo nexo recíproco não se pode captar facilmente ou há muito se perdeu. Ele adverte que o monumento hoje acentua as contradições da cidade, o qual tem uma função sociocultural completamente diferente de um monumento em uma cidade gótica, onde uma catedral, uma praça fazia parte, era integrada à cidade. No caso dos monumentos, hoje eles não estão integrados à cidade, nem encarados como fundamentais para a experiência de cidade, pois muitas vezes estão alocados como meros elementos cenográficos. E o fato de que a cidade contemporânea aparente estar sem um perfil integrado, em uma falta de centralidade, o autor considera que a arte poderia dar conta desse lugar. Isto é, através das manifestações artísticas nas cidades se poderia estabelecer um diálogo que exploraria esse território desgastado, fragmentado, do universo contemporâneo, que para o autor é um mundo marcado pelo nomadismo, a multiplicidade, impermanência e a simultaneidade.

Diante desse contexto, a poética de Gross ecoa nas cidades como novas possibilidades de agenciamentos entre signos e sentidos urbanos, em fluxos poéticos, a cada obra. Uma ocupação física integrada ao ir e vir dos passantes, como Fonte/Foz e Cascata, ativa no reunir o agregar e o se apropriar de um espaço urbano que pode se desdobrar em um território poético que problematiza a categoria de espaço público, ampliando o campo da arte e do urbanismo em seu diálogo com o social. Entretanto, em Buracos, Gross estabelece outro dialogar com a cidade, obra em que o site surge como um lugar de ideias. Isto é, ativa a partir da experiência estética o fluir das relações entre discursos e conceitos, fomentando uma discussão crítica sobre a cidade. Desse modo, Gross convida ao debate novos territórios de significação, que agenciam sentidos provisórios de existência nas diversas possibilidades de se construir uma cartografia poética, urbana, em sua dimensão sociocultural e política. 
A poética de Gross se aproxima do pensamento de Jacques Rancière ${ }^{111}$, quando este diz que a arte, e seus poderes subversivos, continua reafirmando sua vocação política na contemporaneidade. O autor enumera diversas manifestações com potencial político que surgem nos nossos dias, através dos diálogos estabelecidos entre obra de arte e cidade. Rancière exemplifica obras que se assemelham às de Gross [como em Eu Sou Dolores, entre outras]: "discretos signos de neon que, destinados a criar um novo entorno, detonam assim novas relações sociais" ${ } 112$.

O potencial político nos diálogos de Gross com a cidade opera realmente como "discretos" dispositivos poéticos que, em sua sutileza, desperta em alguns alguma emoção, reflexão, mas que, sem dúvida, passa despercebido por muitos. Porém sua subjetividade latente, em obras como Eu Sou Dolores ${ }^{113}$, a artista mescla conceito e sensorialidade ao estabelecer uma narrativa plástica como um ensaio poético das relações sociais entre territórios urbanos e seus contextos políticos e culturais. Essa obra de Gross fez parte do projeto Arte/Cidade Zona Leste, em 2002, outra iniciativa de Nelson Brissac. A proposta foi uma série de intervenções urbanas em espaços "abandonados", marginalizados, de uma região que antes abarcara toda uma estrutura socioeconômica industrial da cidade, situada na Zona Leste da cidade de São Paulo. Esse Arte/Cidade tratou da relação com a Zona Leste da cidade, de modo que alguns artistas fizeram intervenções nas ruas e outros ocuparam os escombros desse prédio, uma antiga fabrica abandonada [o atual prédio do SESC Belenzinho], mas que na ocasião era apenas uma carcaça de coisas velhas e de paredes em ruínas, como se fossem escombros.

Nesse Arte/Cidade Gross participa com uma frase escrita com lâmpadas fluorescentes, em um grande painel [25 $\mathrm{m}$ de comprimento por $2 \mathrm{~m}$ de largura] instalado no prédio [em ruínas] da antiga fábrica. A frase, escrita com grandes letras, é alocada dentro e fora do prédio, onde a palavra $E u$ fica do lado de fora [por um vão de janela] e Sou Dolores dentro do prédio. Sendo assim, se vê o $E u$ do lado de fora e só do lado de dentro se pode ver o Sou Dolores [Figura 54]. Para Gross, essa parte

\footnotetext{
${ }^{111}$ RANCIÈRE, Jacques. El espectador emancipado. Castellón, España: Ellago Ediciones, 2010.

${ }^{112}$ RANCIÈRE, Jacques. El espectador emancipado. Castellón, España: Ellago Ediciones, 2010, pág. 55.
} 
interna da obra parece um trem vermelho devido à sua enorme estrutura de ferro que sustenta as letras, atravessando toda a sala e saindo pela janela em direção aos céus.

A escolha do nome Dolores é curiosa, pois a artista conta que durante a pesquisa do projeto, ao visitar o local e a Zona Leste da cidade, ela foi absorvendo a especificidade socioeconômica e cultural do entorno da ex-fábrica. A artista encontrou cartazes colados nos postes anunciando jogos de carta e leitura de mãos, com telefones de contato e o nome Dolores escrito em vermelho. O impacto visual dessa leitura de Gross diante do contexto vivido traz todo um agenciamento de signos do lugar específico [site specific], que depois a artista leva para sua escrita plástica. Gross, ao comentar essa obra, fala que Dolores remete às mulheres do local, e sem dúvida ao nome das prostitutas, mas que também, ao mesmo tempo, traz um sentido de dor que o nome pode ter, em nome de mulher.

Durante sua pesquisa na região da antiga fábrica para o projeto de $E u S o u$ Dolores, na Zona Leste de São Paulo, a artista percebe os fluxos e o encontro de múltiplos territórios que coabitam naquele espaço da cidade, abandonado pelas instâncias públicas da cidade [sociedade], e que fora invadido por todo um novo contexto de estruturas móveis, fluidas, de territórios nômades. Estruturas móveis essas que se instalam no espaço urbano com suas feiras, ambulantes, prostitutas, moradores de rua do entorno, ou moradores ocasionais, que saem do campo para vender suas mercadorias nas "praças" da região. Portanto, esses territórios nômades se mesclam em um fluxo migratório que é regido pelas demandas econômicas dessa nova escala de metrópole contemporânea, agora fragmentada em toda a sua extensão cartográfica. Na obra Eu Sou Dolores a poética de Gross identifica certos problemas ocasionados pela mudança de eixo econômico da metrópole paulista e, em um dimensionar das representações [fixas ou fluidas], sua escrita plástica explora o vocabulário desses múltiplos territórios da metrópole mutante, que coabitam nessa região de São Paulo, demarcando e informando plasticamente [através da obra] as características tanto sociais e políticas como estéticas e semióticas.

\footnotetext{
113 “Eu Sou Dolores" fez parte do projeto Arte/Cidade Zona Leste [a fase quatro do projeto realizado anos depois das três fases iniciais, já comentadas].
} 
Sem o ritmo industrial que alimentava sua economia, e portanto sua existência, essa região da cidade foi relegada ao ostracismo que revelam as profundas mudanças, que houve e continuam havendo na metrópole paulista, trazendo novos conteúdos e novos sentidos de urbanidade. Nessa intervenção site specific, a artista trata desses questionamentos na cidade de São Paulo, instigando uma reflexão, um diálogo com o lugar onde a obra está instalada. Assim, através da fruição da obra, Gross propõe uma nova leitura do lugar, que pode ressignificar, gerar deslocamentos de sentidos e significados, ativando uma nova percepção do espaço cotidiano, urbano.

Ao analisar a situação da cidade de São Paulo, Nelson Brissac fala de uma terra de ninguém, uma paisagem terminal em que construções modernas convivem com outras formas que delatam a urgência do sobreviver, em que populações inteiras ocupam prédios vazios no centro, e terrenos na periferia da cidade, gerando uma nova economia, uma nova modalidade de território urbano. São áreas da cidade que ficam fora do sistema produtivo e do circuito da cidade. As construções permanecem como "ruínas", no processo das transformações no espaço urbano. É uma paisagem em transição, denunciando a velocidade do universo contemporâneo descartável, com seu lixo obsoleto de memória urbana, na qual os imensos galpões de antigas fábricas se tornam depósitos, ou escombros que resistem à sua destruição, para então servirem de espaços vazios, reutilizados como estacionamentos na especulação imobiliária. Um cenário de desagregação e esquecimento do passado dessas áreas, que agora são apenas restos industriais de um futuro que foi abandonado, como os monumentos de Paissac de Robert Smithson, que Brissac comenta: "São lacunas monumentais que guardam os vestígios de futuros abandonados, mapas de uma infinita desintegração. Esse lugares são não lugares, um abismo, rasgando a cidade, criando múltiplos e incompletos pontos de vista"114.

Nesse contexto, Brissac destaca na cidade de São Paulo o surgimento uma nova modalidade de território urbano, que surge de um tipo de projeto urbanístico atual que, ao não priorizar o território democrático na metrópole, provoca uma desterritorialização na totalidade da cartografia urbana contemporânea. Nessa

\footnotetext{
114 BRISSAC PEIXOTO, Nelson. Paisagens urbanas. São Paulo: Editora Senac São Paulo, 2003. [4. ed. 2009, pág. 400].
} 
cartografia urbana os tempos e as hierarquias sociais distintas convivem em tensões no justapor de seus lugares de existência, em territórios partidos por suas diferenças socioeconômicas e culturais. Nas palavras de Brissac:

A crise energética, as enchentes, e os congestionamentos apontam para uma entropia generalizada. O oposto das promessas modernistas do futuro como progresso. As formas mais extremas de modernização convivem com novas condições urbanas informais, transitórias, clandestinas - geradas pela integração global. ${ }^{115}$

A forma da metrópole contemporânea, que é agora global, traz uma característica de identidade híbrida em suas múltiplas possibilidades de fluxo. Sua memória e sua historicidade ganham uma amplitude de ações em um processo contínuo de cidade como obra humana, local e global, em um mesmo espaço-tempo. Desse modo, o processo de globalização tomou o mundo, redefinindo e reconfigurando as cidades, sua urbanização, sua extensão nas periferias, em múltiplos territórios que coabitam em um mesmo espaço urbano, com seus fluxos dinâmicos de territorialização, desterritorialização e reterritorialização. Surge uma noção de vida contemporânea que funciona como rede de fluxos, em que não se comporta mais uma noção de regionalismo crítico, de autenticidade do significado, memória e identidades como uma função diferencial. Cria-se uma nova cartografia através de um fluxo de agenciamentos de sentidos, no qual a subjetividade, a identidade e a espacialidade produzem múltiplas identidades e significados desdobrados pelas convergências imprevistas.

O processo de mundialização na constituição da sociedade contemporânea é analisado por Ana Fani Alessandri Carlos ${ }^{116}$, que utiliza a metrópole paulistana como objeto de estudo. A autora, que é pesquisadora dos estudos de urbanismo da Universidade de São Paulo, relata que atualmente existem novos parâmetros teóricos para o entendimento e análise da metrópole. Ressalta, portanto, a necessidade de se detectar o conjunto das novas contradições que decorrem desse novo momento, em

\footnotetext{
115 BRISSAC PEIXOTO, Nelson. Paisagens urbanas. São Paulo: Editora Senac São Paulo, 2003. [4. ed. 2009, pág. 393].

${ }^{116}$ CARLOS, Ana Fani Alessandri; SOUZA, Marcelo Lopes de; SPOSITO, Maria Encarnação Beltrão (Org.). A produção do espaço urbano: agentes e processos, escalas e desafios. São Paulo: Contexto, 2011 .
} 
que a hegemonia do capital industrial é superado por aquela do capital financeiro, redefinindo a partir disso os conteúdos da urbanização. Nesse sentido, as obras de Gross, ao ativar múltiplos territórios poéticos nas cidades, problematizam esses novos conteúdos e essa nova dinâmica em rede de fluxos de desterritorialização e reterriorialização. Instiga, assim, o indivíduo a vivenciar, e a praticar, essa nova cidade de São Paulo, que em seus deslocamentos econômicos se desmaterializa e se reconfigura, em fragmentos que agenciam novos sentidos estéticos e socioculturais da metrópole.

A leitura crítica de Rem Koolhaas ${ }^{117}$ sobre as cidades contemporâneas traz outra visão das mudanças estruturais ocorridas nas cidades de hoje. O arquiteto a descreve em uma megaescala [Bigness], na qual há hibridações programáticas, fricções e sobreposições que permitiriam o expandir do inesperado. Ou seja, o arquiteto apresenta uma visão de cidade como um padrão de eventos, em vez de uma composição de objetos como no urbanismo tradicional. Nas palavras de Koolhaas:

Bigness destroys, but it is also a new beginning. It can reassemble what it breaks. A paradox of Bigness is that in spite of the calculation that goes into its planning - in fact, through its very rigidities - it is the one architecture that engineers the unpredictable. Instead of enforcing coexistence, Bigness depends on regimes of freedoms, the assembly of maximum difference. ${ }^{118}$

Only Bigness can sustain a promiscuous proliferation of events in a single container. It develops strategies to organize both their independence and interdependence within a larger entity in a symbiosis that exacerbates rather than compromises specificity. ${ }^{119}$

Esses novos fenômenos urbanos, para Koolhaas, criam espacialidades heterogêneas de uso e funções variadas, em que atividades econômicas e modos de ocupação informais, aparentemente desorganizados, se constituem como um território

\footnotetext{
${ }^{117}$ KOOLHAAS, Rem; MAU, Bruce. $S, M, L, X L-$ O.M.A. New York: The Monacelli Press, 1995.

${ }^{118}$ KOOLHAAS, Rem; MAU, Bruce. $S, M, L, X L-$ O.M.A. New York: The Monacelli Press, 1995, page 511. "A megaescala [Bigness] destrói, mas também é um novo começo. Pode remontar o que se romper. O paradoxo de Bigness é que apesar de haver um cálculo em seu planejamento - na verdade, por meio de sua própria rigidez - é que essa arquitetura constrói o imprevisível. Em vez de impor essa coexistência, Bigness depende de um regime de liberdade, a montagem de diferença máxima" (tradução da autora).

${ }^{119}$ KOOLHAAS, Rem; MAU, Bruce. $S, M, L, X L-$ O.M.A. New York: The Monacelli Press, 1995, page 511. "Somente Bigness pode sustentar uma promíscua proliferação de eventos em um único recipiente. Esta desenvolve estratégias para organizar tanto sua independência como a interdependência, dentro de uma entidade mais ampla que, ao invés de comprometer com a especificidade, exacerba em uma simbiose" (tradução da autora).
} 
próprio, com sua lógica e organização. E, nesse sentido, alteram completamente a natureza do espaço urbano e suas instâncias públicas, no qual sistemas de infraestrutura são utilizados de outras maneiras. Os processos de transformação, uma verdadeira mutação das cidades que Koolhaas comenta, revelam a mudança territorial, em sua autorregulação [não planejados ou organizados], que são ativados por forças moventes inovadoras, existentes nesses processos instáveis, criando novos territórios. E a população desses novos territórios experimenta o capitalismo global, em sua dimensão de absoluta mobilidade, no fluxo da reciclagem, da distribuição informal, dos artefatos, veículos, barracas de venda, e todo um design e arquitetura desenvolvidos para esse deslocamento fácil. No mesmo processo se encontram as moradias, com assentamentos simples adaptáveis aos contornos da cidade, nos mais diversos materiais e técnicas de um instrumental de sobrevivência, e que segundo Antonio Negri ${ }^{120}$ gera uma nova economia e uma nova condição de ocupação territorial. Um território que fala da luta pela sobrevivência de uma política do deslocamento, em que se criam novos instrumentos e condições urbanas para se lidar com o processo exclusivo a que essas populações foram submetidas. Trechos da análise de Brissac $^{121}$ :

[...] através de seus deslocamentos, eles constituem territórios moventes e dinâmicos que se espalham, como uma mancha fluida, pelas antigas áreas industriais, pelas margens das grandes vias de transportes, nos terrenos vagos deixados pela especulação imobiliária.

[...] suas ações são operações de travessia, de transgressão de fronteiras - geopolíticas e sociais, privadas e públicas. Buscam criar zonas que sejam territórios abertos nos intervalos dos espaços estruturados da cidade.

Para Brissac, essas populações deslocam os limites físicos tradicionais dos excluídos das cidades nas periferias para ocupar toda a cidade, infiltrando-se nas fissuras, nos vazios da cartografia urbana. E que faz parte de uma manobra de reconquista do terreno urbano, da recuperação de um território [reterritorialização], que foi desterritorializado pelas regulamentações administrativas da urbanização excludente do capitalismo. Segundo o autor, "Eles criam uma configuração movente,

\footnotetext{
${ }^{120}$ NEGRI, Antonio; HARDT, Michael. Império. 8. ed. Rio de Janeiro: Record, 2006.
} 
radicalmente desprovida de forma estrutural. Uma arquitetura e um urbanismo liquefeitos que só podem ser percebidos através de seu fluxo" ${ }^{\text {"122 }}$. O informal, ao criar zonas abertas e fluidas nos espaços vazios da cidade estruturada, para Brissac, dissolve a arquitetura e o urbanismo existentes, criando novos territórios flexíveis e dinâmicos de uma urbanização informal. E nesses novos usos, como as margens das avenidas, os espaços dos viadutos, passarelas, entre outros espaços da cidade, são reutilizados, ocupados, para o uso informal da população, com seu comércio, serviços e moradias, criando assim, em um radical experimento urbano e social, um novo território, em um novo modo de reestruturação urbana, que tem como característica um desmantelamento da infraestrutura de cidade, que por estar em colapso é utilizada para outros fins.

A globalização, segundo Koolhaas, apesar de gerar cidades produtivas, nelas existe uma total ausência de infraestrutura. E, nesse sentido, as deficiências acabam criando alternativas criativas e eficazes para garantir o sistema informal [e ilegal] funcionando. Ou seja, a globalização, com seu urbanismo material, descentralizado e congestionado, promove muitas oportunidades para se operar fora dos sistemas regulatórios. E, para Brissac, a urbanização informal segue uma lógica diferente. Diz que poderia haver, a partir dessas novas condições de cidade, um novo urbanismo, que voltado para a irrigação de territórios em potencial poderia criar campos, nos quais acomodasse processos fluidos que se recusam a ser cristalizados em formas definitivas.

Sendo assim, o autor ressalta a necessidade de se criar uma nova cartografia das dinâmicas, dos fluxos e das reconfigurações permanentes, e variáveis. E que, para isso, é preciso criar dispositivos abstratos de análise que levem em consideração a complexidade, e a indeterminação desses fluxos de reconfigurações. E nesse sentido as obras de Gross poderiam contribuir como uma leitura poética das cidades, não no intuito de analisar a complexidade desse campo, mas de explorar esteticamente elementos dialógicos dessa nova cartografia, cujo conjunto operatório de linhas e

\footnotetext{
121 BRISSAC PEIXOTO, Nelson. Paisagens urbanas. São Paulo: Editora Senac São Paulo, 2003. [4. ed. 2009, pág. 425].

122 BRISSAC PEIXOTO, Nelson. Paisagens urbanas. São Paulo: Editora Senac São Paulo, 2003. [4. ed. 2009, pág. 428].
} 
zonas, de traços e manchas, não é representativo. Para assim, ao estabelecer novas conexões, potencializar novos acontecimentos e configurações na leitura da cidade. Brissac acredita que, através desses dispositivos abstratos, pode-se apreender essa nova dimensão informal das sociedades que se constituem em uma rede frouxa de alianças transversais, tecendo sistemas instáveis em perpétuo desequilíbrio. Uma exposição das relações de forças próprias que configuram o poder de afetar e ser afetado, em uma noção de campo em vez de forma. Ao contrário da estrutura, que funciona com um conjunto de posições, o campo é feito de vetores que procedem por variação, expansão e conquista como em um sistema rizomático. É uma questão de composição e agenciamentos de forças complexas, em vez de organização hierárquica, linear de espaço, que se comporta mais por acontecimentos do que por formas. Um espaço amorfo, informal, que para ser analisado é necessária uma abordagem voltada para o processo. Um mapeamento da informalidade, de suas "linhas de fuga", da dinâmica dos agenciamentos e das intensidades dos múltiplos territórios que coabitam nas grandes e complexas extensões territoriais das metrópoles contemporâneas.

Esse processo de múltiplos territórios que coabitam em metrópoles como São Paulo é abordado pelas obras de Gross nas cidades. Nesse contexto, seus trabalhos atuam como práticas poéticas que dialogam com essa noção de campo, unindo ética e estética ao trazer questões sociais, que podem instigar tanto o habitante como o passante daquelas regiões a novas reflexões, apreensões e discussões profundas a respeito do passado, presente e futuro da cidade, como uma apropriação simbólica que fala de uma arqueologia do tempo presente. E, desse modo, problematizar e fomentar discussões no diálogo com a cidade, gerando deslocamentos plásticosimbólicos que agenciam sentidos provisórios de existência, diante da nova cartografia poética na qual as obras estão instaladas.

As obras de Gross nas cidades se diferenciam completamente de certos "monumentos" que hoje em dia são alocados totalmente desconectados de um diálogo com a cidade. O olhar crítico de Mywon Kown analisa esses discursos desconectados e adverte nesse sentido, para processos artísticos que são transformados em objetos inertes, nos quais a arte site specific vem "representar" a 
criticidade mais do que realmente exercê-la. Ou seja, para a autora ocorre muitas vezes uma domesticação dos trabalhos de vanguarda pela cultura dominante. Portanto os artistas, que apesar de estarem convencidos de um sentimento anti-institucional e crítico à ideologia dominante, são também os protagonistas dessa conversão, devido ao forte desejo de legitimação cultural.

No âmbito da urbanização e arquitetura, a busca por uma legitimação cultural, econômica, das instâncias políticas da cidade surgiu nos anos 1990 com o "planejamento estratégico" e, segundo Adrián Gorelik ${ }^{123}$, trata-se de um modelo urbano que propõe assumir os limites da gestão pública e aceitar a dimensão mercantil do território metropolitano, incorporando francamente os capitais privados à reforma urbana, concebida de modo fragmentário, como peças urbanoarquitetônicas que enfatizam a capacidade da forma arquitetônica, tanto no plano das necessidades identitárias da cidadania como no valor dos commodities dos edifícios e locais urbanos. Tudo isso temperado pela arquitetura de "marca". A centralidade da cultura na economia urbana da "cidade arquipélago"124 acabou engendrando nas cidades uma generalização [que se esvaziou totalmente de significados] na busca de uma originalidade arquitetônica, como uma espetacularização do urbano ${ }^{125}$, com suas estratégias de monumentalização em formas cristalizadas da celebração do urbano, da mercantilização da arte e da cidade. Essa espetacularização da arquitetura somente introduz nas cidades obras de arte e arquitetura, que tendem ao marketing e ao espetáculo, rechaçando o diálogo e a experiência da cidade, onde chegam como informação, mercantilização e alienação. Realizam transformações que, sem uma relação produtiva entre as obras, e a gestão do espaço urbano, só podem contribuir

\footnotetext{
${ }^{123}$ GORELIK, Adrián. O romance do espaço público. Arte \& Ensaios, Rio de Janeiro (EBA-UFRJ), n. 17, págs. 189-205, 2008.

${ }^{124}$ A fragmentação urbana do "planejamento estratégico" contou, segundo Gorelik, com o auxílio de uma "harmônica dupla estratégica", os urbanistas e os empresários encontraram nas cidades um novo campo de acumulação. Os urbanistas se dedicam, aparentemente por modismo, a projetar [provocativamente] em explícitos termos gerenciais; e os empresários não fazem mais do que celebrar os valores culturais da cidade, enaltecendo o "pulsar" de cada rua, praça ou fragmento urbano - jargão de autenticidade urbana, que o autor chama de culturalismo de mercado.

${ }^{125}$ Essa espetacularização do urbano remete a tempos da exuberância arquitetônica dos museus de Frank Gehry ou de pontes de Santiago Calatrava. Momento da arquitetura e urbanismo que leva Gorelik a citar Rem Koolhaas, em seu ácido [irônico] discurso: "a cada riacho sua calatrava". GORELIK, Adrián. Políticas de la representación urbana: el momento situacionista. Revista Punto de Vista, Buenos Aires, n. 86, 2006.
} 
para mais fragmentação, e estagnação, de um conceito democrático e participativo de cidade.

De fato, ao não se estabelecer uma comunicação com o lugar, com os que vivem e se relacionam naquele contexto territorial, fica quase impossível traçar um mapa simbólico da cidade que visualize, através da imagem e identidade do lugar, as narrativas da cidade. Gross e seus territórios poéticos contribuem para esse traçar vivencial, dessa cartografia simbólica de São Paulo [e das outras cidades com que dialoga]. Sua escrita plástica, a partir de signos plásticos e semânticos, poeticamente amplia e flexibiliza o significado e o entendimento sobre arte, encantamento, política, cor, superfícies, memória, tempo, ética, suspensão e desvio, no corpo da cidade [mutante] híbrida e transitória. Assim, propõe novas cartografias [poéticas], que em um sentido amplo do signo do deslocamento remetem ao contexto de limites fronteiriços que se expandem em fluxos migratórios e êxodos poéticos. E, através de uma experiência estética [fenomenológica], signos da memória e de afetos se expandem e se deslocam na geografia socioeconômica, cultural e política de uma cidade.

Na cidade híbrida e transitória, Gross circula sua obra Carne [Figura 55], que trata de um interessante diálogo de deslocamento, do vivenciar os fluxos poéticos da cidade, tanto em nível físico, material, como simbólico, com a arte, com a educação formal [escola] e informal da cidade de São Paulo. Essa obra faz parte do projeto Arte Passageira, elaborado pelo setor educativo do Centro Universitário Maria Antonia, no qual um ônibus utilizado como suporte artístico de uma ação seria "exibido" em circulação durante um ano letivo em escolas e instituições culturais da cidade. Esses parâmetros do projeto já estavam estabelecidos quando Gross foi convidada a participar. Contudo, Carne nasceu de um trabalho coletivo da artista com o grupo de estagiários que trabalhara tanto no processo de produção da obra como no desenvolvimento do projeto educativo. O projeto Arte Passageira tinha como objetivo artístico pedagógico a apropriação de um velho ônibus escolar desativado da USP. E Gross, a partir desse ônibus, cria uma intervenção na cidade que se desdobra em uma ação educativa de deslocamento. Ou seja, circula com Carne, sua obra-ônibus, pela cidade, indo às escolas para buscar as turmas de crianças para visitar o 
Centro Universitário Maria Antonia. A palavra "carne" escrita na frente do ônibus evoca um sentido quase irônico dessa travessia de crianças como corpos, [carnes] sendo deslocados pela cidade. Carne estampada em luzes vermelhas na parte frontal do veículo parece não indicar o destino do ônibus, mas alertar para o conteúdo, ou mercadoria que está sendo transportada. Carmela Gross comenta essa obra:

Não se trata de uma obra efêmera, mas de uma obra-na-circulação, com os desdobramentos que isso implica - transitividade, impermanência, transformações espaciais e temporais... Os acontecimentos reais da vida da cidade são componentes dinâmicos da obra, ou melhor, obra e fluxo se pertencem e se misturam. ${ }^{126}$

A proposta da artista, ao recobrir [encapar] o ônibus de vermelho utilizando plásticos adesivos [com os que se encapam cadernos escolares], em uma composição de recortes em patchwork, se apropria de práticas escolares para transformar um objeto do cotidiano [ônibus escolar] em objeto artístico. Gross desloca a vivência cotidiana banal do transporte escolar em uma experiência intensa da cor, alterando visualmente a percepção. Provoca os sentidos, em um fascinante desdobramento didático do objeto de arte, um experimento óptico. Isto é, cria [dentro do ônibus] um espaço-cor em que é possível entrar, mergulhar, em uma única cor [vermelho], e o passageiro-aluno, impregnado pelo efeito óptico, é contaminado por sua cor complementar [verde], que se revela naturalmente, ativando nele uma compreensão do universo das cores e suas complementares, que poucas aulas de arte poderiam promover. A obra Carne, através de seu deslocamento físico, e simbólico, promove um diálogo entre a educação formal, informal, e a cidade. Nas palavras de Gross:

A obra de arte se desdobra em trocas múltiplas com o outro, que podem também ser compreendidas como educação, aprendizado, conhecimento, difusão, circulação, interação... Como projeto institucional, a proposta arte-ônibus-educação funciona como uma espécie de química reveladora do processo artístico. ${ }^{127}$

Em seguida, a fala de Lorenzo Mammì sobre essa mesma obra:

\footnotetext{
${ }^{126}$ Entrevista com Carmela Gross, por Rosa Iavelber. Catálogo da exposição Carmela Gross. CARNE. Org. João Bandeira. São Paulo: Centro Universitário Maria Antonia, 2006.
} 
[...] um ônibus que impõe a seus passageiros uma percepção alterada do mundo e de sua própria condição humana, talvez seja a metáfora perfeita da obra de arte: um objeto construído como os outros, aparentemente igual, ou quase, aos outros. Mas que, em algum momento, por alguma razão, encarnou um significado. Tornou-se um corpo. ${ }^{128}$

Os territórios poéticos ativados por Gross são deslocamentos físico-simbólicos construídos entre múltiplas dimensões [artística, sociocultural, urbana, ética e política] que coabitam no espaço das cidades. A artista, ao longo de seu percurso artístico na cartografia das cidades, utiliza diferentes linguagens [técnicas e suportes] no dialogar com o contexto urbano e a arquitetura. E na França a artista realiza um interessante diálogo com a arquitetura e o contexto urbano, cultural, do local escolhido pela prefeitura de Paris, em um projeto de parceria entre a prefeitura de São Paulo e a de Paris. Essa parceria consistira em convidar um artista parisiense para fazer uma intervenção permanente em algum espaço arquitetônico na cidade de São Paulo, do mesmo modo que um artista paulistano faria sua intervenção na cidade de Paris. Sendo assim, Carmela Gross, convidada pela então prefeita da cidade de São Paulo Marta Suplicy para participar desse projeto, projeta e realiza sua intervenção permanente no espaço do jardim e no prédio da Escola René Binet, situada no limite do $18^{\circ}$ bairro de Paris com St. Denis, um bairro afastado do centro de Paris, onde a maioria da população é de imigrantes árabes e africanos. O diálogo que seu jogo poético ativa no espaço da escola e do bairro convida a uma profunda reflexão sobre questões socioeconômicas e culturais contemporâneas.

É oferecida a Gross a fachada da escola, na qual a artista trabalha nas três frestas, e ocupa também o caminho de acesso à escola, que corta um grande jardim. Os interstícios dos três andares do prédio, entre as fileiras de janelas, ela recobre de placas geométricas com as cores primárias [e uma variação de vermelho] que dão nome à sua obra: bleu, jaune, rouge, rouge ["azul, amarelo, vermelho, vermelho"] [Figuras 56, 57 e 58]. Carmela Gross comenta que essa intervenção da fachada seria como um "vitral pelo avesso", visto a partir de fora. O pensamento do desenho da poética de Gross mais uma vez pode ser percebido aqui nessa obra, ao relacionar as

\footnotetext{
${ }^{127}$ Entrevista com Carmela Gross, por Rosa Iavelber. Catálogo da exposição Carmela Gross. CARNE. Org. João Bandeira. São Paulo: Centro Universitário Maria Antonia, 2006.

128 MAMMİ, Lorenzo. "Desenhar, encarnar e organizar". Catálogo da exposição Carmela Gross. CARNE. Org. João Bandeira. São Paulo: Centro Universitário Maria Antonia, 2006.
} 
linhas da arquitetura em sua verticalidade com a horizontalidade do chão, compondo em uma mesma cadência cromática as formas da fachada, que são repetidas no caminho que contorna a entrada da escola. Contudo, as formas geométricas são diferentes, de modo que se encaixam acrescentando o espaço vazio [cinza] do cimento original, que, assim aproveitado, ajuda a compor o desenho geométrico. Desse modo, Gross joga com a verticalidade [no plano da fachada da frente do edifício] compondo com as aberturas envidraçadas um ritmo de percepção espacial, que se expande e continua em movimento na horizontalidade do chão. As placas coloridas e o caminho têm o mesmo ritmo, e, de acordo com Carmela Gross, "o mesmo molejo do samba de breque. É o lugar da ação, enquanto o muro é o da contemplação", diz ela ${ }^{129}$.

Nessa intervenção site specific a artista, mais uma vez, amplia o universo plástico se utilizando do suporte artístico para alargar conceitos. Através de uma sutileza poética muito interessante, Gross estabelece um jogo cromático com a metáfora dos simbolismos das cores da bandeira francesa. As cores da identidade francesa, azul, branco e vermelho, são trocadas pelas cores primárias, "cores puras" [azul, amarelo e vermelho] que, ao remeter ao universo infantil das práticas artísticas, e das escolas, parece dialogar metaforicamente com as "cores puras" da nação, da identidade [bandeira] francesa. Assim apresentados no cotidiano de uma escola, o lugar do "se tornar franceses", esses jogos visuais atuam como potência de reflexões expandidas das arqueologias simbólico-culturais de sua identidade como nação, em transformação. O branco se tornou amarelo, e a única cor que se repete da tríade primária, "pura", dessa identidade, o vermelho, surge transformado, misturado às outras cores, denunciando sutilmente o novo contexto socioeconômico e cultural, racial [principalmente nas periferia e nos bairros pobres] dos centros urbanos da França de hoje. Sheila Leirner, em sua crítica para o jornal O Estado de São Paulo, comenta essa obra:

${ }^{129}$ LEIRNER, Sheila. Carmela Gross pinta fachada em Paris. O Estado de São Paulo, São Paulo, Caderno 2, 26 de maio de 2004. 
Carmela continua a tecer e decifrar os enigmas das conexões entre os pensamentos e a ação artística. Como sempre fez, questiona a validade do gesto e disciplina as relações entre o artista e os seus instrumentos de criação.

[...] a artista continua a produzir um ensaio que descreve e defende a operação de um pensamento por meio de uma demonstração. ${ }^{130}$

Em um diálogo mais recente com a cidade de São Paulo, Carmela Gross cria outra obra de intervenção site specific, Iluminuras [Figuras 59 e 60], feita para a exposição Carmela Gross, um corpo de ideias, realizada na Estação Pinacoteca em 2010. A artista, nessa intervenção, realiza uma instalação de dezenas de luzes [giroflex] de emergência, amarelas, girando sem parar em vários pontos da fachada do prédio, que era o prédio do DOPS-SP durante a ditadura militar, "iluminando", denunciando, uma narrativa sociocultural e histórica na paisagem suja do centro da cidade de São Paulo.

O prédio e suas luzes [que remetem aos carros de polícia em deslocamento] falam de uma urgência, mas, sem o som que geralmente acompanha o "caso de emergência", gera um estranhamento. Há um deslocamento simbólico, em que o silêncio do alerta emergencial se revela na luz, em movimento constante, destacando a arquitetura de um prédio impregnado de histórias, silenciadas pela repressão [abusiva] da ditadura militar. A ditadura e seu maior órgão de repressão, o DOPS ali se instalou e utilizou esse mesmo espaço arquitetônico para intermináveis torturas [e até morte] de presos políticos. De modo que, no tempo silenciado, escondido, dessa época, surgem luzes de emergência, rodando, rodando, rodando sem parar, até se tornarem outra coisa, outro tempo, outros múltiplos territórios poéticos. Assim, apesar desse diálogo com o passado recente da cidade, a luz que fica girando silenciosamente em diversos pontos da arquitetura do prédio traz outra configuração plástica, estética, desvelando o desenho da antiga estação de trens, edificada no início do século XX, uma época de esperança no novo, na máquina que iria trazer a tecnologia para uma vida mais fácil, a era da ocupação e da industrialização da cidade. Desse modo, outra vez alude ao deslocamento, em uma narrativa histórica que agora desloca signos de um potente discurso plástico, que evocam a memória da

\footnotetext{
${ }^{130}$ LEIRNER, Sheila. Carmela Gross pinta fachada em Paris. O Estado de São Paulo, São Paulo, Caderno 2, 26 de maio de 2004.
} 
cidade. A escrita plástica de Gross em Iluminuras conta sua história visualmente, como nas iluminuras medievais que, apesar do conteúdo institucionalizado pela Igreja dominante, através de seus desenhos, seus traços singulares, denunciavam as culturas escravizadas e silenciadas pelo autoritarismo da Igreja católica. E Gross, então, na sua Iluminuras, quebra um silêncio da cidade, erguendo aos céus da metrópole sua memória, seus trágicos silêncios, seu esplendor, em um diálogo que transgride o espaço e o tempo na obra.

Os diálogos que Gross estabelece com as cidades ampliam também críticas sociais e políticas no campo da arte. Suas palavras, "desenhadas" em letreiros luminosos, exploram com a "luz" e os "signos" da cidade seus diálogos sutis, poéticos [recheados de potência crítica], em prédios institucionais, como na obra Hotel [Figura 61]. Essa obra, feita para a XXV Bienal Internacional de Artes Plásticas de São Paulo, em 2002, é constituída de cinco letras de grandes dimensões [realizadas com lâmpadas fluorescentes], e instalada na marquise da entrada do prédio da Bienal, formando a palavra "Hotel". Assim, durante todo o período da XXV Bienal, a instalação envolve plasticamente o público que entra no prédio, e os que, à distância, avistam o prédio de outros pontos da cidade. Esse trabalho de Gross provoca o pensar, problematizar a função simbólica de uma bienal, diante da imensa quantidade de obras de diversos países, “alojadas" por alguns meses naquele prédio da cidade de São Paulo. Hotel propõe, a partir de desdobramentos simbólicos ativados por apenas uma palavra, gerar uma reflexão crítica institucional ao deslocar signos e sentidos. Outra obra da artista que problematiza o lugar da arte na sociedade é Se Vende [Figura 62], uma instalação com letras fluorescentes alocadas no pátio de entrada da mostra paralela no Centro Cultural Matadero, durante a feira de arte ARCO de Madrid, em 2008. Poucos anos depois, foi instalada no pátio do estacionamento da Estação Pinacoteca, em 2010.

Nesse deslocamento das mesmas palavras de um local ao outro, criam-se novas relações de sentido plástico e simbólico com a frase "Se Vende". No caso da instalação Se Vende no Centro Cultural Matadouro em Madrid [durante o período da Feira de Arte Contemporânea ARCO], a "mercadoria à venda" era outra, ou seja, a metáfora [entre outros desdobramentos desse discurso crítico-semântico] remetia a 
frase à questão da mercantilização da arte. A instalação de um letreiro luminoso, na entrada do centro cultural, atuava como um dispositivo poético direcionando seu sentido comercial às obras expostas como artigos à venda, envolvendo o espectador em problemáticas éticas, que discutem o lugar e a função da arte como objeto comerciável. Contudo, na interferência [direta] com a cidade de São Paulo, no espaço do estacionamento da Estação Pinacoteca, o diálogo que se estabelecia era com o centro da metrópole [Figura 63]. O letreiro destacava um cenário urbano sujo e desordenado, conectado por traçados das linhas de trens em primeiro plano e os arranha-céus ao fundo. Estabelecia desse modo outra relação poética com a frase, na qual outra problemática, totalmente diferente, estava instalada. Sendo assim, cada instalação das palavras "Se Vende", a partir dos elementos simbólicos do contexto onde a obra está inserida, gera agenciamentos poéticos que exploram novas percepções, sentimentos, sentidos e problemáticas diversas diante da mesma obra. Desse modo, a partir de um mesmo "objeto plástico" [as letras luminosas], com a mesma tipologia, e organizadas do mesmo jeito, ativam a cada contexto físico e simbólico diferentes deslocamentos plásticos e conceituais, diante da nova cartografia poética que surge onde as obras estão instaladas.

Nesta, e em outras obras, as palavras de Gross, com seus sentidos ampliados, metafóricos, que se encontram e se expandem na obra, em diálogo constante com o local onde está instalada, deflagram no espectador um instrumento crítico de observação que alude a um tipo de comunicação visual encontrada em letreiros comerciais. Esses letreiros luminosos evocam uma necessidade de comunicação veloz, com o máximo de significado possível. Eles anunciam produtos desde mercadorias a espaços turísticos [hotéis, restaurantes] ou de entretenimentos [teatros, cinema] em metrópoles como Nova York e Las Vegas, onde a perspicácia literária, além de artística, é um destaque a ser feito a essa linguagem, que usa diversos meios, como palavras, imagens e esculturas, para persuadir e informar. Essa linguagem dos letreiros luminosos que Gross utiliza em algumas de suas obras, nas quais o conteúdo é rápida e facilmente assimilado, também nos remete ao universo da Arte Pop, que explora a técnica artística da linguagem dos quadrinhos, e do design das mercadorias, para fazer sua crítica ao mundo [consumista] capitalista. E desdobrando esse contexto 
da Arte Pop na sua poética, a artista na obra Se Vende se apropria da tipologia das letras utilizadas no famoso letreiro [de grande escala] "Hollywood", alocado nas montanhas de Beverly Hills, em Los Angeles. Gross, diante dessa escolha, explora a tipologia desses letreiros luminosos trazendo signos culturais urbanos norte-americanos. É interessante destacar a análise da linguagem desses letreiros luminosos, que um grupo de arquitetos faz no livro Aprendendo com Las Vegas, no qual exploram a arquitetura e o urbanismo da cidade de Las Vegas:

Compreender o conteúdo das mensagens pop e o modo como ele é projetado não significa que seja preciso concordar com esse conteúdo, aprová-lo ou reproduzi-lo. Se as persuasões comerciais que piscam na Strip são uma manipulação materialista e uma comunicação insípida, que apela astuciosamente a nossos impulsos mais profundos, mas manda somente mensagens superficiais, isso não implica que nós arquitetos, que aprendemos com suas técnicas, devamos reproduzir o conteúdo ou a superficialidade de suas mensagens. ${ }^{131}$

De fato, essa linguagem de letreiros luminosos remete à superficialidade de uma comunicação que se pretende instantânea, visando à manipulação materialista no campo visual das cidades. Em Se Vende, mais uma vez, a artista, em sua escrita plástica, utiliza o mesmo instrumental [técnico] simbólico, o qual problematiza, para construir sua obra. Sua poética na cidade de São Paulo, em obras como Se Vende, Hotel, Eu Sou Dolores e Iluminuras, também se utiliza de um instrumental simbólico que remete à visualidade do universo tecnológico contemporâneo. E através do qual constrói sua poesia plástica sensorial, que deflagra uma potência crítica [política] em obras que instalam problemáticas contemporâneas, como as questões socioculturais e políticas da metrópole paulista, ou o sistema da arte, e as relações entre arte e sociedade.

A experimentação das práticas artísticas nas cidades contemporâneas brasileiras, segundo Lilian Amaral ${ }^{132}$, tem investigado nos últimos anos o imaginário urbano através de processos colaborativos. Em uma concepção ampliada da arte como experiência, essas práticas artísticas se utilizam dos lugares [reais e imaginários] como suporte para suas criações coletivas de diferentes linguagens,

\footnotetext{
131 VENTURI, Robert; SCOTT BROWN, Denise; IZENOUR, Steven. Aprendendo com Las Vegas. São Paulo: Cosac Naify, 2003, pág. 201.
} 
meios e contextos. Há hoje, de acordo com a análise de Mywon Kwon, nas práticas site oriented [que abordam o site como narrativa discursiva], o interesse institucional, demandando um intenso trânsito de artistas a várias cidades, ao longo do mundo, da arte cosmopolita. Artistas itinerantes, que se transformam em viajantes, hóspedes, aventureiros, críticos temporários e pseudo etnógrafos. ${ }^{133}$ As localidades, sem dúvida, contribuem para uma identidade específica, ao injetar a singularidade do lugar na experiência. E a arte site specific pode levar a emergência de histórias reprimidas, prover apoio a maior visibilidade para grupos e assuntos marginalizados, e também instigar à redescoberta de lugares ignorados até então pela cultura dominante. No entanto, Kwon ressalta que, considerando a ordem socioeconômica atual que cresce na produção artificial, e no consumo de massa, a exposição de arte em lugares "reais" pode também significar uma maneira de extrair as dimensões históricas e sociais dos lugares, para servir apenas de forma diversificada ao impulso temático do artista, ou mesmo somente para satisfazer perfis demográficos, institucionais, ou só para preencher necessidades físicas da cidade $^{134}$. E desse modo, para Kwon, a arte site specific pode também ser mobilizada para acelerar o apagamento das diferenças, via comercialização e serialização de lugares. Isso devido ao fato de que a indiferenciação espacial e a desparticularização exacerbam os efeitos de alienação e fragmentação da vida contemporânea, com sua homogeneização dos lugares e o [consequente] apagamento das diferenças estéticas, simbólicas e culturais.

A poética de Gross nas cidades ativa um experimentar de fluxos poéticos nessa megaescala [Bigness] de cidade [e contexto de vida da contemporaneidade] através de novos agenciamentos entre signos e sentidos, em um nomadismo rizomático que problematiza, ressignifica conceitos e percepções. Os deslocamentos de sentidos que suas obras promovem nessa cidade híbrida constroem um diálogo singular, pois a

132 BARBOSA, Ana Mae; AMARAL, Lilian (Org.). Interterritorialidade: mídias, contextos e educação. São Paulo: Editora Senac São Paulo; Edições SESC SP, 2008, pág. 47.

${ }^{133}$ Segundo Mywon Kwon, o artista que antes era um fazedor agora é um facilitador, educador, burocrata. As decisões, os movimentos e a elaboração crítica se desdobram em volta do artista. E essa orquestração dos sites discursivos e literais cria uma narrativa nômade que requer o artista como narrador-protagonista.

${ }^{134}$ Mywon Kwon diz que, significativamente, a apropriação da arte site specific para a valorização das identidades urbanas vem em uma época de mudança cultural importante, em que a arquitetura e o urbanismo, que antes eram os principais meios de expressar a visão da cidade, são deslocados por outros meios, como o marketing e a publicidade. 
relação que se estabelece com cada site specific não se esgota nessa esfera crítica discursiva. Gross, em seu diálogo com as cidades, problematiza muitas questões da metrópole contemporânea, em obras que muitas vezes atuam como uma narrativa discursiva. Entretanto, parece que a artista não pretende nessa "leitura crítica do site" extrair as dimensões históricas e sociais dos lugares, mas propor [nos espaços urbanos e nas instituições de arte] experiências estéticas, que instigam o espectador, em sua experiência cotidiana, a mergulhar na transitoriedade da experiência artística. São experiências fenomenológicas que se desdobram em múltiplos sentidos plásticos, simbólicos e conceituais. Assim, na pluralidade de sua poética, ativa experiências estéticas como Hotel e Se Vende, que, instaladas em prédios de instituições de arte, discutem situações de crítica institucional e remetem ao questionamento das relações do sistema da arte. Em outras, como Eu Sou Dolores, são problematizadas questões socioeconômicas e culturais de uma cartografia urbana [da metrópole paulista] que abandona e redefine geopolíticas, em hierarquias arbitrárias de ocupação da cidade. Há também situações de um conviver da obra na cidade, em que integra sua poética nos espaços urbanos de Laguna e Porto Alegre com as obras Fonte/Foz e Cascata, nas quais sutilmente promove a experiência de um espaço público revitalizado. Nestas, a artista trata plasticamente o espaço urbano de modo que a sociedade os aproprie, e os integre, no seu uso cotidiano urbano, como vestígios poéticos de um novo lugar para se experimentar e viver a cidade. Através dessa diversidade poética Gross ativa territórios móveis, em constante definição subjetiva de um lugar poético, onde a multiplicidade simbólica de seus territórios atua no espaço urbano e nos museus como jogos sensoriais, éticos, estéticos e críticos a serem experimentados. Assim, possibilitam o despertar de reflexões e interações criativas em cada indivíduo que se disponibilize ao devir poético de Gross.

É óbvio que são inúmeras e variadas as leituras, interpretações e apropriações de tais territórios poéticos [lugares reais ou simbólicos] criados por Gross. Eles são impossíveis de qualificar ou quantificar, o que também é desnecessário abordar na atual pesquisa. Entretanto, o interessante a destacar é que, independentemente da leitura individual ou coletiva que a obra promova, esta funciona como um dispositivo artístico de comunicação que provoca encontros, reflexões, agenciamentos de novas 
narrativas, novos sentidos e deslocamentos poéticos, que geram uma infinidade de novas leituras de mundo. A poética de Gross engendra uma nova geografia de afetos na cartografia das cidades, ampliando sentidos, discursos e ressignificações de um patrimônio urbano [material e imaterial] no fluxo da cidade contemporânea. E, para concluir, a visão poética do escritor Italo Calvino:

[...] O Olhar percorre as ruas como se fossem páginas escritas: a cidade diz tudo o que você deve pensar, faz você repetir o discurso, e, enquanto você acredita estar visitando Tamara, não faz nada além de registrar os nomes com os quais ela define a si própria e todas as suas partes.

Como é realmente a cidade sob esse carregado invólucro de símbolos, o que contém e o que esconde, ao se sair de Tamara é impossível saber. ${ }^{135}$

${ }^{135}$ CALVINO, Italo. As cidades invisíveis. São Paulo: Companhia das Letras, 1990, pág. 18. 


\section{4}

\section{Capítulo III. As Escadas ${ }^{136}$ de Gross}

Carmela Gross utiliza materiais como madeira, alumínio, fios e lâmpadas para dar corpo a diversas escadas de tamanhos e formatos diferentes no vão do átrio da torre de um dos prédios do SESC Belenzinho, em São Paulo. A obra de Gross Escadas inaugura, em abril de 2012, o projeto Vão do SESC Belenzinho, que tem como objetivo convidar artistas para investigar a pluralidade do ambiente, e propor uma intervenção no vão do átrio da torre. Suas escadas, umas de madeira, outras de alumínio, cobertas com luzes de neon brancas, saem do chão de vidro que cobre a piscina em direção ao quarto andar do prédio, criando inúmeras conexões. Estas criam inúmeras linhas no espaço e, dependendo do ponto de vista do observador, provocam uma infinidade de possibilidades perceptivas. São Escadas que refletem, se desdobram em linhas de luzes de neon, formando diferentes imagens durante o deslocamento do observador. E diante de uma repetição contínua para baixo e para o lado, essas linhas luminosas constroem uma conversa de formas no chão, na parede, e para além delas. Nesse sentido, na instalação de Gross as escadas funcionam como elementos gráficos, signos geométricos, linhas, quadrados, retângulos, que indicam caminhos e aproximam partes da arquitetura antes desconectadas. Claire Bishop parece comentar essas questões que surgem na obra de Gross, quando em seu livro conceitua a instalação como meio artístico. Com suas palavras:

[...] in a work of installation art, the space, and the ensemble of elements within it, are regarded in their entirety as a singular entity. Installation art creates a situation into which the viewer physically enters, and insists that you regard this as a singular totality. ${ }^{137}$

\footnotetext{
${ }^{136}$ Escadas, instalação de Carmela Gross no projeto Vão, SESC Belenzinho, São Paulo, abril a junho de 2012.

${ }^{137}$ BISHOP, Claire. Installation Art: A Critical History. London: Tate Publishing, 2010. “[...] em uma obra de arte como a instalação, o espaço e o conjunto de elementos dentro dele são considerados em
} 
$\mathrm{Na}$ instalação de Gross os reflexos das linhas/luzes expandem percepções [e conceitos] na água, no vidro e na rotina de um lugar poético a ser experimentado no espaço de convivência do SESC Belenzinho. E como um jogo que se dá entre os reflexos e os objetos do espaço, a obra de Gross se desdobra poeticamente em um universo de múltiplas possibilidades de direções e sentidos. Diante da diversidade de pontos de vista, a metáfora de uma conexão que o objeto escada sugere não se encerra em si mesmo. Há um transbordamento do objeto [de arte], que aqui, no caso uma escada, une fragmentos, lugares, antes distantes no espaço. Como se a partir desse objeto artístico, ou seja, dessas escadas instalados por Gross, fosse possível acessar a totalidade do espaço do átrio da torre do SESC Belenzinho.

Nessa obra a artista, depois de dez anos, volta a dialogar com o espaço do SESC, expandindo conceitos e percepções. Contudo, não mais em palavras com suas luzes vermelhas de neon, como na obra Eu Sou Dolores, mas através de desenhos com luzes brancas que ressignificam o espaço, criando provisoriamente novos lugares de existência, de convivência compartilhada. Um caminhar que a cada passo se desdobra na possibilidade de uma nova obra, um novo lugar a ser experimentado. Carmela Gross é uma artista que ao longo de seu percurso plástico e poético experimenta e explora questões que se voltam para a imagem, o ambiente, o espaço urbano e o próprio sistema da arte. Suas obras não são como objetos de arte que pedem contemplação e em que se realiza uma fruição que tem um fim em si mesma. Os objetos-escadas que a artista instala no espaço do SESC funcionam como um acesso, no qual a obra é o início de um processo de experiências que expandem sentidos e limites conceituais. Desse modo, a partir dela, são ativados nos ambientes outras relações com diferentes campos de conhecimento, como as relações sociais, arquitetônicas e históricas com o local [site specific].

No prédio do SESC Belenzinho, em 2002, nas ruínas de uma antiga fábrica, essas relações com o espaço eram outras. A intervenção de Gross com a frase luminosa da obra Eu Sou Dolores, naquele espaço [que era parte de uma unidade provisória], dialogava com o contexto do local. O local, naquele momento, refletia o

sua totalidade como uma entidade singular. A instalação cria uma situação em que o espectador fisicamente entra e insiste que se considere isso como uma totalidade singular" (tradução da autora). 
abandono de uma região industrial da cidade e a complexidade sociocultural da população do entorno do prédio, que sobrevivia à margem da cidade. A variedade de contextos culturais dentro da mesma cidade faz de São Paulo uma metrópole que evoca uma multiplicidade de territórios, um híbrido urbano em que se sobrepõem a uma intensa pós-modernidade os aspectos mais duros de uma extremada pobreza, ligada ao abandono urbano e social de determinados territórios da cidade.

Essa obra de Gross fazia parte do projeto Arte/Cidade Zona Leste, no qual suas poucas palavras tinham uma força poética, política, muito potente como obra de arte que não se encerra em si mesma. Gross propõe o debate a partir de elementos constitutivos de sua linguagem plástica, sensorial, ou seja, com a instalação de uma frase luminosa em um local específico, e, a partir dela, são ativados no ambiente novas relações de sentidos perceptivos e conceituais. Entretanto, é importante destacar que esse debate crítico [e político] com a cidade não é determinante, pois em sua poética esse discurso crítico é sutil, e quase silencioso para alguns.

De fato, a maioria das obras com palavras luminosas de Gross pode ser percebida apenas como um objeto plástico que envolve sensorialmente o espectador, no qual a complexidade de sua narrativa poética pode passar despercebida. Contudo, a artista oferece suas palavras luminosas como um jogo poético para quem quiser ou não participar. Uma instigação que atua como um livro aberto em um poema para quem quiser ler, sentir, e construir relações entre palavras, e o espaço. Esse jogo poético aparece em várias de suas obras quando utiliza suas palavras com nome de mulheres, ou outras como nas obras Se Vende e Hotel, carregadas de um discurso crítico que sutilmente convida a uma experiência plástica pela força de suas cores, dimensões e formas. E que, no diálogo com a arquitetura, completa sua poética conceitual para além do objeto. Essa instigação poética em Eu Sou Dolores se dá a partir de uma conversa com o prédio e a cidade. Gross instala uma frase que ao mesmo tempo pode ser lida tanto de dentro como de fora do prédio. E desse modo, ao possibilitar a experiência de diversos pontos de vista, a obra problematiza múltiplos territórios subjetivos, poéticos. No $E u$ [que fica do lado de fora] a artista estabelece um diálogo com o espaço da cidade e pode evocar na externalidade de sua locação um sentido de pertencimento para além da estrutura do prédio. Entretanto, no Eu Sou 
Dolores [visto de dentro do prédio], completando seu sentido como frase de identificação, criam-se outros territórios poéticos, vistos agora a partir de uma experiência do espaço interno. Assim, cada ponto de vista gera inúmeras metáforas possíveis ao se vivenciar diferentes dimensões conceituais, plásticas e sensoriais.

A sutileza desses jogos poéticos que Gross ativa na experiência do espaço está presente em muitas de suas obras. Essa sutileza faz parte de uma poética que não apenas utiliza palavras, mas uma variedade de meios, procedimentos que exploram diferentes materiais e formas ao longo dos anos. Seus jogos poéticos conversam com a cidade, com a arquitetura e os ambientes. Gross, em intervenções nos espaços das cidades, como nas obras Fonte/Foz e Cascata, dialoga com o desenho geográfico, histórico e sociocultural das cidades de Laguna e Porto Alegre, respectivamente. São intervenções plásticas que se expandem conceitualmente, convertendo-se pelo uso urbano cotidiano em praça e escada, ao serem elaboradas e instaladas para promover espaços de convivência. Assim, desaparecem como "obra de arte" no uso cotidiano de suas funções urbanas. Isto é, ao se tornarem parte da cidade, expandem seus limites conceituais [como obra de arte] e criam novos lugares de existência. Nesse sentido, as Escadas luminosas de Gross, integradas ao cotidiano do centro cultural do SESC Belenzinho, também podem passar despercebidas por um visitante desatento, envolvido nos afazeres diários de um centro comunitário. No entanto, quem se dispõe a olhar e caminhar entre suas linhas e luzes, é convidado a participar de uma experiência estética que instiga seus sentidos perceptivos e poéticos para além do objeto.

A poética de Gross cria novos sentidos perceptivos e conceituais em outro contexto de SESC Belenzinho, dez anos depois, agora reformado e pleno de ofertas de atividades de lazer e cultura para a comunidade do entorno, e para a cidade de São Paulo. Uma transformação e tanto para um local antes abandonado, desprovido de qualquer assistência. Agora sua arquitetura e materiais revelam uma ascensão sociocultural do local e da população do entorno que, diante de inúmeras ofertas de lazer e cultura, pode continuar crescendo, se desenvolvendo, e se expandindo como cidadãos em seus direitos à cultura, à educação e à saúde. Desse modo, as escadas de Gross podem evocar essa ascensão, esse acesso a outras possibilidades de existência. 
Diante desse novo SESC Belenzinho, como centro comunitário ativo, Gross explora uma nova proposição plástico-poética bem diferente das palavras luminosas de 2002. As Escadas de Gross estabelecem outra "conversa" no mesmo espaço arquitetônico, ou seja, essa conversa que se estabelece entre os elementos constitutivos da obra e o contexto do local [site specific] constrói outro diálogo estético, que agora, dez anos depois, gera novas relações e interpretações, a partir de outro contexto. Em 2012, o prédio reformado, em pleno funcionamento, recebe em média por dia, nos fins de semana, 2 mil pessoas. Tudo no espaço remete a grandes dimensões para receber seu público; uma enorme piscina ao ar livre, muitas cadeiras, mesas, estantes, grandes espaços vazios a serem ocupados. Uma enorme variedade de cursos e atividades de lazer é oferecida à comunidade em sua diversidade multicultural de uma cidade contemporânea como São Paulo.

A diversidade surge também nos sentidos metafóricos do "objeto escada", que podem aludir tanto a um elemento de construção em sua utilidade no acessar algo, como ao ato de consertar que pode indicar um sentimento de precariedade. E, nesse sentido metafórico, as Escadas de Gross podem sugerir um jogo poético no espaço do SESC, indicando uma leitura do objeto como possibilidade de acesso, integração, ligando os pontos do espaço como um rizoma, sem direções definidas, nem hierarquias lineares predeterminando posições e valores. Ao mesmo tempo, a instalação de diversas escadas naquele espaço do prédio pode aludir, poeticamente, à precariedade da situação que visa ao conserto de certos equívocos econômicos e socioculturais, como o abandono e ostracismo de certas regiões e camadas da população dos centros urbanos, estabelecendo novas conexões entre esses fragmentados setores da sociedade desconectados entre si. Conexões essas que as Escadas de Gross no SESC Belenzinho também parecem reconectar ao se utilizar de signos plásticos, que dialogam com as linhas e materiais do espaço, unificando-o como um desenho na totalidade do espaço arquitetônico. Onde os espaços dos andares, do chão, das janelas, e dos tetos distribuídos na arquitetura como fragmentos desconexos são integrados visualmente através das novas relações criadas a partir das luzes e linhas das escadas. O objeto escada de Gross, ao se refletir nas paredes de vidro em volta, e no chão, cria outras escadas luminosas, e evoca um universo 
mágico, a transfiguração de um real em múltiplas imagens. Assim, a obra expande seu sentido conceitual, metafórico e construtivo em um universo sensorial, plástico, de sombras, reflexos, repetições de luzes, volumes e linhas, que, ao seguir para além do espaço, o recria.

Desse modo, uma diversidade de formas e tamanhos se transforma em desenhos de luzes no espaço, ampliando sentidos perceptivos e conceituais. E o que em um primeiro momento é visualizado como formas definidas, e reconhecidas como um objeto do ofício de construir, a escada passa a atuar como um dispositivo plástico que ativa toda uma nova percepção do espaço, integrando visualmente os quatro pavimentos da torre, o subsolo e as paredes de vidro das janelas. Surge assim toda uma nova possibilidade de leitura do espaço, propondo um novo desenho, uma leitura da linha que estrutura e organiza um jogo plástico e poético que dialoga com toda a arquitetura do prédio e seus materiais.

A maestria com que Carmela Gross ativa sua poesia no espaço é elaborada através de uma linguagem plástica que explora a linearidade na diversidade de obras ao longo de seu percurso plástico, de modo que, através da linha que estrutura a obra, ativa [no espaço] um equilíbrio e uma harmonia do pensamento espacial do desenho. Sendo assim, em contínua pesquisa estética que se inicia em experimentações com o desenho e com a escultura em meados dos anos 1960 e na década de 1970, a artista segue um percurso singular de pesquisa plástica com o desenho, no qual incorpora questões da pintura em suas pinturas-objetos, nos anos 1980, depois explora instalações em ambientes e intervenções nas cidades. E, a partir dos anos 2000, inicia sua pesquisa plástica com lâmpadas e letras luminosas, momento em que atinge uma síntese poética que revela toda a amplitude dessa pesquisa. É interessante perceber o quanto de cada experiência plástica dessa pesquisa constante de Gross, ao longo dos anos, está presente na sua escrita plástica no diálogo poético com o ambiente do SESC. Em Escadas, o espaço arquitetônico é investigado, pensado e trabalhado a partir de um olhar do desenho. A artista constrói seu vocabulário através de uma leitura das distâncias entre os espaços, ritmados entre linhas, que estão presentes tanto nas estruturas de madeira que recortam o teto, como nas janelas, no chão de vidro, e nas paredes modulares dos quatro pavimentos. Um vocabulário de linhas e formas 
que desenham diversas escadas de luzes brancas de neon de tamanhos diferentes, que funcionam como elementos de sua escrita plástica no espaço. Uma escrita que estabelece um diálogo de linhas e formas [que nascem do chão e se transformam em imensas escadas] para construir novas relações com o espaço, suas linhas e materiais. Assim, as escadas de Gross atuam como metáforas plásticas de um objeto que acessa, desce, sobe, se repete para todos os lados, diferentes ângulos de visão e pontos de vista, interligando todos os andares, paredes, tetos, pilares, janelas em um vão, que ao centralizar as linhas de conexão amplia e unifica o espaço. E desse modo, o que pode ser vivenciado como experiência estética que ativa a integração do ambiente, explora não somente o desenho arquitetônico do prédio, mas o próprio conceito de um espaço comunitário.

No entanto, uma afirmação de que pode haver uma integração visual do ambiente, ativado pela obra de Gross, seria descuidada diante da complexidade do espaço e da poética da artista. O que se pretende aqui é explorar a diversidade de olhares, como entendimentos provisórios de relações poéticas plásticas e conceituais das forças que atuam na obra Escadas de Gross. A obra instala no espaço do átrio da torre uma diversidade de pontos de vista, que gera uma infinita multiplicidade de olhares, conexões e entendimentos ao se caminhar pelo espaço do SESC Belenzinho. Esses olhares, a cada novo movimento, criam novas percepções, relações, intimidades e estranhamentos que ativam múltiplos territórios poéticos. E o fato de que a cada deslocamento surge a possibilidade de se estabelecer uma nova experiência estética, um novo entendimento, nos remete a questões da arte contemporânea, em que a multiplicidade de pontos de vista coexiste em um universo complexo de fluxos e forças poéticas. Escadas, como muitas obras de arte contemporâneas, explora a complexidade dessa diversidade de olhares, conexões e entendimentos, em que os fragmentos atuam como forças poéticas que coexistem a partir de um contexto diferente. Assim, dependendo do ponto de vista e das relações do observador com esses fragmentos, ativa-se no espaço uma multiplicidade de experiências plástico-poéticas.

Portanto, sem cair em um reducionismo de que haveria apenas uma forma de entendimento de sua força poética, é preciso destacar que a reflexão que surge a partir 
de uma leitura dessa obra não pretende abarcar a multiplicidade de pontos de vista que ela oferece. Apenas indicar caminhos de leituras possíveis, como as escadas que direcionam linhas luminosas no espaço, ora formatando escadas que se transformam a cada movimento em outras linhas ou quadrados, ora se desdobrando em outras escadas, que conectam e desconectam espaços da arquitetura. As Escadas de Gross ativam no espaço de convivência do SESC Belenzinho fluxos de ideias e sentidos provisórios, que se estabelecem e se rompem a cada novo olhar, a cada novo entendimento, em uma multiplicidade de narrativas possíveis desses territórios poéticos que a cada deslocamento cria novos lugares de existência. 


\section{Considerações finais}

Carmela Gross, ao longo de sua trajetória artística, em uma pesquisa constante de materiais, formas, cores, sentidos e metáforas, propõe experiências plásticas que se relacionam com questões do desenho, da pintura, e dos ambientes, de modo que ao longo dos anos cria um vocabulário plástico próprio, uma escrita plástica. Gross com sua escrita plástica constrói narrativas poéticas que ampliam percepções e conceitos da arte, problematizando os espaços institucionais das artes, e as cidades. A multiplicidade simbólica das obras da artista atua no espaço urbano, e nos museus, como jogos estéticos, a serem experimentados, estabelecendo tanto relações poéticas com a percepção do espaço e com as problemáticas da arte contemporânea, como também dialoga com as questões sociais e políticas dos centros urbanos. São territórios que atuam independentemente uns dos outros, e que promovem uma constante definição subjetiva de um lugar poético, dependendo da relação que cada espectador estabelece com a obra.

Em uma pesquisa em que o objeto é uma poética contemporânea, em que não há nada a ser compreendido separado da experiência, mas vivenciado, incluído na obra, deve-se buscar um "modelo" apropriado para tratar dessa complexidade. Nesse intuito, a presente dissertação, para contribuir com maior compreensão da complexidade de sua poética, buscou entrar em contato com a obra da artista na experimentação de um mapear que, ao destacar algumas obras, trouxe um recorte que revela seus deslocamentos poéticos, sem capturar sentidos por meio de uma interpretação. Desse modo, foi possível trazer as problemáticas em desenvolvimento a partir de cada trabalho, apreendendo as questões e os conceitos que surgiram, através de uma relação rizomática entre as obras.

O presente estudo não pretendeu abarcar a pluralidade da poética de Carmela Gross, apenas sugere caminhos de leituras possíveis ao explorar as relações plásticas, 
sensoriais e conceituais a partir de um determinado recorte dos trabalhos da artista. Assim, constrói uma cartografia poética que se configura de múltiplos olhares, sentidos e conexões diante de sua singularidade artística. No intuito de não reduzir a força de sua poética na condução de apenas um caminho linear, vertical e [interpretativo] de entendimento da complexidade da Obra de Gross, esta dissertação apresenta em sua totalidade cartográfica a diversidade de olhares e reflexões como entendimentos provisórios, a cada deslocamento poético. Devido ao fato de serem fluxos subjetivos, esses entendimentos [temporários, provisórios] podem gerar interações diferentes a cada nova percepção [e compreensão] das forças que atuam em sua poética. Carmela Gross abre seu trabalho ao mundo com uma potente poesia plástica que convida o espectador a explorar uma rede de fluxos poéticos, que, devido aos imprevistos gerados pelos novos sentidos dos signos [e situações] deslocados de seus significados, criam novas convergências. Portanto, a potência de significação, a associação, o praticar simbólico e o deleite quase tátil dos sentidos que os trabalhos da artista provocam devem ser preservados como indagações poéticas que nunca se esgotam completamente. Sendo assim, na intenção de contribuir para maior compreensão da poética da artista, a presente dissertação propõe uma cartografia que promova a continuidade dessa rica interlocução que Carmela Gross em seus territórios poéticos estabelece com a arte, com o homem e o mundo. 


\section{6}

\section{Referências bibliográficas}

ALVARADO, Daisy Valle Machado Peccinini de. Figurações Brasil anos 1960: neofigurações fantásticas e neossurrealismo, novo realismo e nova objetividade. São Paulo: Itaú Cultural/Edusp, 1999.

AMARAL, Aracy A. Textos do Trópico de Capricórnio: artigos e ensaios (1980- -2005) - Vol. 3: Bienais e artistas contemporâneos no Brasil. São Paulo: Editora 34, 2006.

AMARAL, Aracy. Carmela Gross 1993: um olhar em perspectiva. In: Carmela Gross. Hélices. Rio de Janeiro: MAM, 1993.

ANJOS, Moacir dos. Projeto sem fim. In Carmela Gross. Recife: Museu de Arte Moderna Aloísio Magalhães, 2003.

ARENDT, Hannah. A condição humana. 11a edição. Rio de Janeiro: Forense Universitária, 2010.

ARGAN, Giulio Carlo. História da Arte como história da cidade. $4^{\mathrm{a}}$ edição. São Paulo: Martins Fontes, 1998.

BANDEIRA, João (org.). Carmela Gross. CARNE. São Paulo: Centro Universitário Maria Antonia, 2006. 
BARBOSA, Ana Mae e AMARAL, Lilian (org.). Interterritorialidade; mídias, contextos e educação. São Paulo: Editora Senac São Paulo/Edições SESC SP, 2008.

BASBAUM, Ricardo (org.). Arte contemporânea brasileira: texturas, dicções, ficções, estratégias. Rio de Janeiro: Rios Ambiciosos/Contra Capa, 2001.

BASBAUM, Ricardo. Dentro d'água. Catálogo da mostra Regist(R)os. [s.n.t.]

BASBAUM, Ricardo. Além da pureza visual. Porto Alegre: Zouk, 2007. BASBAUM, Ricardo. Within the Organic Line and After. [s.n.t.] BATCHELOR, David. Minimalismo. São Paulo: Cosac Naify, 1999.

BATTCOCK, Gregory (org.). A Nova Arte. São Paulo: Perspectiva, 2002. BELLUZZO, Ana Maria. Carmela Gross. São Paulo: Cosac Naify, 2000. BELLUZZO, Ana Maria de Moraes. Carmela Gross. In: ARTISTAS brasileiros na $20^{\text {a }}$ Bienal Internacional de São Paulo. São Paulo: Fundação Bienal/Marca D’Água, 1989, págs. 58-59.

BELLUZZO, Ana Maria de Moraes. Especulações. In: Carmela Gross. São Paulo: Centro Cultural São Paulo, 1997.

BISHOP, Claire. Installation Art: A Critical History. London: Tate Publishing, 2010.

BOIS, Yve-Alain. A pintura como modelo. São Paulo: Editora WMF Martins Fontes, 2009.

BRAGA, Paula (org.). Fios soltos: a arte de Hélio Oiticica. São Paulo: Perspectiva, 2008. 
BRETT, Guy. Brasil experimental arte/vida: proposições e paradoxos. Kátia Maciel (org.). Rio de Janeiro: Contra Capa, 2005.

BRISSAC PEIXOTO, Nelson (org.). Intervenções urbanas: Arte/Cidade. São Paulo: Editora Senac São Paulo, 2002.

BRISSAC PEIXOTO, Nelson. Paisagens urbanas. São Paulo: Editora Senac São Paulo, 2004.

CALVINO, Italo. As cidades invisíveis. São Paulo: Companhia das Letras, 1990.

CARLOS, Ana Fani Alessandri; SOUZA, Marcelo Lopes de; SPOSITO, Maria Encarnação Beltrão (org.). A produção do espaço urbano: agentes e processos, escalas e desafios. São Paulo: Contexto, 2011.

CHIARELLI, Tadeu. Carmela Gross. Guia das Artes, São Paulo, n. 11, págs. 66-67, 1988.

CHIARELLI, Tadeu. Projeto Parede 10 anos - Museu de Arte Moderna de São Paulo. São Paulo: MAM, 2007.

COHN, Sergio (org.). Ensaios Fundamentais: Artes Plásticas. Rio de Janeiro: Beco do Azougue, 2010.

COTRIM, Cecilia e FERREIRA, Gloria (org.). Escritos de artistas: anos 60/70. Rio de Janeiro: Jorge Zahar Editor, 2006.

COTRIM, Cecilia e FERREIRA, Gloria (org.). Clemente Greenberg e o debate crítico. Rio de Janeiro: Jorge Zahar Editor, 2001.

DE DUVE, Thierry. Kant depois de Duchamp. Revista Arte e Ensaio 3. Revista do Mestrado em História da Arte EBA-UFRJ. Rio de Janeiro, 1998.

DE DUVE, Thierry. Kant after Duchamp. Cambridge: The MIT Press, Mass., 1996. 
DELEUZE, Gilles. A filosofia crítica de Kant. Lisboa: Edições 70, 2000.

DELEUZE, Gilles. Conversações (1972-1990). 2a edição. São Paulo: Editora 34, 1992.

DELEUZE, Gilles e GUATTARI, Félix. Mil Platôs, capitalismo e esquizofrenia. [Volumes 1 a 4]. São Paulo: Editora 34, $2008\left(4^{\mathrm{a}}\right.$ reimpressão). $1^{\text {a }}$ edição brasileira, 1997.

DIDI-HUBERMAN, Georges. O que vemos, o que nos olha. São Paulo: Editora 34, 2005.

DUARTE, Paulo Sérgio. Anos 1960: Transformações da arte no Brasil. Rio de Janeiro: Campos Gerais, 1998.

DUARTE, Paulo Sérgio. Três passagens em torno de uma instalação. In: Carmela Gross. São Paulo: Gabinete de Arte Raquel Arnaud, 2003.

FARIAS, Agnaldo. AURORA. In: São Paulo das Mil e Uma Faces. São Paulo: Galeria Olido, 2004.

FLAM, Jack (Ed.). Robert Smithson: The Collected Writings. Berkeley, Los Angeles: University of California Press, 1996.

FREIRE, Cristina. Arte conceitual. Rio de Janeiro: Jorge Zahar Editor, 2006.

FREIRE, Cristina e LONGONI, Ana (org.). Conceitualismos do Sul/Sur. São Paulo: Annablume/USP-MAC/AECID, 2009.

FERREIRA, Gloria (org.). Crítica de Arte no Brasil: temáticas contemporâneas. Rio de Janeiro: Funarte, 2006.

GUATTARI, Félix e ROLNIK, Suely. Micropolítica: cartografias do desejo. Petrópolis: Vozes, 1996. 
GIL, José. A imagem-nua e as pequenas percepções - estética e metafenomenologia. Lisboa: Relógio D’Água, 1996.

GORELIK, Adrián. O romance do espaço público. Revista Arte \& Ensaios, Rio de Janeiro (EBA-UFRJ), n. 17, 2008.

GORELIK, Adrián. Políticas de la representación urbana: el momento situacionista. Revista Punto de Vista, Buenos Aires, n. 86, 2006.

GULLAR, Ferreira. Experiência neoconcreta. São Paulo: Cosac Naify, 2007.

GUMBRECHT, Hans Ulrich. Produção de presença: o que o sentido não consegue transmitir. Rio de Janeiro: Contraponto: Editora PUC-Rio, 2010.

HAESBAERT, Rogério. O mito da desterritorialização: o fim dos territórios à multiterritorialidade. 6a edição. Rio de Janeiro: Bertrand Brasil, 2011.

JIMÉNEZ, José. A vida como acaso. Lisboa: Vega, 1997.

KOOLHAAS, Rem. Espacio Basura. Barcelona: Editorial Gustavo Gili, SL. Colección GGmínima, 2007.

KOOLHAAS, Rem. La ciudad genérica. Barcelona: Editorial Gustavo Gili, SL. Colección GGmínima, 2006.

KOOLHAAS, Rem. Nova York delirante: um manifesto retroativo para Manhattan. São Paulo: Cosac Naify, 2008.

KOOLHAAS, Rem and BRUCE, Nau. S, M, L, XL. - O.M.A. New York: The Monacelli Press, 1995.

KRAUSS, Rosalind E. Caminhos da escultura moderna. São Paulo: Martins Fontes, 1998. 
KRAUS, Rosalind E. The Originality of the Avant-Garde and Other Modernist Myths. London: MIT Press, 1986.

KRAUSS, Rosalind. O fotográfico. Barcelona: Editorial Gustavo Gili, SA, 2002.

KRAUSS, Rosalind. Perpetual Inventory. Cambrigde: The MIT Press, 2010.

KRAUSS, Rosalind. A escultura no campo ampliado. Revista Gávea, Rio de Janeiro (PUC-Rio), n. 1, págs. 87-93, 1984.

KRAUSS, Rosalind. "La ruse de Brancusi". In: Qu'est-ce que la sculpture moderne. Paris: Centre Georges Pompidou, 1986. Tradução de Cecilia Cotrim [mimeo.].

KWON, Mywon. Um lugar após o outro: anotações sobre site-specificity, Revista Arte \& Ensaios, Rio de Janeiro (EBA-UFRJ), n. 17, págs. 167188, 2008.

LAGNADO, Lisette. Carmela Gross pesquisa os limites da pintura. Folha de São Paulo, São Paulo, pág. E4, 14 de agosto de 1990.

LEIRNER, Sheila. Carmela Gross pinta fachada em Paris. O Estado de São Paulo, São Paulo, Caderno 2, 26 de maio de 2004.

LOPES, Fernanda. A experiência Rex: Éramos o time do Rei. São Paulo: Alameda, 2009.

LIMA, Sueli de (org.). Experiência crítica - textos selecionados: Ronaldo Brito. São Paulo: Cosac Naify, 2005.

MACHADO, Roberto. Deleuze, a arte e a filosofia. Rio de Janeiro: Jorge Zahar Editora, 2009. 
MAMMÌ, Lorenzo. Concreta 56: A Raiz da Forma. In: Sergio Cohen (org.). Ensaios Fundamentais: Artes Plásticas. Rio de Janeiro: Beco do Azougue, 2010.

MAMMì, Lorenzo. Instantes e Movimentos: Carmela Gross e lole de Freitas. Estudos avançados 16(44), para exposição Trabalho de Artista, 2002. Disponível no site do Instituto Itaú Cultural.

MAMMİ, Lorenzo. Desenhar, encarnar e organizar. In: Carmela Gross. CARNE. São Paulo: Centro Universitário Maria Antonia, 2006.

MATESCO, Viviane. Corpo, imagem e representação. Rio de Janeiro: Jorge Zahar Editor, 2009.

MENDES, Camila Faccioni. Paisagem urbana: uma mídia redescoberta. São Paulo: Editora Senac São Paulo, 2006.

MERLEAU-PONTY, Maurice. A fenomenologia da percepção. São Paulo: Martins Fontes, 1999.

MERLEAU-PONTY, Maurice. O olho e o espírito. São Paulo: Cosac Naify, 2004.

MERLEAU-PONTY, Maurice. A natureza. São Paulo: Martins Fontes, 2000 .

MESQUITA, IVO. Carmela Gross, um corpo de ideias. Curadoria e texto de Ivo Mesquita. São Paulo: Pinacoteca do Estado, 2010.

MILLIET, Maria Alice. O que resta da noiva? In: Por que Duchamp? Leituras duchampianas por artistas e críticos brasileiros. São Paulo: Itaú Cultural/Paço das Artes, 1999, págs. 32-40.

MORAIS, Frederico. Arte brasileira do modernismo a contemporaneidade. Rio de Janeiro: Sul América, 1985. 
MORAIS, Frederico. Contra a arte afluente: o corpo é o motor da obra. Catálogo do Ciclo de Exposições sobre Arte no Rio de Janeiro: 7. Depoimento de uma geração 1969-1970. Rio de Janeiro, Galeria de Arte BANERJ, julho de 1986.

NAVAS, Adolfo Montejo. A constelação Artur Barrio (inscrições). [s.n.t.] NAVES, Rodrigo. O vento e o moinho. Ensaios sobre a arte moderna e contemporânea. São Paulo: Companhia das Letras, 2007.

NEGRI, Antonio e HARDT, Michael. Império. $8^{\text {a }}$ edição. Rio de Janeiro: Record, 2006.

OITICICA, Hélio. Esquema Geral da Nova Objetividade. In Sergio Cohn (org.). Ensaios Fundamentais: Artes Plásticas. Rio de Janeiro: Beco do Azougue, 2010.

OITICICA, Hélio. Hélio Oiticica. Encontros. Rio de Janeiro: Beco do Azougue, 2009.

OITICICA, Hélio. Aspiro ao grande labirinto. Org. Luciano Figueiredo, Lygia Pape e Waly Salomão. Rio de Janeiro: Rocco, 1986.

OSORIO, Luiz Camillo. Artur Barrio. Catálogo da mostra individual do artista no MAC-Niterói, agosto-setembro de 2002.

OSORIO, Luiz Camillo. Razões da crítica. Rio de Janeiro: Jorge Zahar Editor, 2005.

PAZ, Otavio. Marcel Duchamp, ou o castelo da pureza. São Paulo: Perspectiva, 2004.

PEDROSA, Mario. Mundo, homem, arte em crise. $2^{\text {a }}$ edição. Org. Aracy Amaral. São Paulo: Perspectiva, 2007.

RANCIÈRE, Jacques. El espectador emancipado. Castellón, España: Ellago Ediciones, 2010. 
REIS, Paulo Roberto de Oliveira. Exposições de arte - Vanguarda e Política entre os anos 1965 e 1970. Curitiba: Editora UFPR, 2005.

REIS, Paulo R. O. Arte de vanguarda no Brasil. Rio de Janeiro: Jorge Zahar Editor, 2006.

SALGADO, Renata. Imagem escrita. Rio de Janeiro: Graal, 1999.

SALOMÃO, Waly e OITICICA, Hélio. Hélio Oiticica - Qual é o parangolé? Rio de Janeiro: Rocco, 2003.

SANTOS, Milton. Técnica, Espaço, Tempo: globalização e meio técnico- $\quad$-científico-informacional. São Paulo: Edusp, 2008.

SENNETT, Richard. Carne e Pedra; o corpo e a cidade na civilização ocidental. 5a edição. Rio de Janeiro: Record, 2008.

SALZSTEIN, Sônia (org.). Fronteiras. São Paulo/Rio de Janeiro: Itaú Cultural/Contra Capa, 2005.

SALZSTEIN, Sônia. Desgaste, historicidade e mudança. In: Carmela Gross. Facas. Rio de Janeiro: Centro Cultural Banco do Brasil, 1994, págs. 5-7.

SCARINCI, Carlos. Carmela Gross. Revista Galeria, São Paulo, maiojunho, pág. 22-24, 1992.

SCHENBERG, Mario. Arte e Tecnologia. In: Sergio Cohn (org.). Ensaios Fundamentais: Artes Plásticas. Rio de Janeiro: Beco do Azougue, 2010.

SMITHSON, Robert. Um Passeio pelos Monumentos de Passaic, Nova Jérsei. Tradução de Pedro Sussekind. Jornal O Nó Górdio, n. 1, Rio de Janeiro, 2001. [tradução revista para publicação na revista Arte \& Ensaios].

TSAI, Eugenie (org.). Robert Smithson. The Museum of Contemporary Art, Los Angeles: University of California Press, 2004. 
VENTURI, Robert; SCOTT BROWN, Denise; IZENOUR, Steven. Aprendendo com Las Vegas. São Paulo: Cosac Naify, 2003.

ZACCAGNINI, Carla. Desenhos, desenhos: a título de prólogo. In: Carmela Gross, um corpo de ideias. Curadoria e texto de Ivo Mesquita. São Paulo: Pinacoteca do Estado, 2010.

ZANINI, Walter. Os carimbos de Carmela. Folha de São Paulo, São Paulo, 9 de julho de 1978. 
7

Anexo - Obras de Carmela Gross 


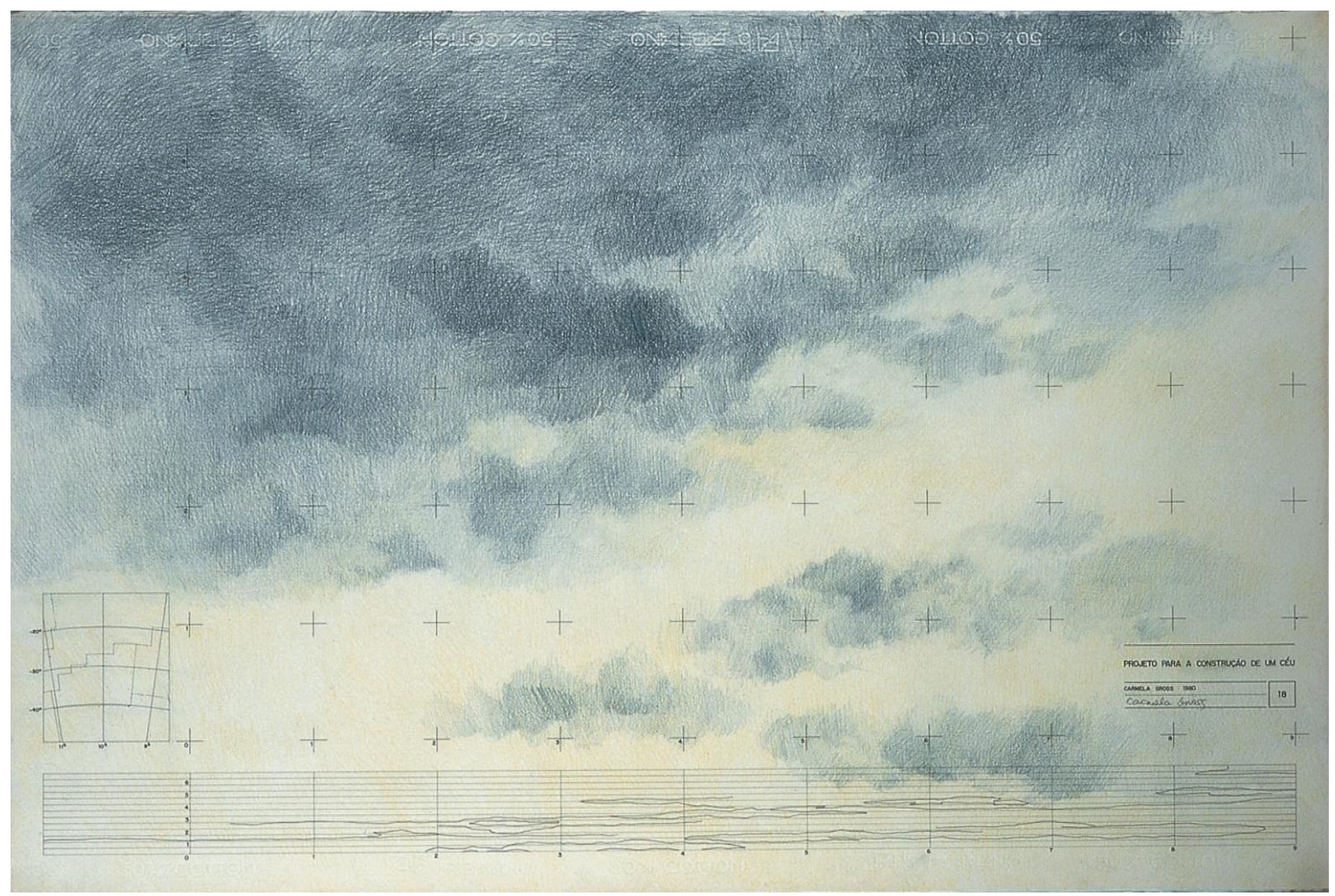

Figura 1 - Projeto para a construção de um céu

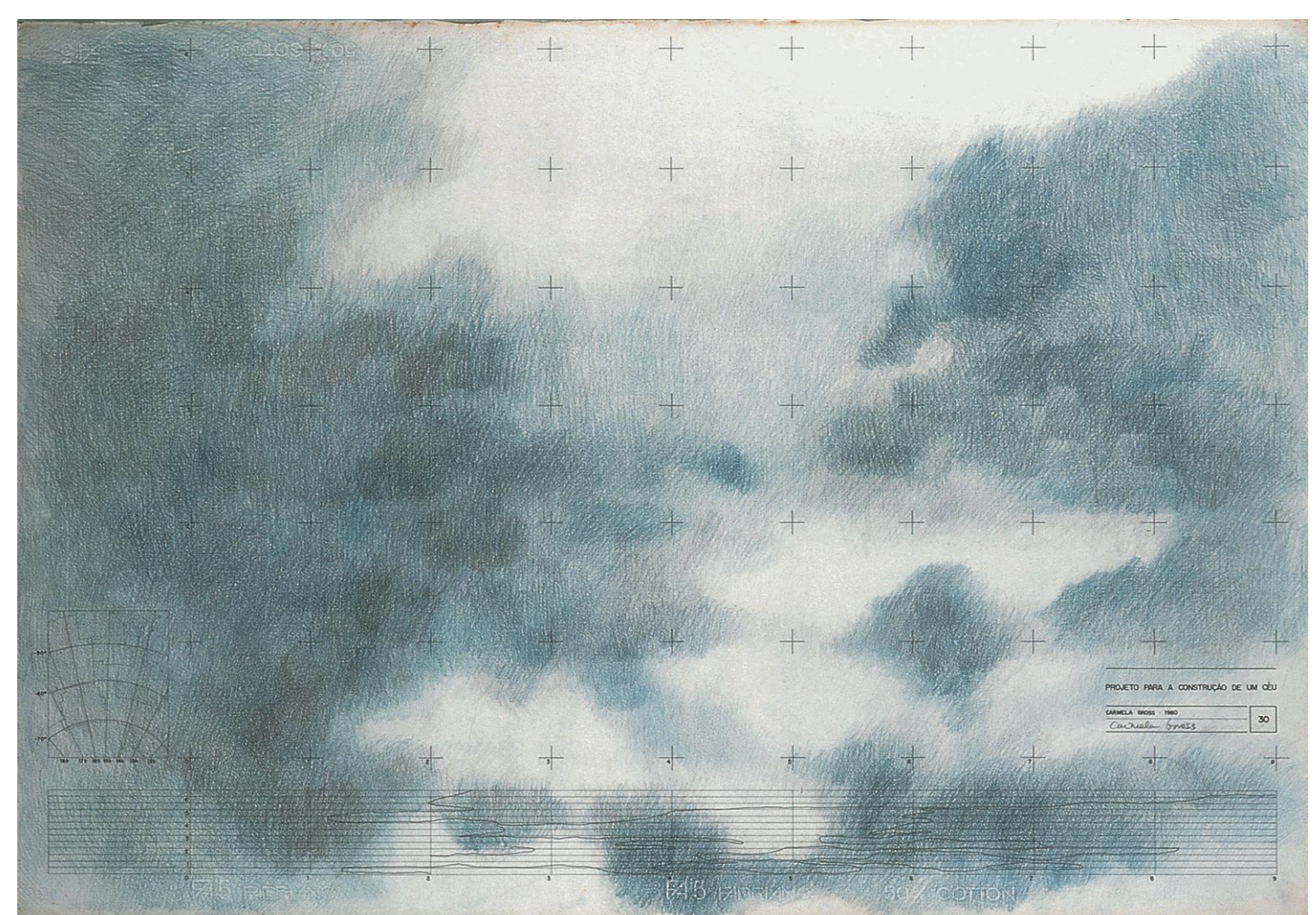

Figura 2 - Projeto para a construção de um céu 

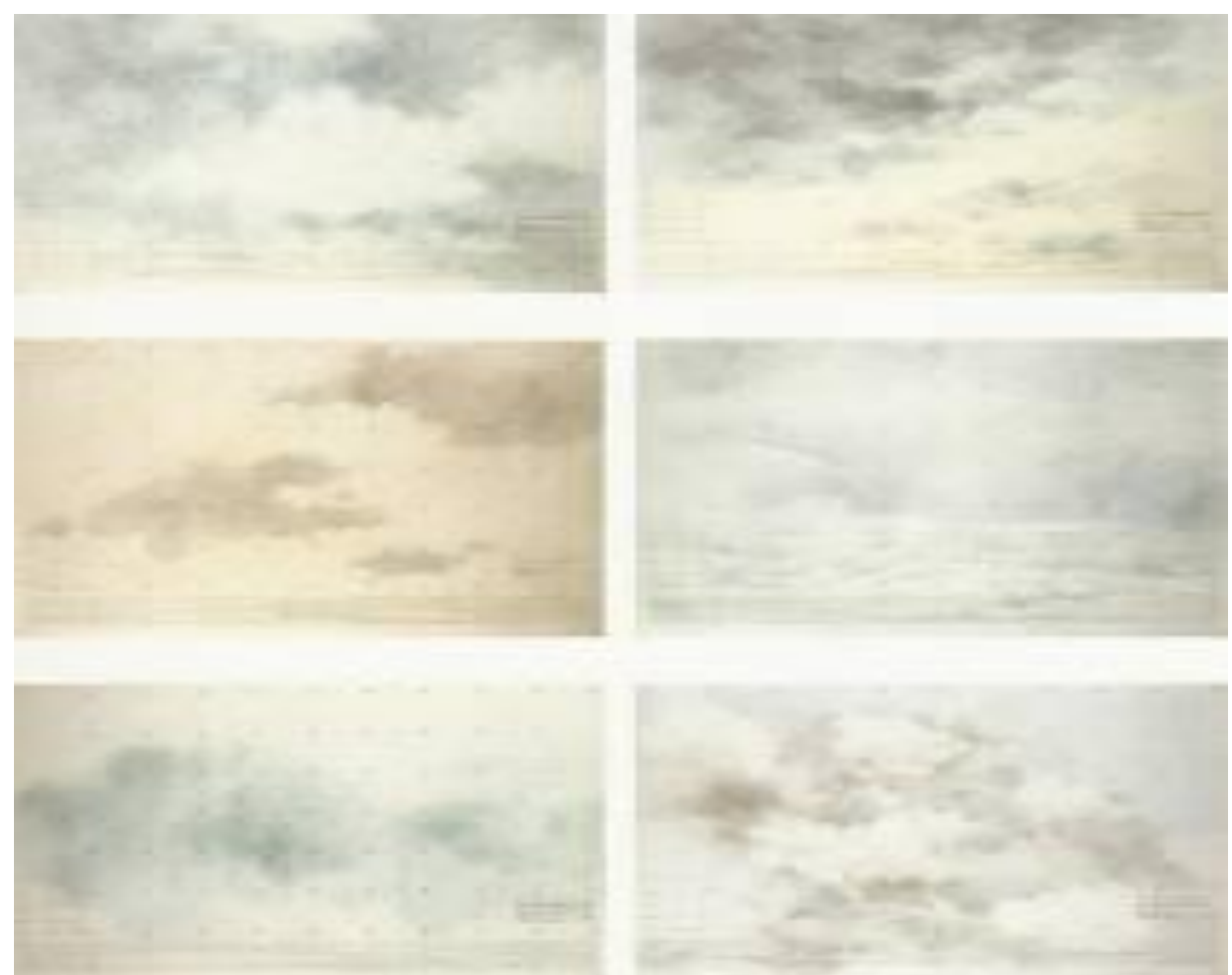

Figura 3 - Projeto para a construção de um céu

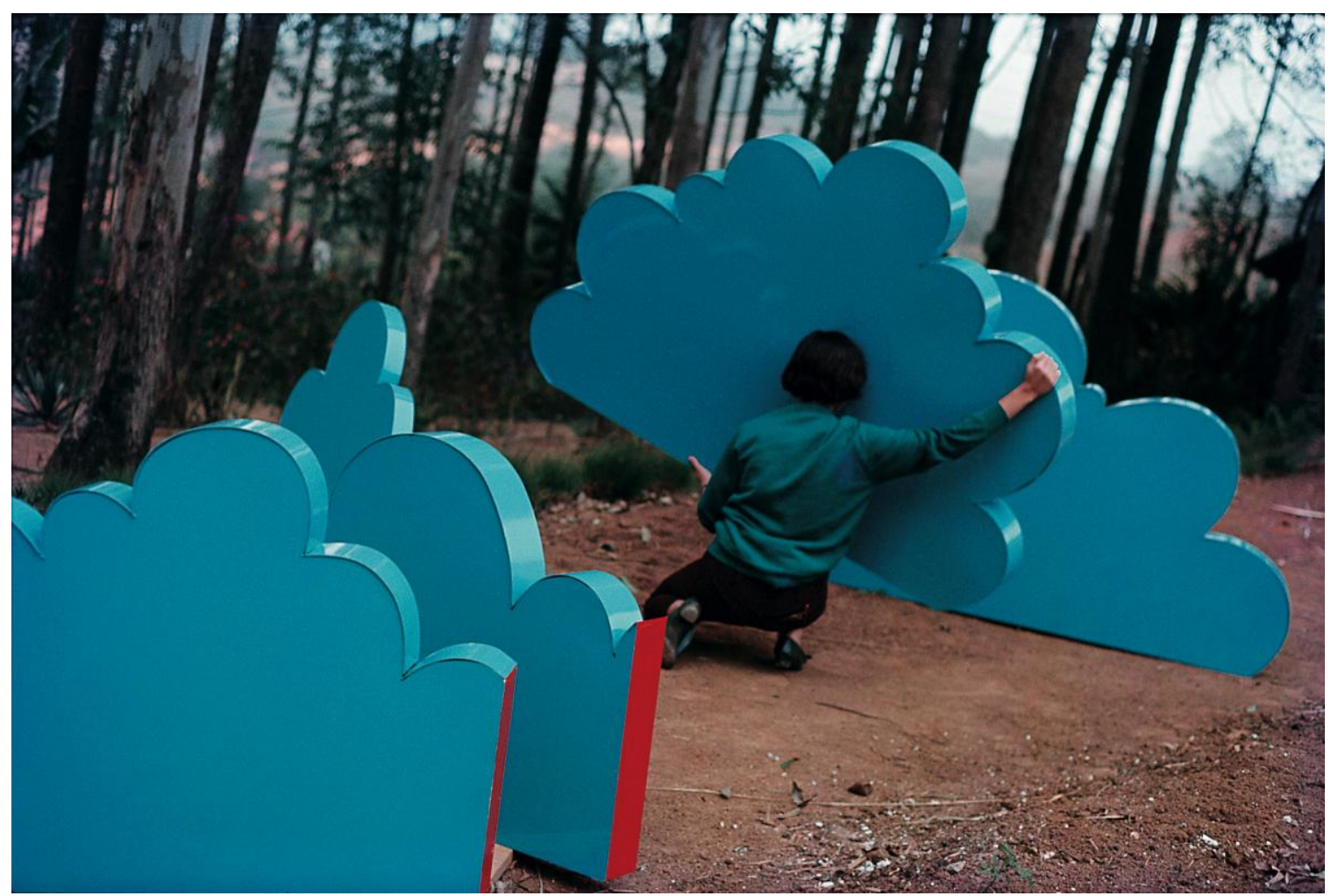

Figura 4 - Nuvens 


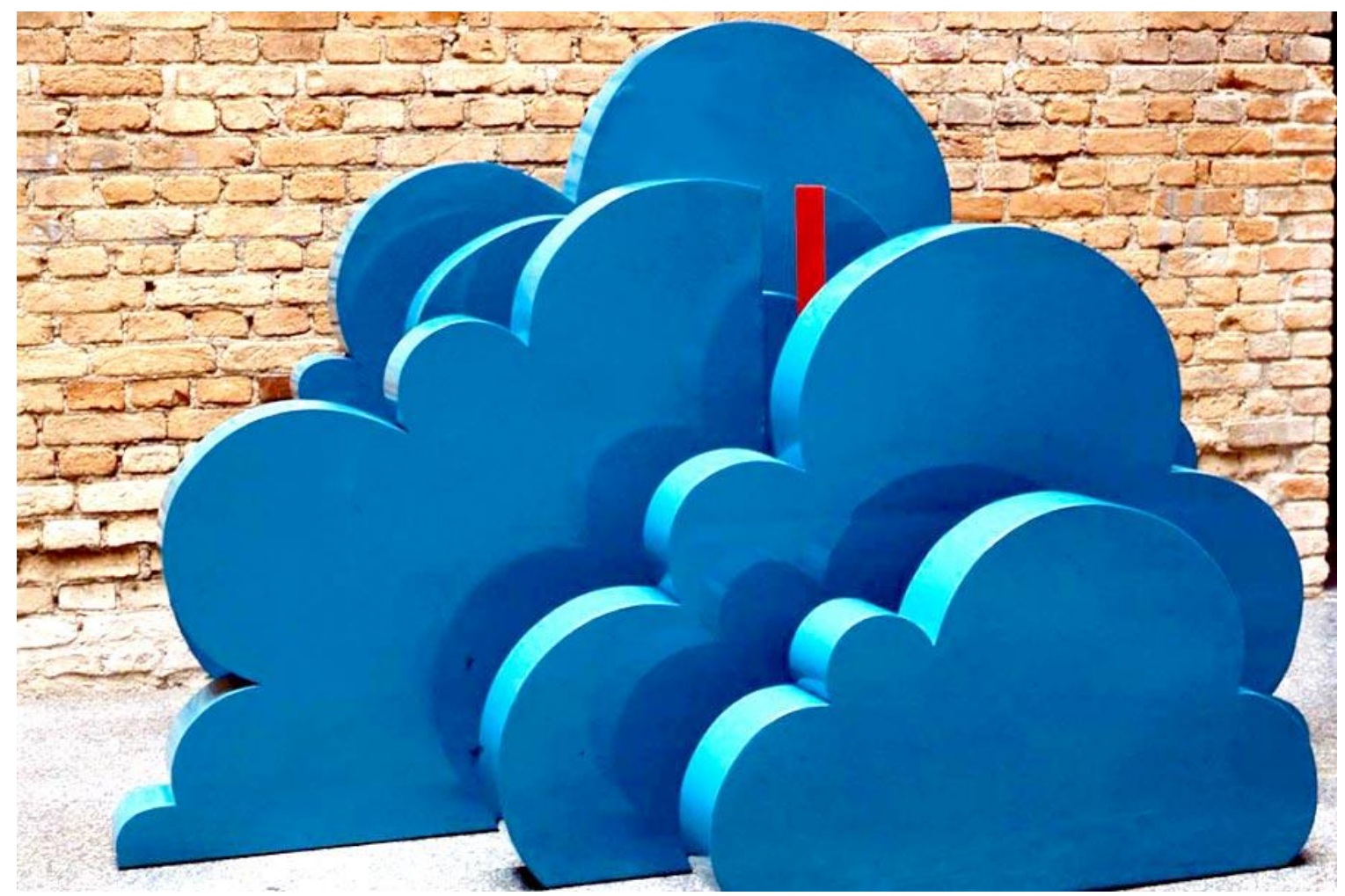

Figura 5 - Nuvens

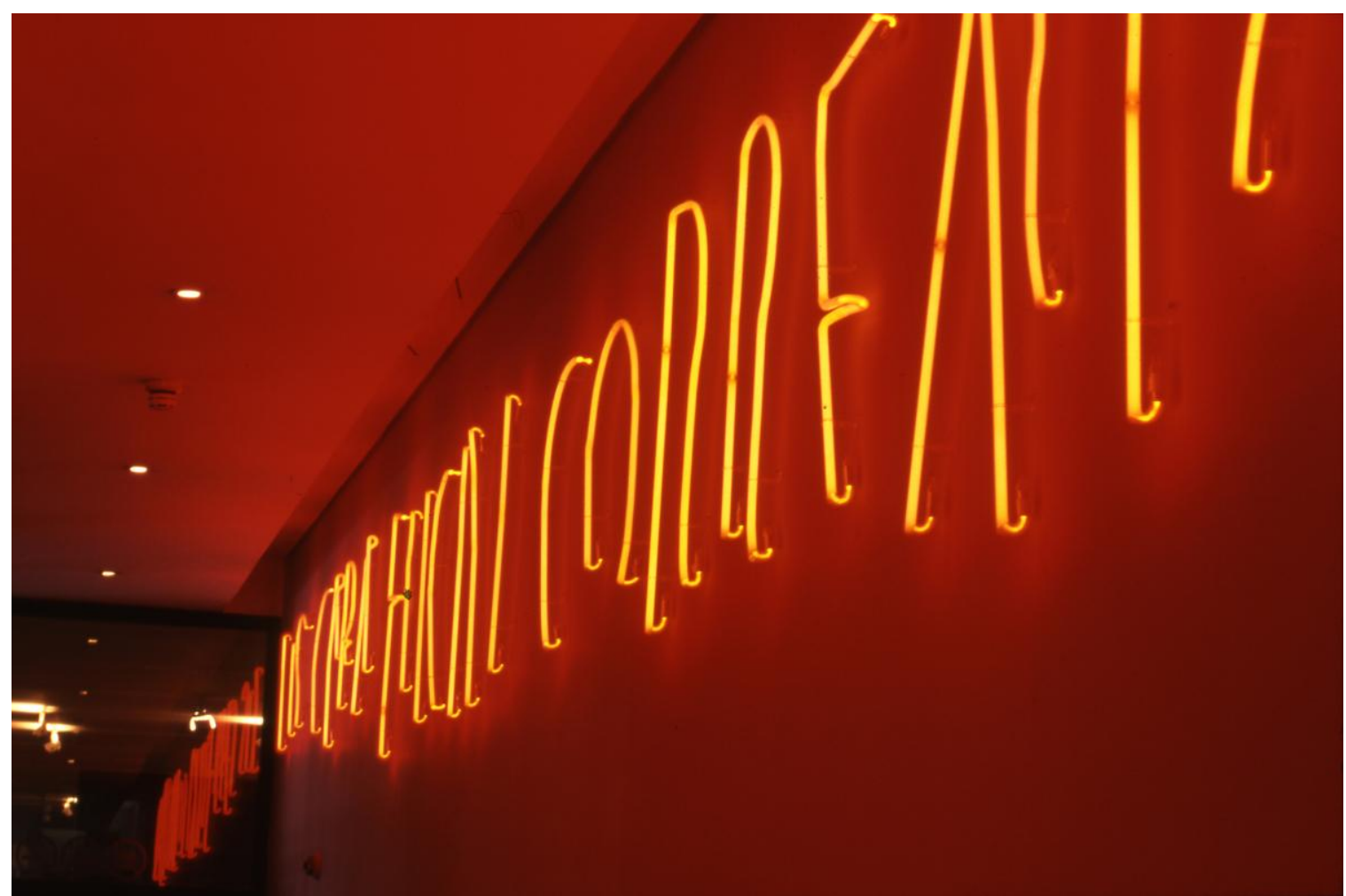

Figura 6 - Us Cara Fugiu Correndo 


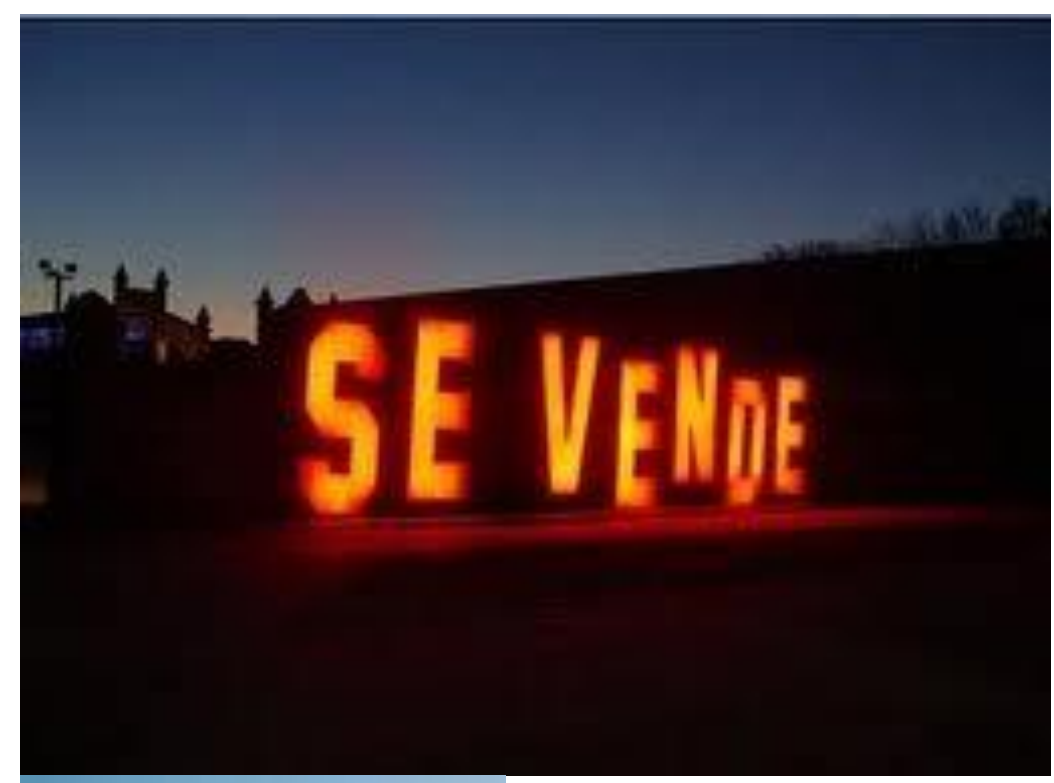

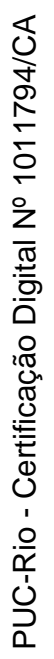

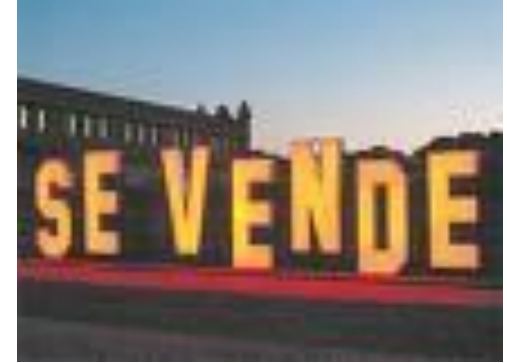

Figura 7 - Se Vende, feira de arte ARCO, Madrid

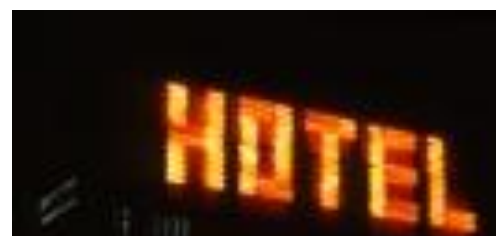

Figura 8 - Hotel 


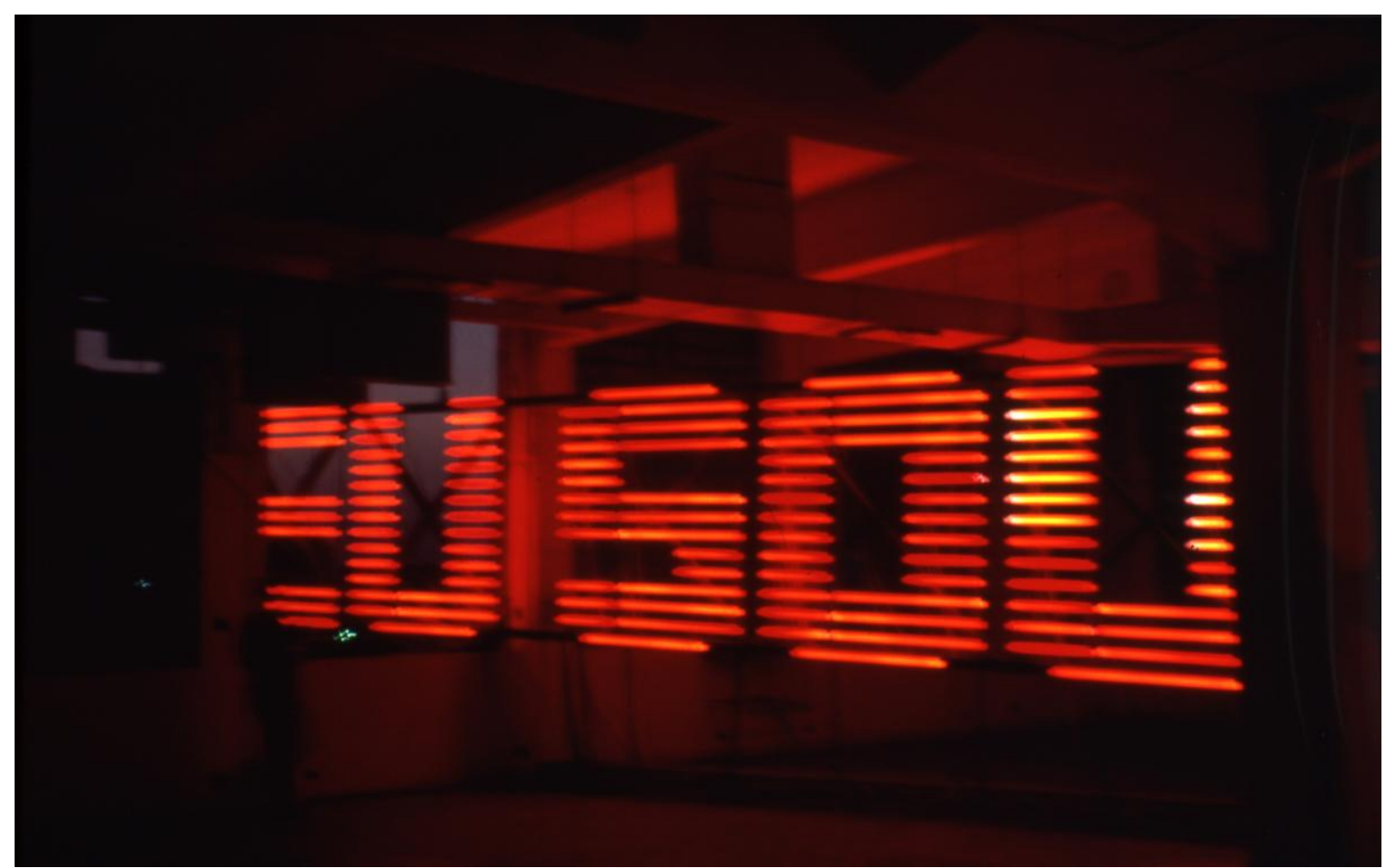

Figura 9 - Eu Sou Dolores

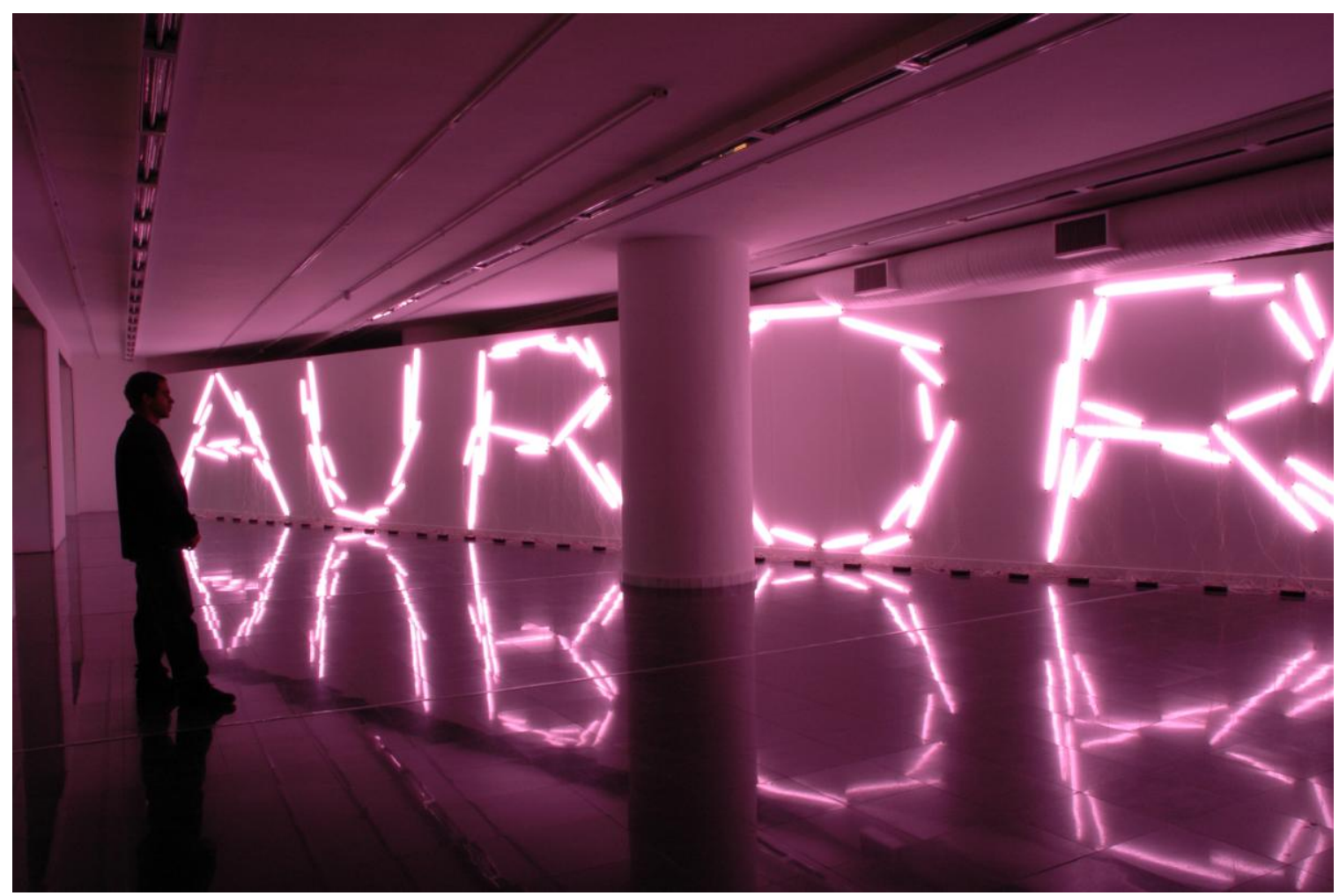

Figura 10 - Aurora 


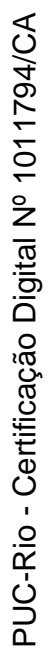

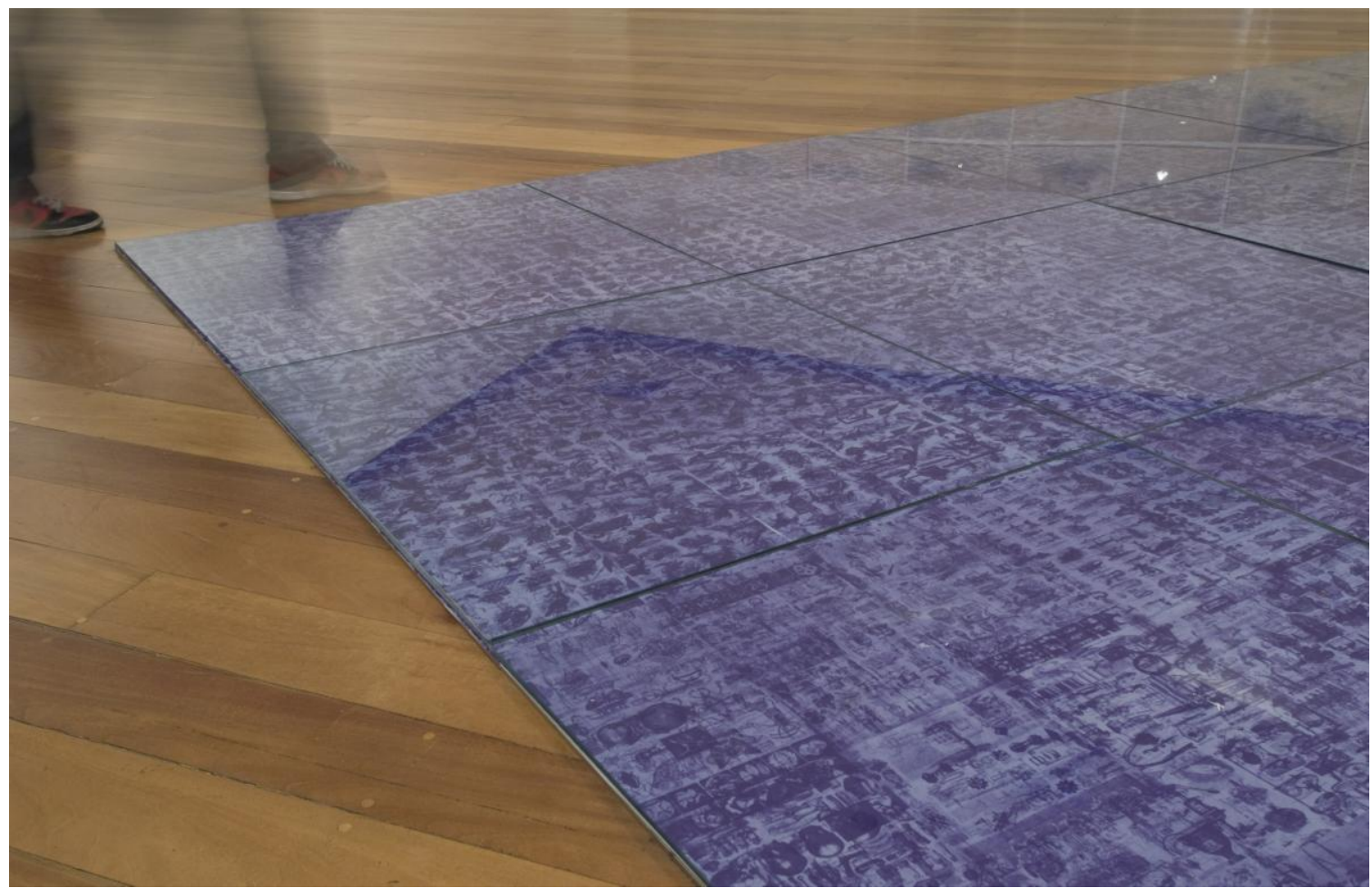

\section{Figura 11 - Corpo de ideias}

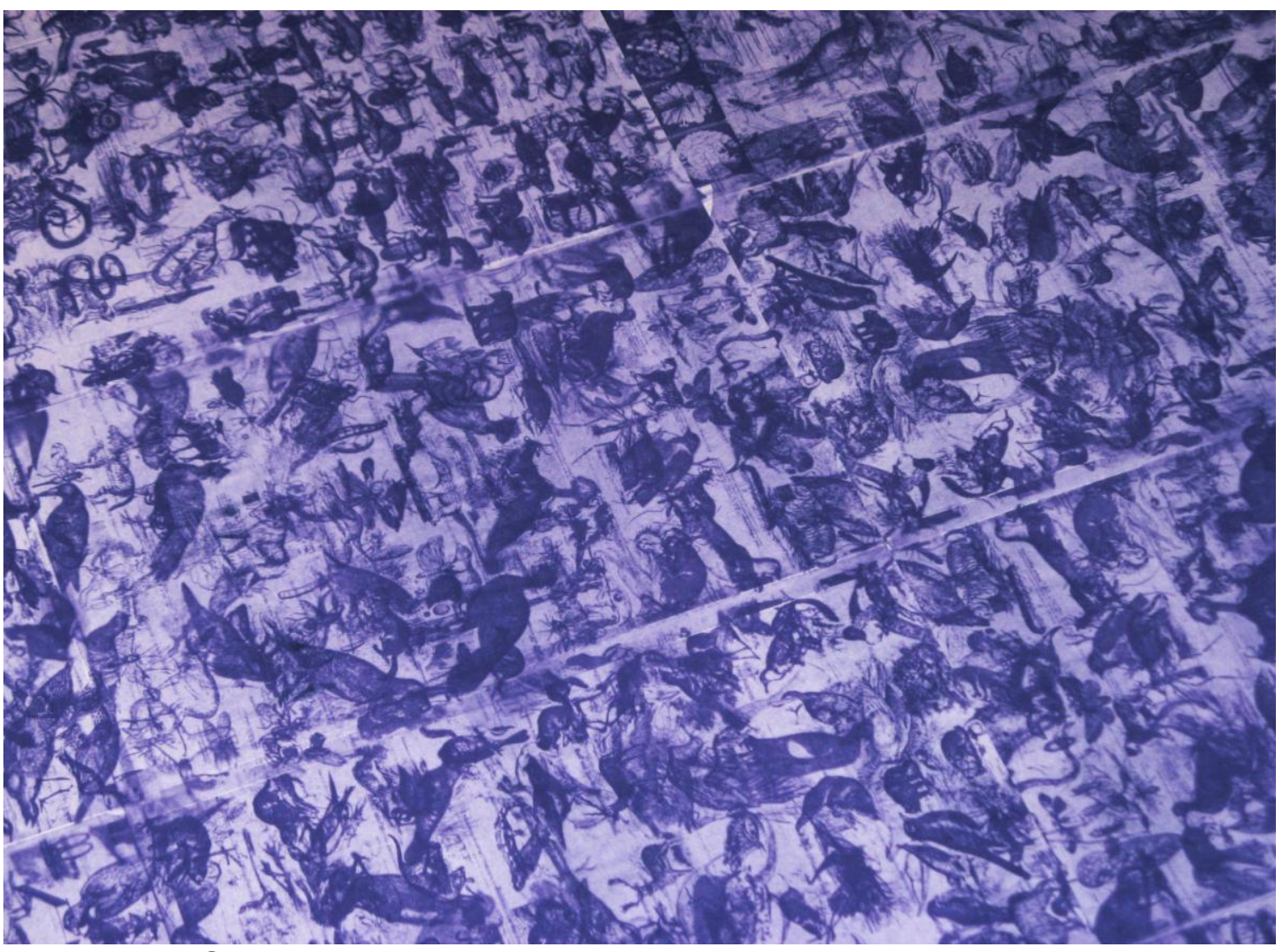

Figura 12 - Corpo de ideias 


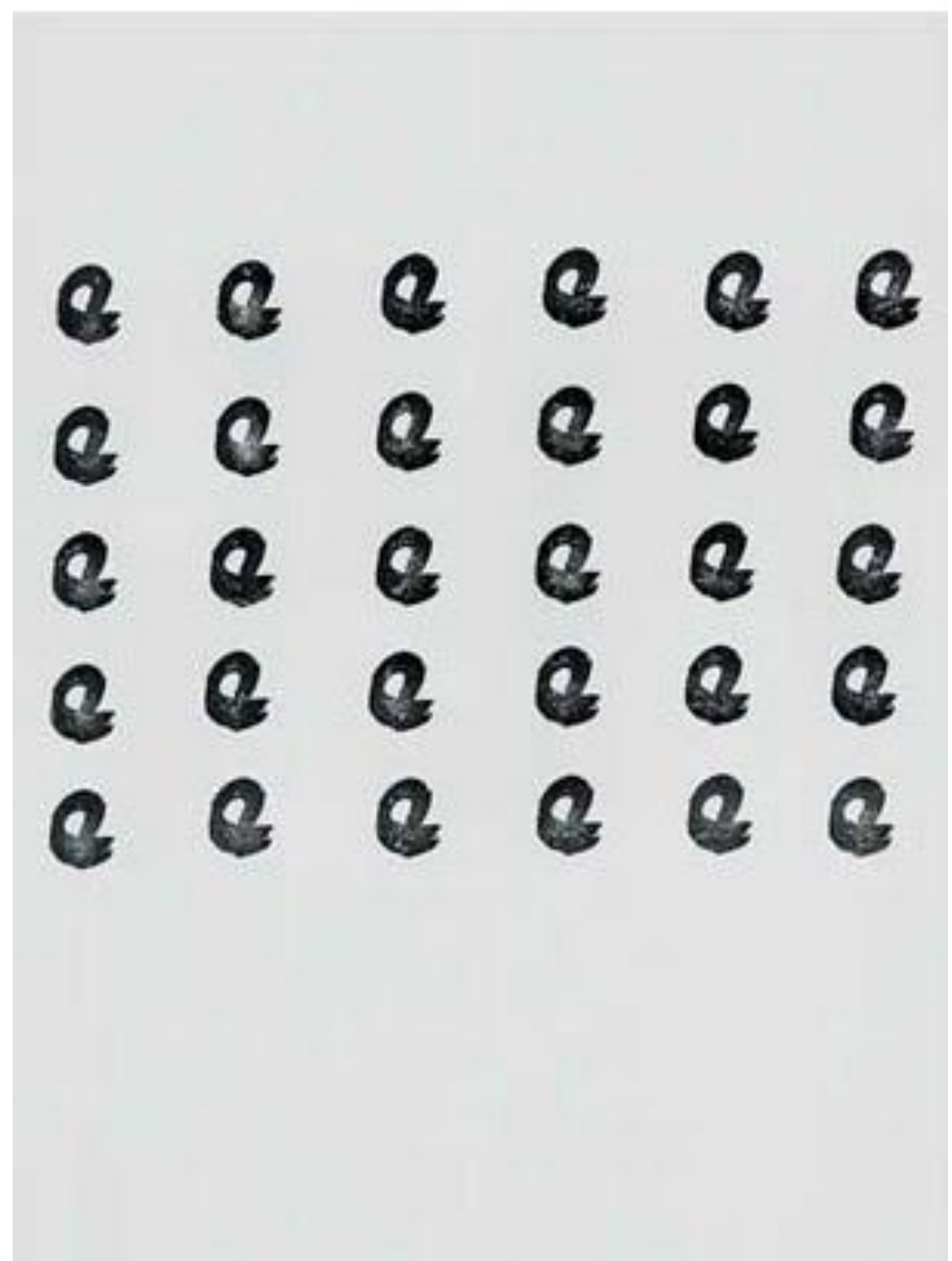

Figura 13 - Série Carimbos 

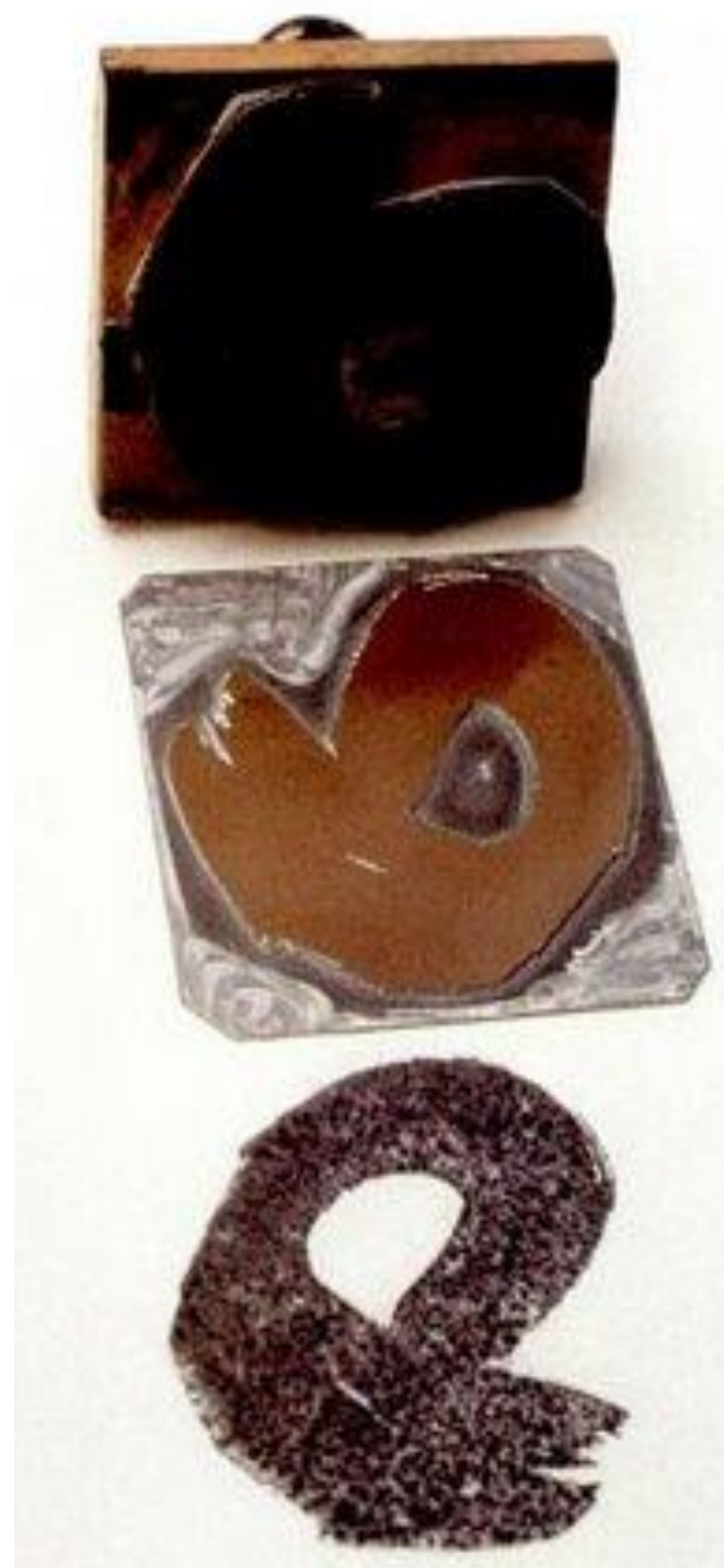

Figura 14 - Série Carimbos 


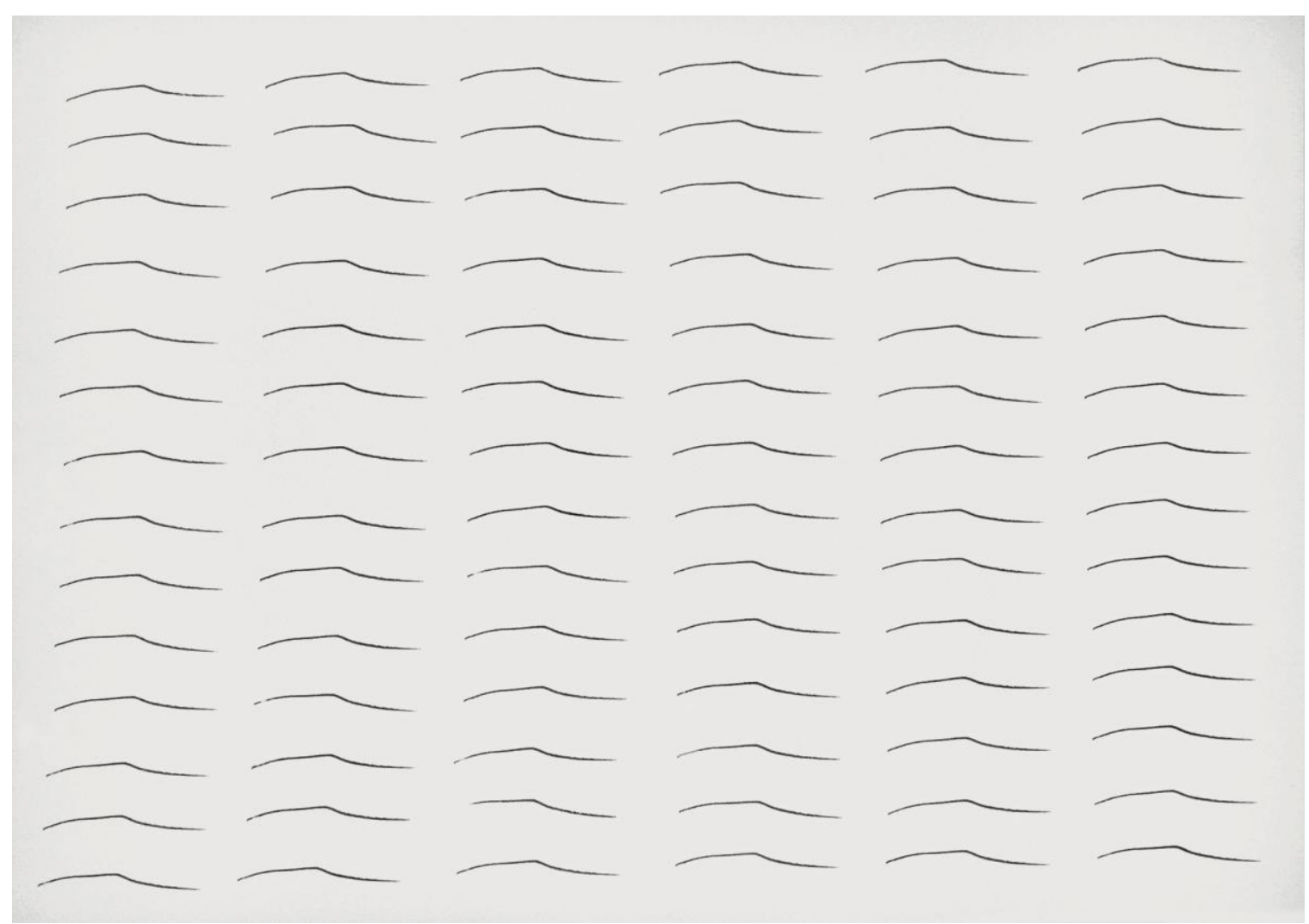

Figura 15 - Carimbos-linhas
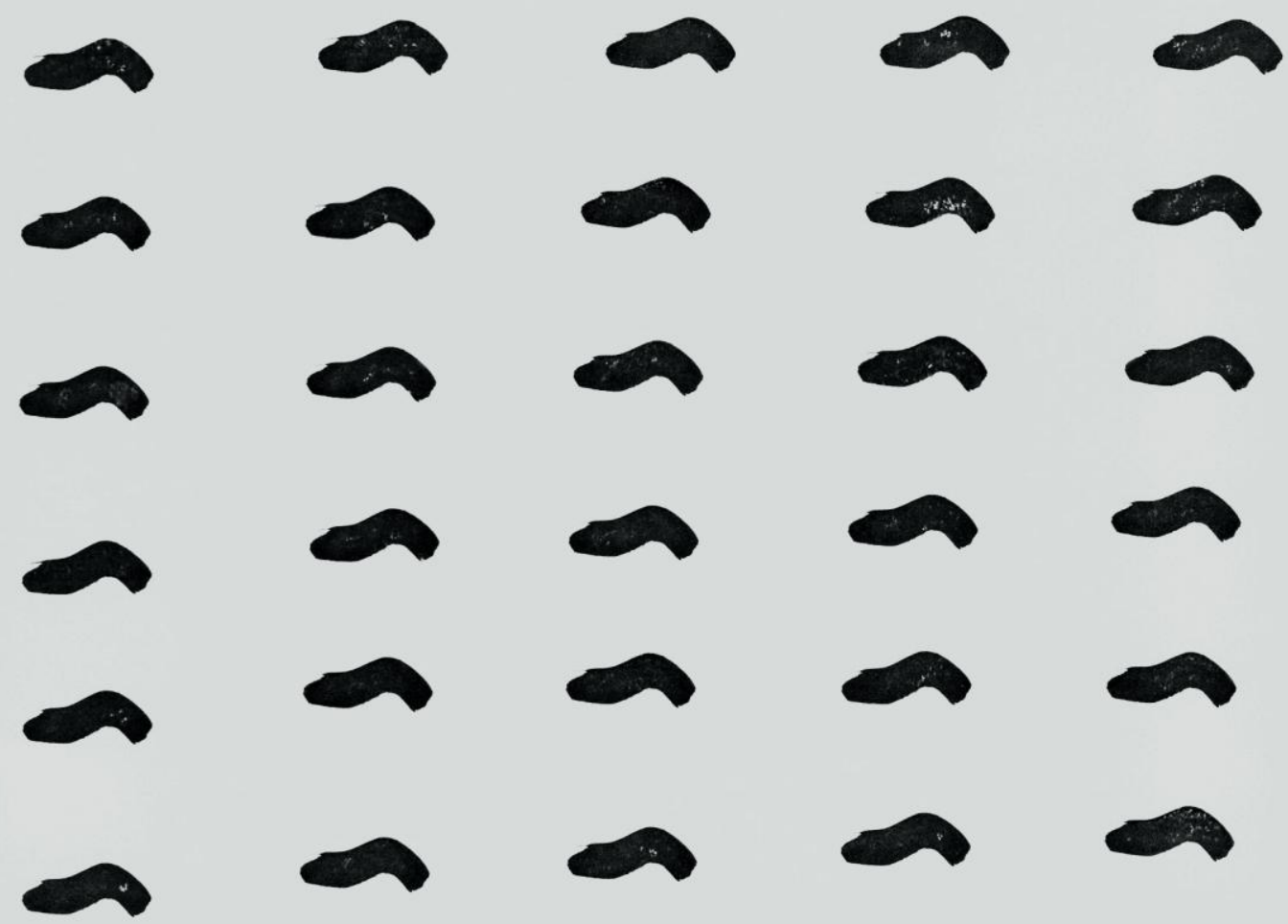

Figura 16 - Carimbos-pinceladas 

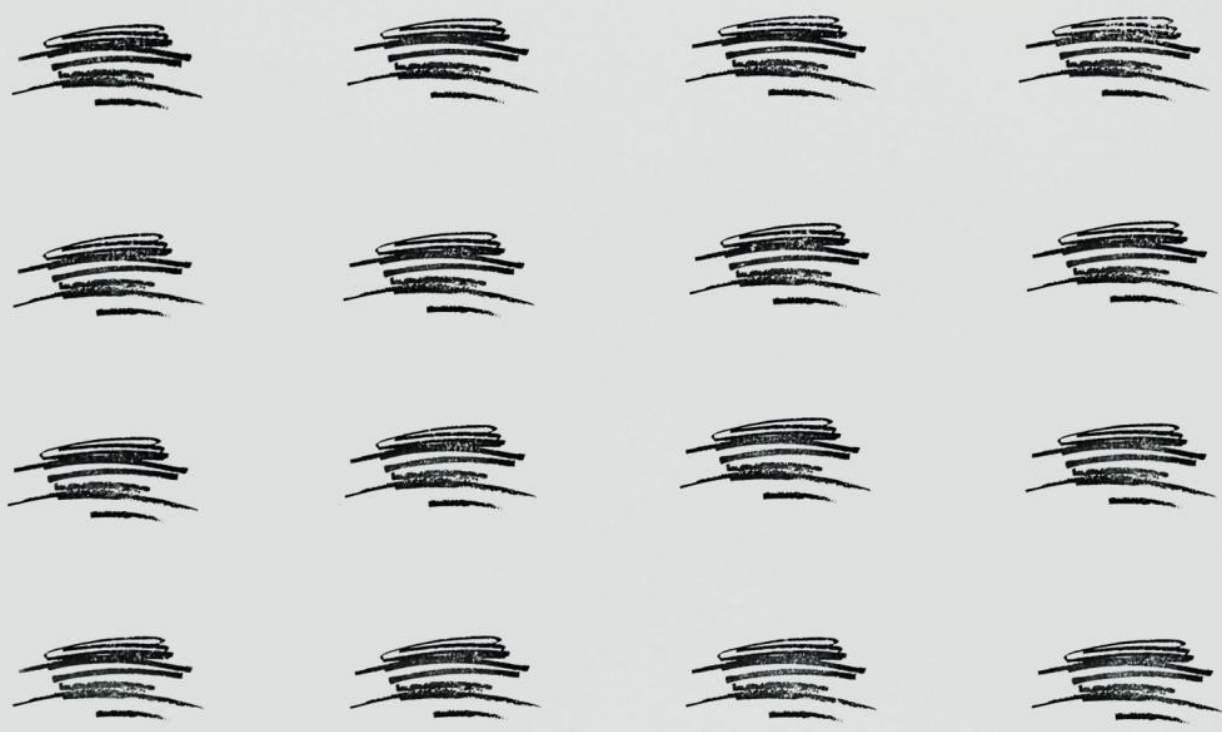

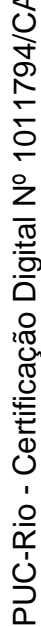

Figura 17 - Carimbos-rabiscos
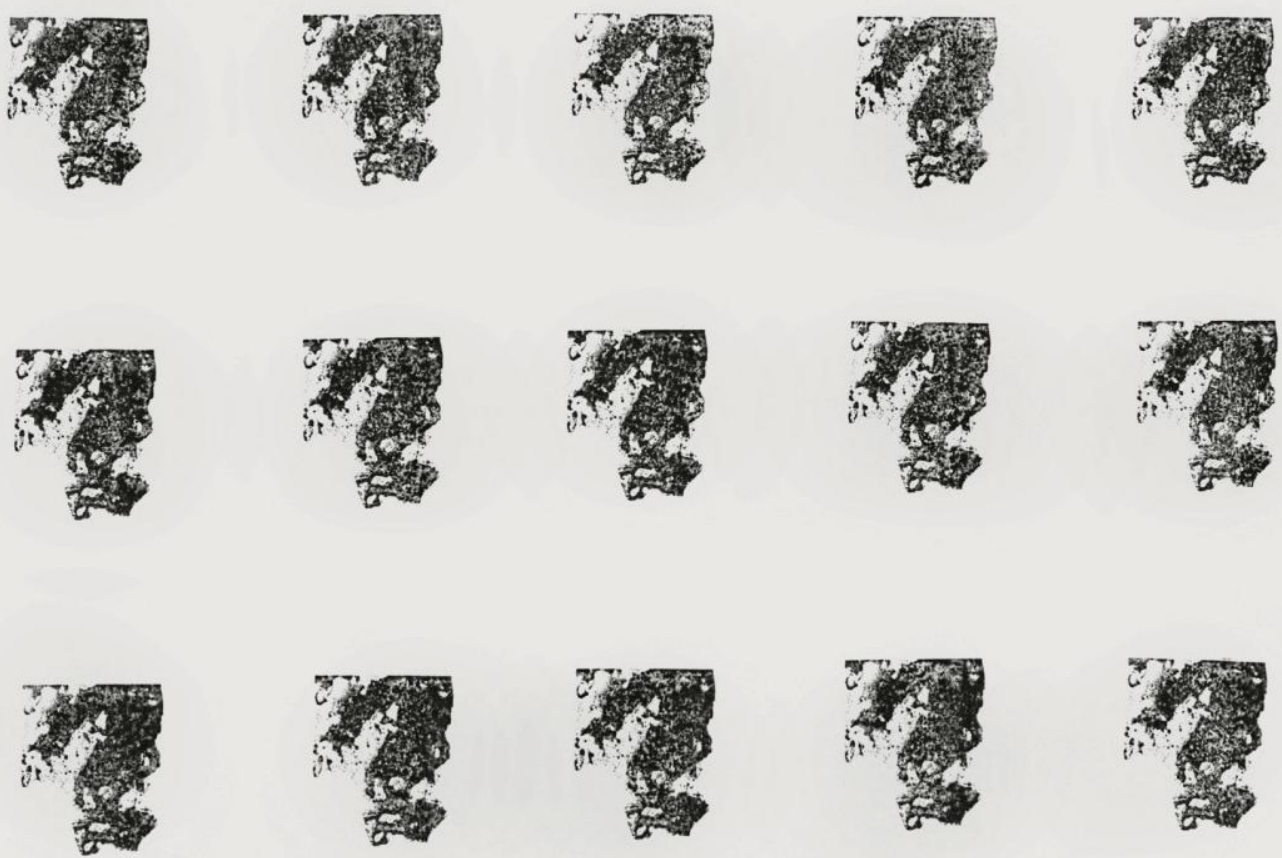

Figura 18 - Carimbos-manchas 

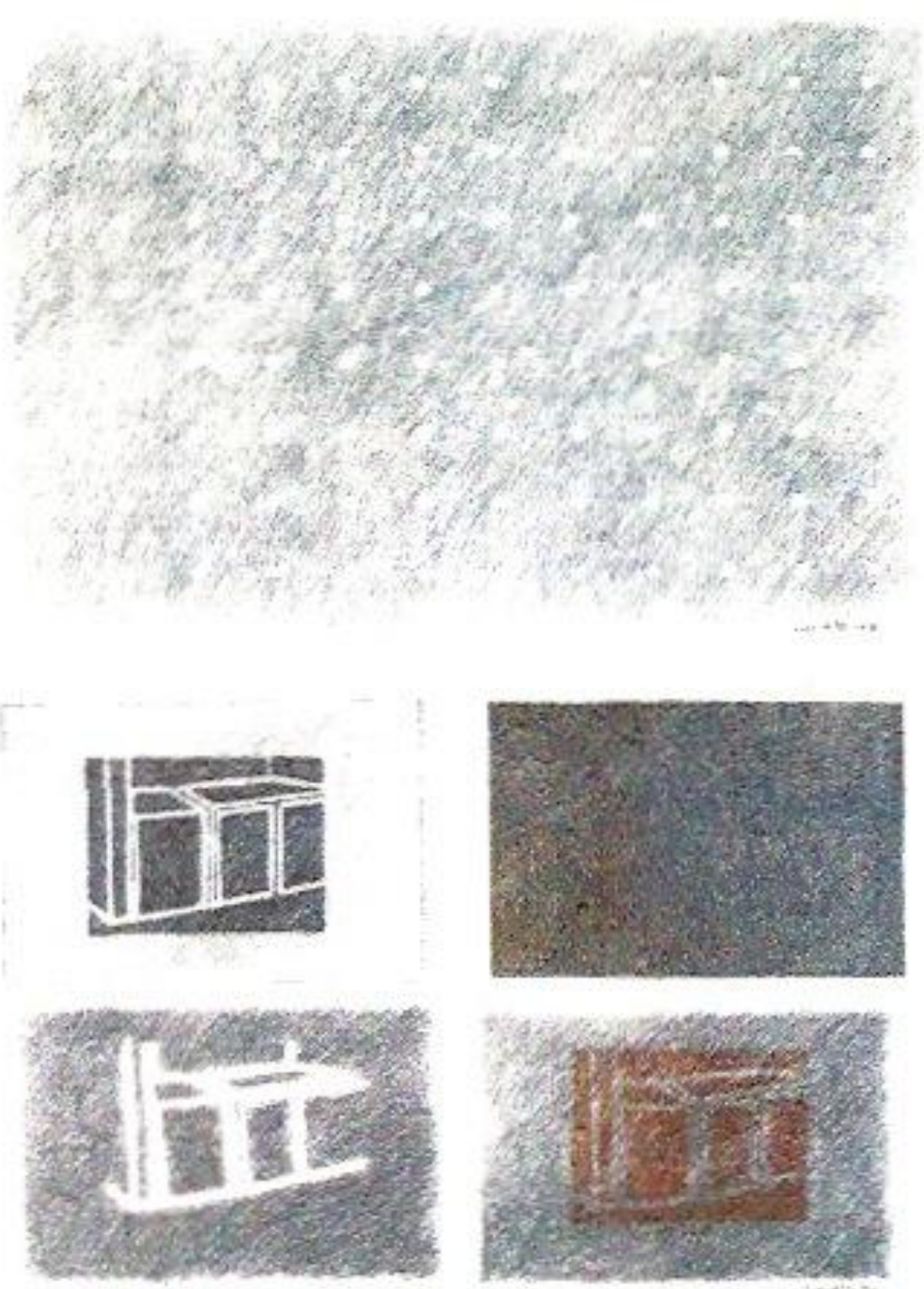

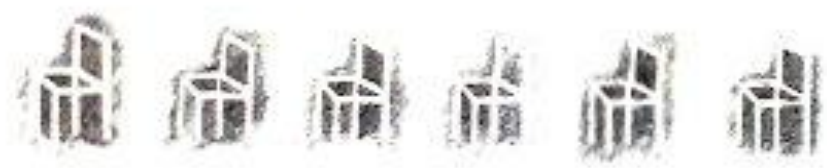
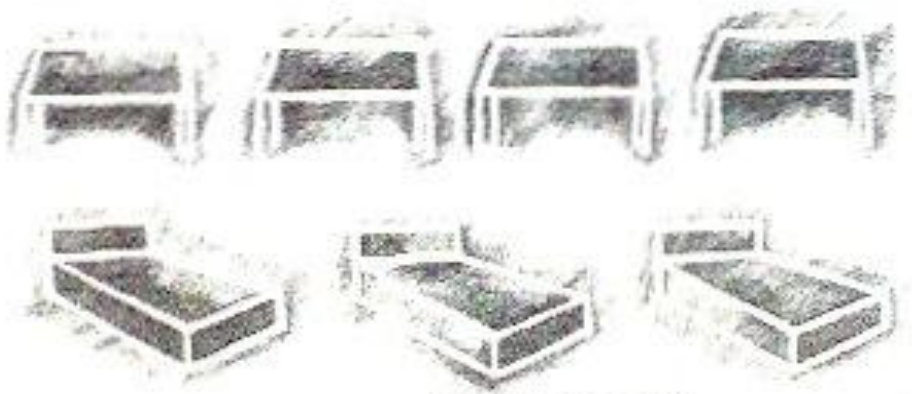

Figura 19 - Cartões familiares 


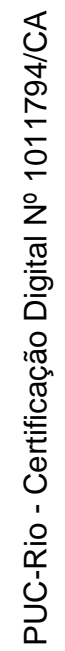

Figura 20 - Quasares 


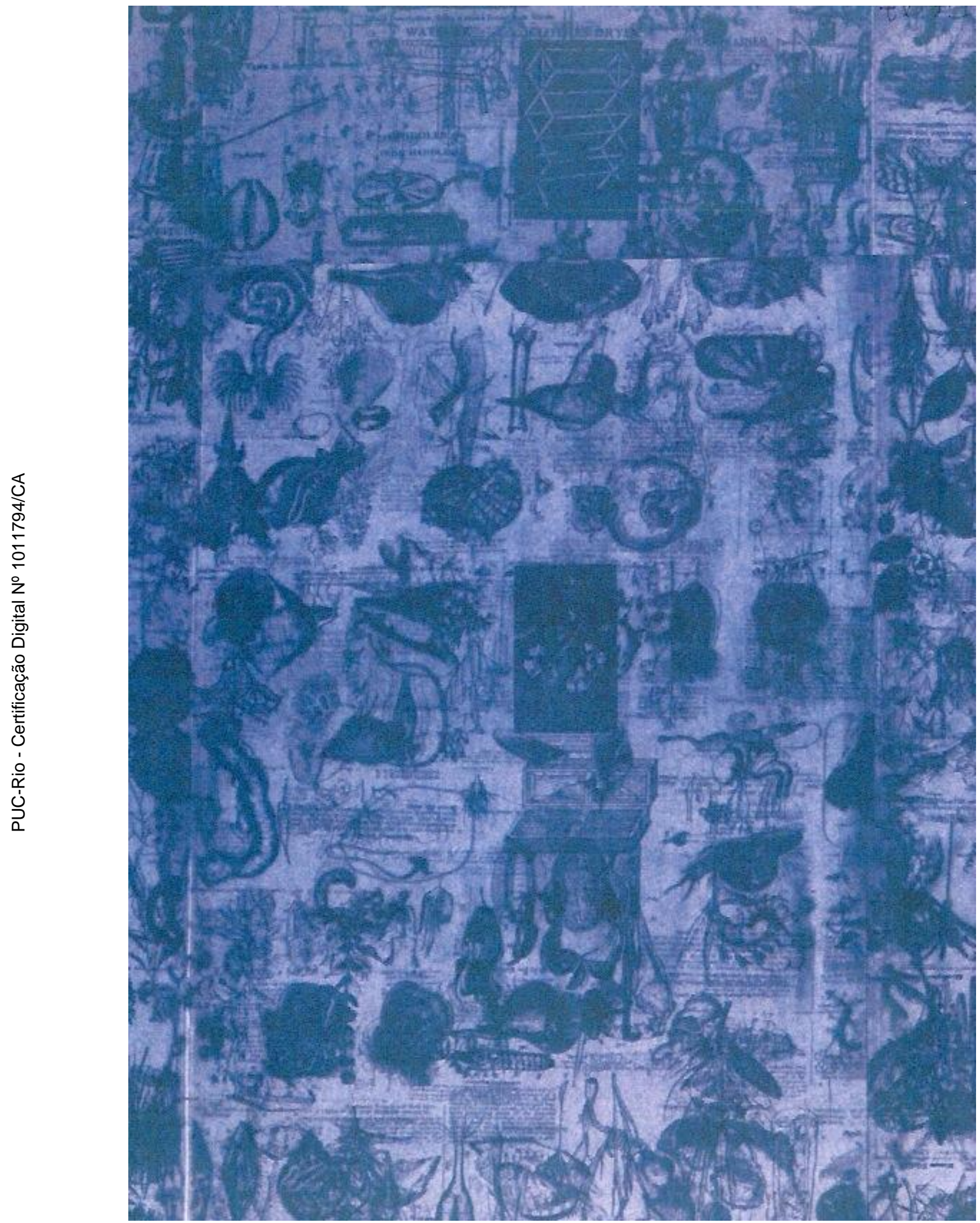

Figura 21 - Corpo de ideias 


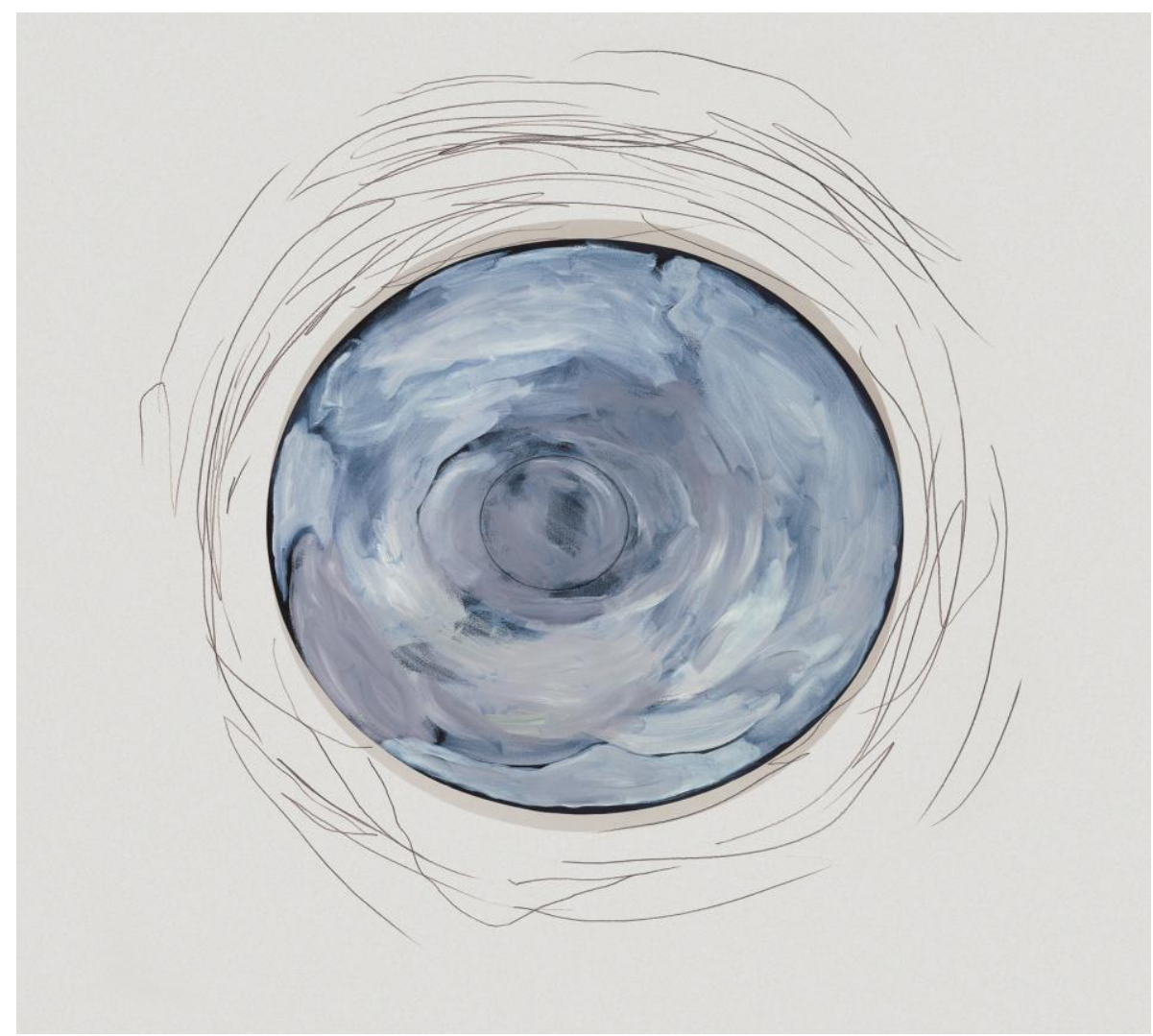

Figura 22 - Série Pintura-Desenho

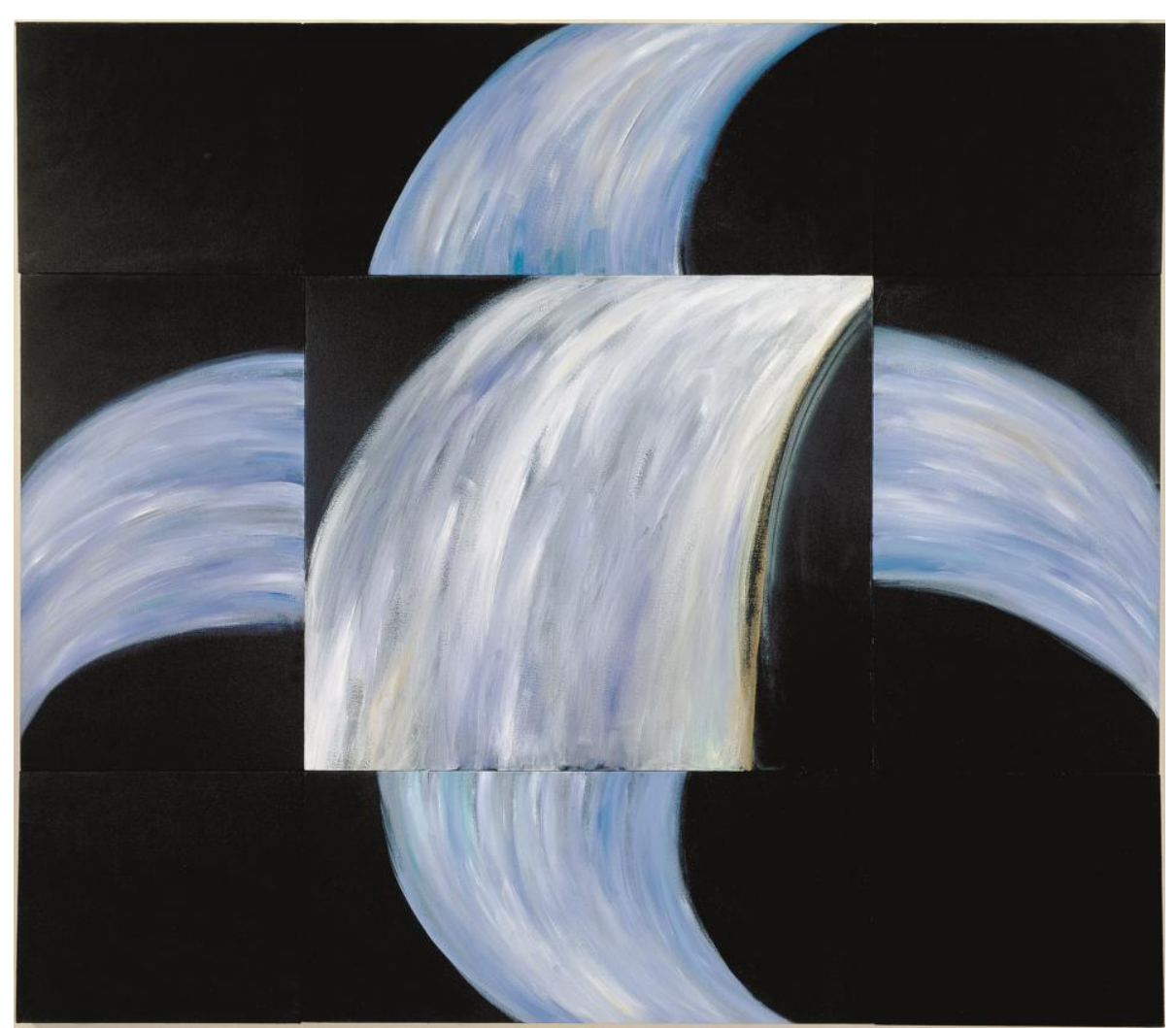

Figura 23 - Série Pintura-Desenho 


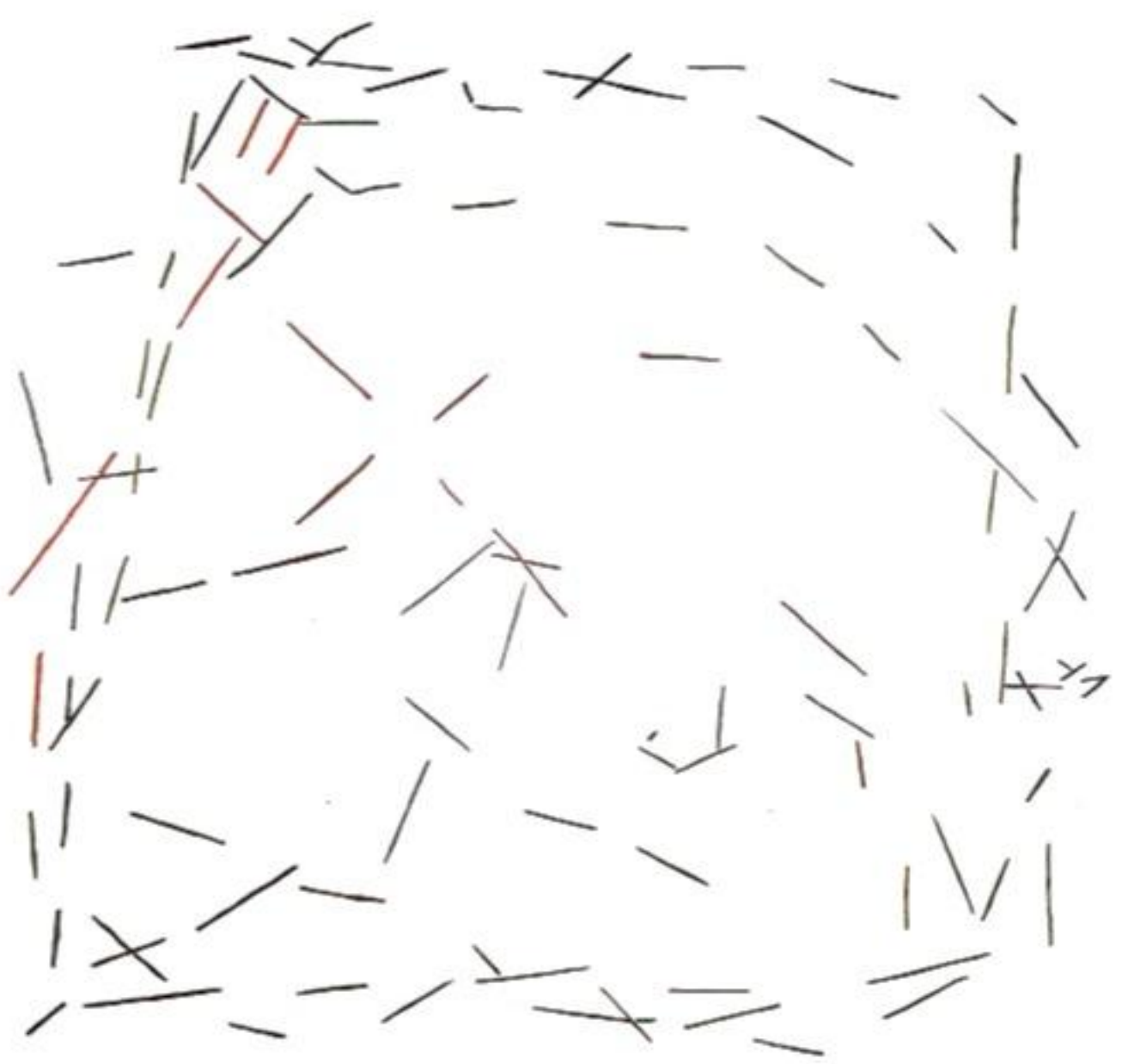

Figura 24 - Linha-objeto 


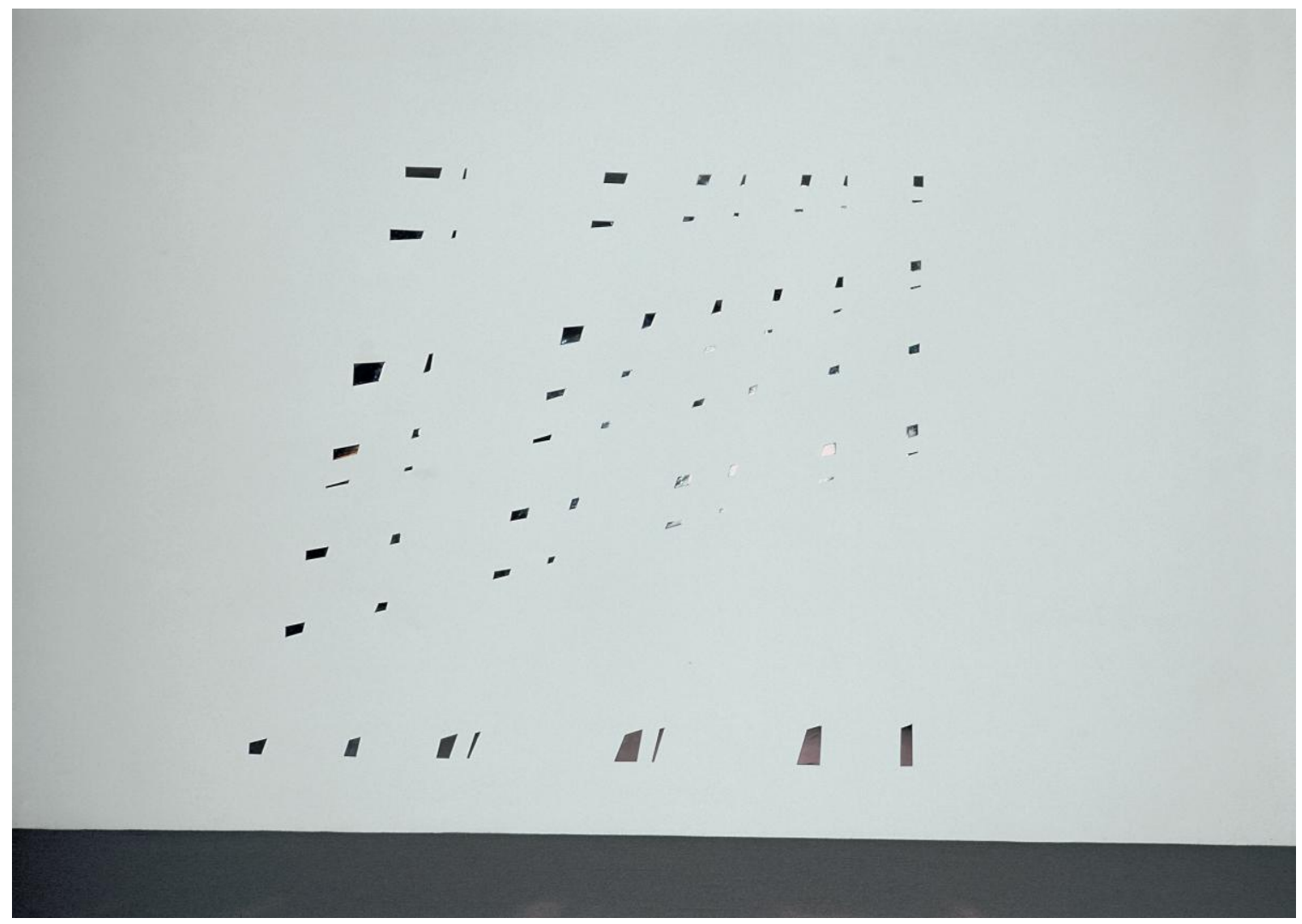

Figura 25 - Expansivo

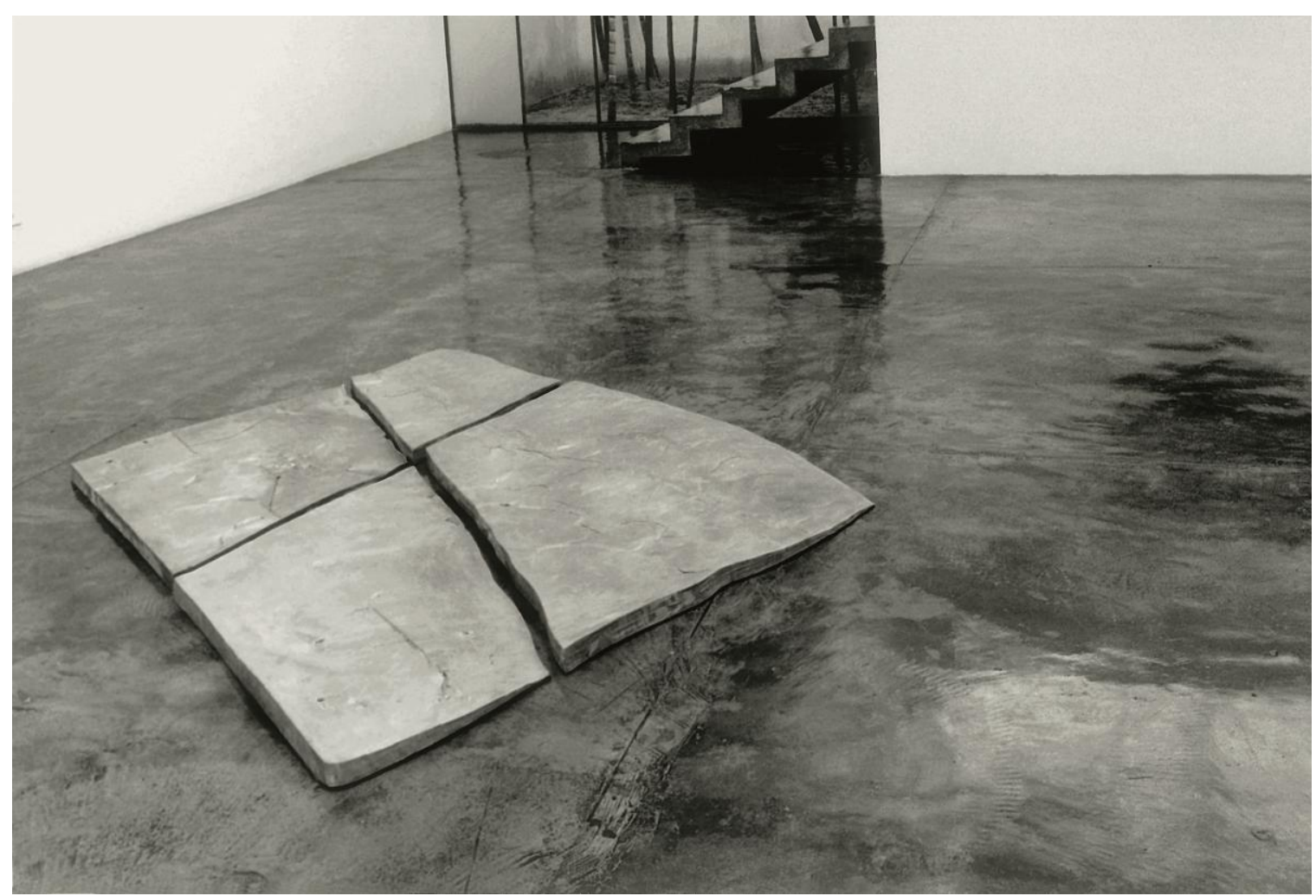

Figura 26 - Praia 


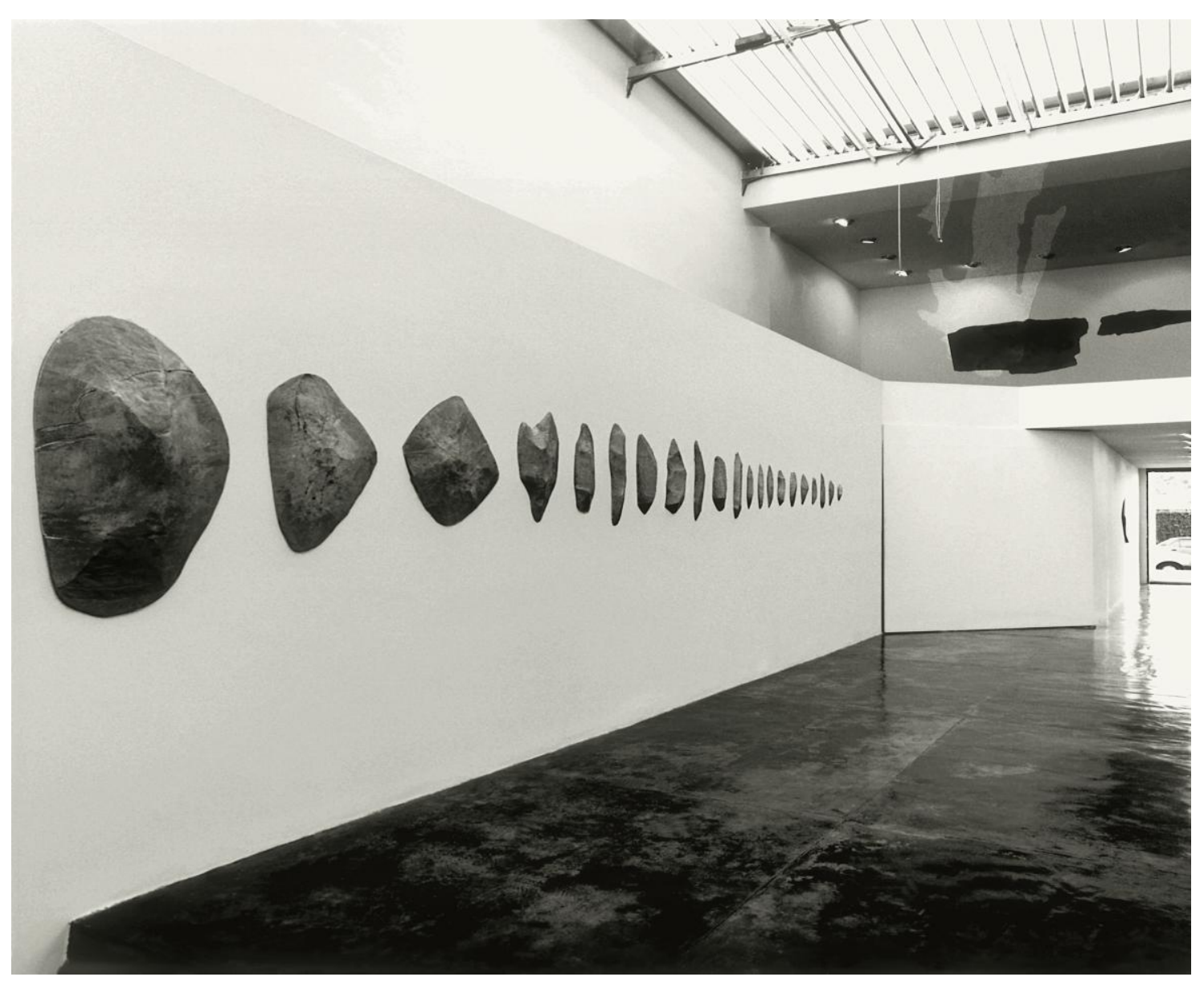

Figura 27 - Trem

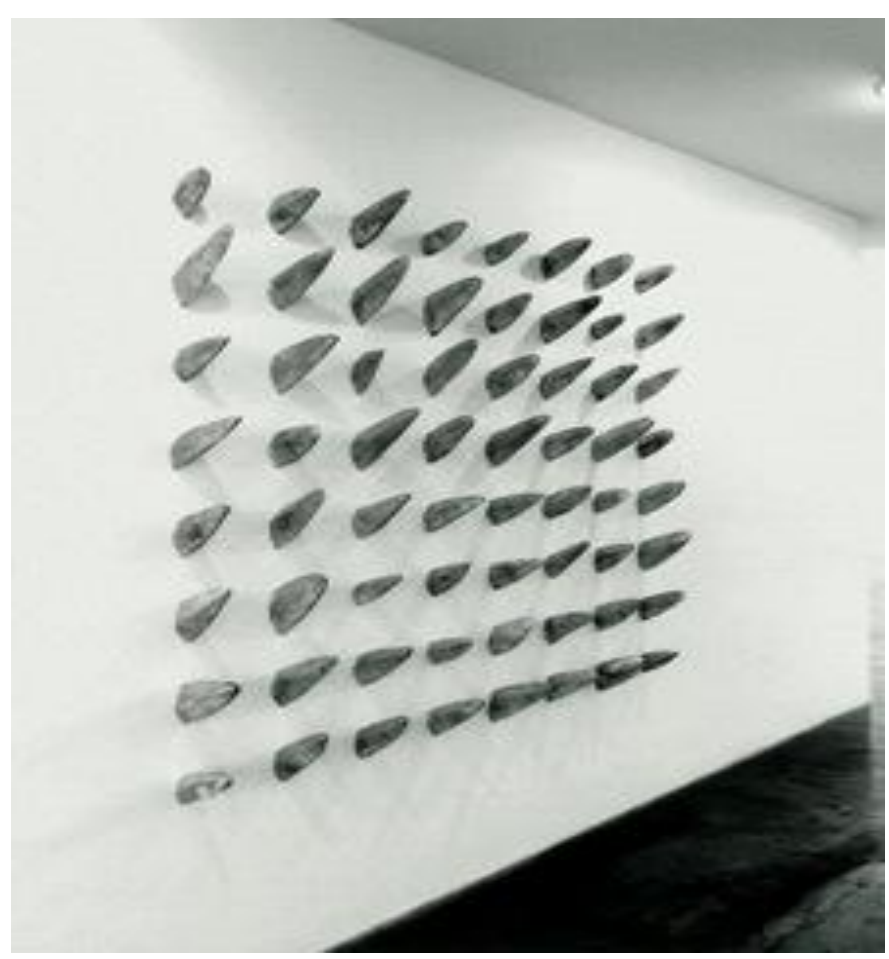

Figura 28 - Peixes 


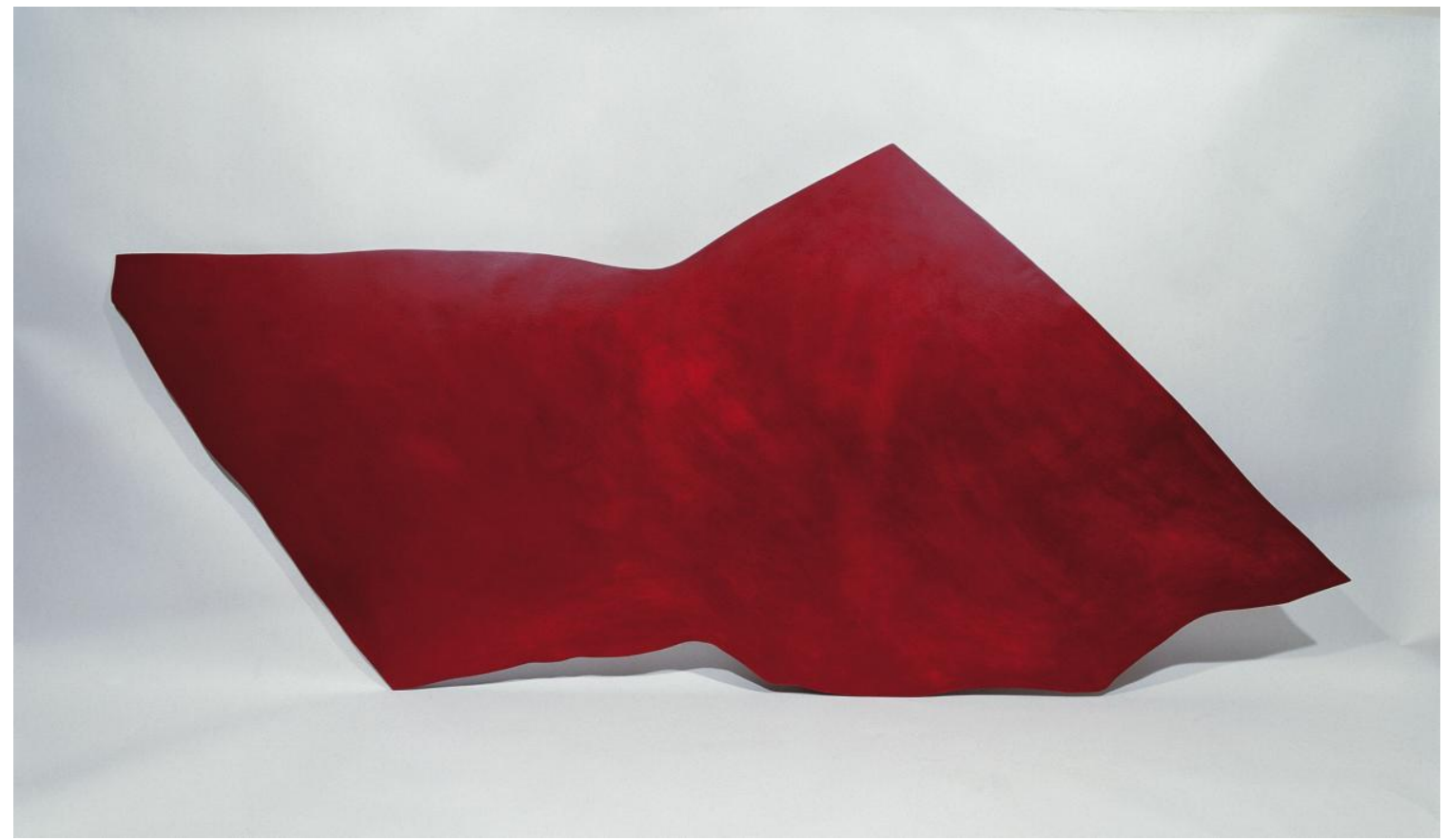

Figura 29 - Parte vermelha

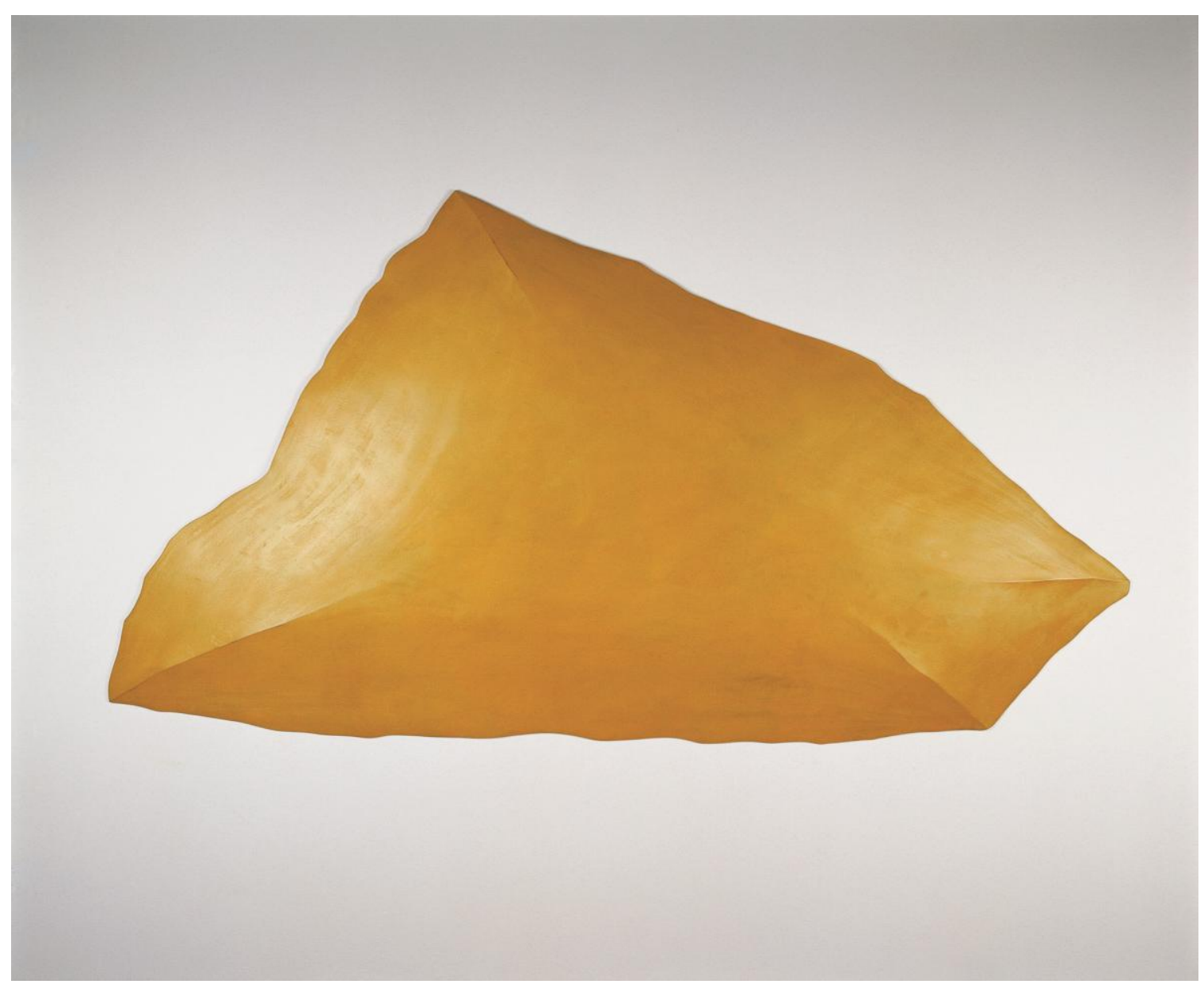

Figura 30 - Parte amarela 


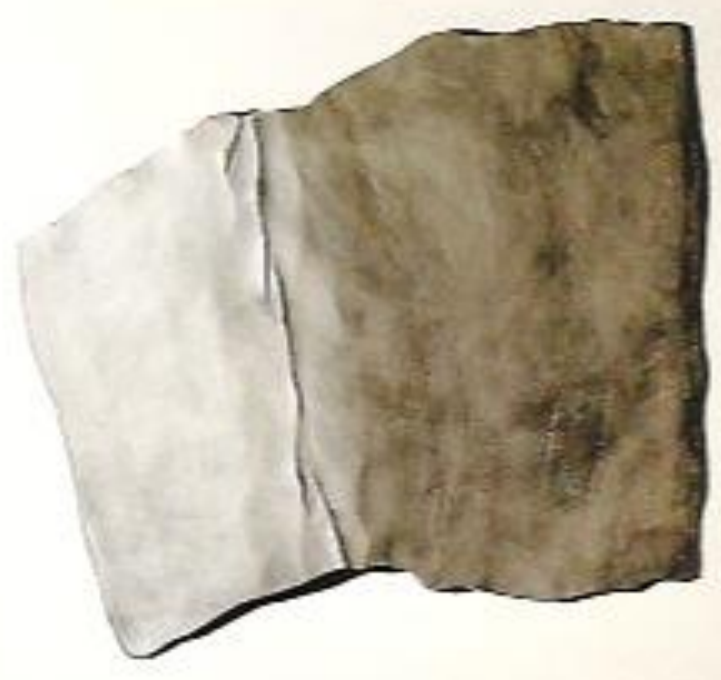

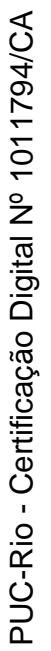

Figura 31 - Parte prata

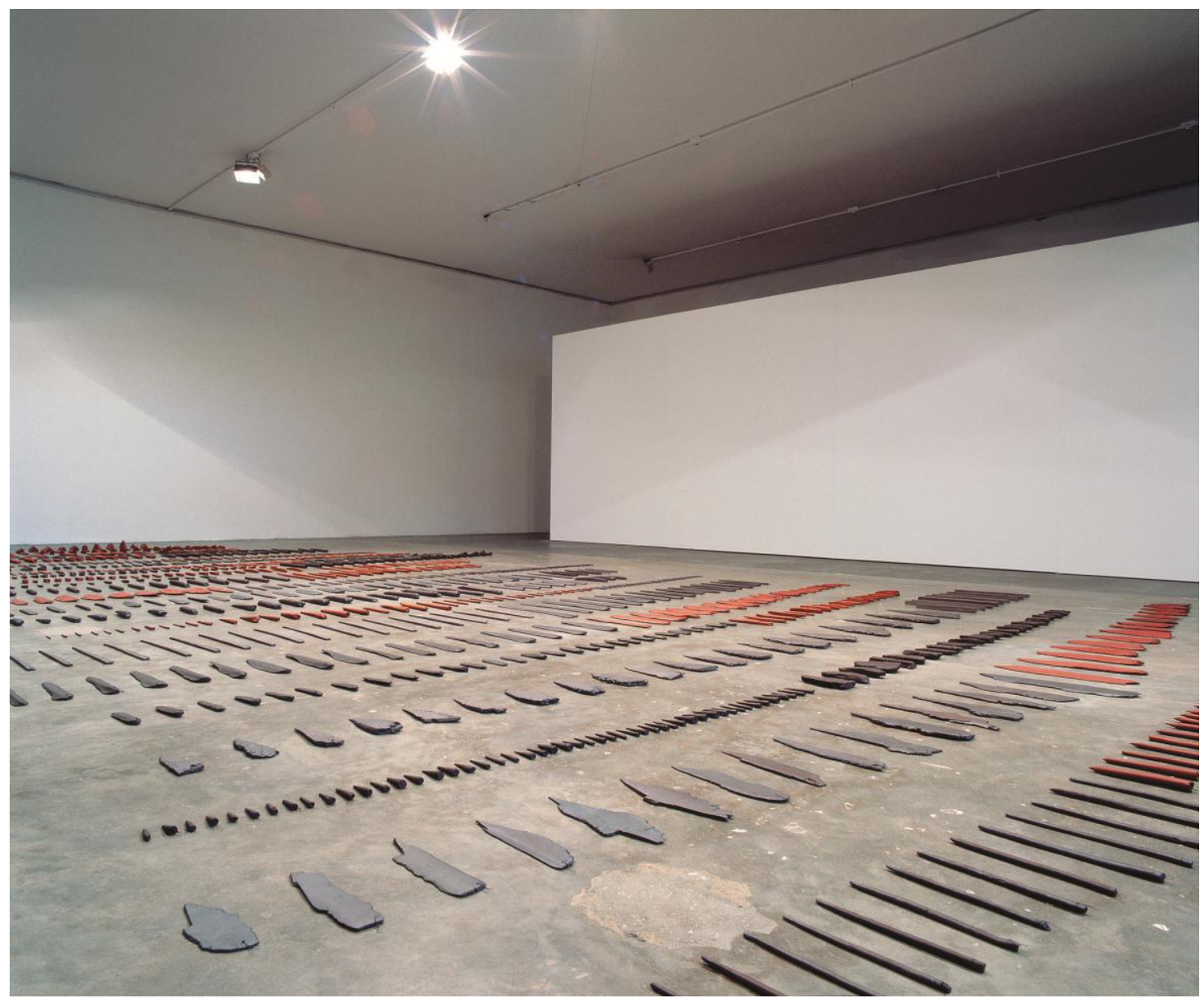

Figura 32 - Facas 


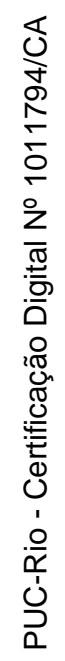

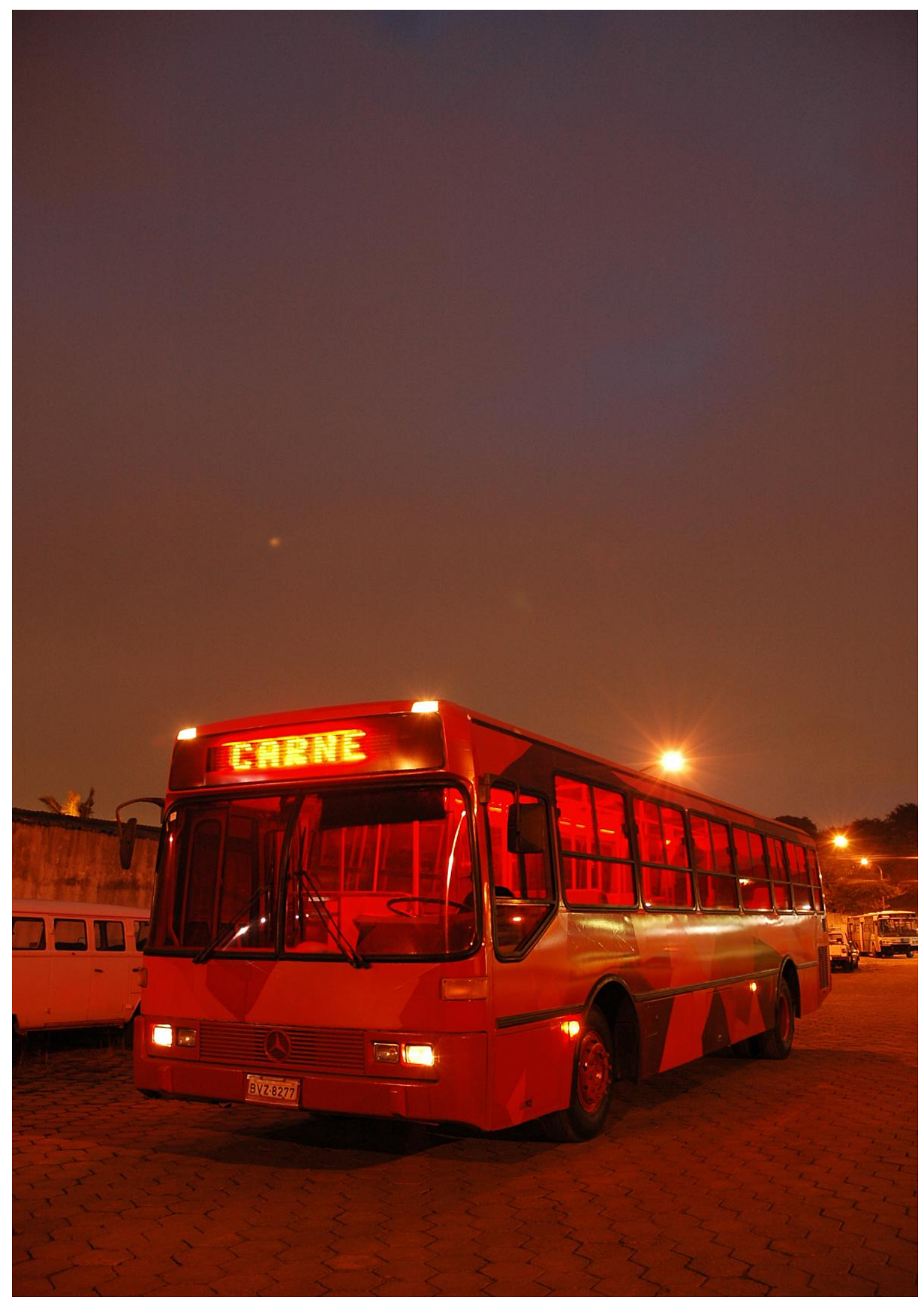

Figura 33 - Carne 


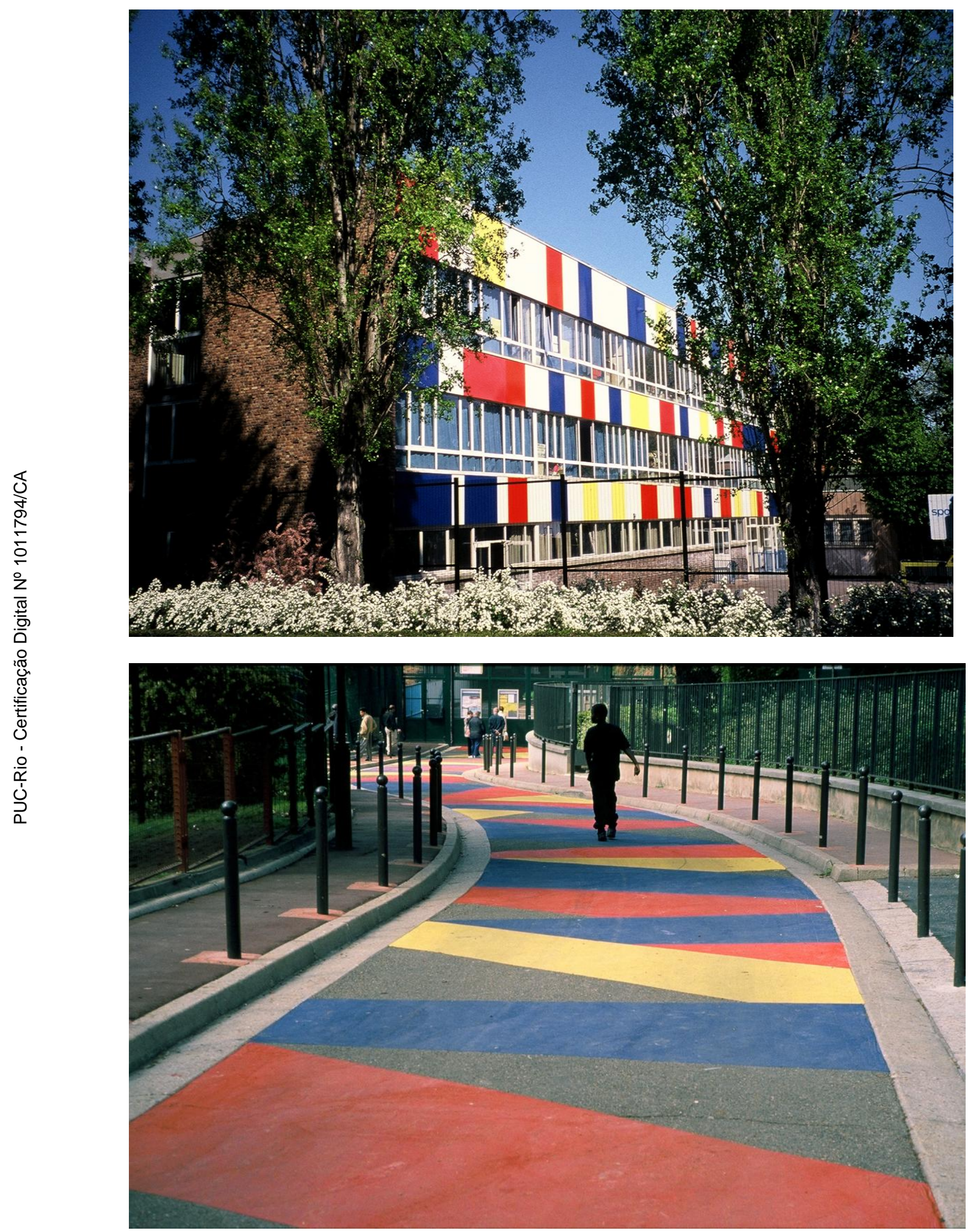

Figura 34 - bleu, jaune, rouge, rouge 


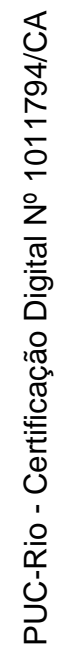

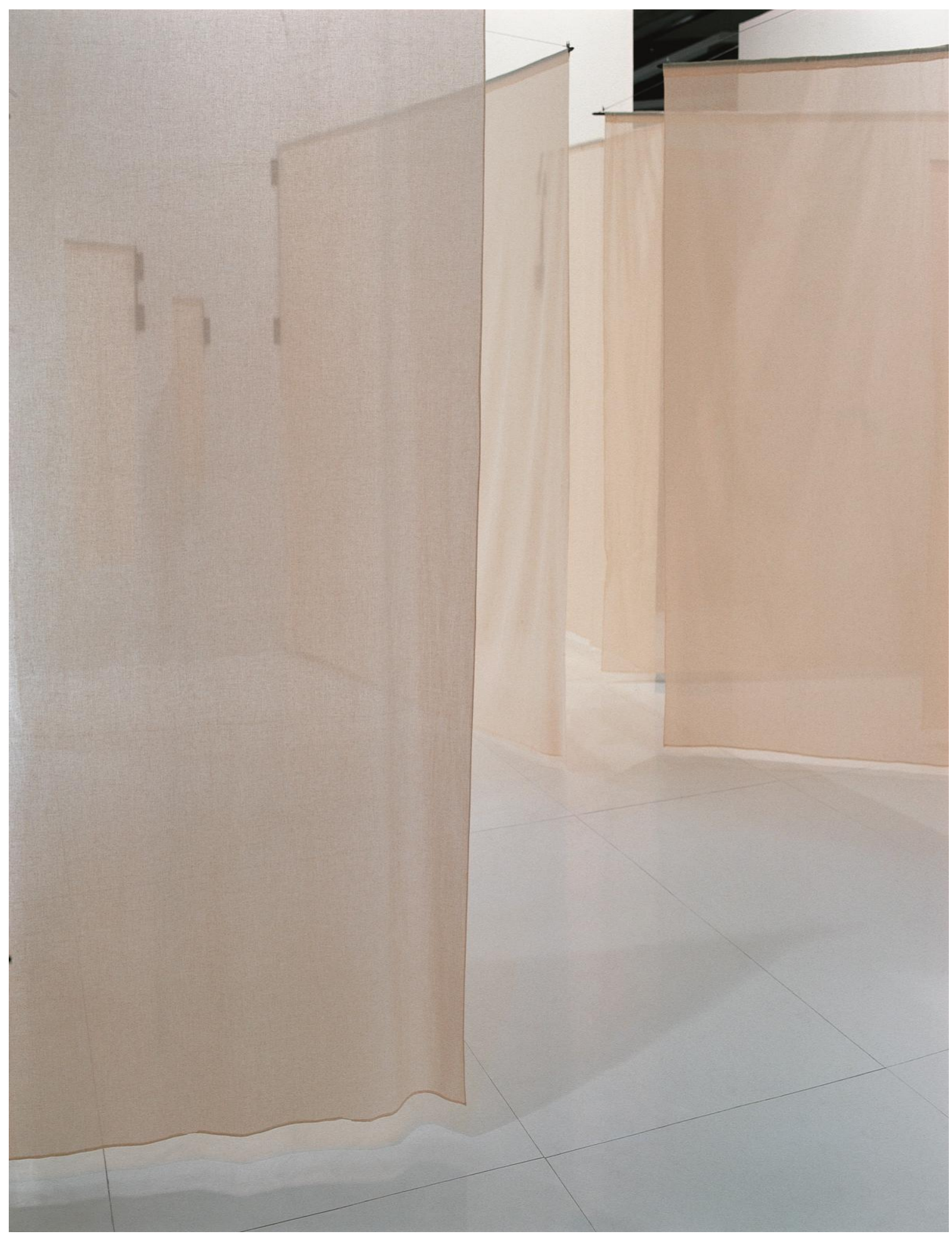

Figura 35 - 28 Operações 


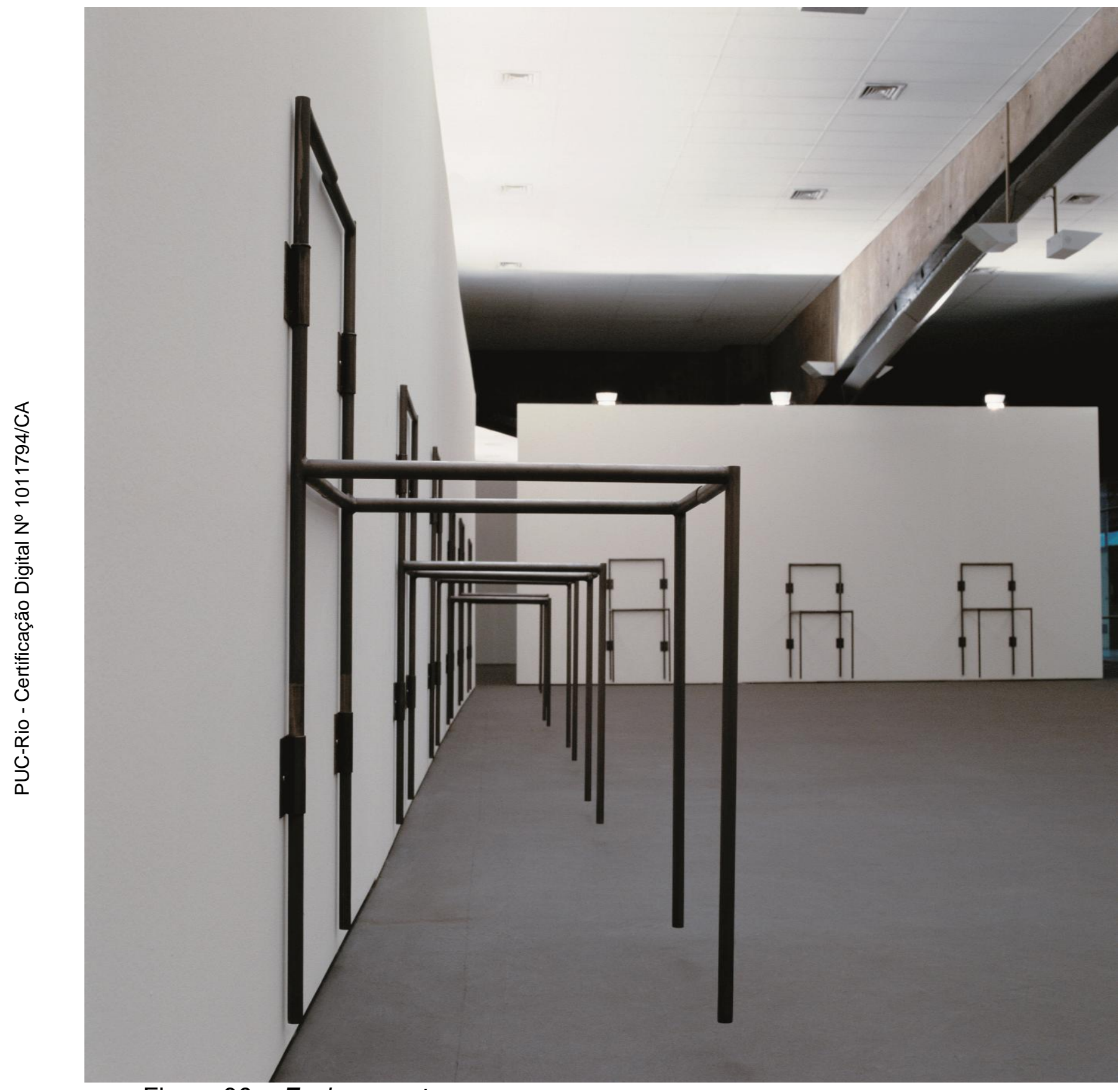

Figura 36 - Feche a porta 


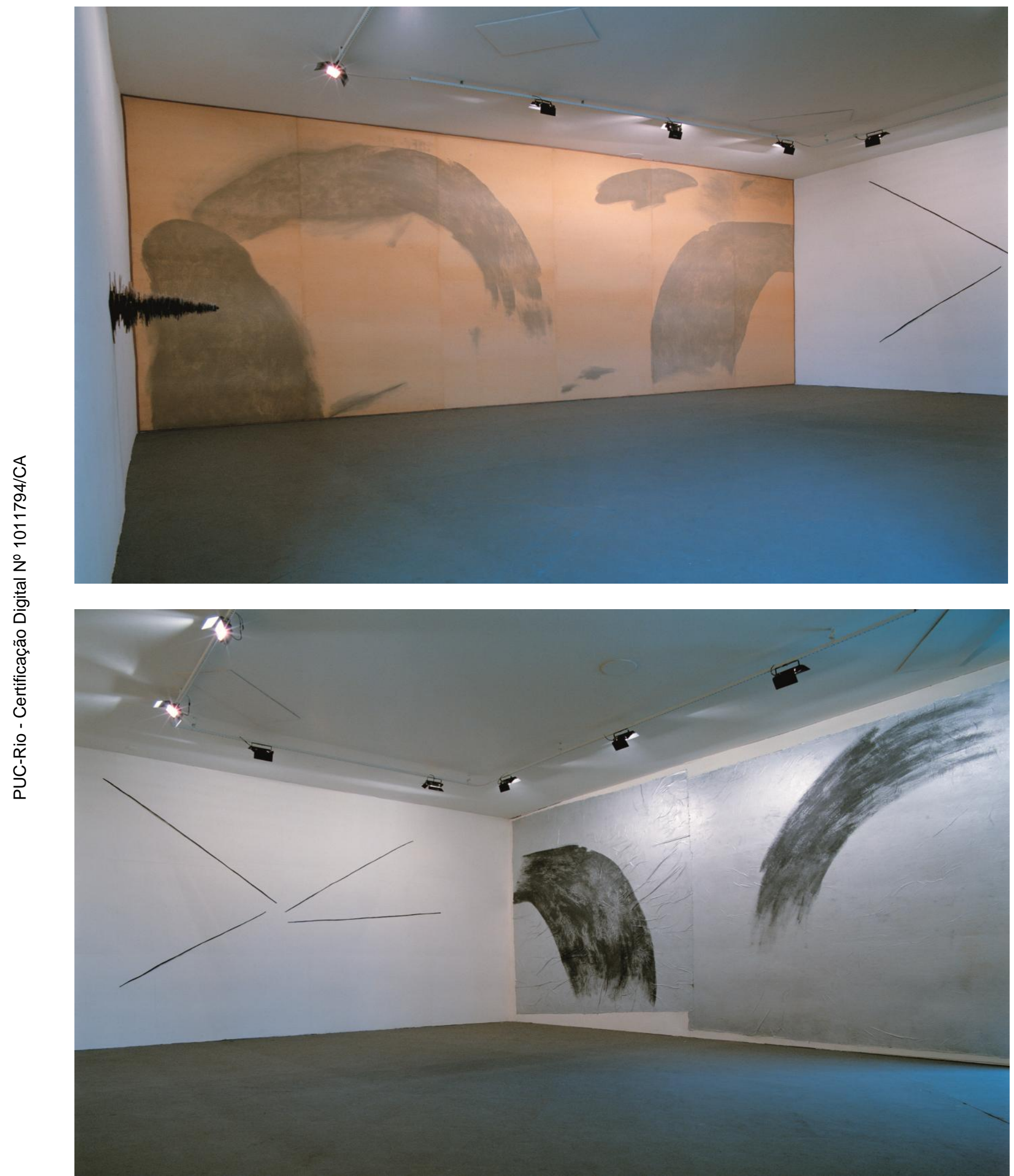

Figura 37 - Instalação na $20^{\text {a }}$ Bienal Internacional de São Paulo 


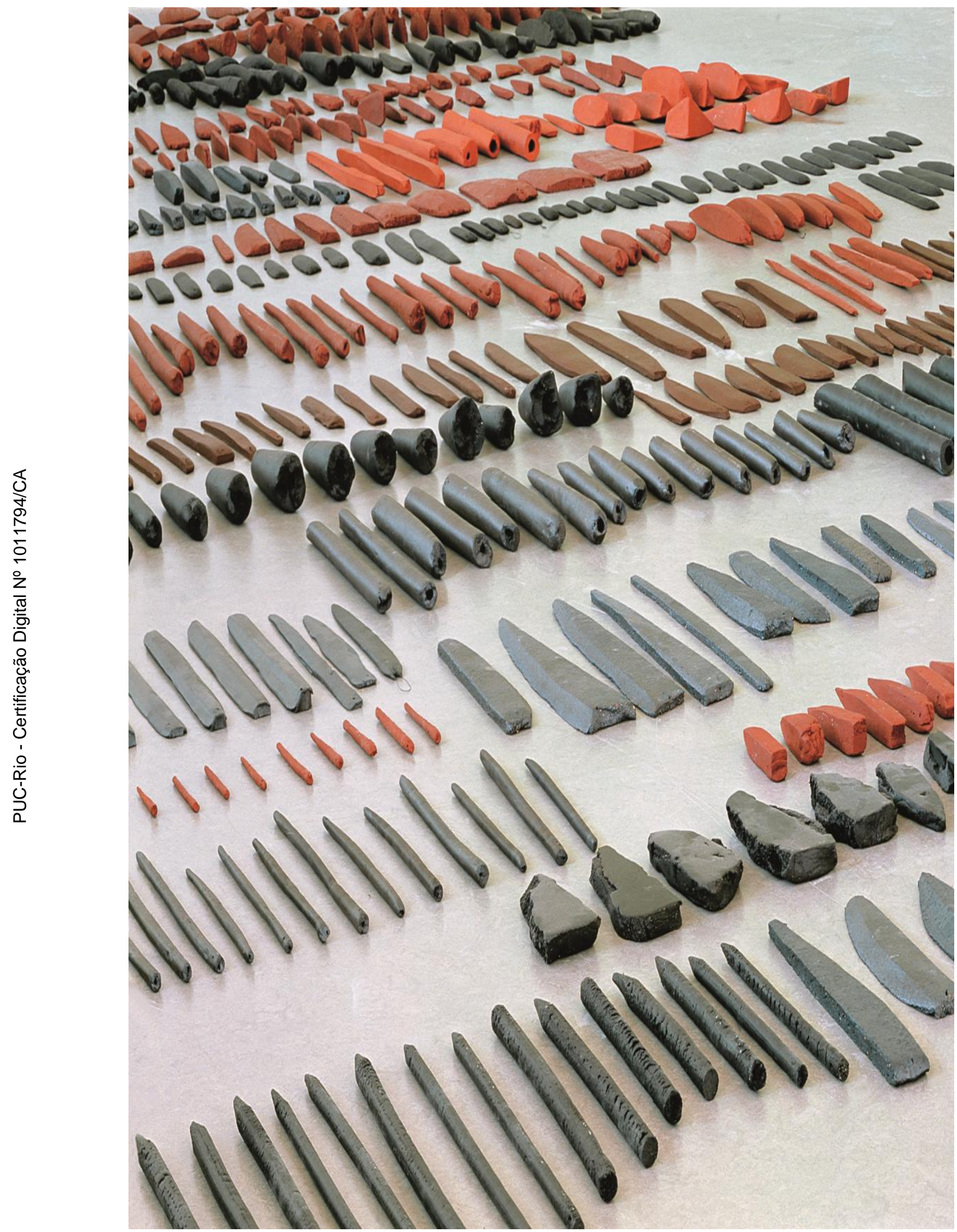

Figura 38 - Facas 


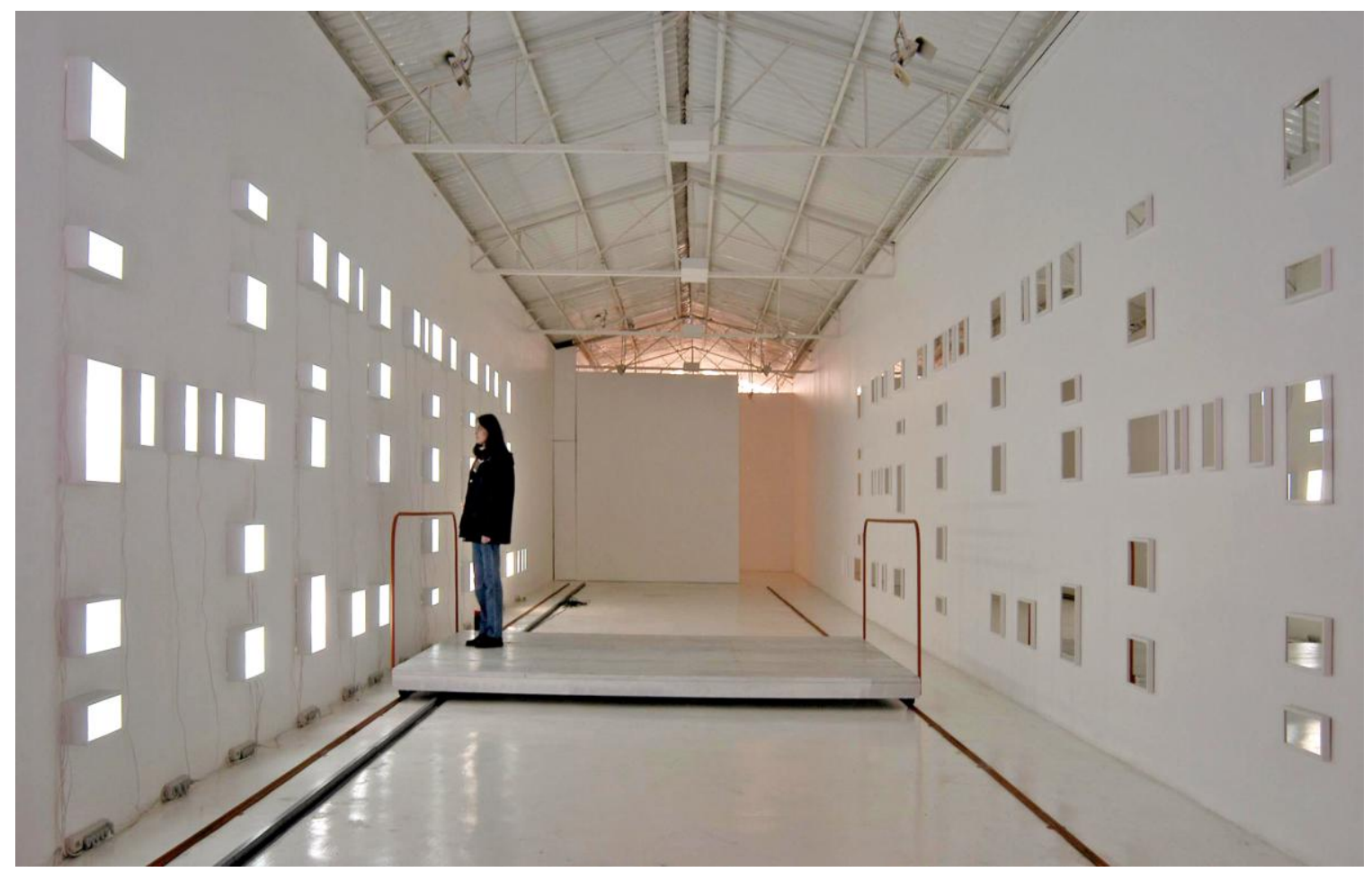

Figura 39 - Hotel Balsa

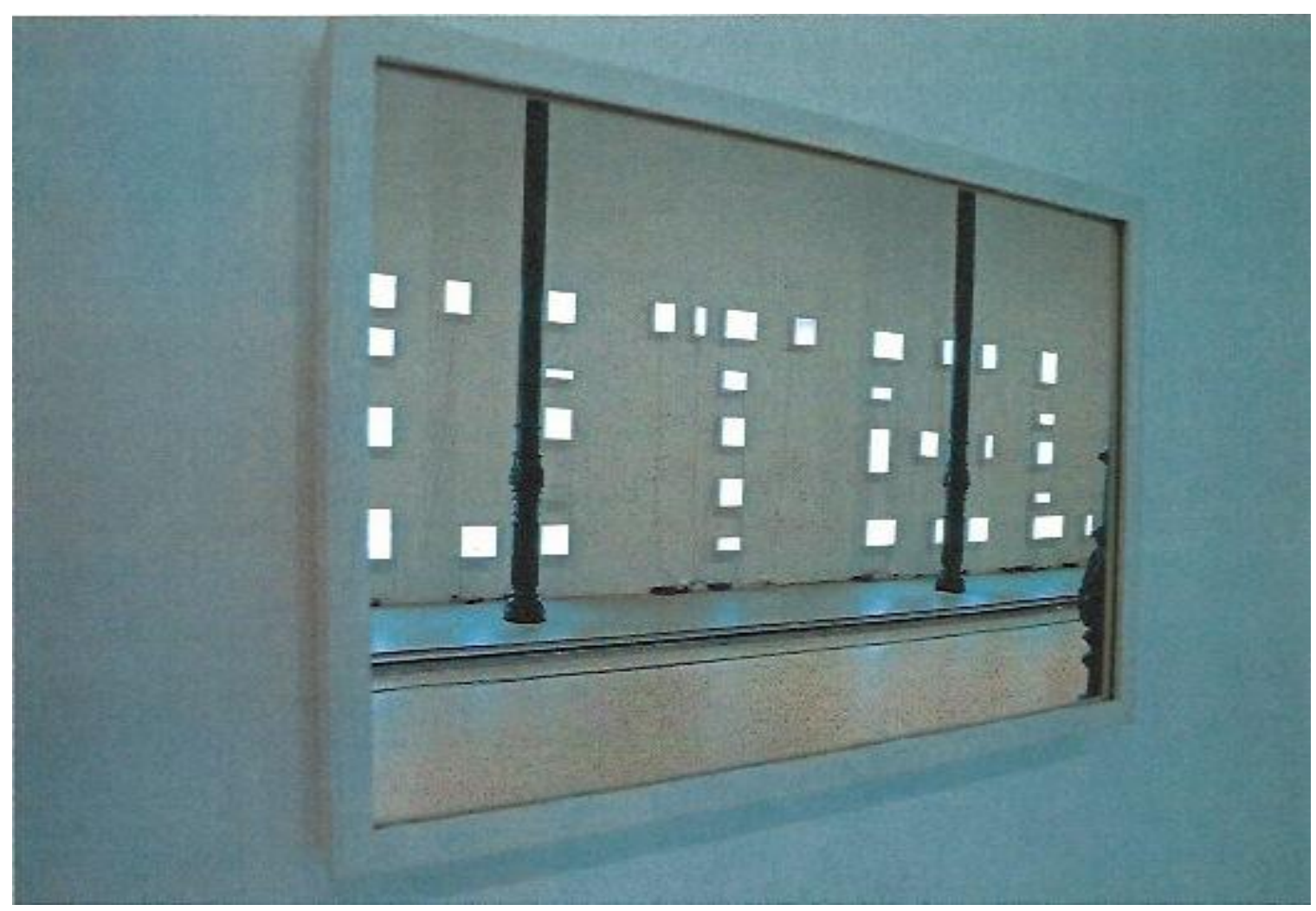

Figura 40 - Hotel Balsa 


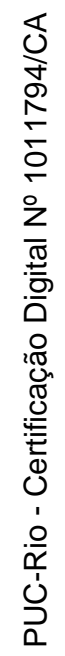
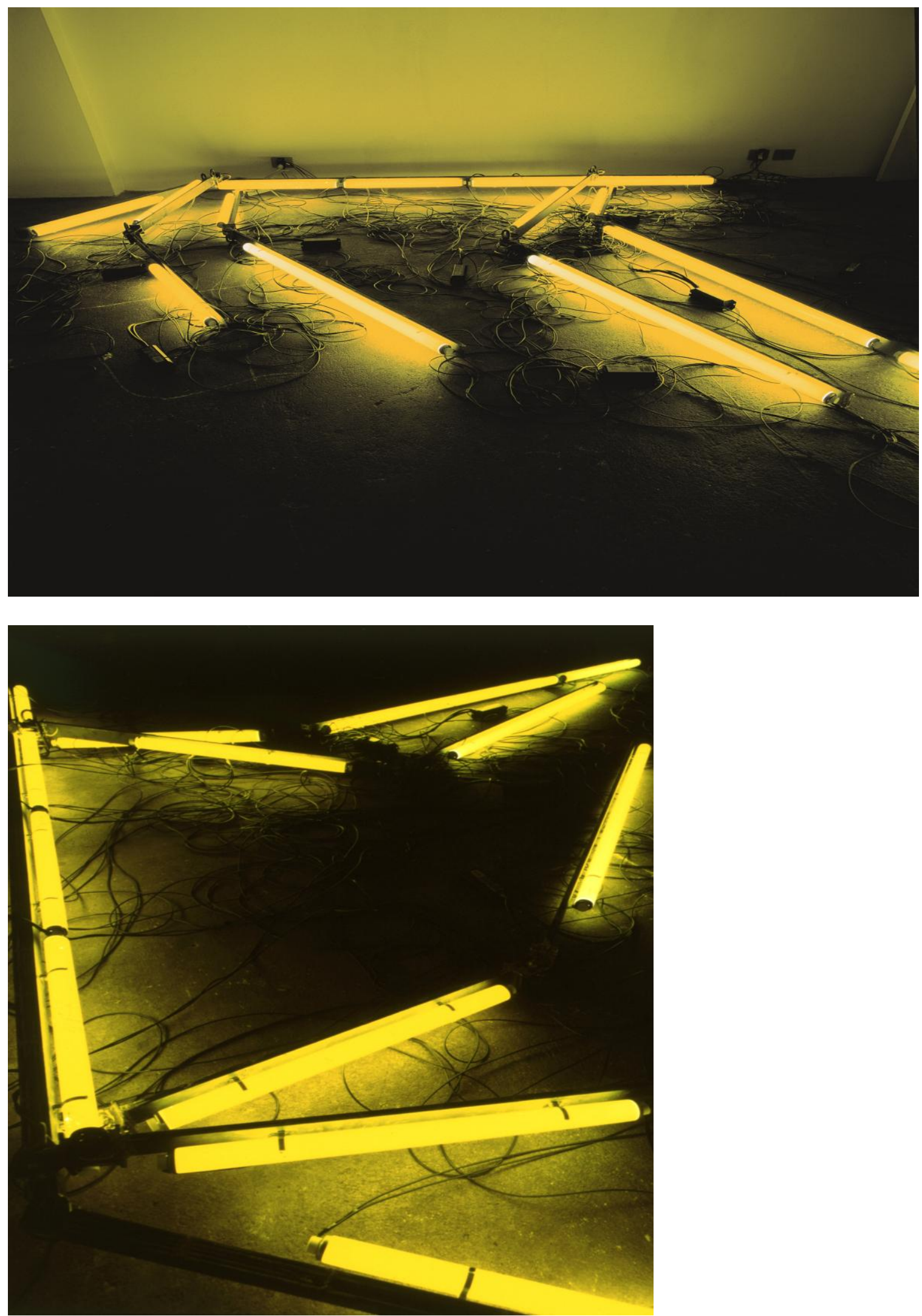

Figura 41 - Comedor de Luz 


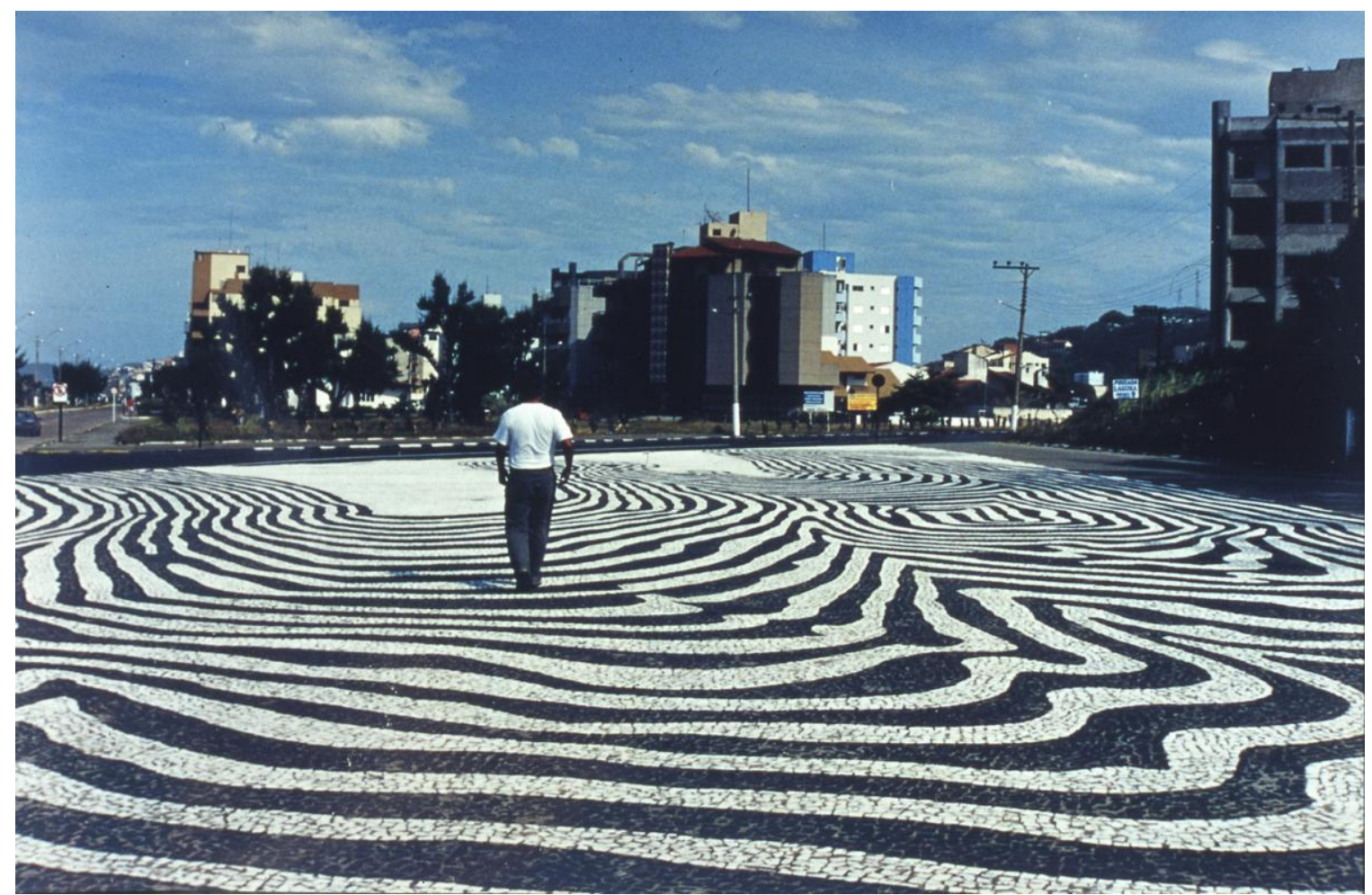

Figura 42 - Fonte/Foz
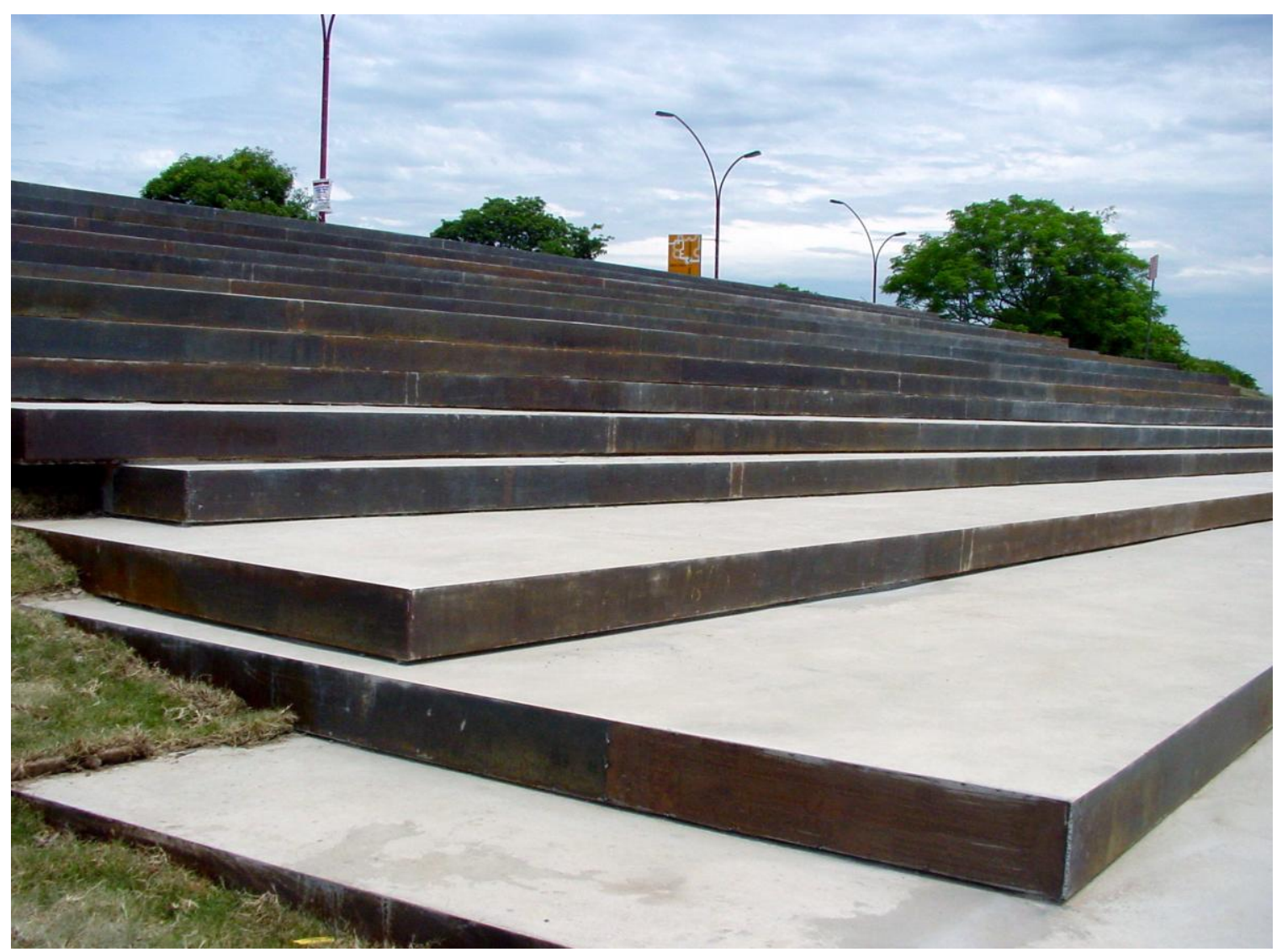

Figura 43 - Cascata 


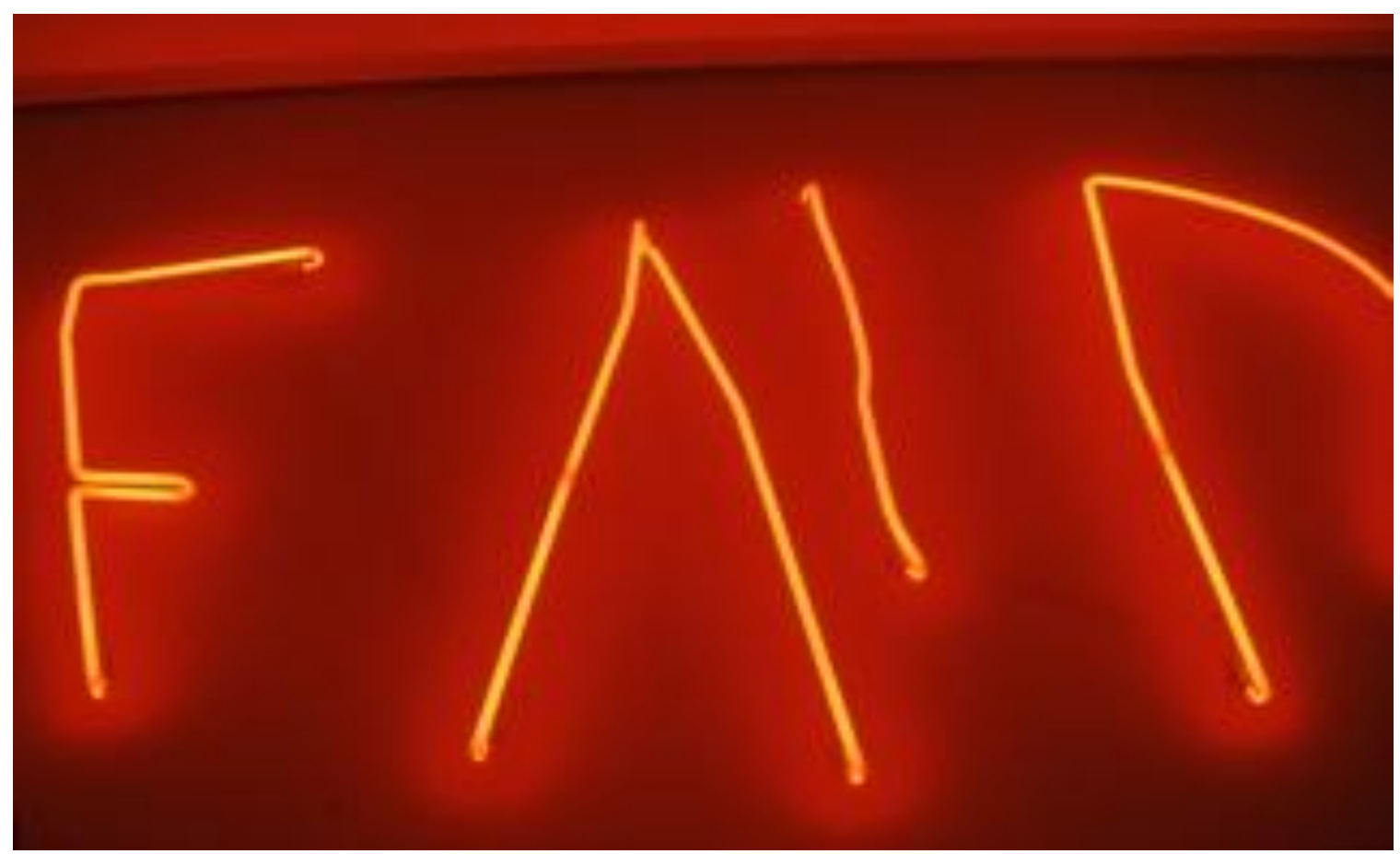

Figura 44 - Us Cara Fugiu Correndo

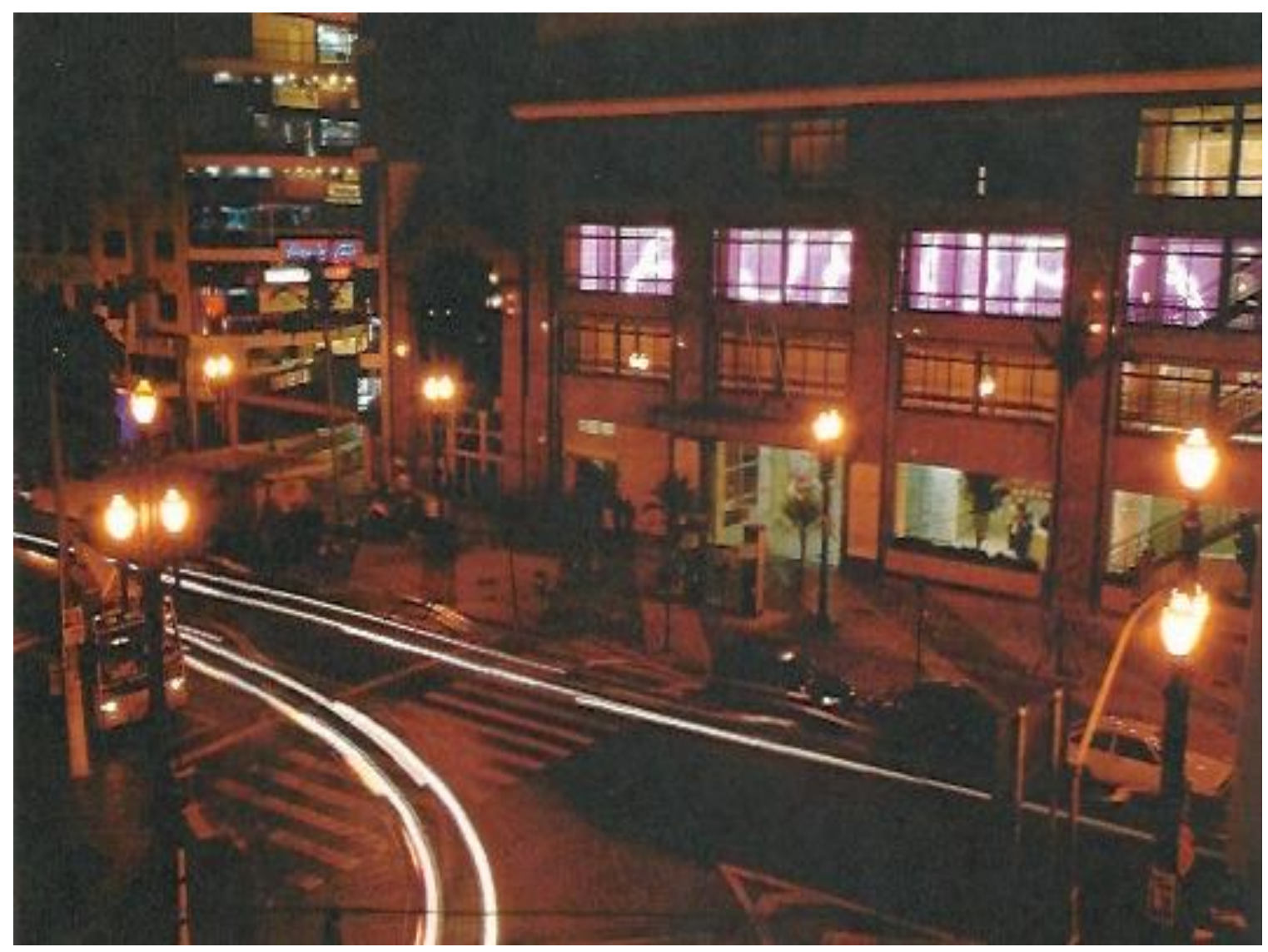

Figura 45 - Aurora 


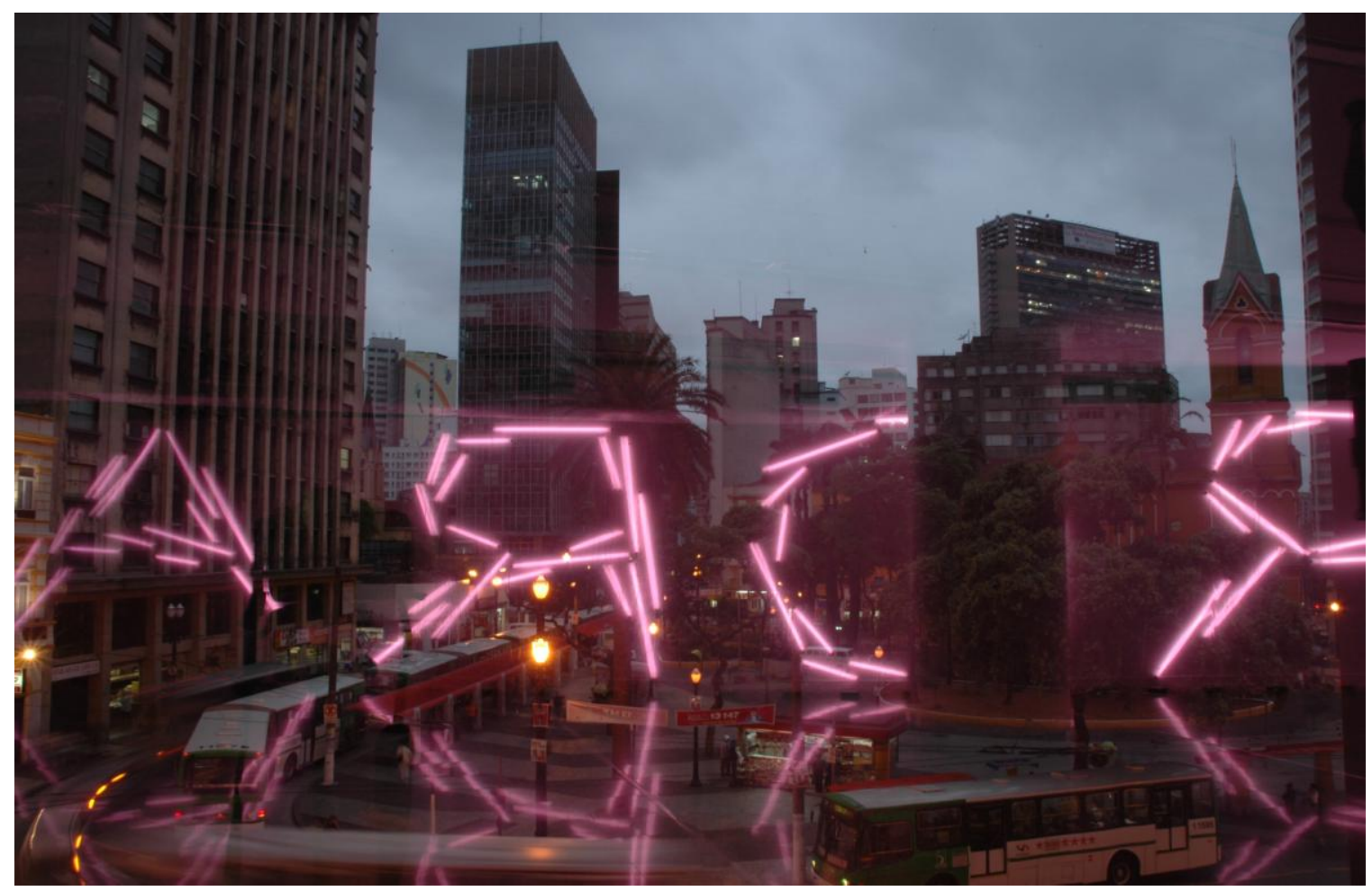

Figura 46 - Aurora [vista do Largo do Paissandu]

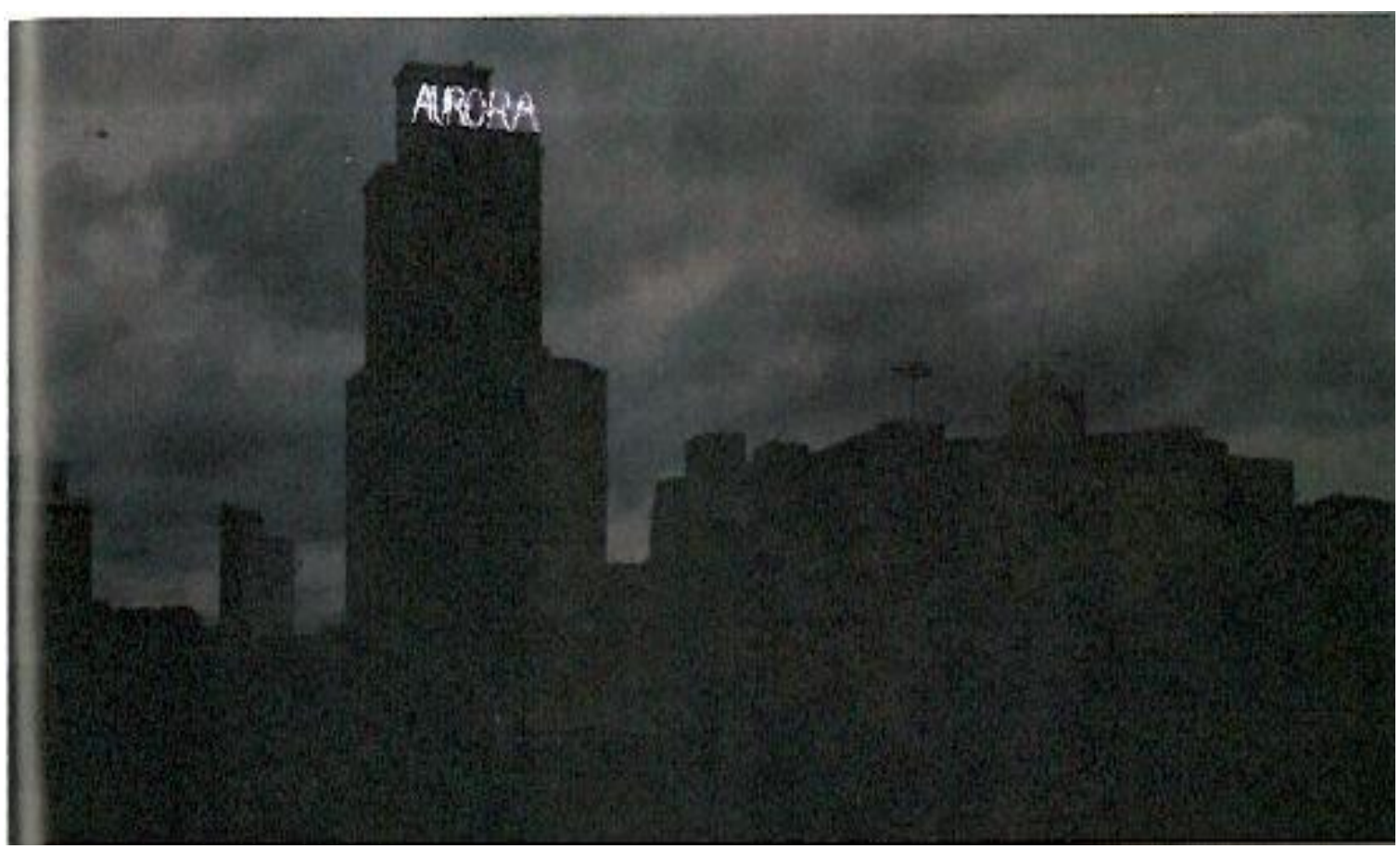

Figura 47 - Aurora, Bienal de Moscou 


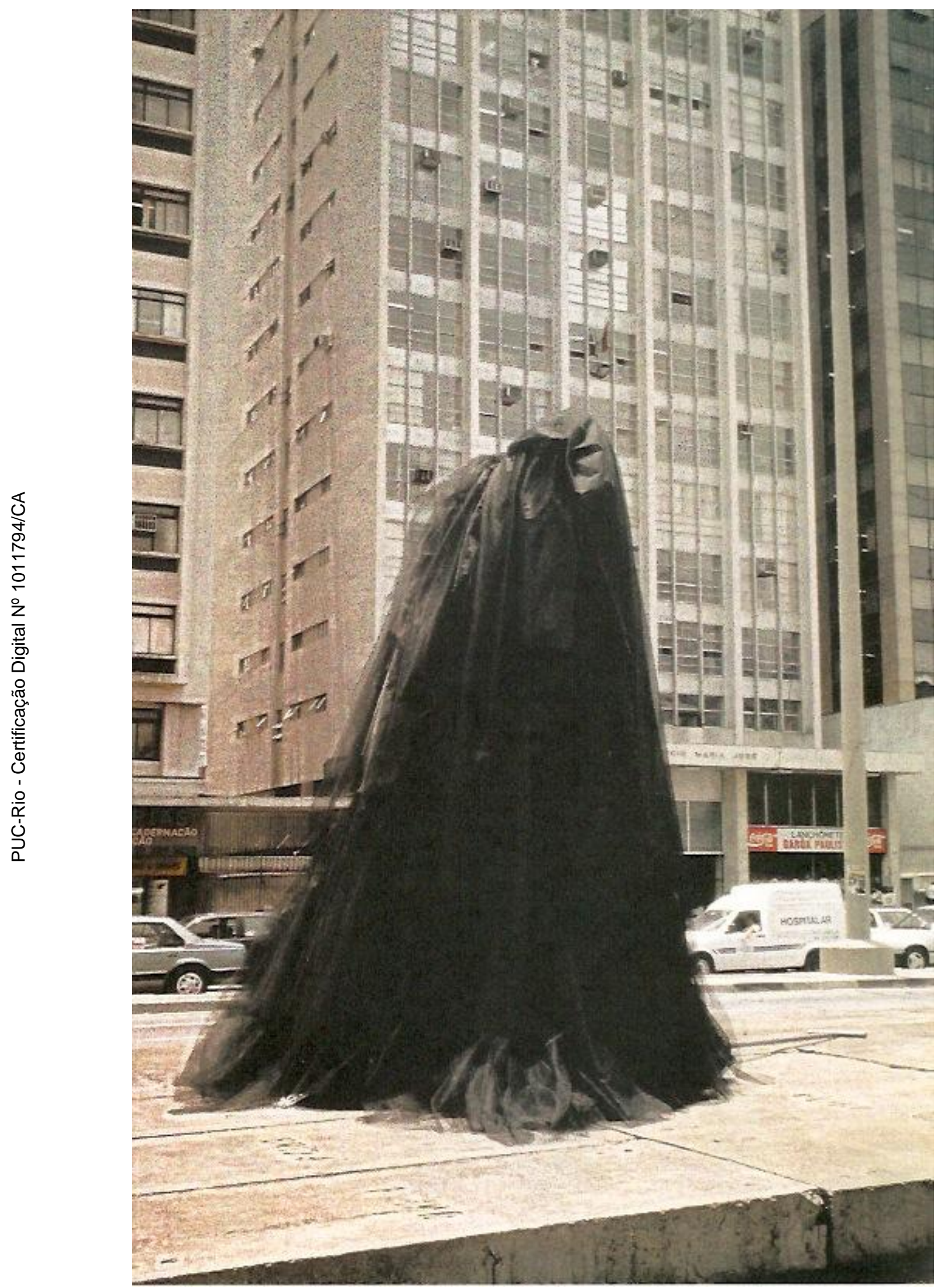

Figura 48 - A Negra 


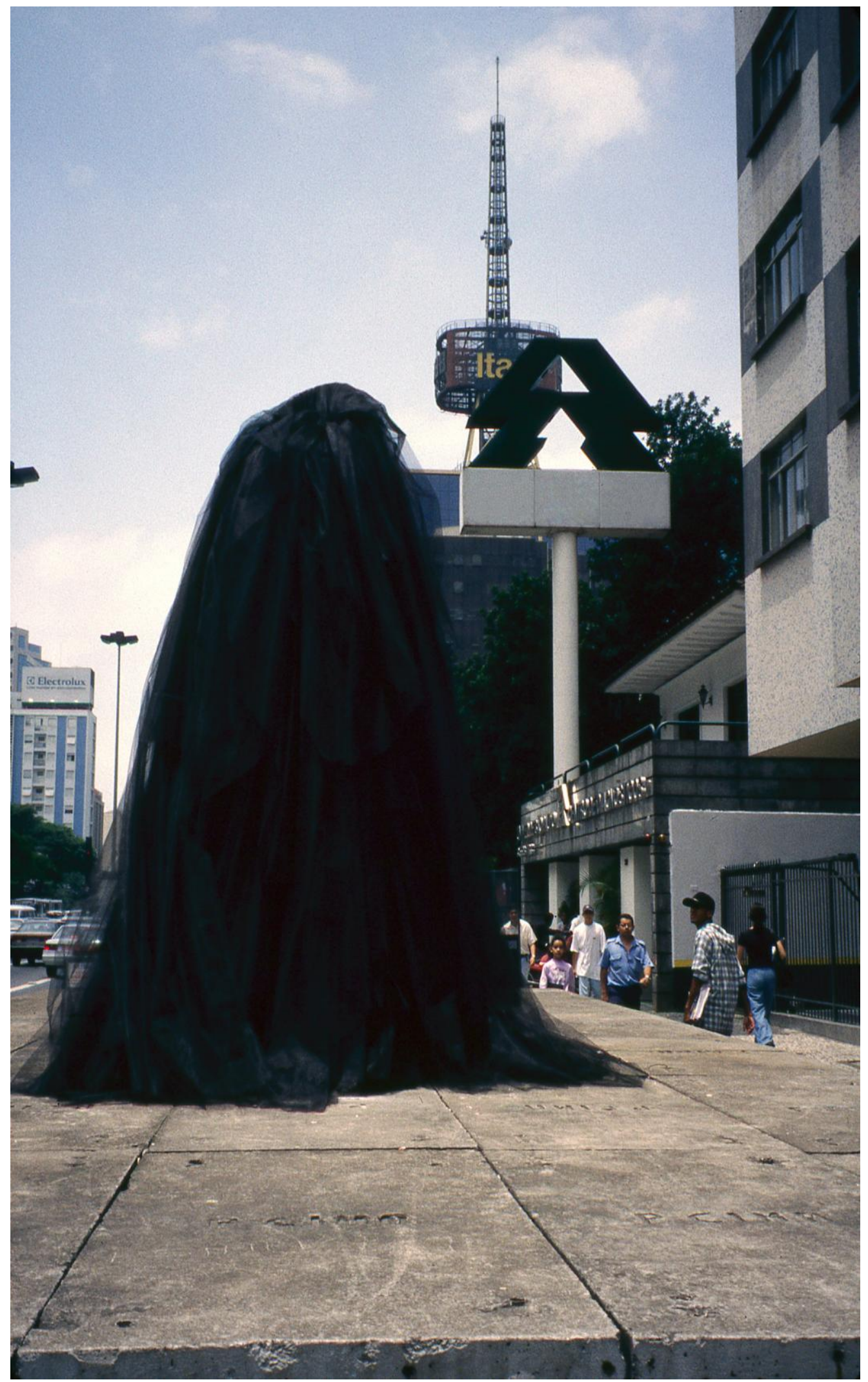

Figura 49 - A Negra 


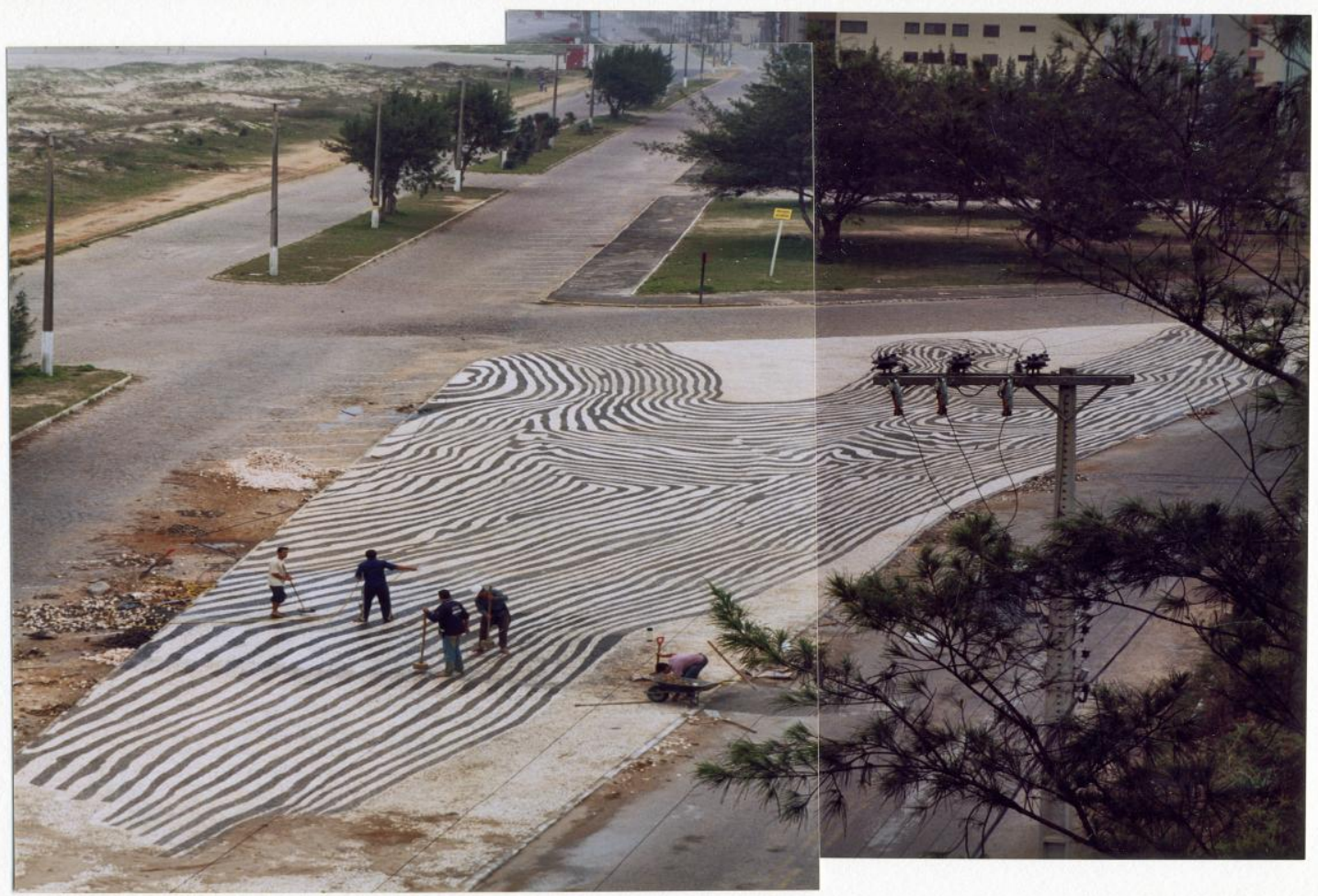

Figura 50 - Fonte/Foz

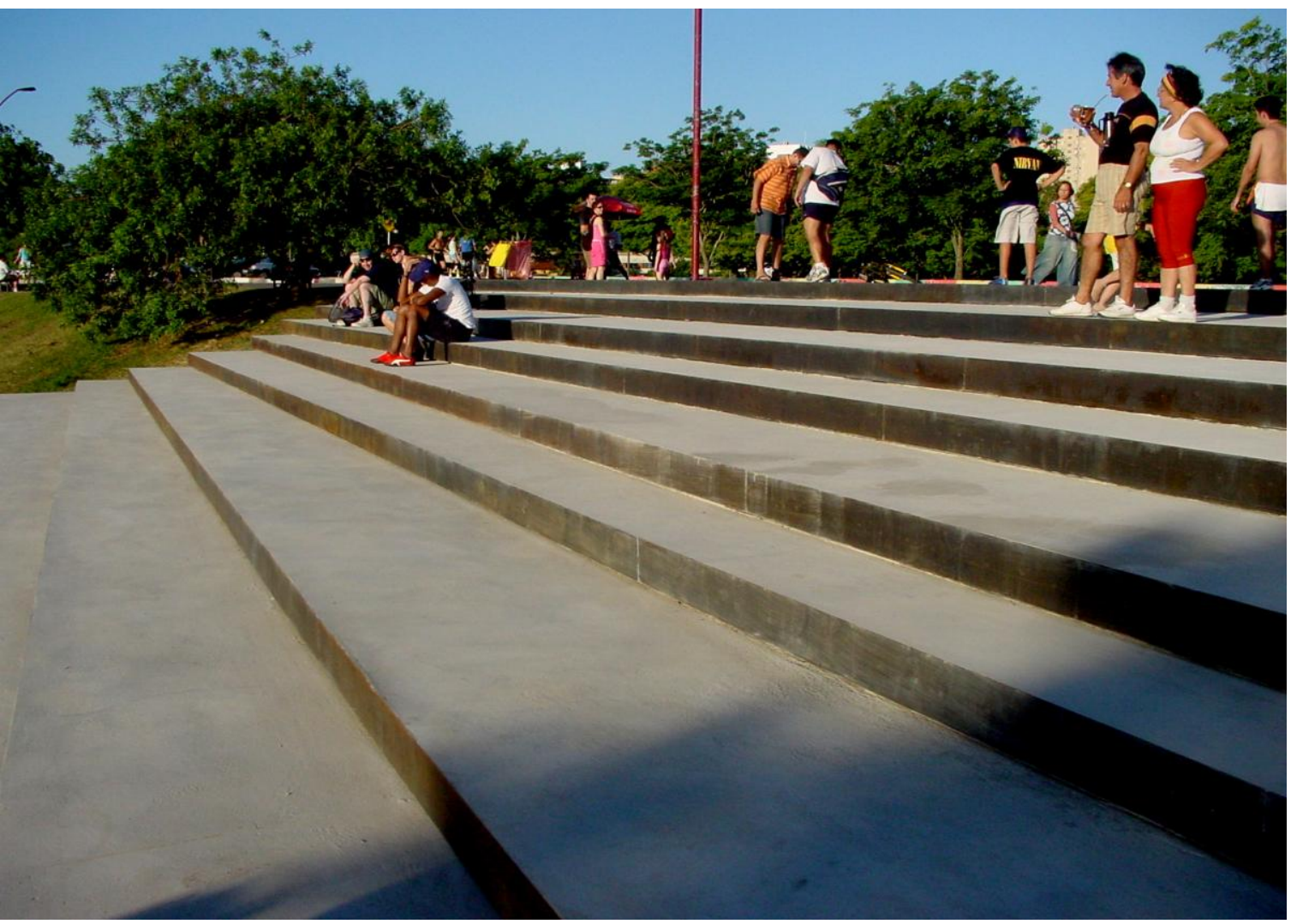

Figura 51 - Cascata 


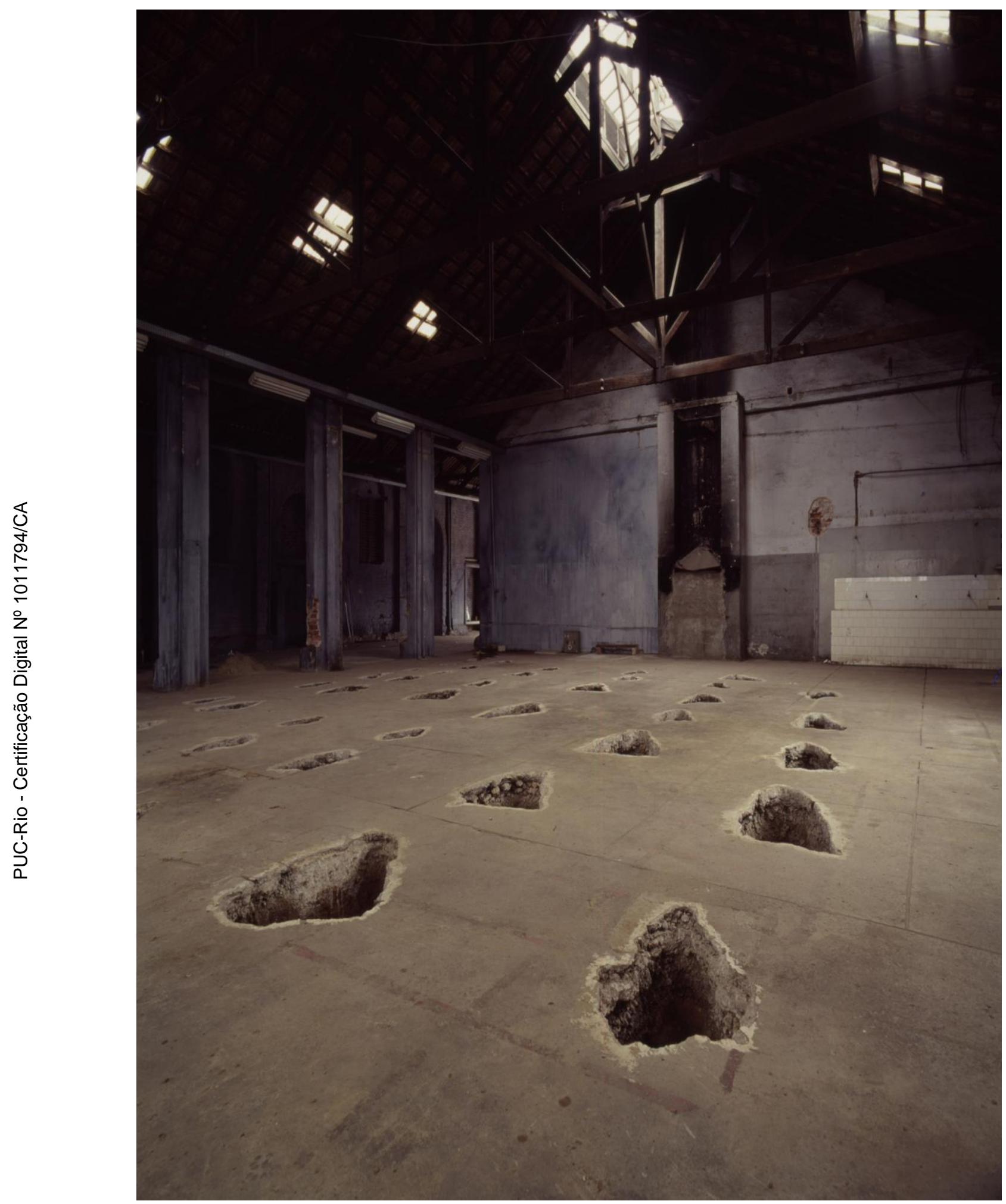

Figura 52 - Buracos 


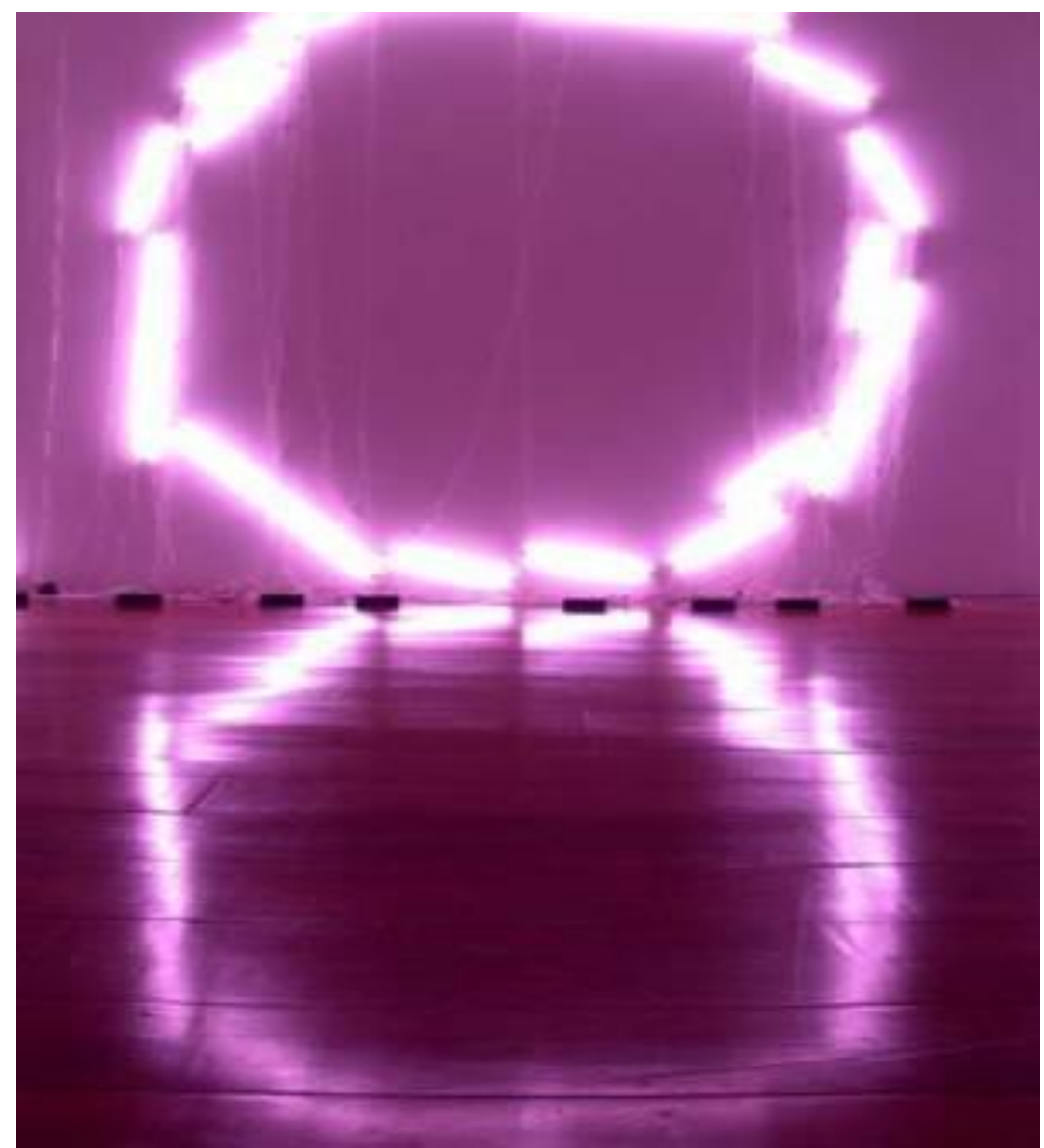

Figura 53 - Aurora

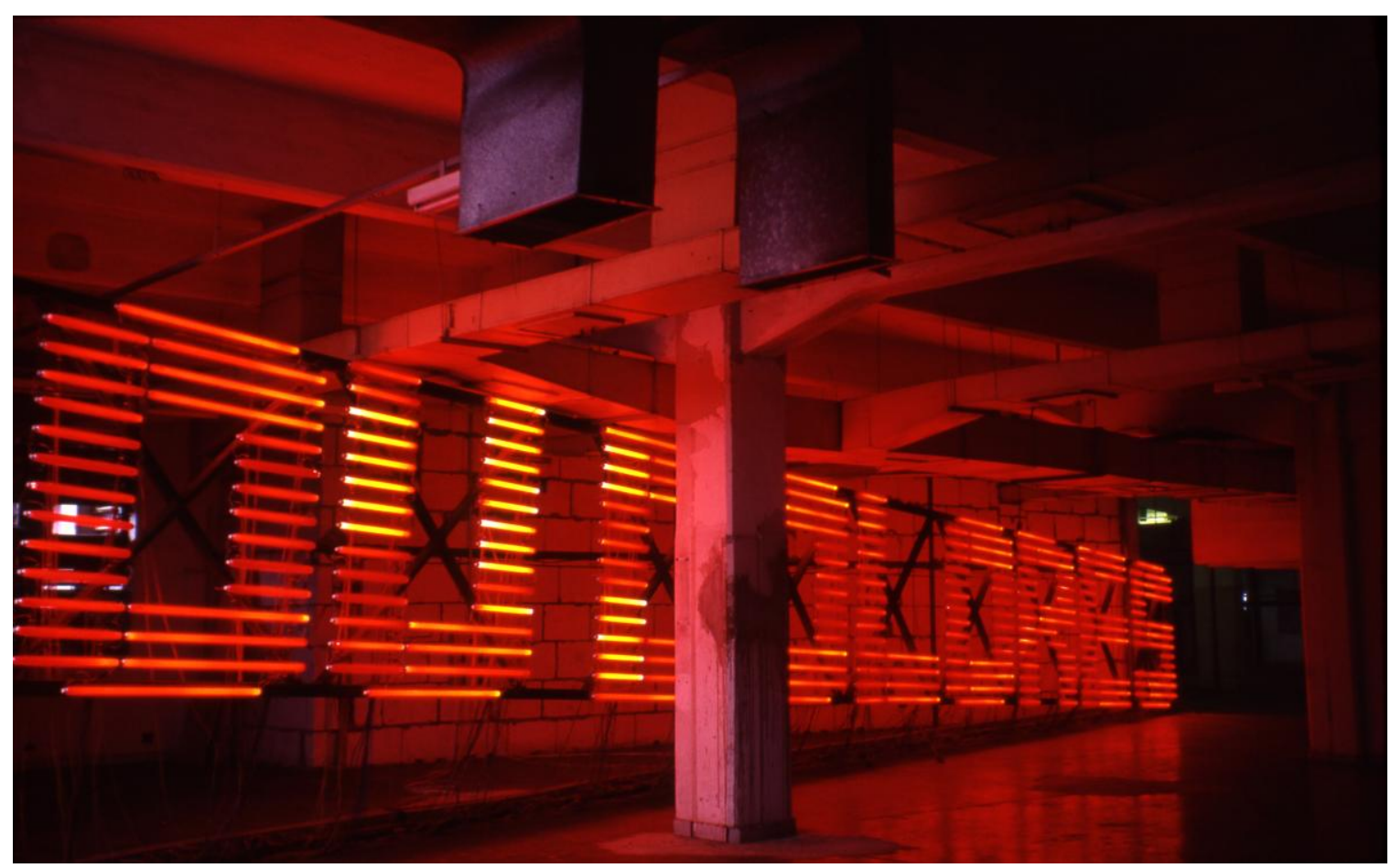

Figura 54 - Eu Sou Dolores 


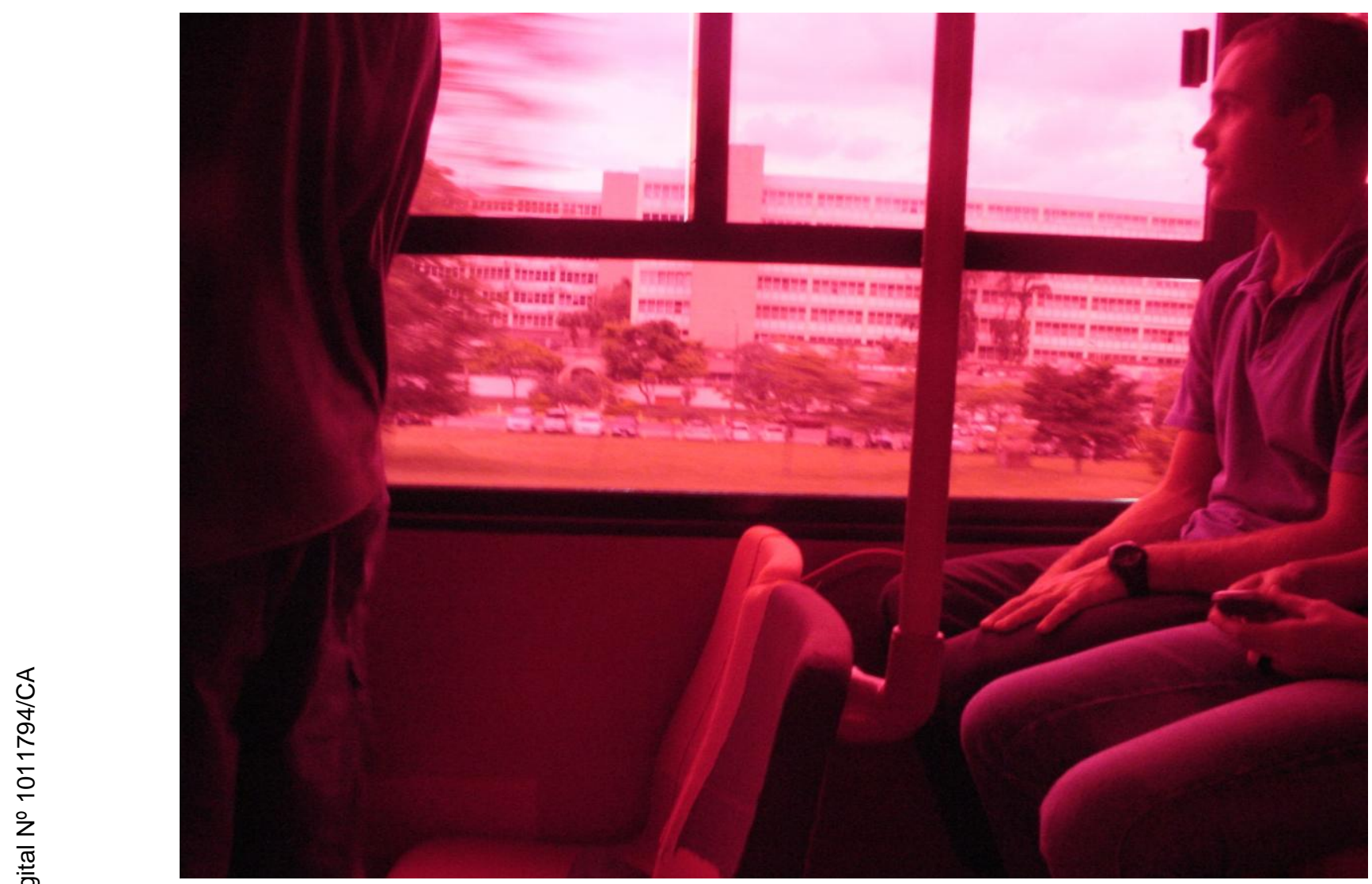

Figura 55 - Carne

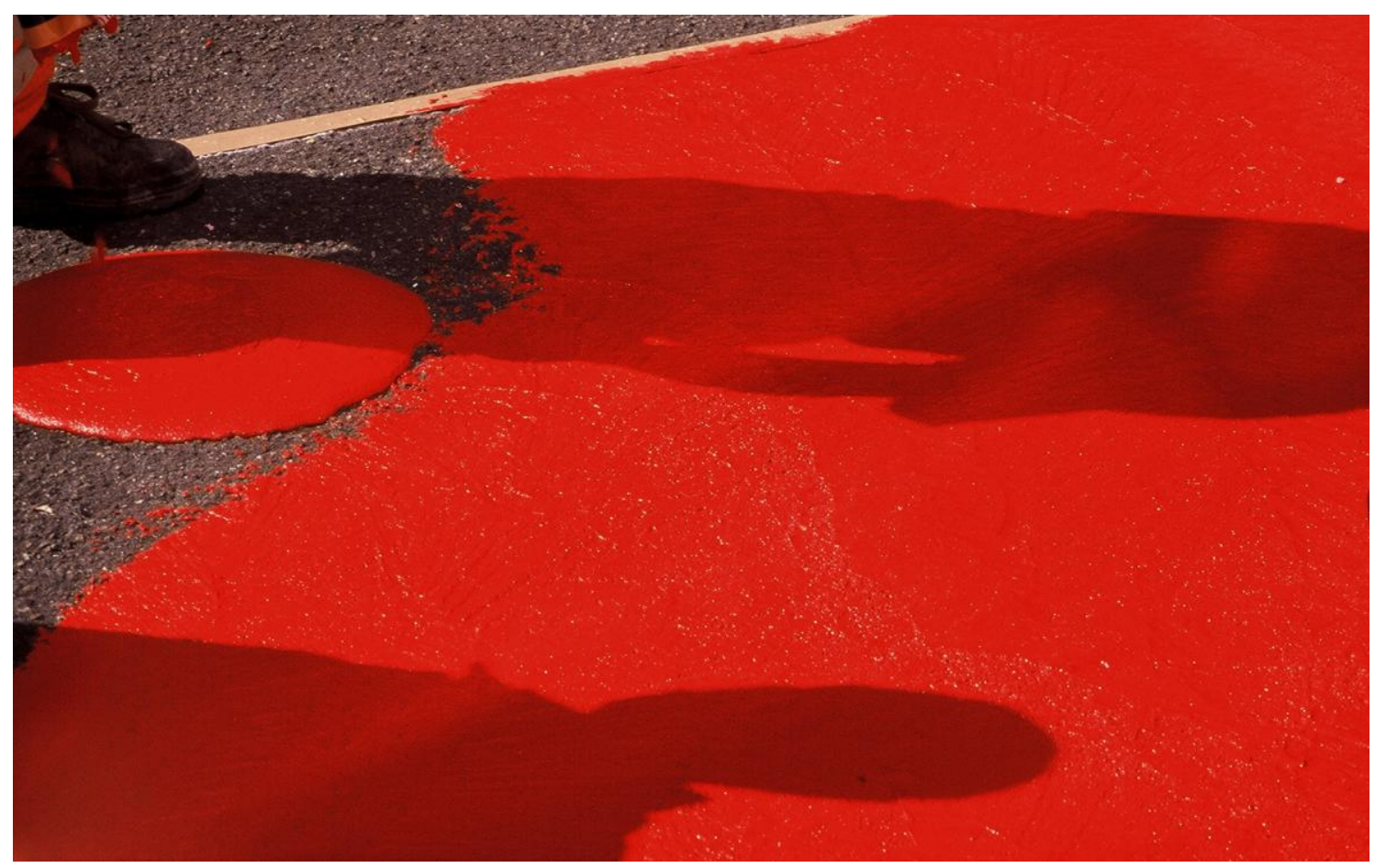

Figura 56 - bleu, jaune, rouge, rouge 


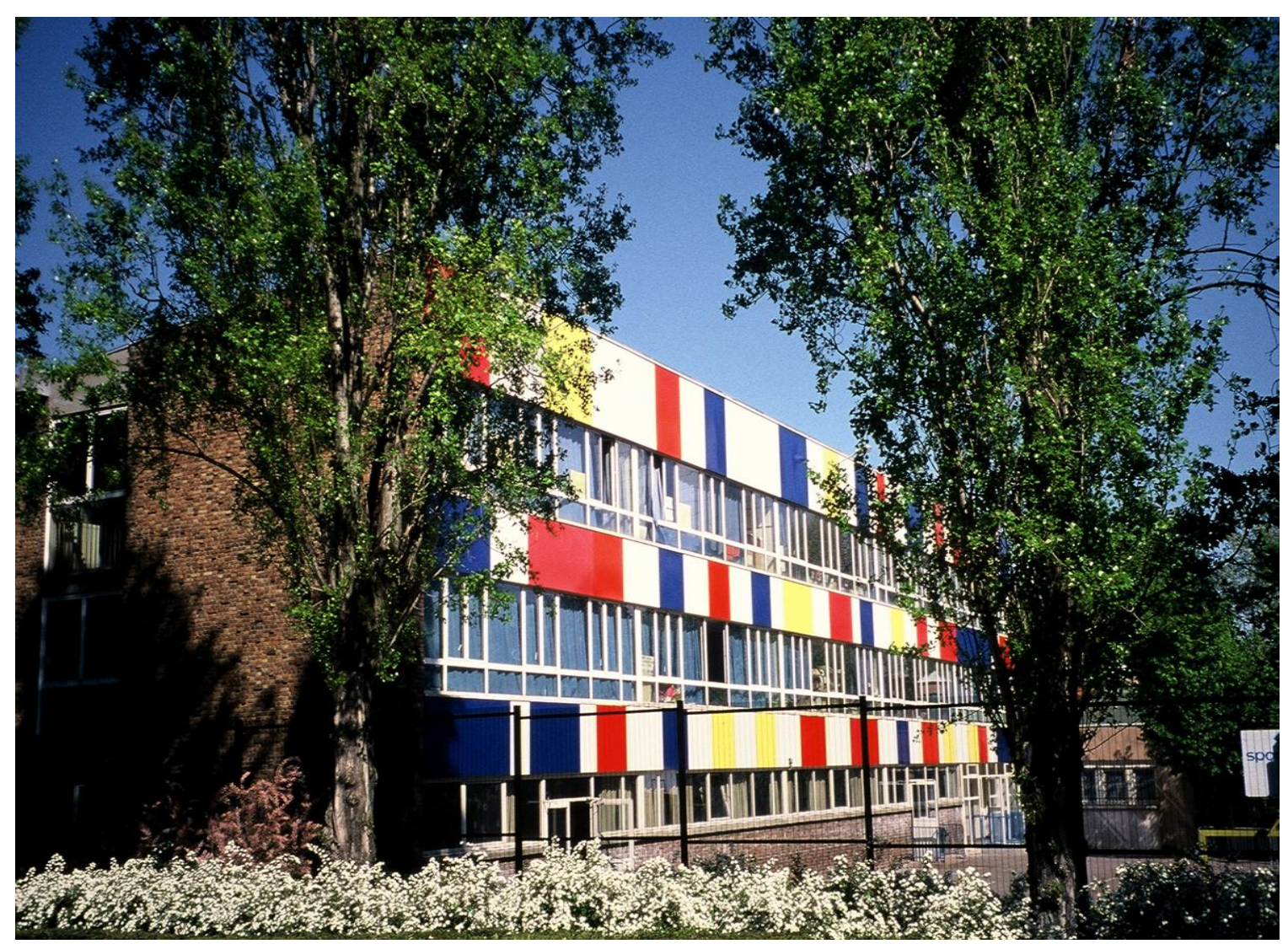

Figura 57 - bleu, jaune, rouge, rouge

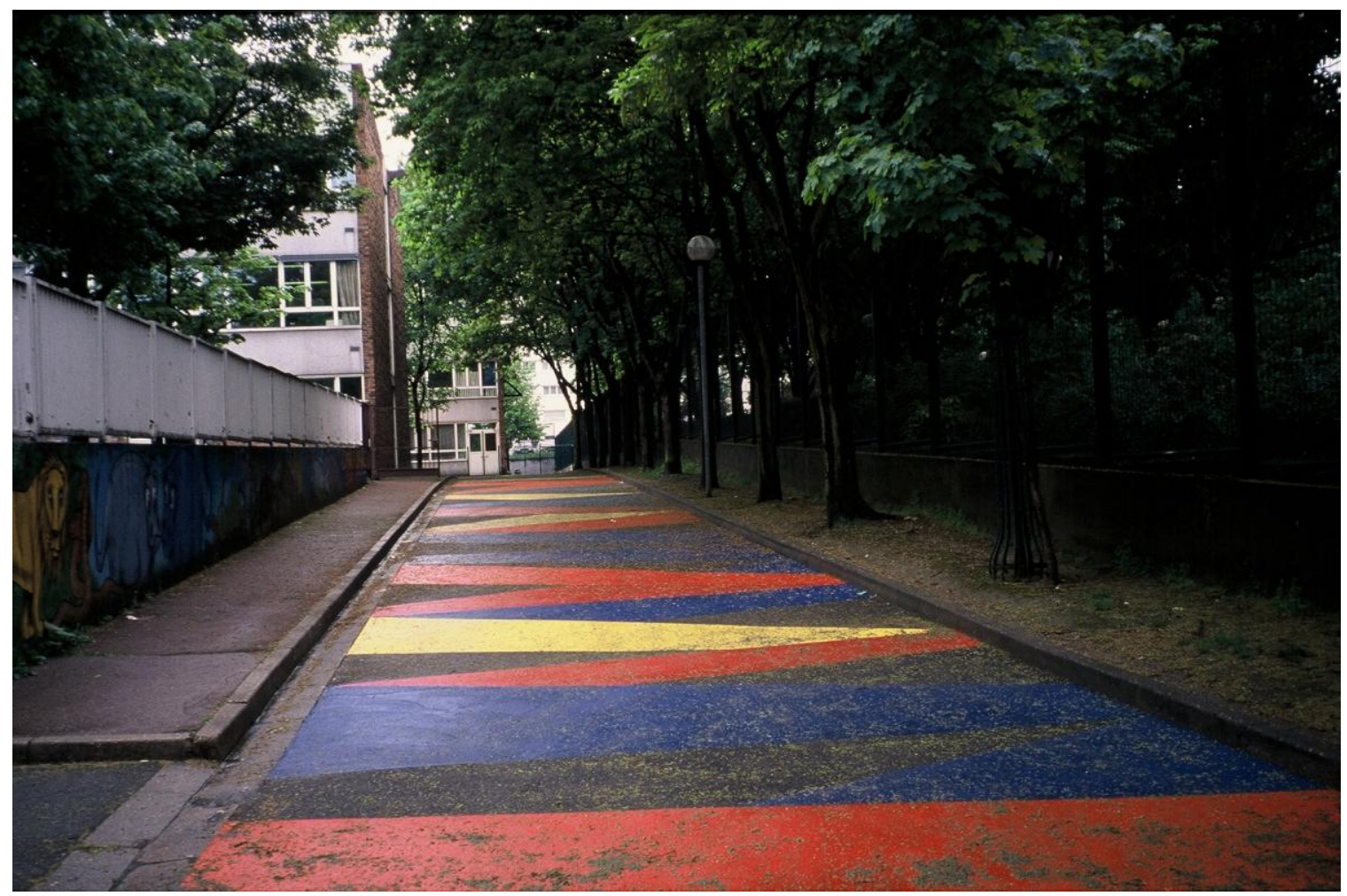

Figura 58 - bleu, jaune, rouge, rouge 


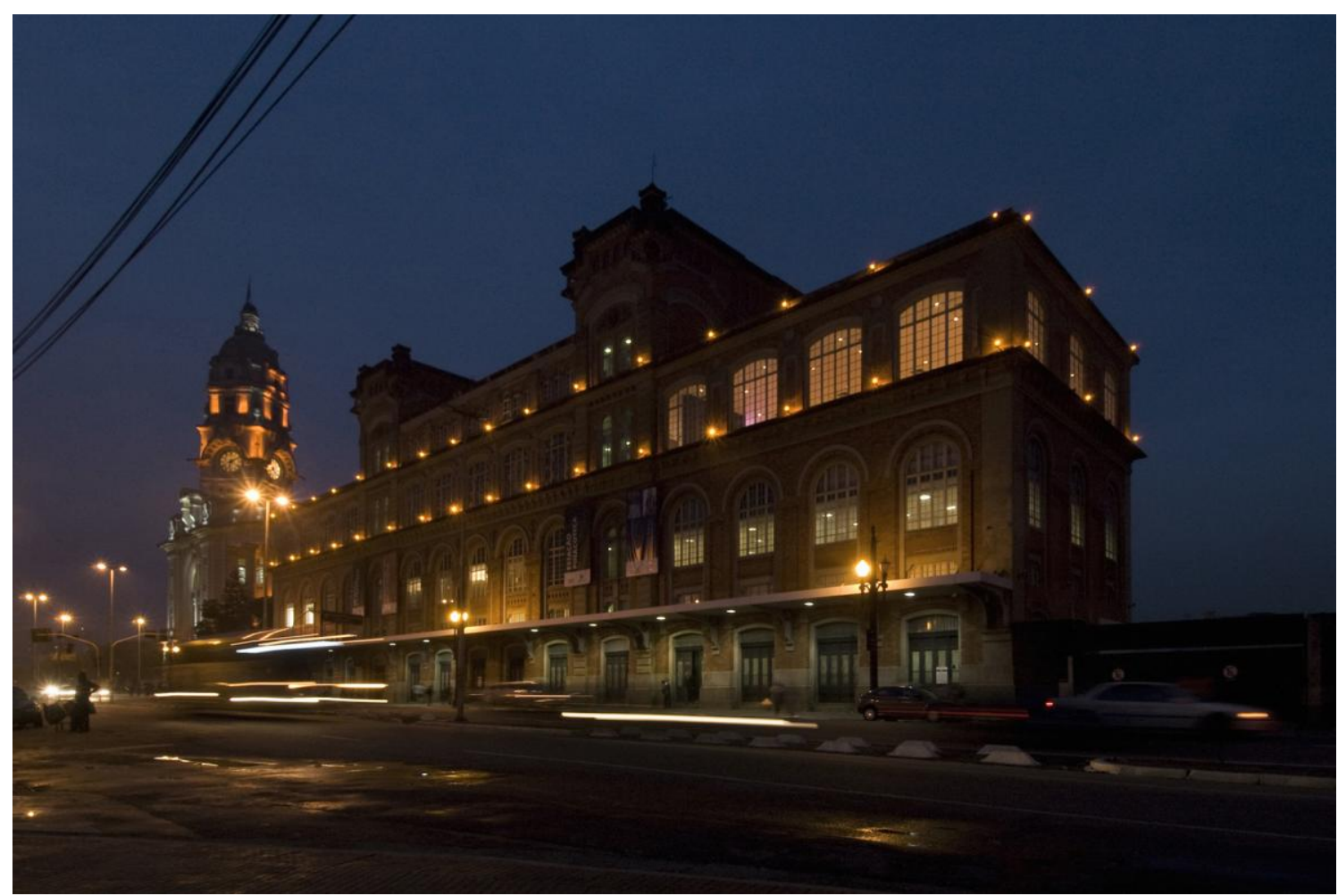

Figura 59 - Iluminuras

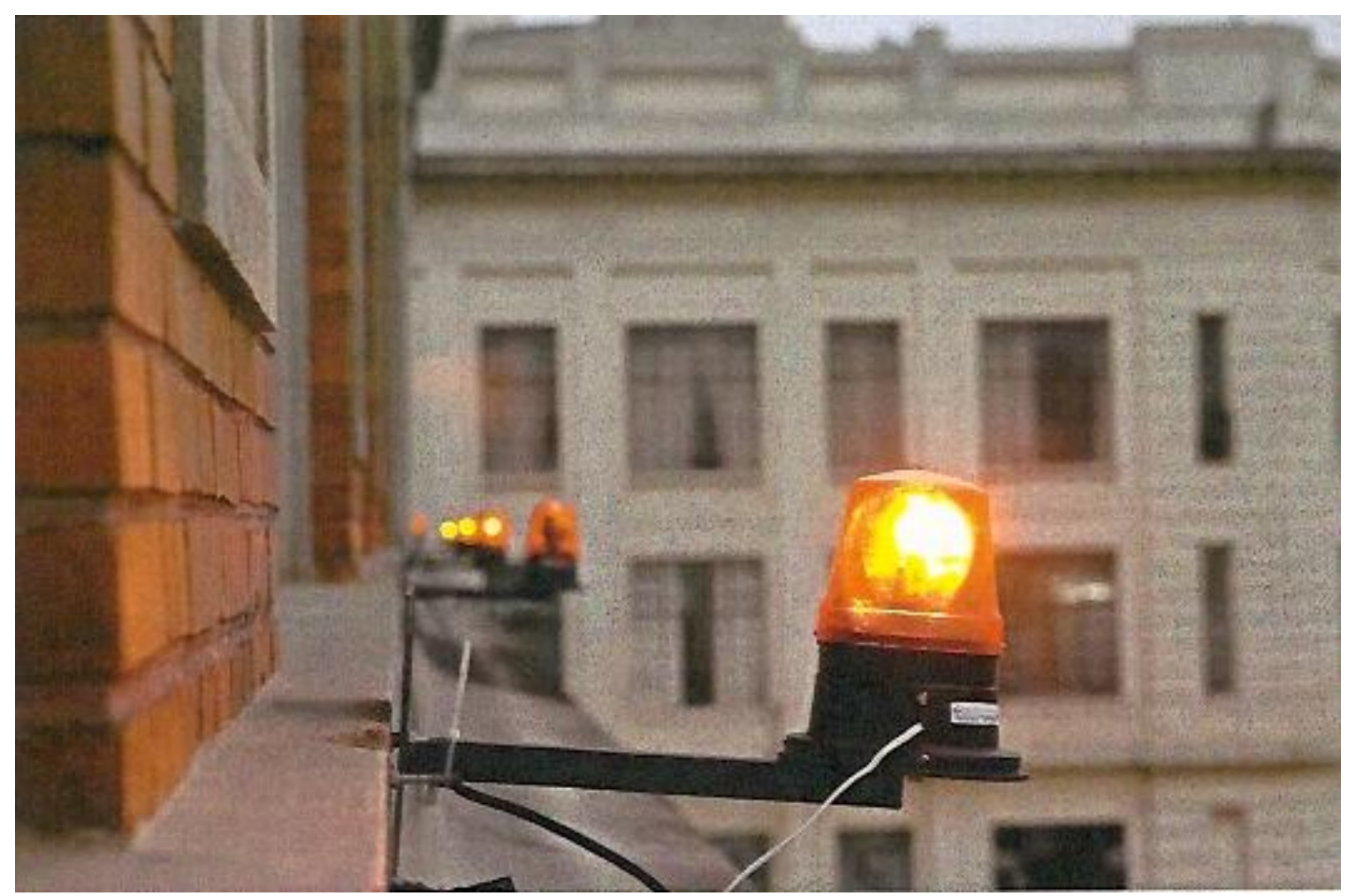

Figura 60 - Iluminuras 


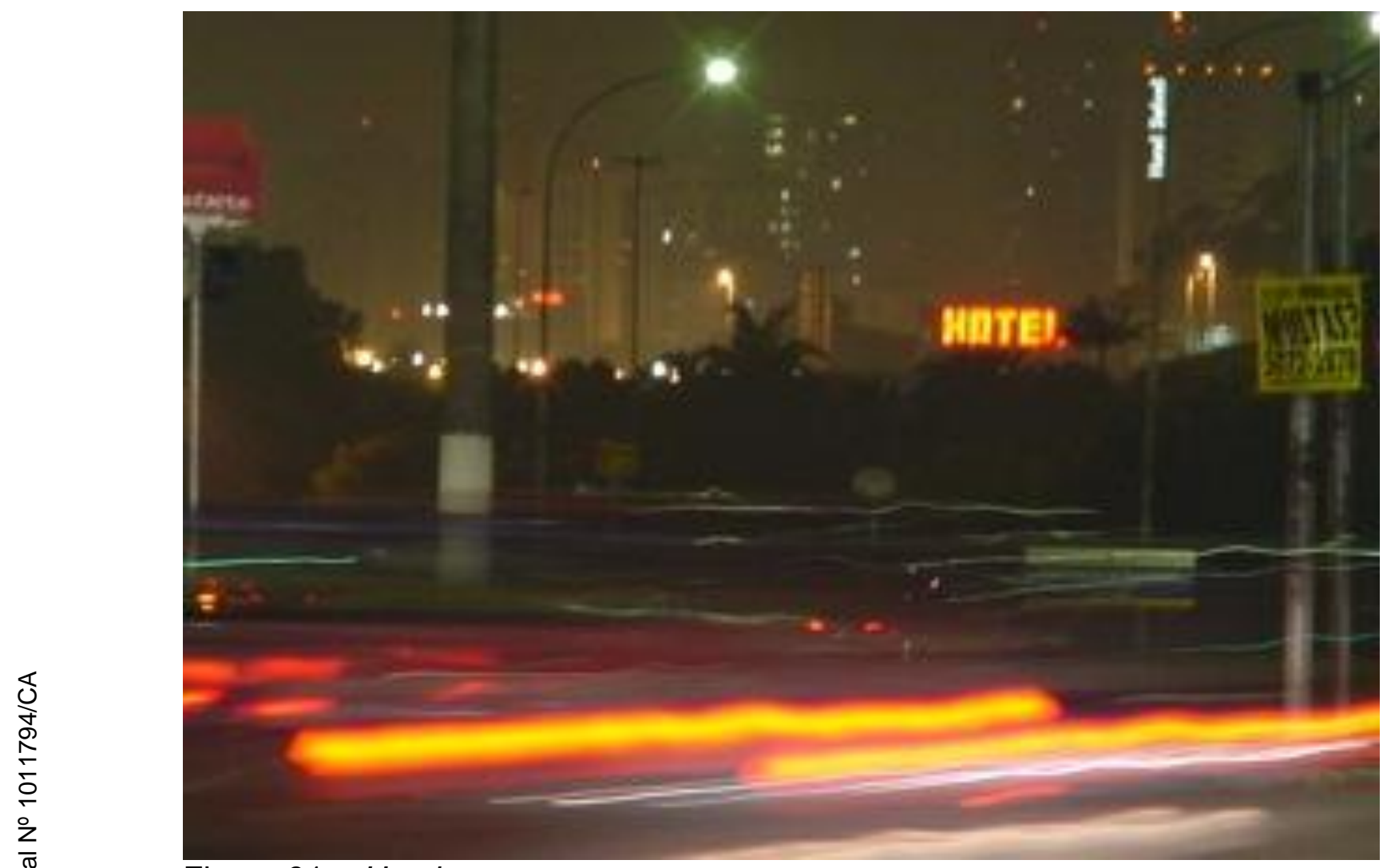

Figura $61-$ Hotel

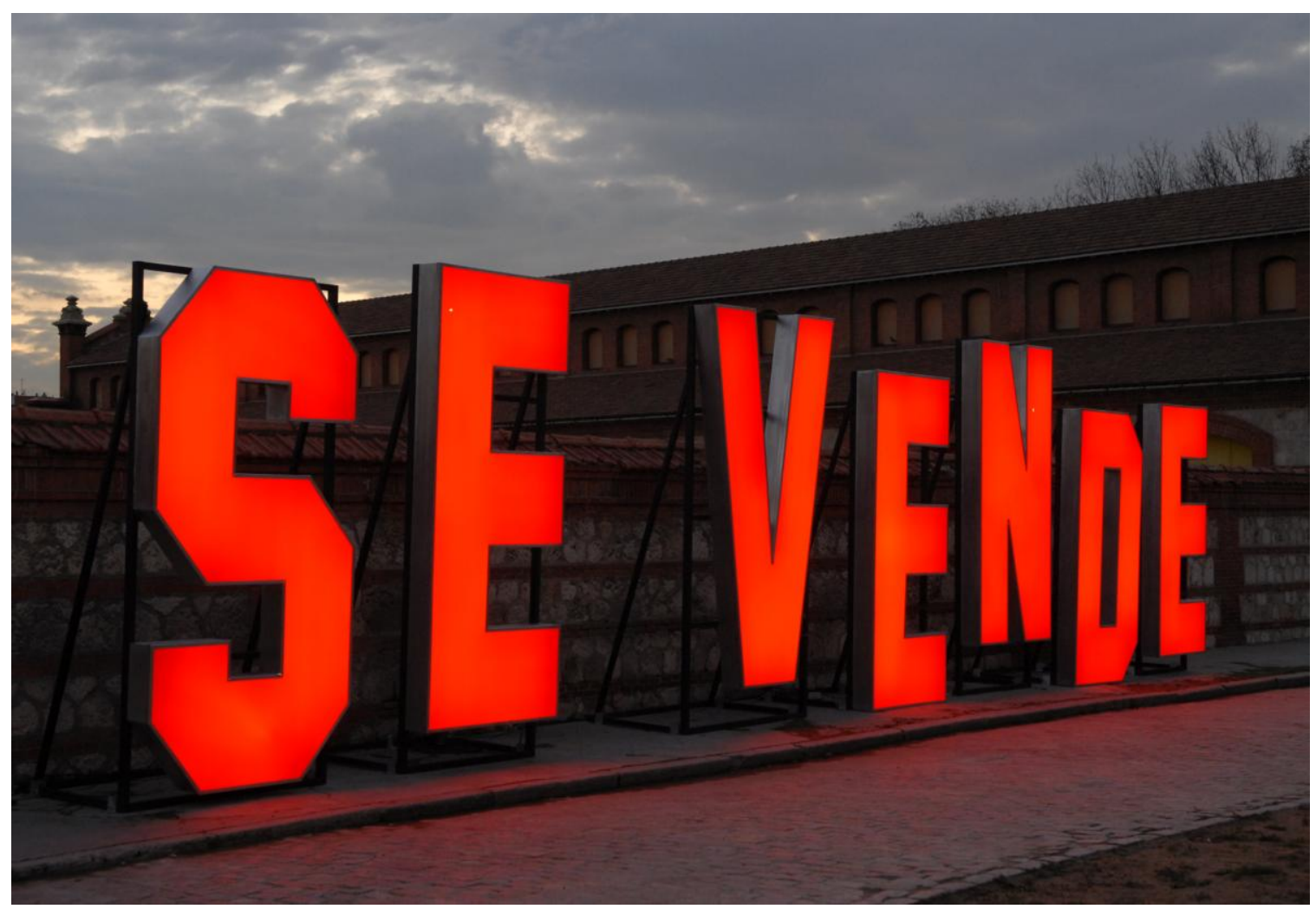

Figura 62 - Se Vende, feira de arte ARCO, Madrid 


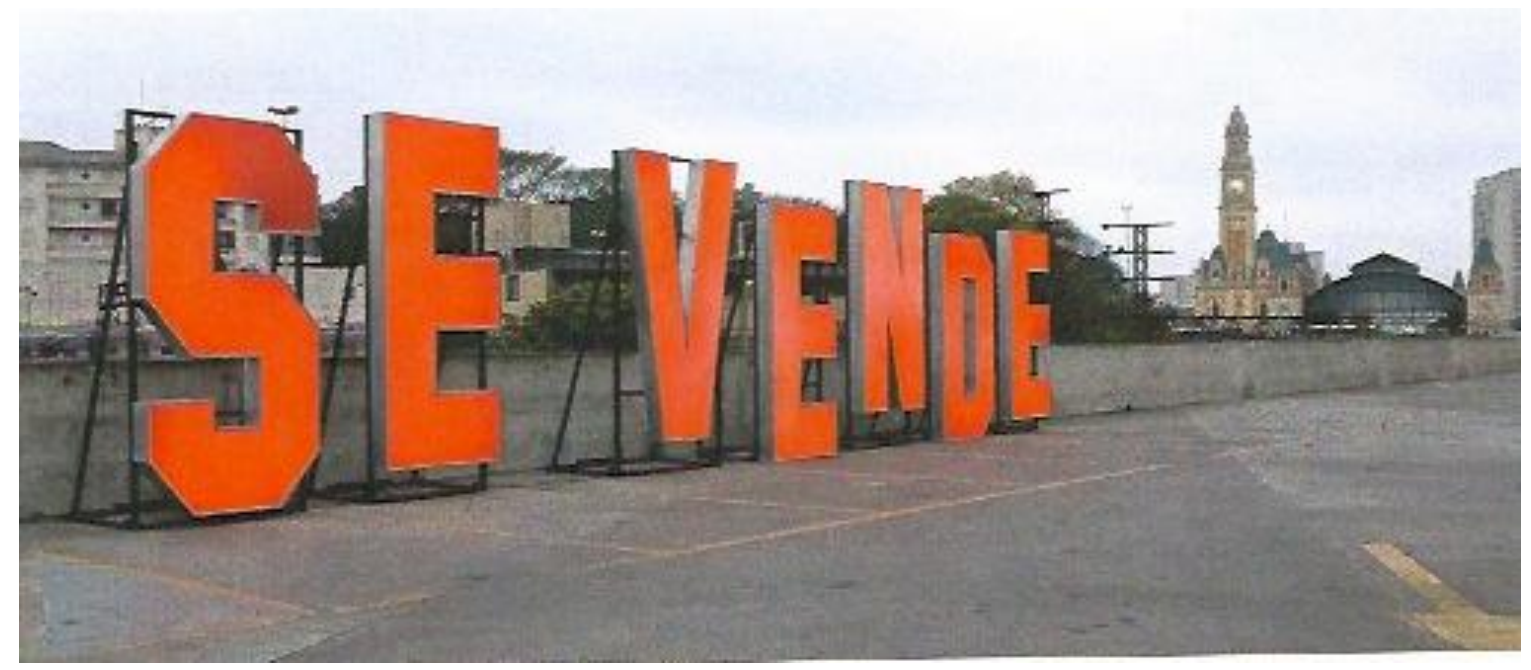

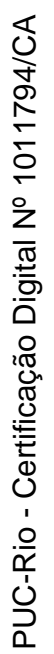
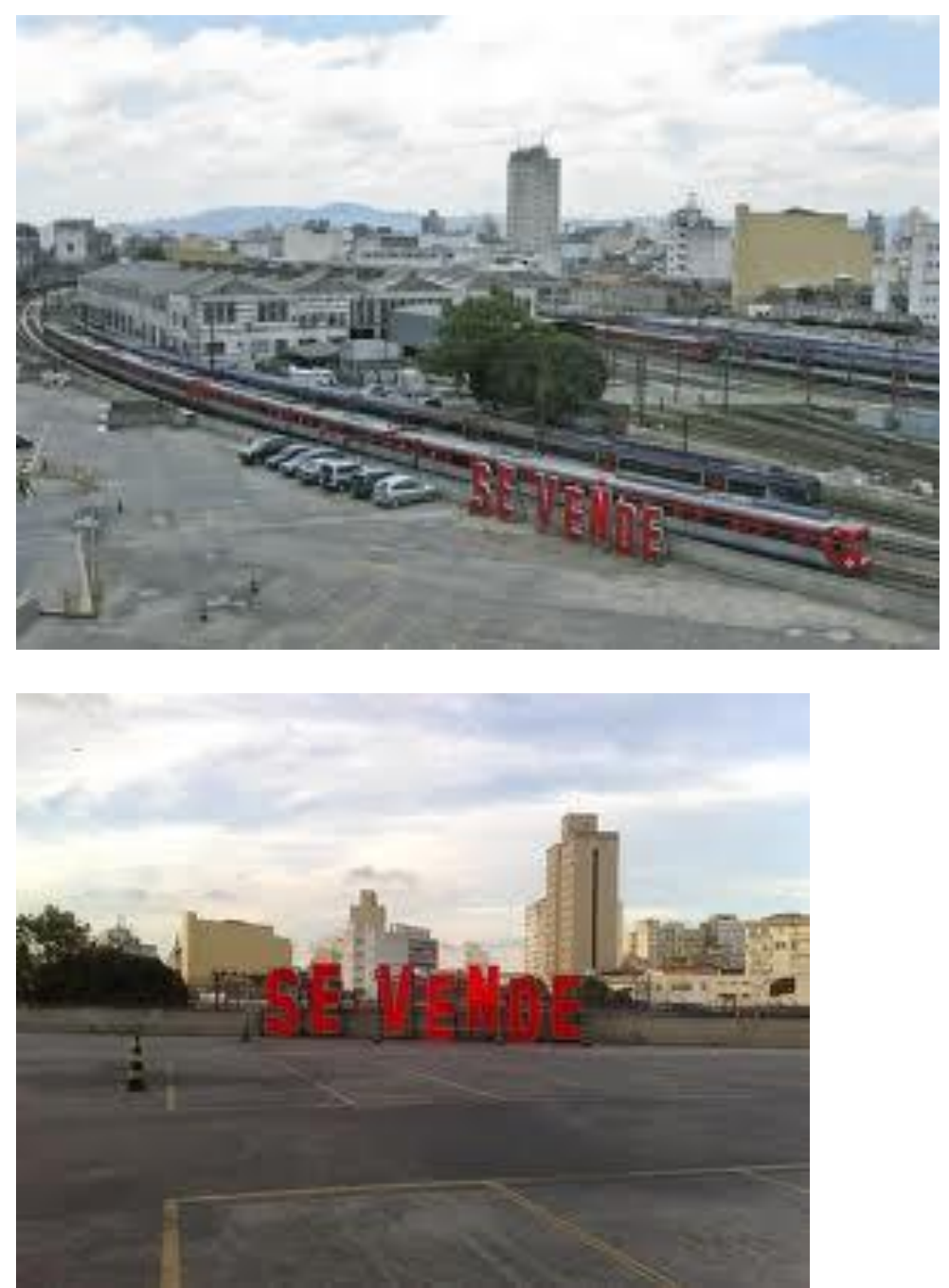

Figura 63 - Se Vende, estacionamento da Estação Pinacoteca, São Paulo 


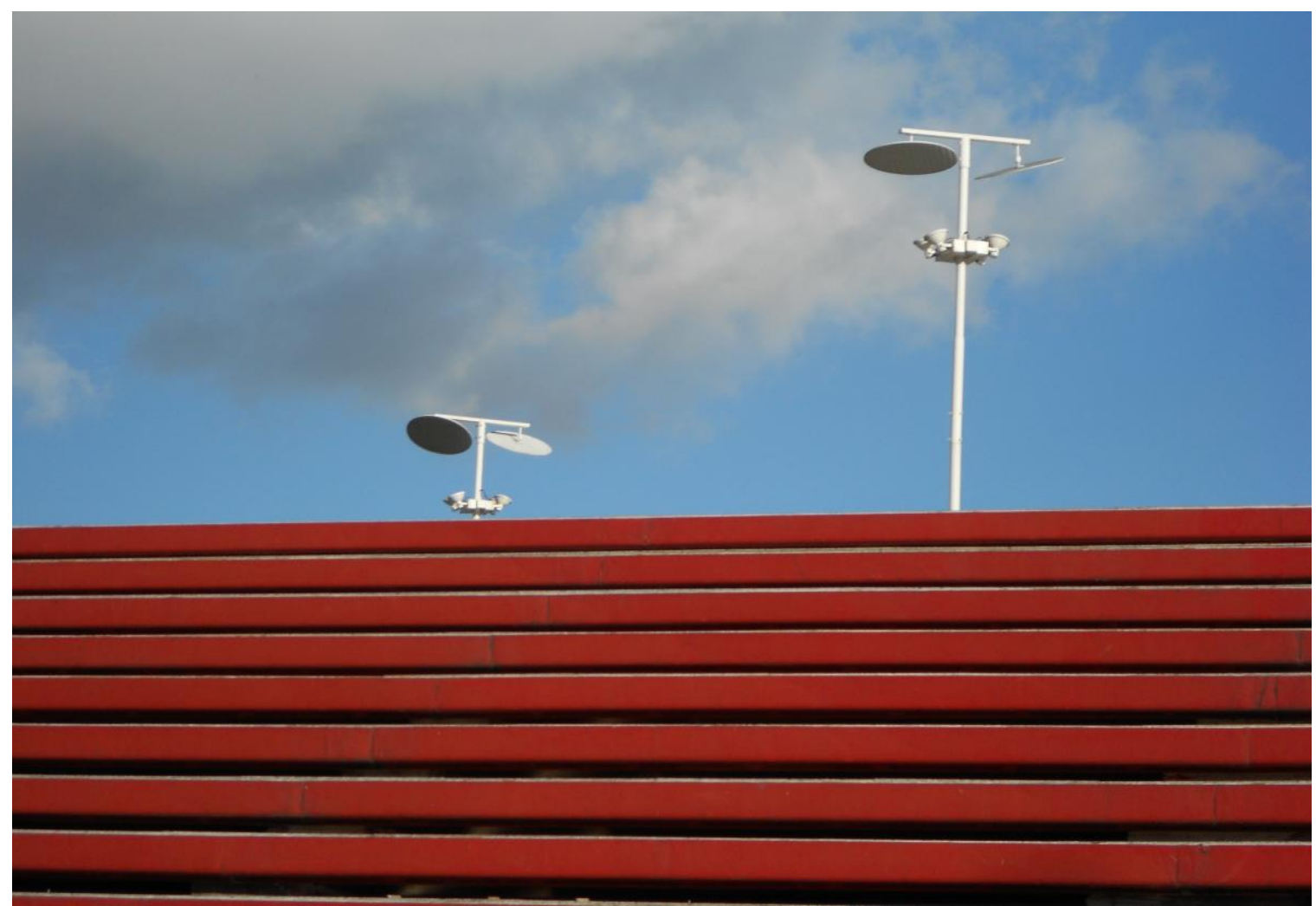

Figura 64 - Escada de entrada, SESC Belenzinho, São Paulo

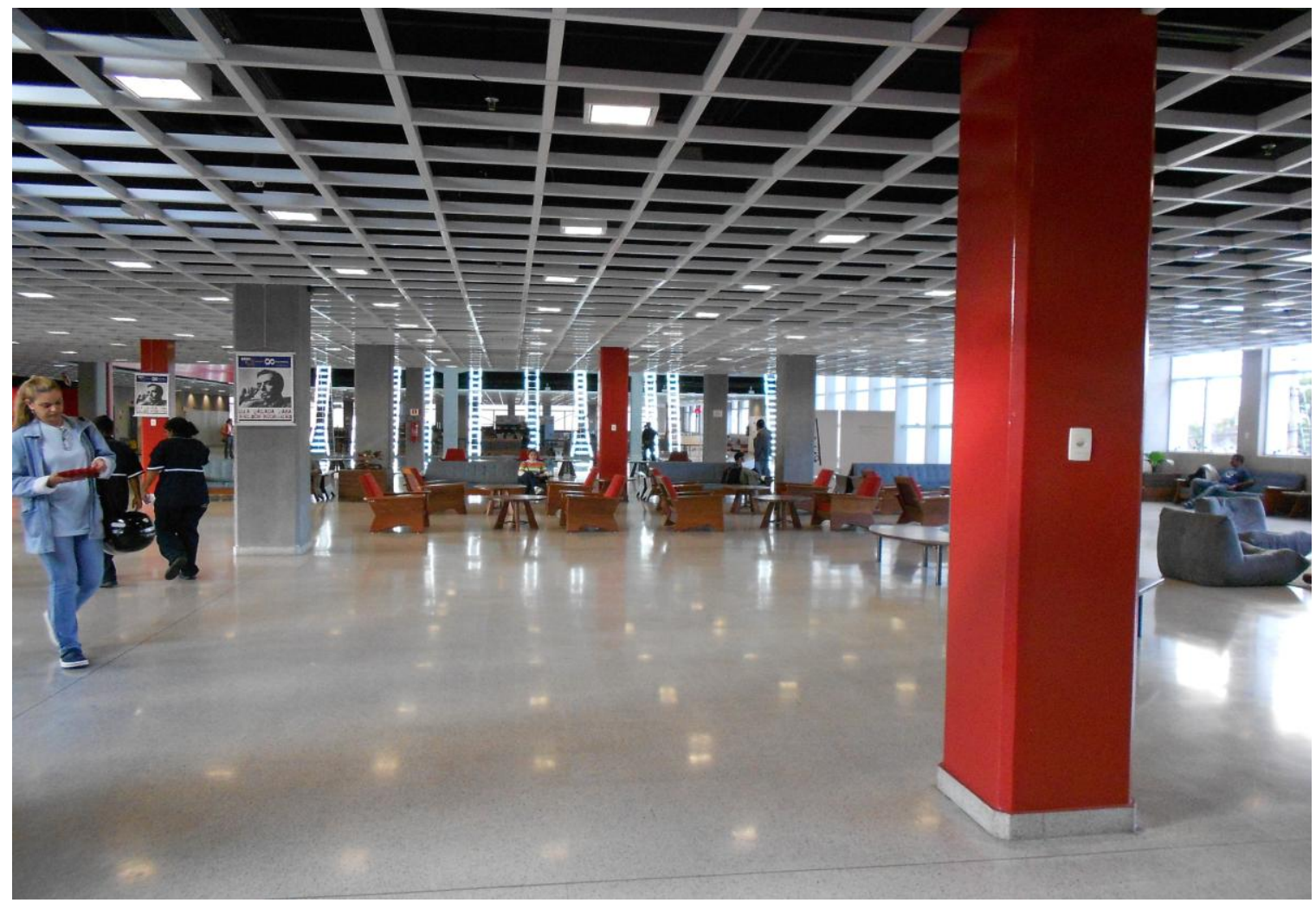

Figura 65 em diante - Instalação Escadas, SESC Belenzinho, São Paulo 


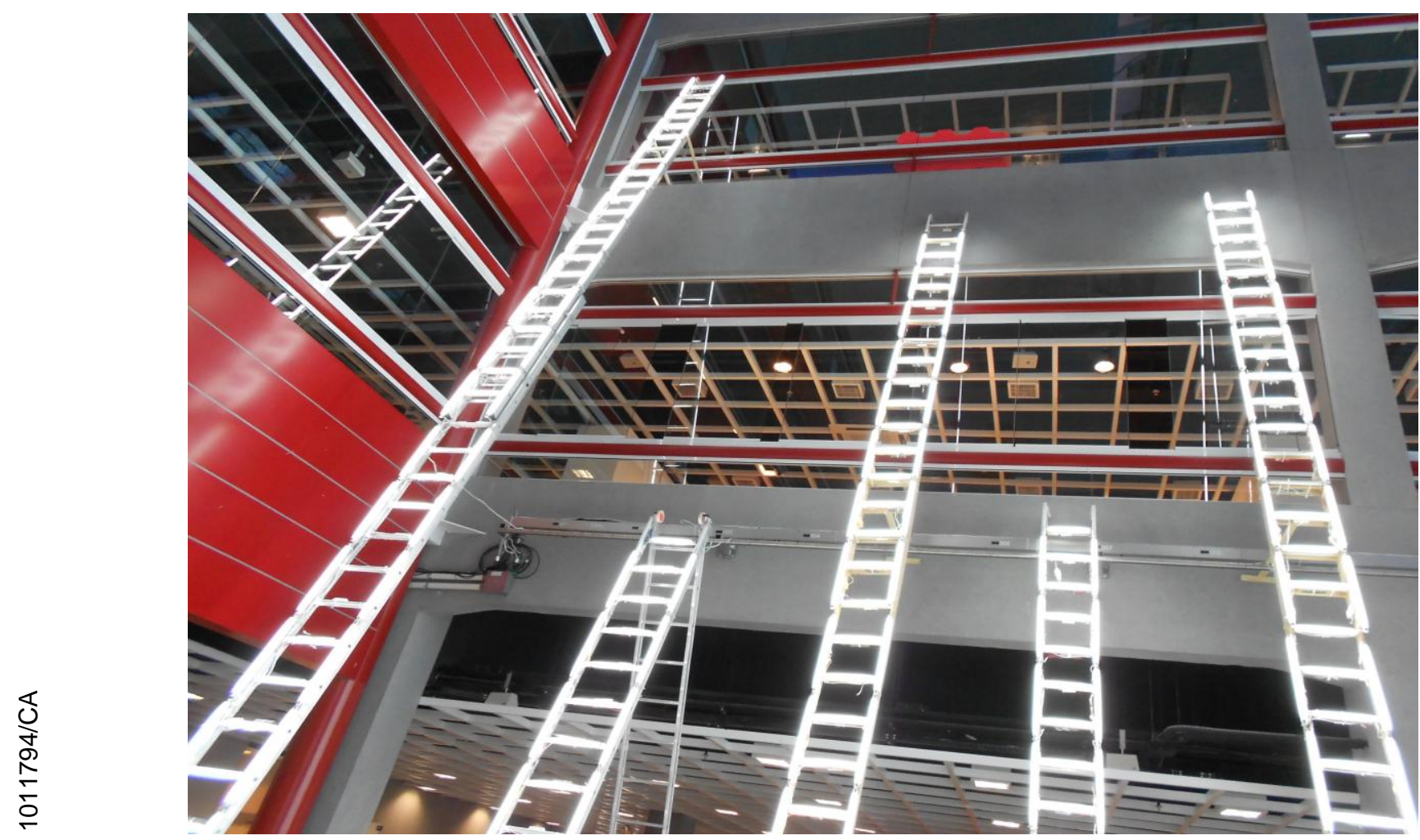

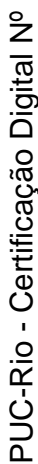

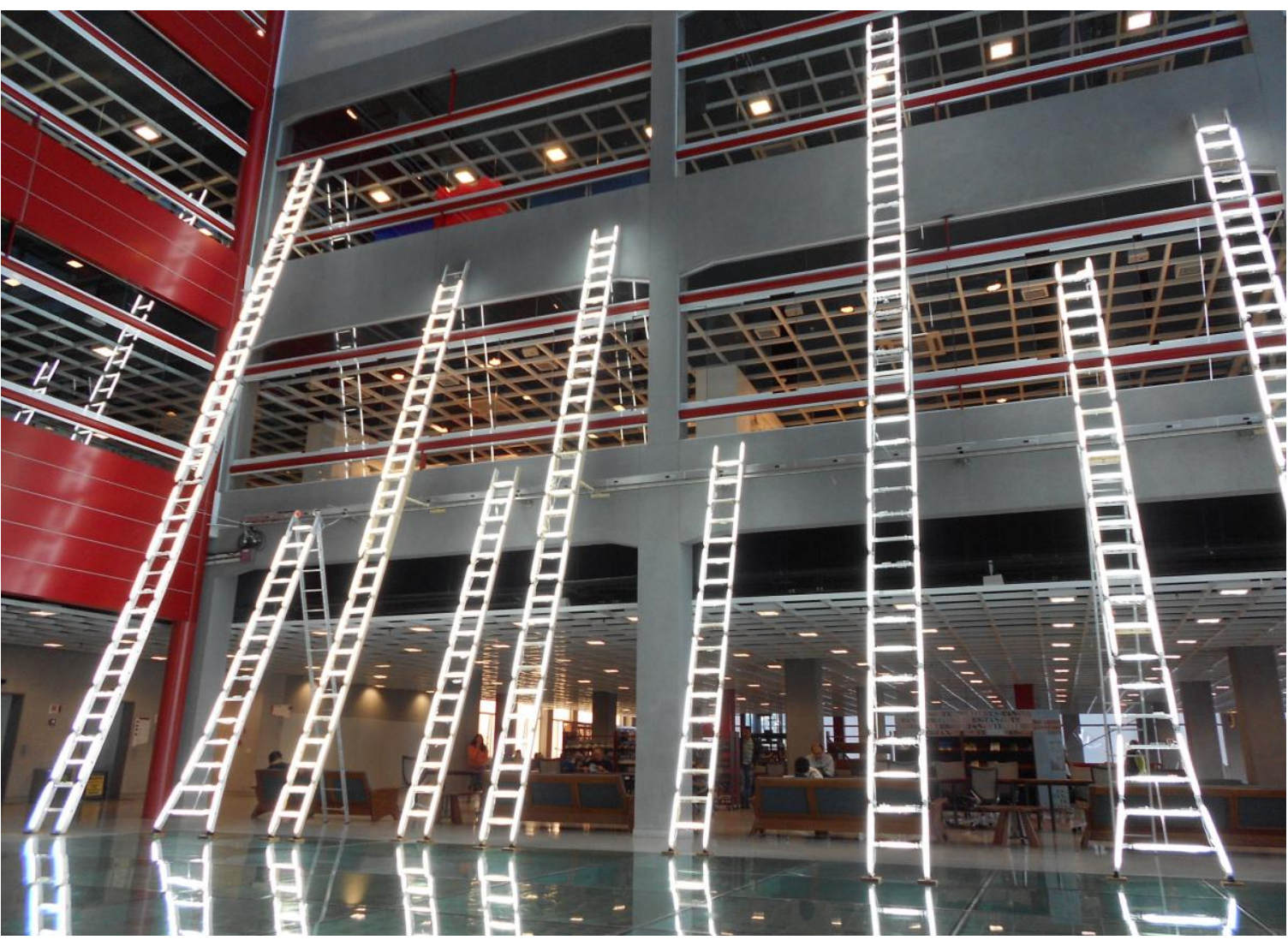




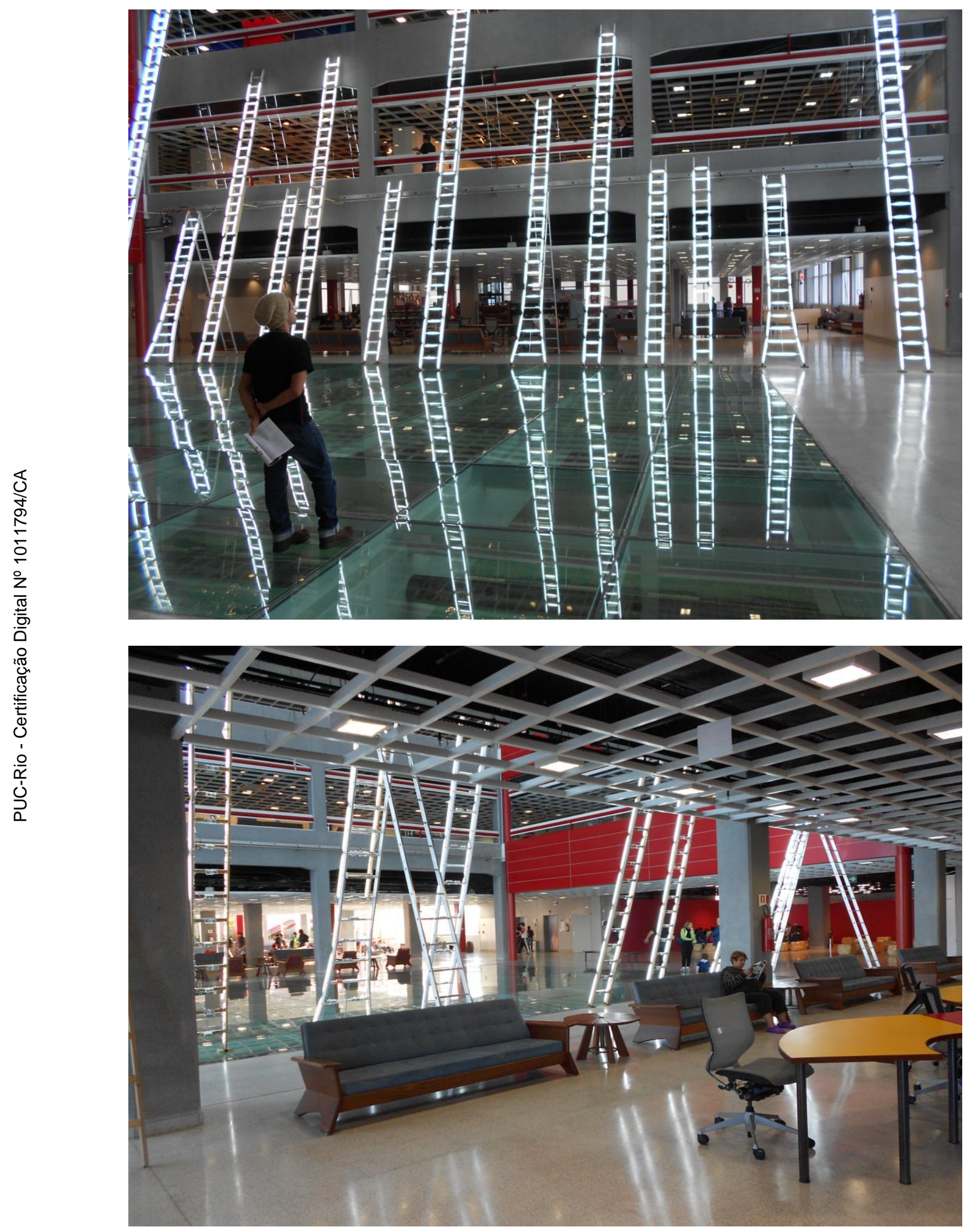




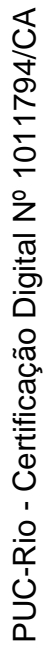
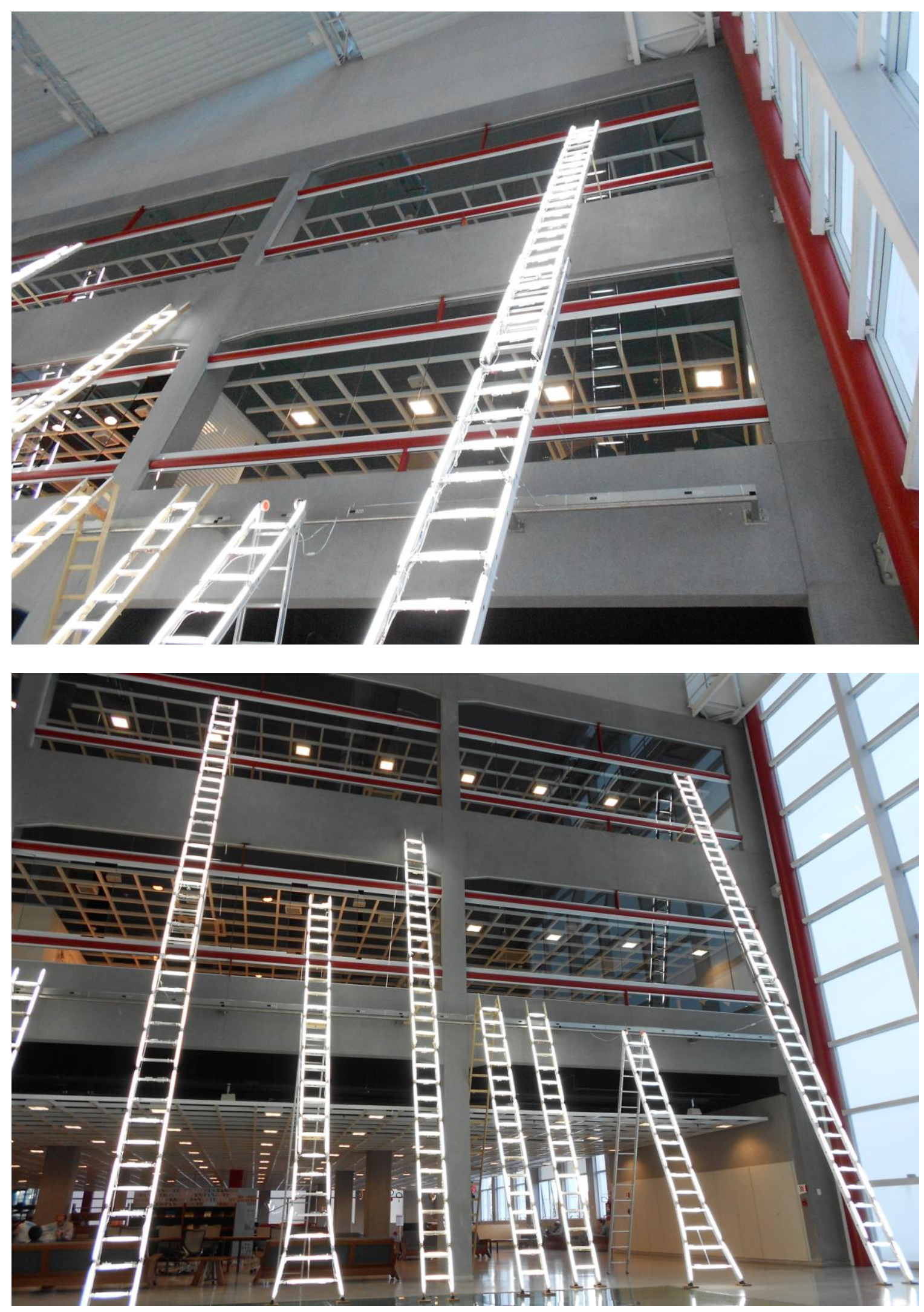

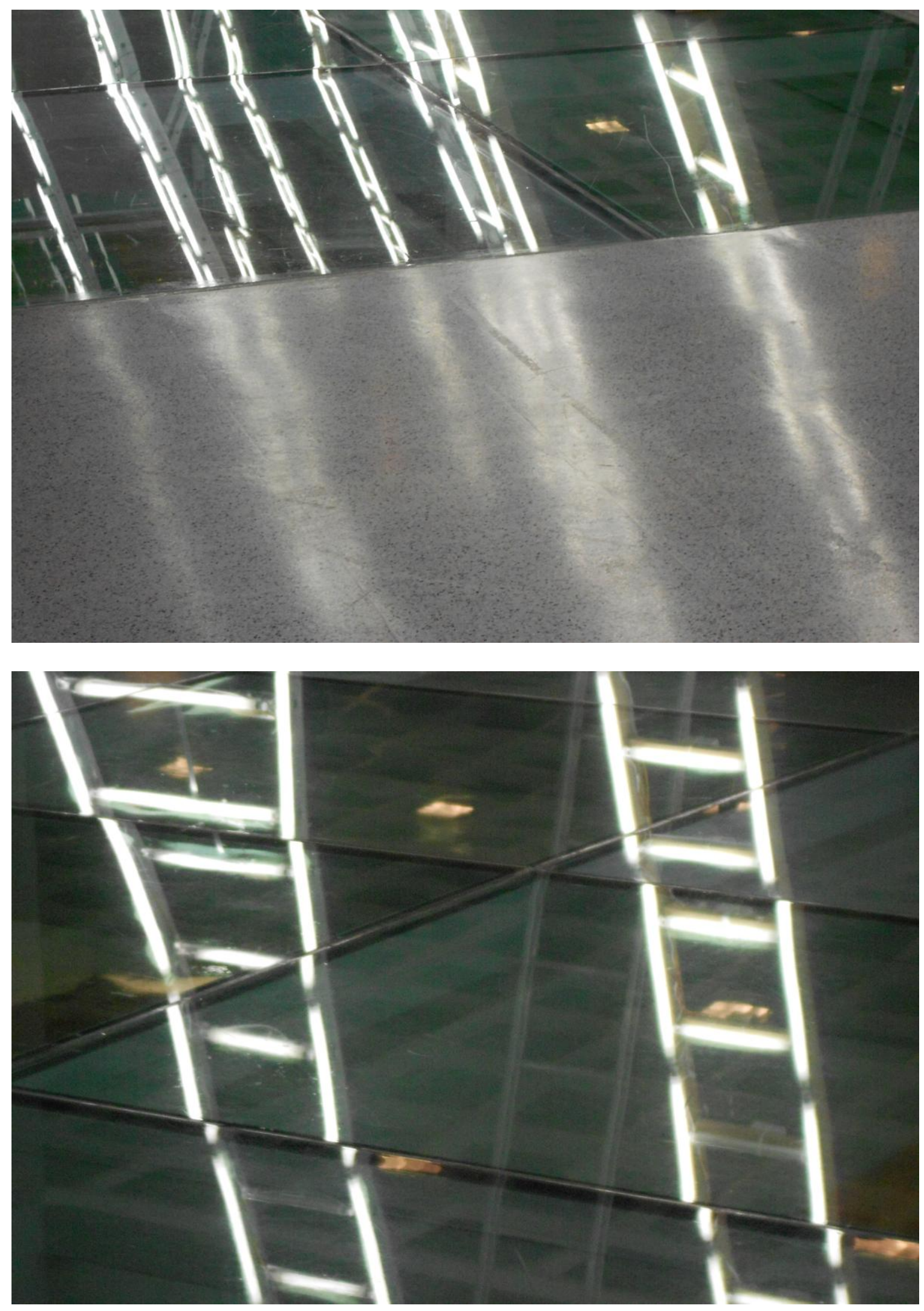


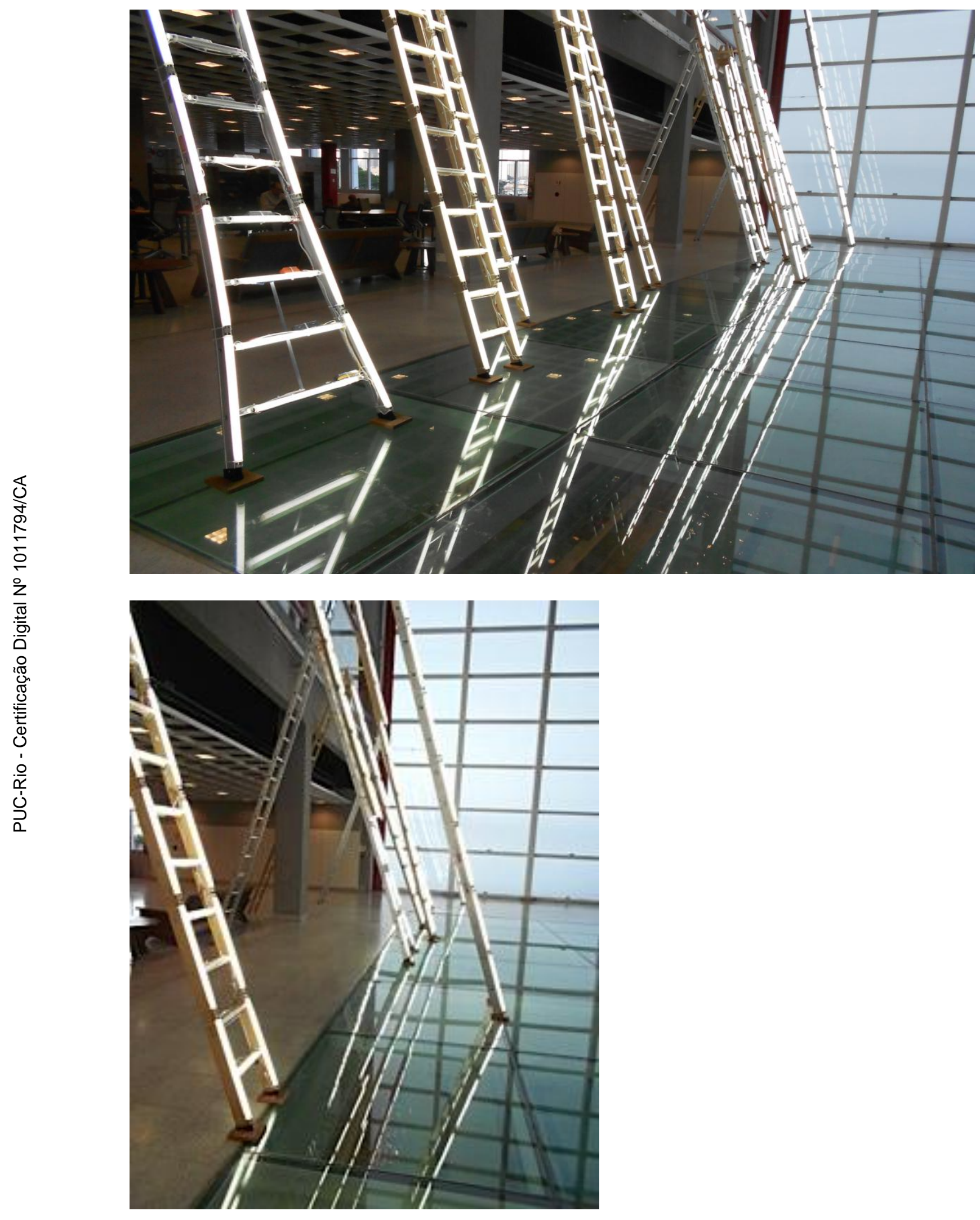




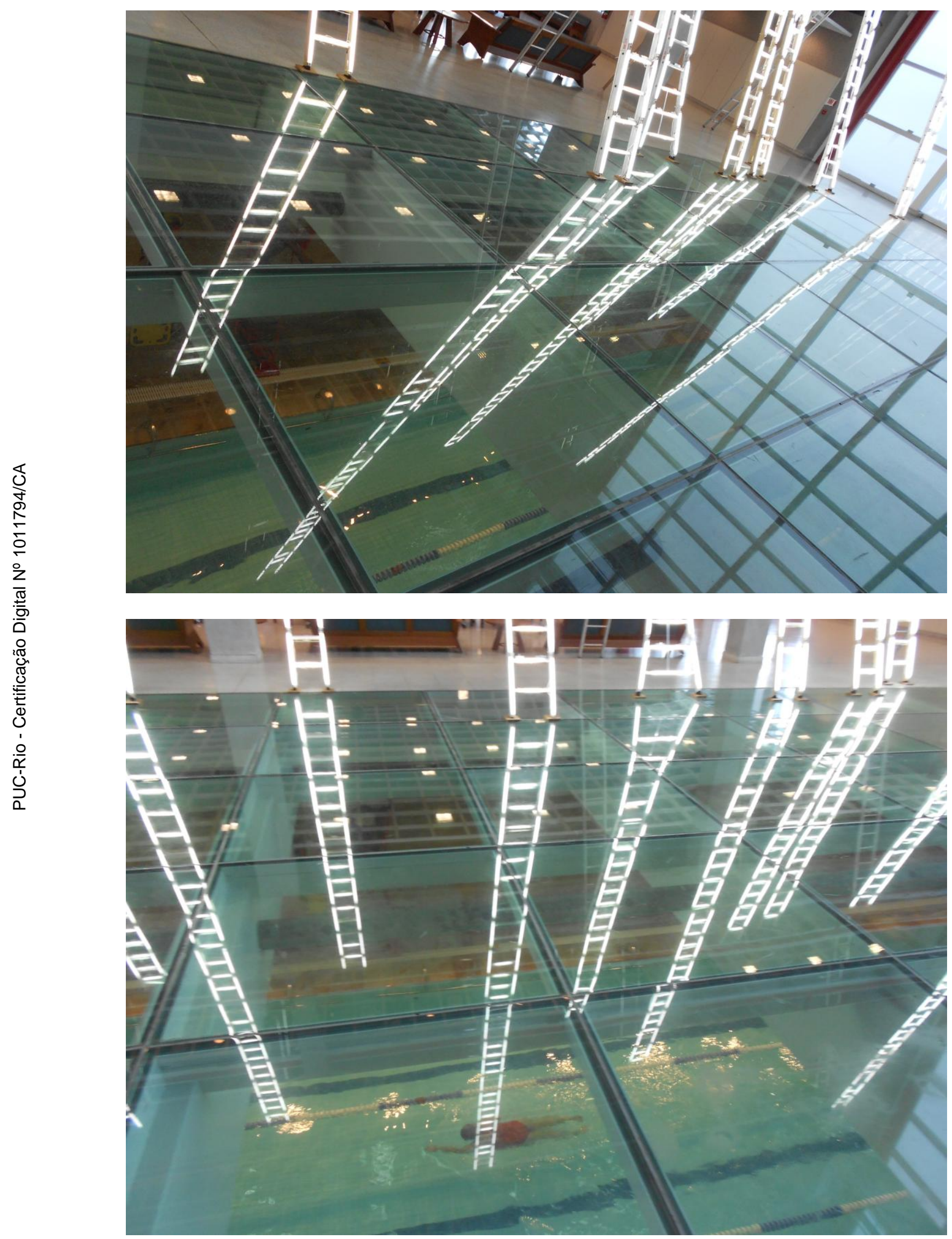




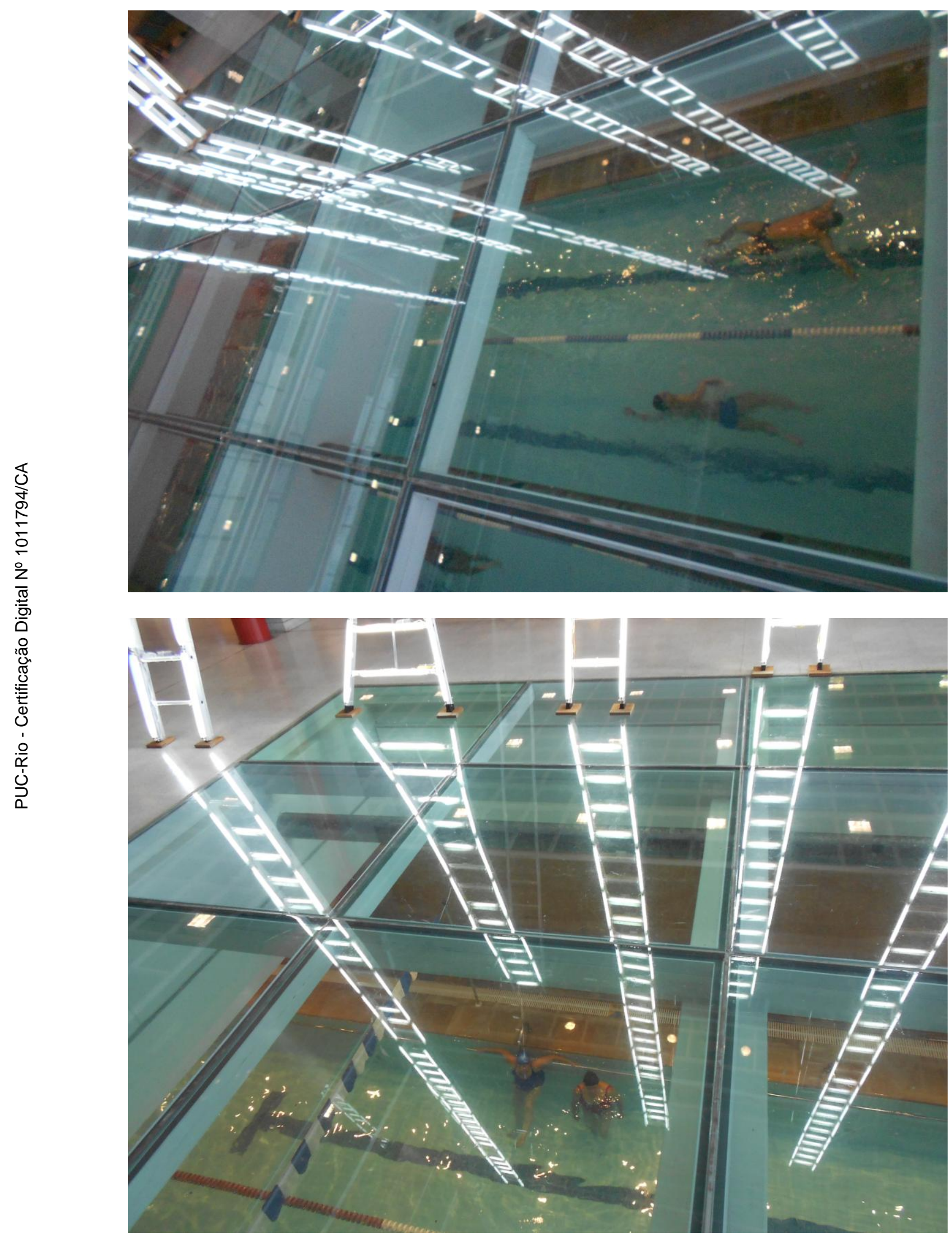




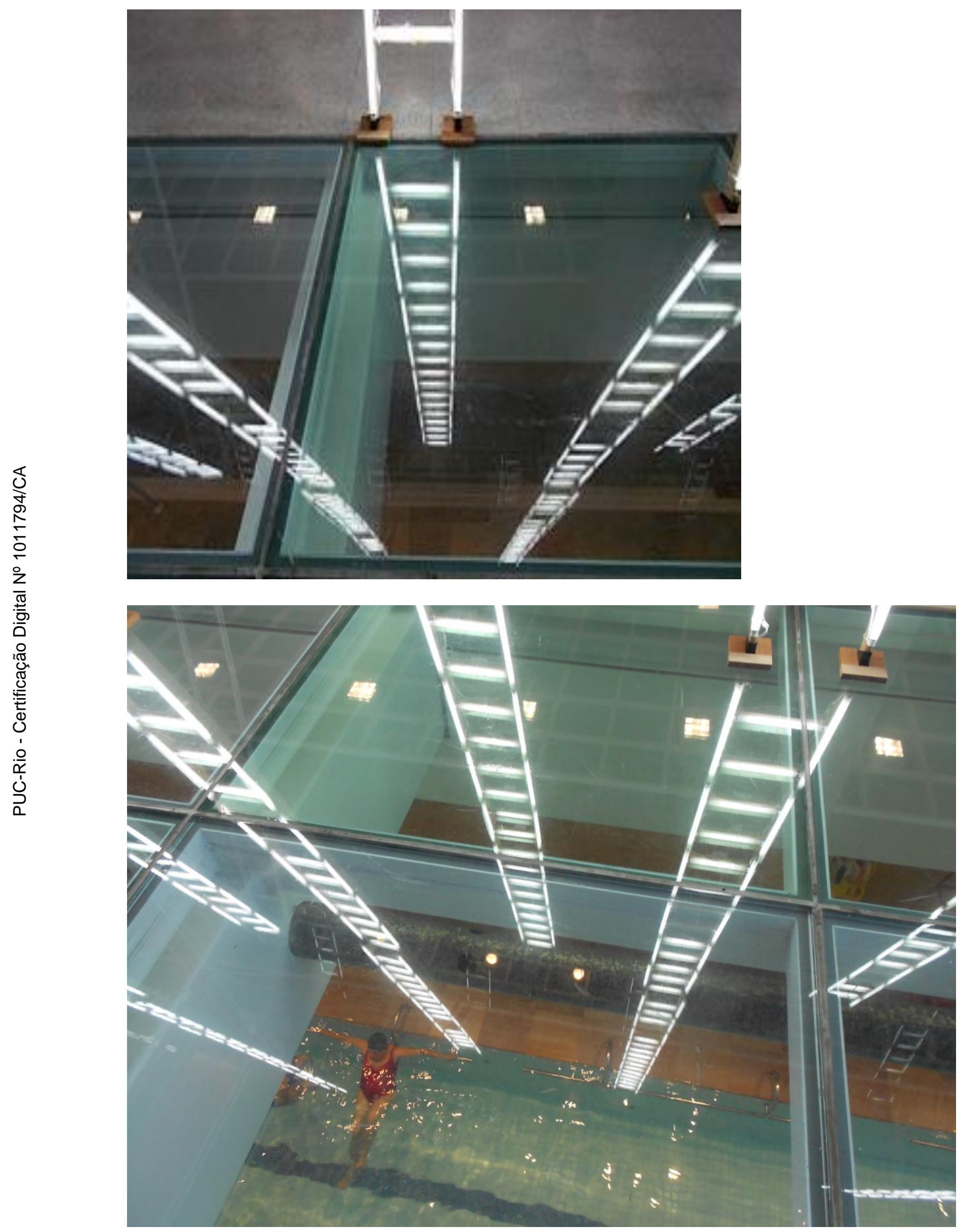




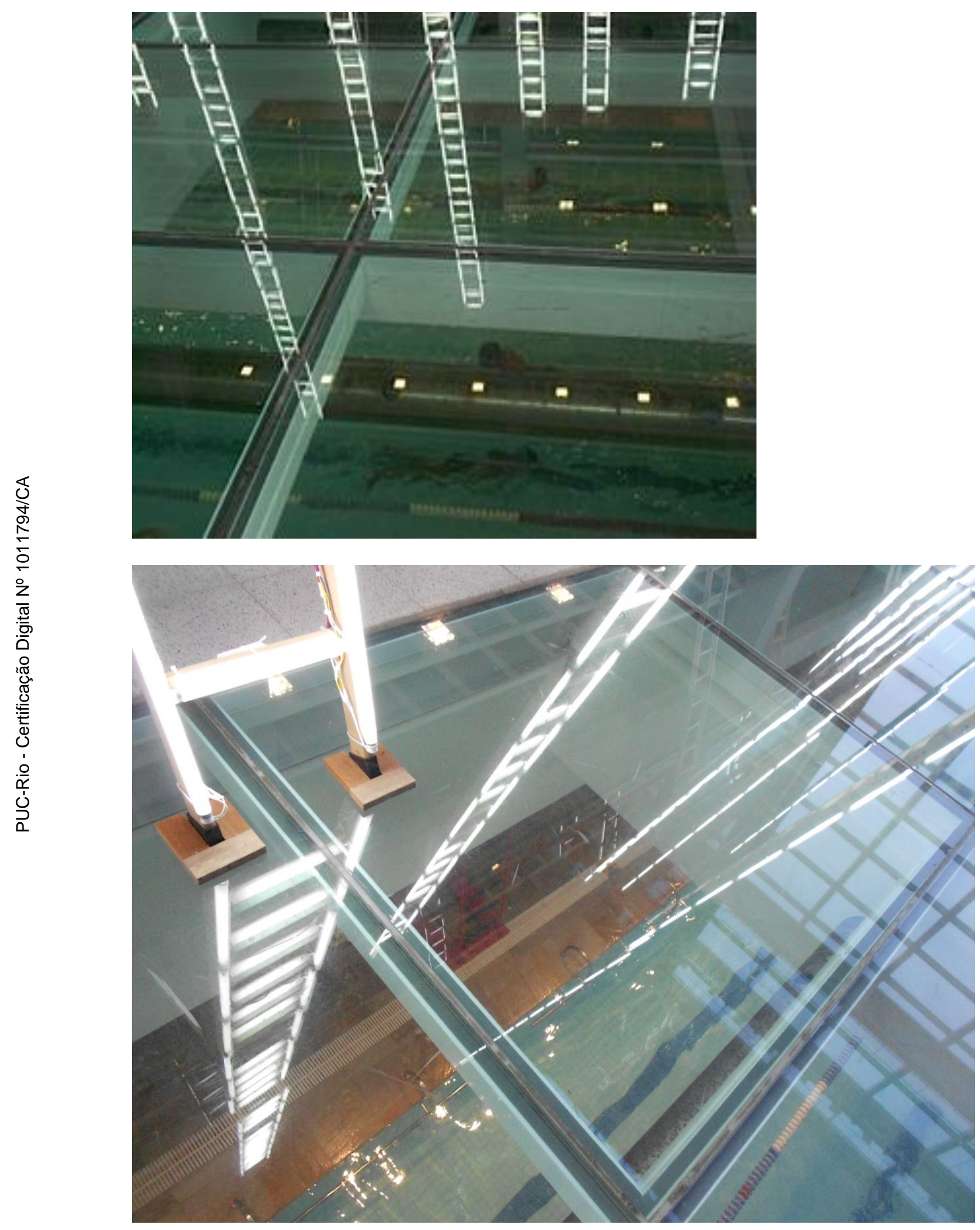




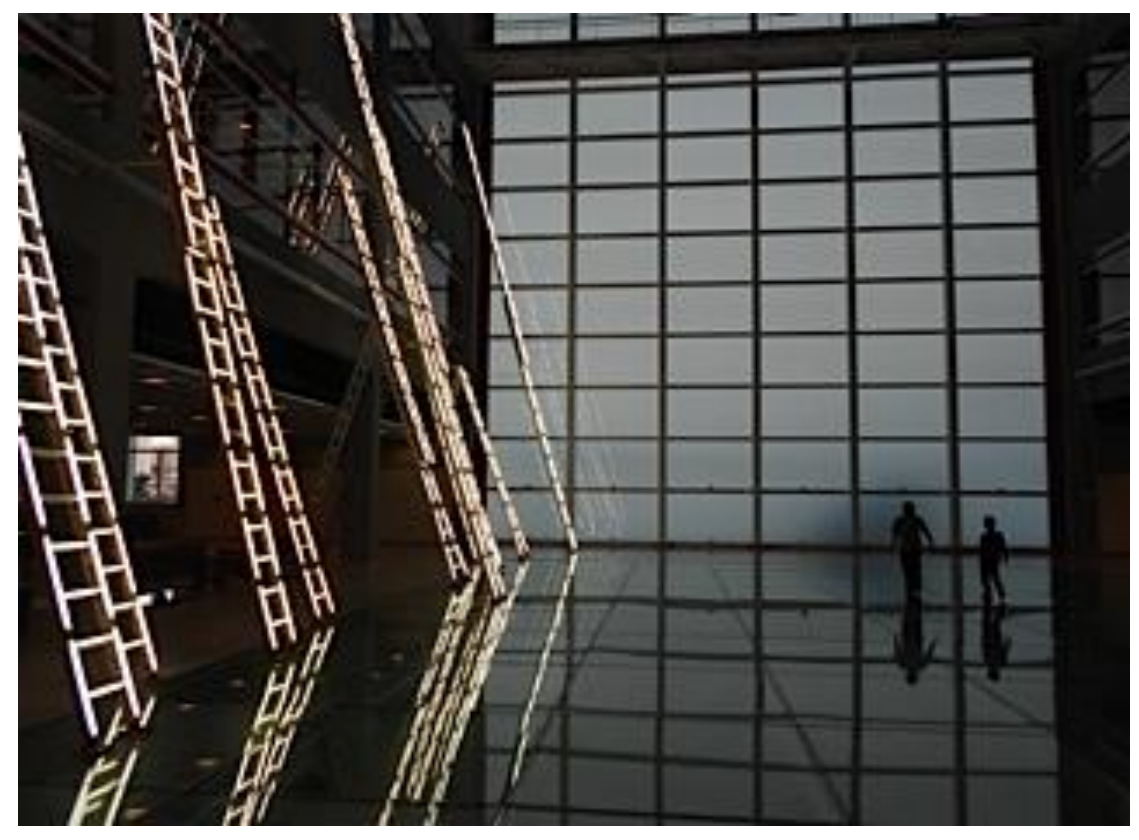

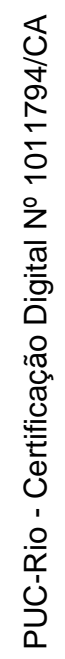

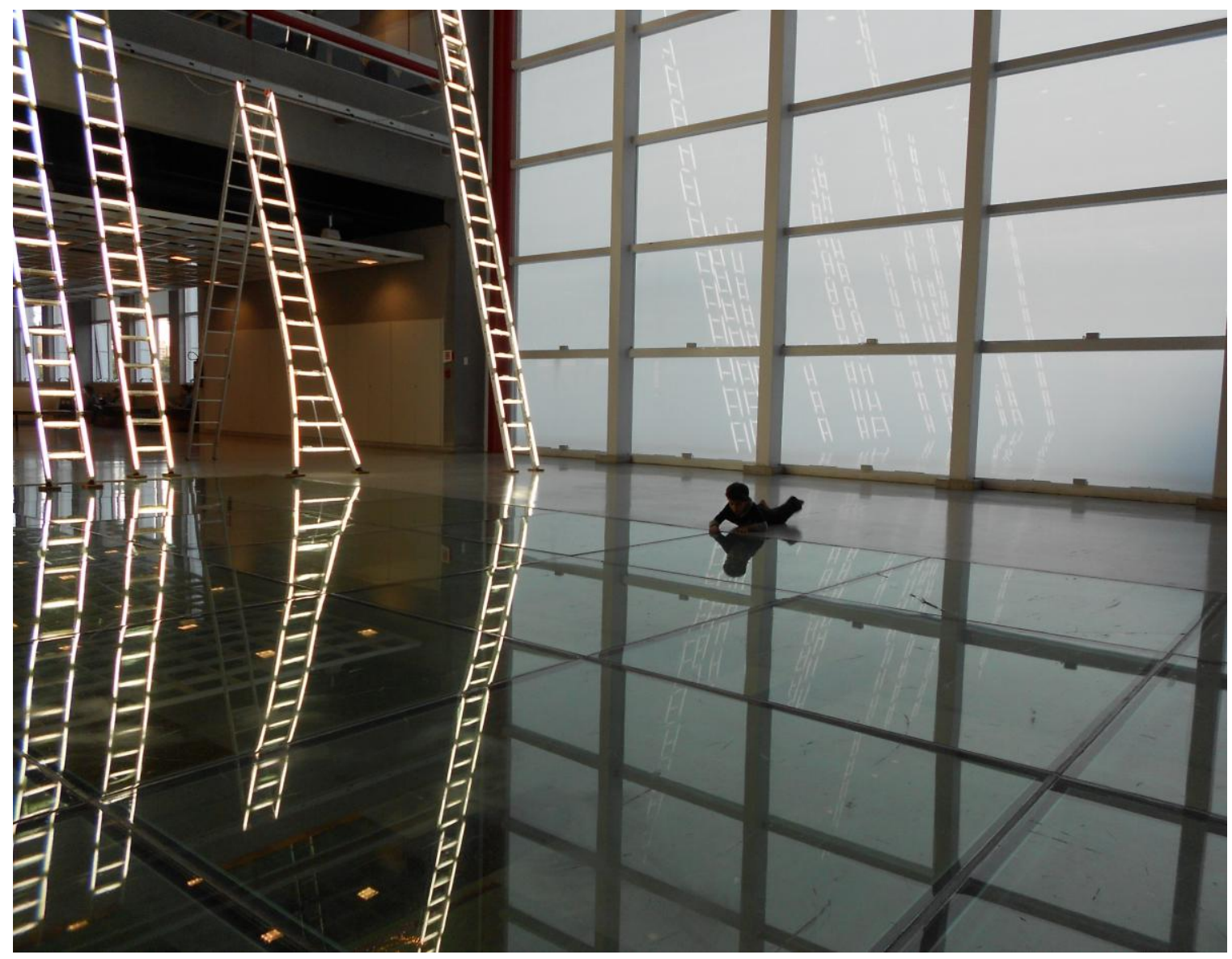




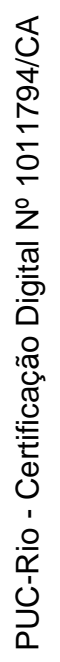
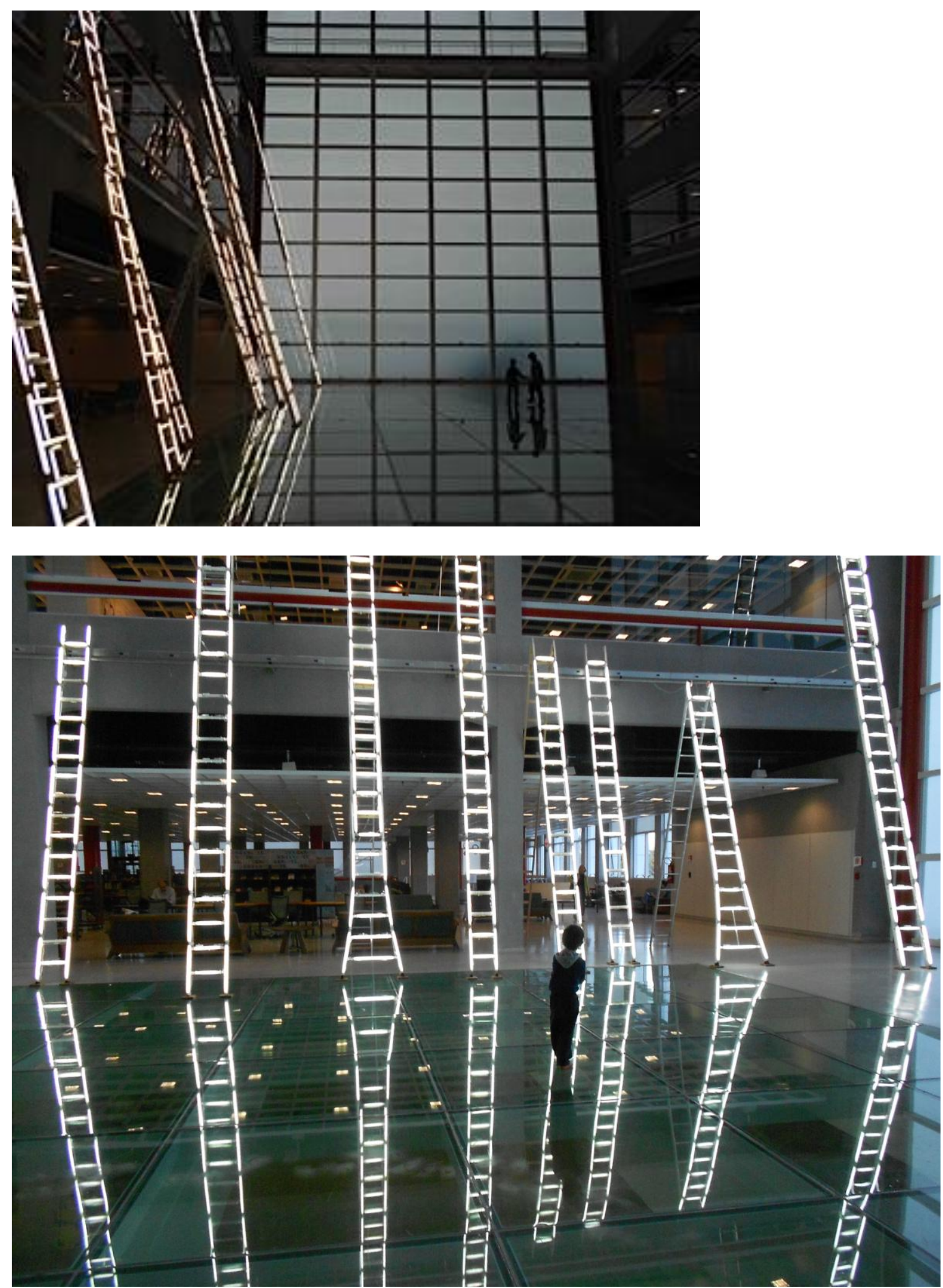


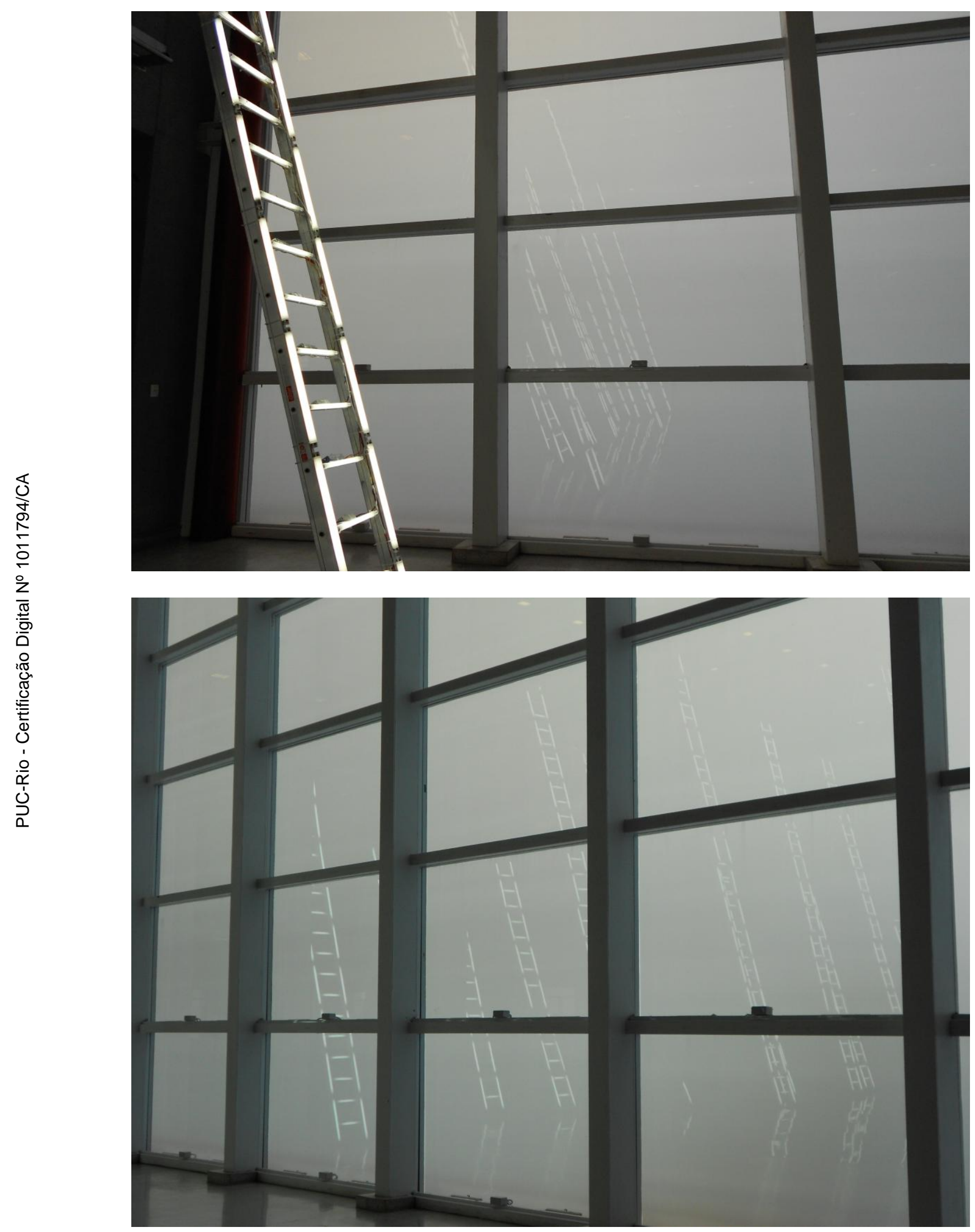





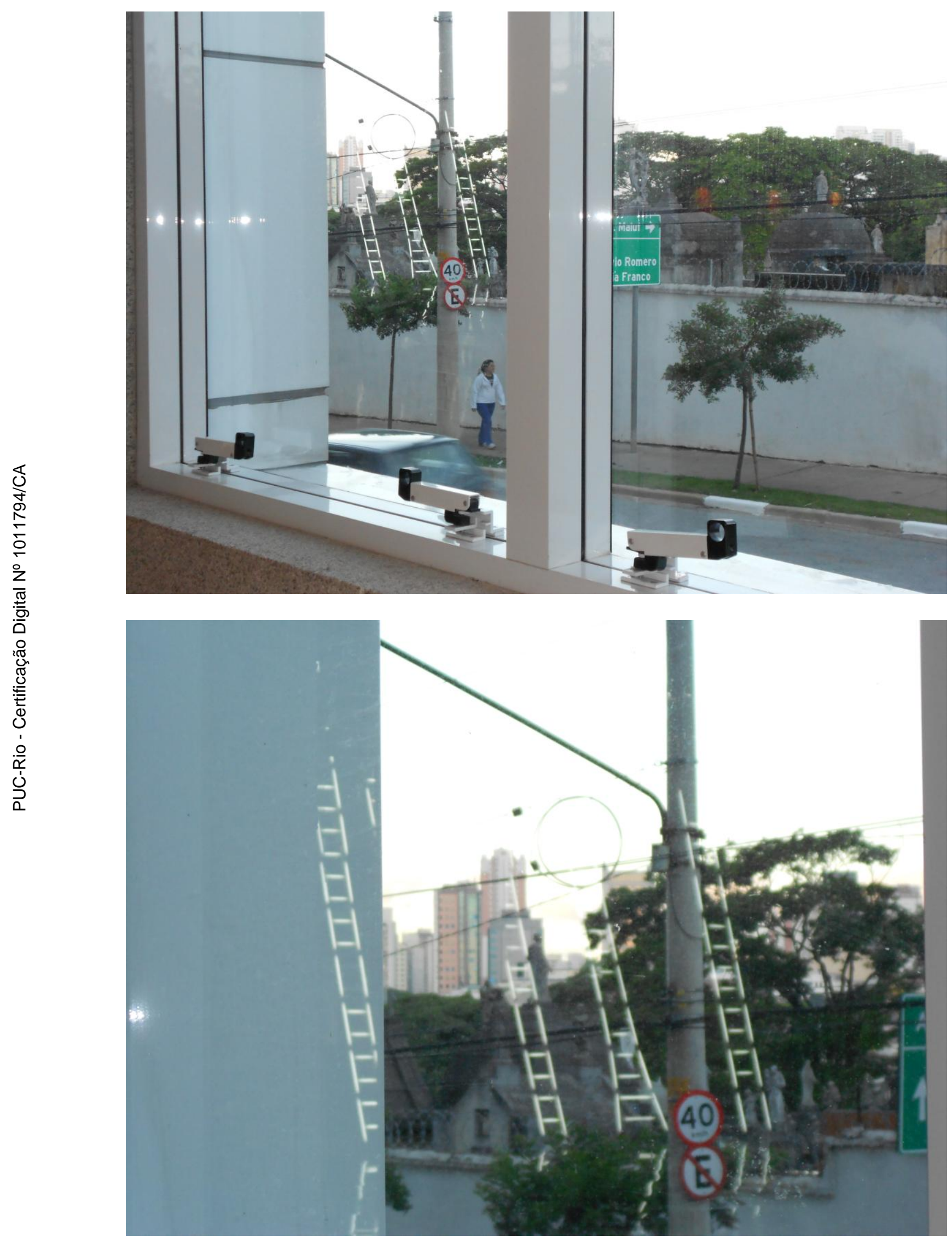

